\title{
Preparation of New Ru(II) Complexes Supported by Tetra(pyrazolyl)methane: Efforts toward $\mathrm{C}-\mathrm{H}$ Activation by Cationic Ru(II) Complexes
}

\author{
Chong Wang \\ Jinhua, China
}

B.S. Chemistry, Zhejiang University, 2009

A Thesis presented to the Graduate Faculty of the University of Virginia in Candidacy for the Degree of Master of Science

Department of Chemistry

University of Virginia

June, 2012

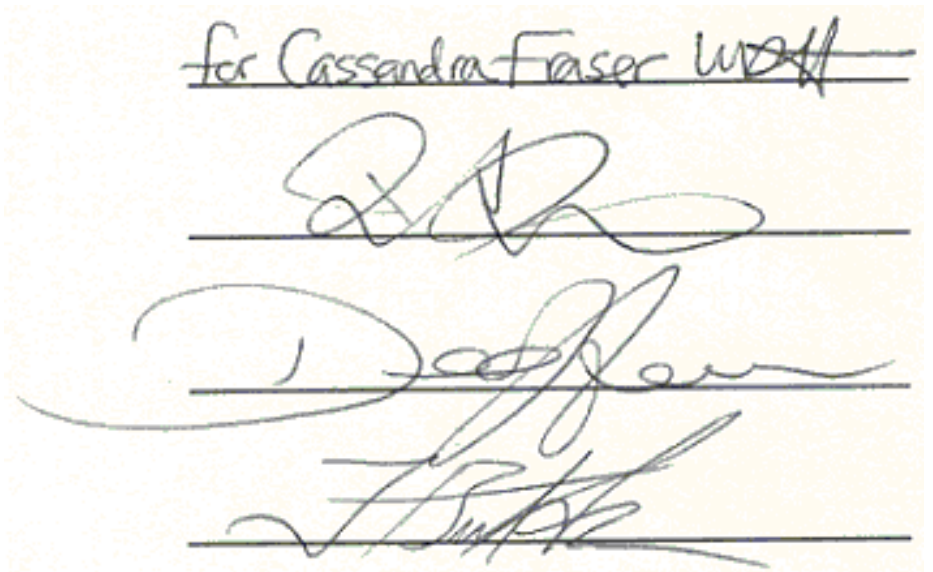




\begin{abstract}
Cheap and abundant natural gas provides a viable alternative to oil and coal with the opportunity to reduce $\mathrm{CO}_{2}$ emissions. Natural gas (primarily methane) is disadvantaged due to its low energy density and gaseous phase. Its broader use has been limited by safety and expense concerns associated with the transportation and storage of natural gas. As a result, the conversion of natural gas to liquid fuels (e.g., methanol) is of interest.

The conversion of hydrocarbons to functionalized products catalyzed by transition metal complexes has been studied. Our group previously reported that $\mathrm{TpRu}\left(\mathrm{PMe}_{3}\right)_{2} \mathrm{X}$ $(\mathrm{Tp}=$ hydridotris (pyrazolyl)borate $\mathrm{X}=\mathrm{NHPh}, \mathrm{OH}$ or $\mathrm{Me})$ can activate benzene $\mathrm{C}-\mathrm{H}$ bonds. However, studies of these reactions are complicated by the strongly coordinating $\mathrm{PMe}_{3}$ ligands, which must dissociate to coordinate benzene.

Presented here are the efforts to prepare $d^{6}$ charge neutral $\mathrm{Ru}(\mathrm{II})$ complexes $\left[\kappa^{3}-\right.$ $\left.\mathrm{C}(\mathrm{pz})_{4}\right] \mathrm{Ru}(\mathrm{L})(\mathrm{X})(\mathrm{Cl})\left[\mathrm{C}(\mathrm{pz})_{4}=\right.$ tetra(pyrazolyl)methane; $\left.\mathrm{X}=\mathrm{NHPh}, \mathrm{OH}, \mathrm{OMe}\right]$ and to exchange chloride with a non-coordinating anion to give the coordinatively unsaturated species $\left\{\left[\kappa^{3}-\mathrm{C}(\mathrm{pz})_{4}\right] \mathrm{Ru}(\mathrm{L})(\mathrm{X})\right\}^{+} .\left[\kappa^{3}-\mathrm{C}(\mathrm{pz})_{4}\right] \mathrm{Ru}(\mathrm{L})(\mathrm{X})(\mathrm{Cl})$ should provide more facile access to unsaturated reactive species than $\mathrm{TpRu}\left(\mathrm{PMe}_{3}\right)_{2} \mathrm{X}$. In addition, the cationic charge in $\left\{\left[\kappa^{3}-\mathrm{C}(\mathrm{pz})_{4}\right] \mathrm{Ru}(\mathrm{L})(\mathrm{X})\right\}^{+}$might facilitate $\mathrm{C}-\mathrm{H}$ activation. Currently, $\left\{\left[\kappa^{3}-\right.\right.$ $\left.\left.\mathrm{C}(\mathrm{pz})_{4}\right] \mathrm{Ru}(\mathrm{L})(\mathrm{XH})(\mathrm{Cl})\right\}^{+}\left(\mathrm{C}(\mathrm{pz})_{4}=\right.$ tetra(pyrazolyl)methane; $\mathrm{X}=\mathrm{NHPh}, \mathrm{OH}$ or $\mathrm{OMe} ; \mathrm{L}=$ $\left.\mathrm{P}\left(\mathrm{OCH}_{2}\right)_{3} \mathrm{CEt}\right)$ have been synthesized. The preparation and isolation of corresponding $\mathrm{Ru}-\mathrm{X}$ complexes was not successful due to fast decomposition after deprotonation. Further studies will focus on variation of ligands to stabilize $\mathrm{Ru}-\mathrm{X}$ complexes.
\end{abstract}




\section{Contents}

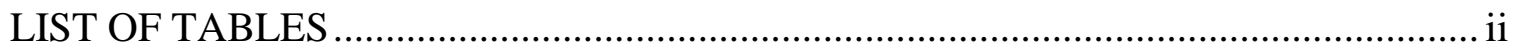

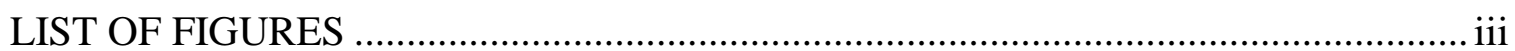

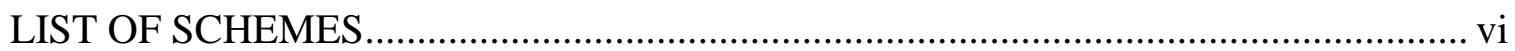

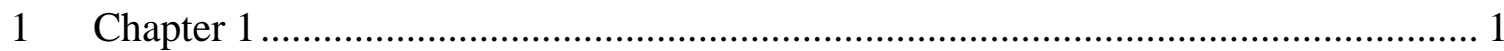

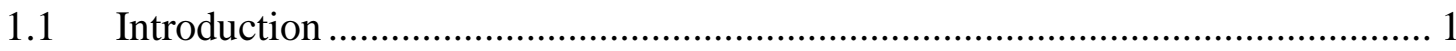

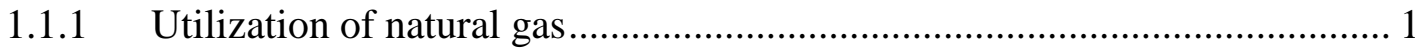

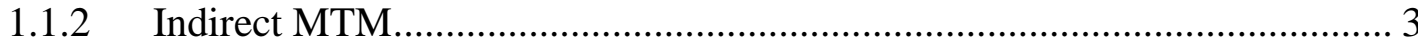

1.1.3 Non-metal-mediated hydrocarbon functionalization ............................... 4

1.1.4 Metal-mediated hydrocarbon functionalization ...................................... 5

1.1.5 Shilov system for hydrocarbon functionalization ............................... 13

1.1.6 Non-Shilov system for hydrocarbon functionalization ........................... 14

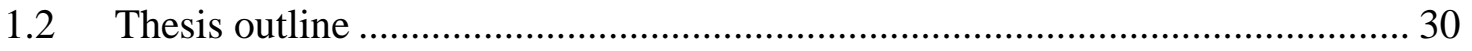

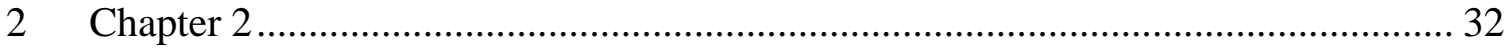

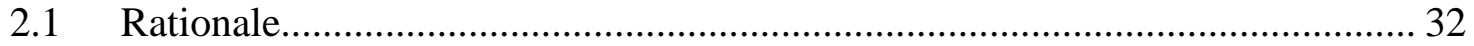

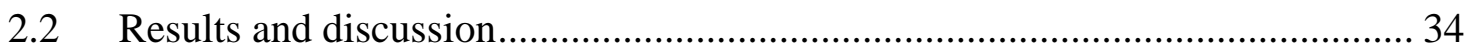

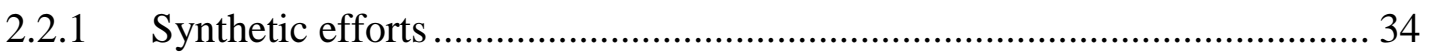

2.2.2 Synthesis and Reactivity of $\mathrm{Ru}(\mathrm{II})$-aniline complexes........................... 47

2.2.3 Efforts toward the synthesis of Ru(II)-anilido complexes ........................ 63

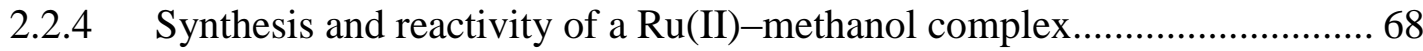

2.2.5 Attempts to synthesize a $\mathrm{Ru}(\mathrm{II})$-hydroxide complex ............................. 75

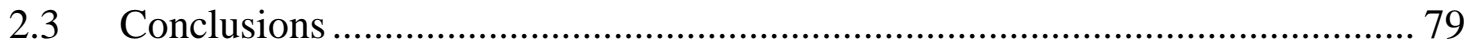

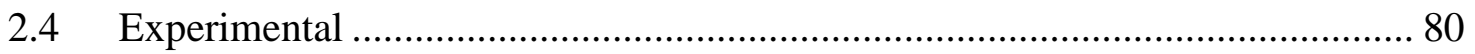

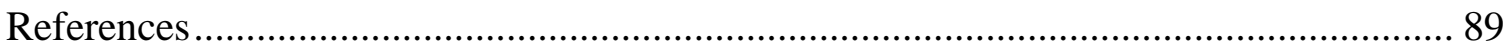




\section{LIST OF TABLES}

Table 2.1. Results of the deprotonation of $\mathrm{Ru}$-aniline complexes in different solvent/base

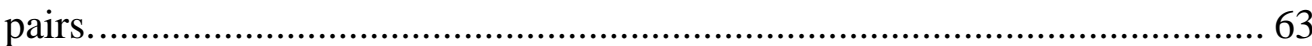

Table 2.2. Results of the deprotonation of complex $\mathbf{1 0}$ in methanol by different bases.. 74

Table 2.3. Results of deprotonation of complex 11 in different solvent/base pairs......... 78 


\section{LIST OF FIGURES}

Figure 2.1. ${ }^{1} \mathrm{H}$ NMR spectrum (downfield region) of $\left[\kappa^{3}-\mathrm{C}(\mathrm{pz})_{4}\right] \mathrm{RuCl}_{2}\left(\mathrm{PPh}_{3}\right)(2)$ in

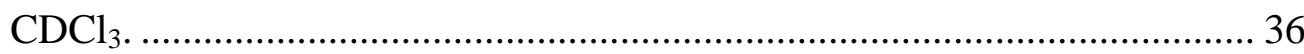

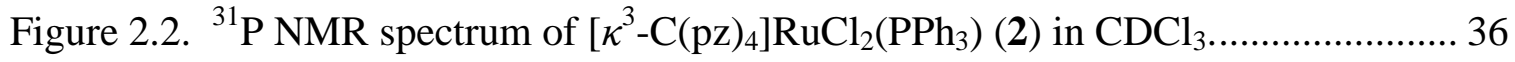

Figure 2.3. ${ }^{13} \mathrm{C} \mathrm{NMR}$ spectrum of $\left[\kappa^{3}-\mathrm{C}(\mathrm{pz})_{4}\right] \mathrm{RuCl}_{2}\left(\mathrm{PPh}_{3}\right)(2)$ in $\mathrm{CDCl}_{3} \ldots \ldots \ldots \ldots \ldots \ldots . . . . . . . . . . .37$

Figure 2.4. ${ }^{1} \mathrm{H}$ NMR spectrum of $\left[\kappa^{3}-\mathrm{C}(\mathrm{pz})_{4}\right] \mathrm{RuCl}_{2}\left[\mathrm{P}\left(\mathrm{OCH}_{2}\right)_{3} \mathrm{CEt}\right](3)$ in $\mathrm{CD}_{2} \mathrm{Cl}_{2} \ldots \ldots \ldots . .39$

Figure 2.5. ${ }^{31} \mathrm{P}$ NMR spectrum of $\left[\kappa^{3}-\mathrm{C}(\mathrm{pz})_{4}\right] \mathrm{RuCl}_{2}\left[\mathrm{P}\left(\mathrm{OCH}_{2}\right)_{3} \mathrm{CEt}\right](\mathbf{3})$ in $\mathrm{CD}_{2} \mathrm{Cl}_{2} \ldots \ldots .39$

Figure 2.6. ${ }^{13} \mathrm{C} N M R$ spectrum of $\left[\kappa^{3}-\mathrm{C}(\mathrm{pz})_{4}\right] \mathrm{RuCl}_{2}\left[\mathrm{P}\left(\mathrm{OCH}_{2}\right)_{3} \mathrm{CEt}\right](3)$ in $\mathrm{CD}_{3} \mathrm{NO}_{2} \ldots .40$

Figure 2.7. Comparison of ${ }^{1} \mathrm{H}$ NMR spectra of $\mathbf{3}$ (bottom) and 4 (top) in $\mathrm{CD}_{2} \mathrm{Cl}_{2} \ldots \ldots \ldots .44$

Figure 2.8. ${ }^{1} \mathrm{H} N M R$ spectrum of $\left\{\left[\kappa^{3}-\mathrm{C}(\mathrm{pz})_{4}\right] \mathrm{Ru}(\mu-\mathrm{Cl})\left[\mathrm{P}\left(\mathrm{OCH}_{2}\right)_{3} \mathrm{CEt}\right]\right\}_{2}\{\mathrm{OTf}\}_{2}(4)$ in

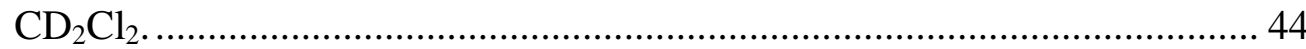

Figure 2.9. ${ }^{31} \mathrm{P}$ NMR spectrum of $\left\{\left[\kappa^{3}-\mathrm{C}(\mathrm{pz})_{4}\right] \mathrm{Ru}(\mu-\mathrm{Cl})\left[\mathrm{P}\left(\mathrm{OCH}_{2}\right)_{3} \mathrm{CEt}\right]\right\}_{2}\{\mathrm{OTf}\}_{2}(4)$ in

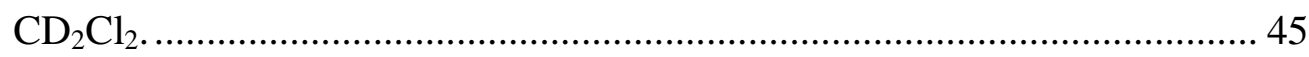

Figure 2.10. ${ }^{19} \mathrm{~F}$ NMR spectrum of $\left\{\left[\kappa^{3}-\mathrm{C}(\mathrm{pz})_{4}\right] \mathrm{Ru}(\mu-\mathrm{Cl})\left[\mathrm{P}\left(\mathrm{OCH}_{2}\right)_{3} \mathrm{CEt}\right]\right\}_{2}\{\mathrm{OTf}\}_{2}(4)$ in

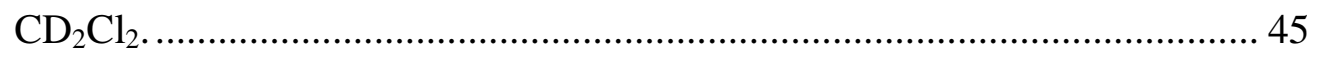

Figure 2.11. ${ }^{13} \mathrm{C}$ NMR spectrum of $\left\{\left[\kappa^{3}-\mathrm{C}(\mathrm{pz})_{4}\right] \mathrm{Ru}(\mu-\mathrm{Cl})\left[\mathrm{P}\left(\mathrm{OCH}_{2}\right)_{3} \mathrm{CEt}\right]\right\}_{2}\{\mathrm{OTf}\}_{2}(4)$ in

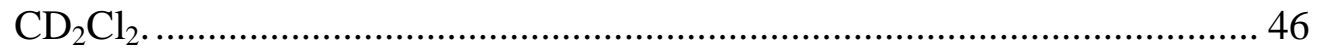

Figure 2.12. ${ }^{31} \mathrm{P}$ NMR spectra of dimer 4 in $\mathrm{CD}_{2} \mathrm{Cl}_{2}$ : before addition of $\mathrm{PMe}_{3}$ (bottom) and after addition of $\mathrm{PMe}_{3}$ (top).

Figure 2.13. ${ }^{1} \mathrm{H}$ NMR spectrum of $\left\{\left[\kappa^{3}-\mathrm{C}(\mathrm{pz})_{4}\right] \mathrm{Ru}\left[\mathrm{P}\left(\mathrm{OCH}_{2}\right)_{3} \mathrm{CEt}\right](\mathrm{Cl})\left(\mathrm{NH}_{2} \mathrm{Ph}\right)\right\}\{\mathrm{OTf}\}(\mathbf{5})$ in $\mathrm{CD}_{2} \mathrm{Cl}_{2}$

Figure 2.14. ${ }^{1} \mathrm{H}$ gCOSY spectrum of $\left\{\left[\kappa^{3}-\mathrm{C}(\mathrm{pz})_{4}\right] \mathrm{Ru}\left[\mathrm{P}\left(\mathrm{OCH}_{2}\right)_{3} \mathrm{CEt}\right](\mathrm{Cl})\left(\mathrm{NH}_{2} \mathrm{Ph}\right)\right\}\{\mathrm{OTf}\}$ (5) in $\mathrm{CD}_{2} \mathrm{Cl}_{2}$. 49

Figure 2.15. ${ }^{19} \mathrm{~F}$ NMR spectrum of $\left\{\left[\kappa^{3}-\mathrm{C}(\mathrm{pz})_{4}\right] \mathrm{Ru}\left[\mathrm{P}\left(\mathrm{OCH}_{2}\right)_{3} \mathrm{CEt}\right](\mathrm{Cl})\left(\mathrm{NH}_{2} \mathrm{Ph}\right)\right\}\{\mathrm{OTf}\}(\mathbf{5})$ in $\mathrm{CD}_{2} \mathrm{Cl}_{2}$.

Figure 2.16. ${ }^{31} \mathrm{P} N M R$ spectrum of $\left\{\left[\kappa^{3}-\mathrm{C}(\mathrm{pz})_{4}\right] \mathrm{Ru}\left[\mathrm{P}\left(\mathrm{OCH}_{2}\right)_{3} \mathrm{CEt}\right](\mathrm{Cl})\left(\mathrm{NH}_{2} \mathrm{Ph}\right)\right\}\{\mathrm{OTf}\}(\mathbf{5})$ in $\mathrm{CD}_{2} \mathrm{Cl}_{2}$. 
Figure 2.17. ${ }^{13} \mathrm{C}$ NMR spectrum of $\left\{\left[\kappa^{3}-\mathrm{C}(\mathrm{pz})_{4}\right] \mathrm{Ru}\left[\mathrm{P}\left(\mathrm{OCH}_{2}\right)_{3} \mathrm{CEt}\right](\mathrm{Cl})\left(\mathrm{NH}_{2} \mathrm{Ph}\right)\right\}\{\mathrm{OTf}\}$

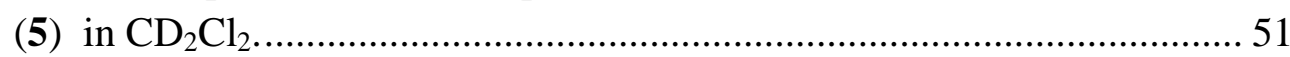

Figure 2.18. Different splitting patterns in ${ }^{1} \mathrm{H}$ NMR spectra of complex 5 in $\mathrm{CD}_{2} \mathrm{Cl}_{2}$ : before (bottom) and after (top) introducing ${ }^{15} \mathrm{NH}_{2} \mathrm{Ph}$. 52

Figure 2.19. ${ }^{1} \mathrm{H}$ gCOSY spectrum of $\left\{\left[\kappa^{3}-\mathrm{C}(\mathrm{pz})_{4}\right] \mathrm{Ru}\left[\mathrm{P}\left(\mathrm{OCH}_{2}\right)_{3} \mathrm{CEt}\right](\mathrm{Cl})\left({ }^{15} \mathrm{NH}_{2} \mathrm{Ph}\right)\right\}\{\mathrm{OTf}\}$ $\left({ }^{15} \mathrm{~N}-5\right)$ in $\mathrm{CD}_{2} \mathrm{Cl}_{2}$. 53

Figure 2.20. ${ }^{19} \mathrm{~F}$ NMR spectra of complex 5 (bottom) and complex $\mathbf{6}$ (top) in $\mathrm{CDCl}_{3} \ldots .55$

Figure 2.21. ${ }^{1} \mathrm{H}$ NMR spectrum of $\left\{\left[\kappa^{3}-\mathrm{C}(\mathrm{pz})_{4}\right] \mathrm{Ru}\left[\mathrm{P}\left(\mathrm{OCH}_{2}\right)_{3} \mathrm{CEt}\right](\mathrm{Cl})\left(\mathrm{NH}_{2} \mathrm{Ph}\right)\right\}\left\{\mathrm{BAr}_{4}{ }^{\prime}\right\}$

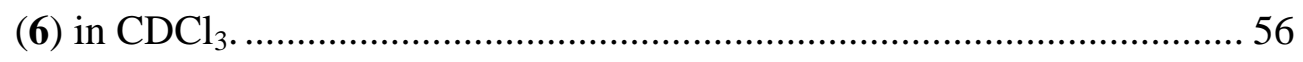

Figure 2.22. ${ }^{1} \mathrm{H}$ gCOSY spectrum of $\left\{\left[\kappa^{3}-\right.\right.$ $\left.\left.\mathrm{C}(\mathrm{pz})_{4}\right] \mathrm{Ru}\left[\mathrm{P}\left(\mathrm{OCH}_{2}\right)_{3} \mathrm{CEt}\right](\mathrm{Cl})\left(\mathrm{NH}_{2} \mathrm{Ph}\right)\right\}\left\{\mathrm{BAr}^{\prime}{ }_{4}\right\}(\mathbf{6})$ in $\mathrm{CDCl}_{3}$ 56

Figure 2.23. Different splitting patters in the ${ }^{1} \mathrm{H}$ NMR spectra of complex 6 in THF- $d_{8}$ : before (bottom) and after (top) introducing ${ }^{15} \mathrm{NH}_{2} \mathrm{Ph}$. 57

Figure 2.24. ${ }^{31} \mathrm{P}$ NMR spectrum of complex 6 in $\mathrm{THF}-d_{8}$. 57

Figure 2.25. ${ }^{13} \mathrm{C}$ NMR spectrum of $\left\{\left[\kappa^{3}-\mathrm{C}(\mathrm{pz})_{4}\right] \mathrm{Ru}\left[\mathrm{P}\left(\mathrm{OCH}_{2}\right)_{3} \mathrm{CEt}\right](\mathrm{Cl})\left(\mathrm{NH}_{2} \mathrm{Ph}\right)\right\}\left\{\mathrm{BAr}_{4}{ }^{\prime}\right\}$

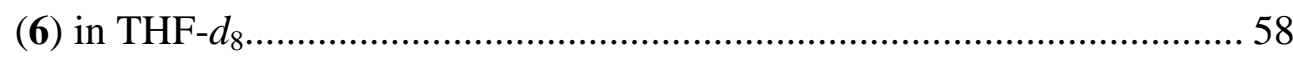

Figure 2.26. ${ }^{1} \mathrm{H} N M R$ spectrum of $\left\{\left[\kappa^{3}-\mathrm{C}(\mathrm{pz})_{4}\right] \mathrm{Ru}\left[\mathrm{P}\left(\mathrm{OCH}_{2}\right)_{3} \mathrm{CEt}\right]\left(\mathrm{PhNH}_{2}\right)_{2}\right\}\{\mathrm{OTf}\}_{2}(7)$ in $\mathrm{CD}_{2} \mathrm{Cl}_{2}$. 60

Figure 2.27. ${ }^{1} \mathrm{H}$ gCOSY spectrum of complex 7 in $\mathrm{CD}_{2} \mathrm{Cl}_{2}$. 60

Figure 2.28. ${ }^{19} \mathrm{~F}$ NMR spectrum of $\left\{\left[\kappa^{3}-\mathrm{C}(\mathrm{pz})_{4}\right] \mathrm{Ru}\left\{\mathrm{P}\left(\mathrm{OCH}_{2}\right)_{3} \mathrm{CEt}\right\}\left(\mathrm{PhNH}_{2}\right)_{2}\right\}\{\mathrm{OTf}\}_{2}(\mathbf{7})$ in $\mathrm{CD}_{2} \mathrm{Cl}_{2}$. 61

Figure 2.29. ${ }^{31} \mathrm{P}$ NMR spectrum of $\left\{\left[\kappa^{3}-\mathrm{C}(\mathrm{pz})_{4}\right] \mathrm{Ru}\left\{\mathrm{P}\left(\mathrm{OCH}_{2}\right)_{3} \mathrm{CEt}\right\}\left(\mathrm{PhNH}_{2}\right)_{2}\right\}\{\mathrm{OTf}\}_{2}(7)$ in $\mathrm{CD}_{3} \mathrm{CN}$. 61

Figure 2.30. ${ }^{13} \mathrm{C}$ NMR spectrum of $\left\{\left[\kappa^{3}-\mathrm{C}(\mathrm{pz})_{4}\right] \mathrm{Ru}\left\{\mathrm{P}\left(\mathrm{OCH}_{2}\right)_{3} \mathrm{CEt}\right\}\left(\mathrm{PhNH}_{2}\right)_{2}\right\}\{\mathrm{OTf}\}_{2}(7)$ in $\mathrm{CD}_{3} \mathrm{CN}$.

Figure 2.31. Comparison of the ${ }^{1} \mathrm{H}$ NMR spectra of complex 6 and in-situ generation of complex 8 in THF- $d_{8}$ : before (bottom) and after (top) addition of base...... 64

Figure 2.32. Variable temperature study of complex $\mathbf{8}$ in THF- $d_{8}$ : the resonance for the anilido proton shifts downfield with decreasing temperature. 65 
Figure 2.33. Variable temperature study of complex $8-{ }^{15} \mathrm{~N}$ in THF- $d_{8}$ : the $\operatorname{doublet}\left({ }^{1} J_{\mathrm{NH}}=\right.$ $80 \mathrm{~Hz}$ ) for the anilido proton shifts downfield with decreasing temperature.

Figure 2.34. Comparison of the ${ }^{1} \mathrm{H}$ NMR spectra of complex 7 and in-situ generation of complex 9 in methylene chloride- $d_{2}$ : before (bottom) and after (top) addition of base.

Figure 2.35. ${ }^{1} \mathrm{H}$ NMR spectrum of complex $\mathbf{1 0}$ in methanol- $d_{4}$. Complex 10 was synthesized in $\mathrm{CH}_{3} \mathrm{OH}$.

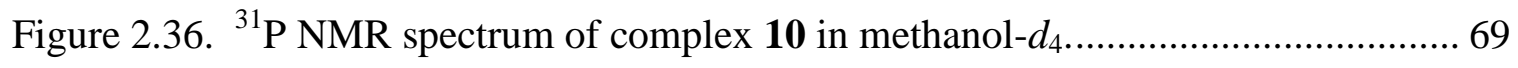

Figure 2.37. Comparison of the ${ }^{1} \mathrm{H}$ NMR spectra of complex $\mathbf{1 0}$ (bottom) and 10- $d_{8}$ (top) in methanol- $d_{4}$. 71

Figure 2.38. ${ }^{1} \mathrm{H}$ NMR spectrum of complex $\mathbf{1 0}$ in methanol- $d_{4}$ : the integration is different from 3:1 due to the H/D exchange on the methanol ligands. 72

Figure 2.39. ${ }^{1}$ H NMR spectra of complex 10- $d_{8}$ : before (bottom) and after (top) H/D exchange with protio methanol................................................................ 73

Figure 2.40. ${ }^{1} \mathrm{H}$ NMR spectrum of in-situ generation of complex 11 in THF- $d_{8} \ldots \ldots \ldots . . . .77$

Figure 2.41. ${ }^{1} \mathrm{H}$ NMR spectrum of in-situ generation of complex 11 in acetone- $d_{6} \ldots \ldots . .77$ 


\section{LIST OF SCHEMES}

Scheme 1.1. Indirect conversion of methane-to-methanol via synthesis gas. 3

Scheme 1.2. An indirect approach for partial oxidation of methane to methanol catalyzed by iodine cations.

Scheme 1.3. A direct approach for partial oxidation of methane via a radical reaction using $\mathrm{SO}_{3}$ as the oxidant. ................................................................. 5

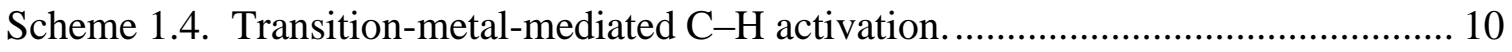

Scheme 1.5. Different pathways of $\mathrm{C}-\mathrm{H}$ bond cleavage by transition metal complexes

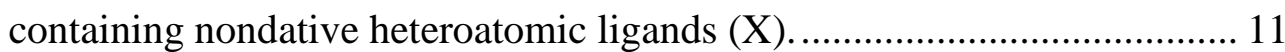

Scheme 1.6. Three predominant mechanisms of $\mathrm{C}-\mathrm{H}$ bond activation via 1,2-addition pathway: (a) oxidative addition; (b) electrophilic substitution; (c) $\sigma$-bond metathesis.

Scheme 1.7. Shilov system: stoichiometric use of Pt(IV) salts as oxidant for producing nucleophilic alkyl ligands.

Scheme 1.8. Catalytic cycle for hydrocarbon functionalization via 1,2-addition pathway.

Scheme 1.9. $\mathrm{C}-\mathrm{H}$ activation using early transition metal-imido complexes................. 15

Scheme 1.10. $\mathrm{C}-\mathrm{H} / \mathrm{H}-\mathrm{H}$ activation via transient $\left(t-\mathrm{Bu}_{3} \mathrm{SiNH}\right)_{2} \mathrm{Zr}=\mathrm{NSi} t-\mathrm{Bu}_{3} \ldots \ldots \ldots \ldots \ldots . . . . . .15$

Scheme 1.11. $\pi$-Conflict in high $d$-electron count late(r) transition metal complexes. ... 17

Scheme 1.12. Dihydrogen activation and intramolecular $\mathrm{C}-\mathrm{H}$ activation by coordinatively unsaturated $(\mathrm{PCP}) \mathrm{Ru}(\mathrm{CO})(\mathrm{X})\left(\mathrm{X}=\mathrm{NH}_{2}\right.$ or $\left.\mathrm{CH}_{3}\right)$

Scheme 1.13. DFT calculations (B3LYP/SBK(d)) for the activation of dihydrogen and methane by $(\mathrm{PCP}) \mathrm{Ru}(\mathrm{CO})\left(\mathrm{NH}_{2}\right)$.

Scheme 1.14. Dihydrogen activation by ( ${ }^{t}$ bpy) $\mathrm{Pt}(\mathrm{Me})(\mathrm{NHPh})$ and $(\mathrm{PCP}) \mathrm{Pd}(\mathrm{OR})(\mathrm{R}=\mathrm{H}$

or $\left.\mathrm{CH}_{3}\right)$. 21

Scheme 1.15. $\mathrm{H} / \mathrm{D}$ exchange between $\mathrm{TpRu}\left(\mathrm{PMe}_{3}\right)_{2}(\mathrm{XH})$ and $\mathrm{C}_{6} \mathrm{D}_{6}$. 22 
Scheme 1.16. Proposed catalytic pathway for $\mathrm{H} / \mathrm{D}$ exchange between $\mathrm{TpRu}\left(\mathrm{PMe}_{3}\right)_{2}(\mathrm{OH})$ and benzene- $d_{6}$.

Scheme 1.17. Metric data $(\AA)$ for calculated transition states of benzene $\mathrm{C}-\mathrm{H}$ activation by $(\mathrm{Tab}) \mathrm{Ru}\left(\mathrm{PH}_{3}\right)(\mathrm{OH})\left(\eta^{2}-\mathrm{C}_{6} \mathrm{H}_{6}\right)$ and $(\mathrm{Tab}) \mathrm{Ru}(\mathrm{CO})(\mathrm{Me})\left(\eta^{2}-\mathrm{C}_{6} \mathrm{H}_{6}\right) \ldots \ldots \ldots .24$

Scheme 1.18. Benzene C-H activation by O-donor Ir(III)-heteroatom complexes....... 26

Scheme 1.19. Proposed mechanism for benzene $\mathrm{C}-\mathrm{H}$ activation by (acac- $\mathrm{O}, \mathrm{O})_{2}{ }^{-}$

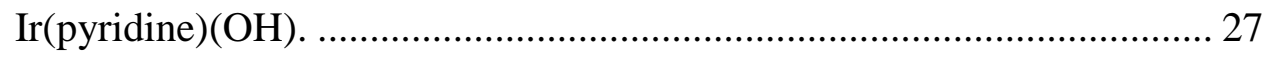

Scheme 1.20. General $\mathrm{C}-\mathrm{H}$ activation reaction profile via 1,2-addition across $\mathrm{M}-\mathrm{X}$ bond. 28

Scheme 1.21. Comparison of transition state structures for methane $\mathrm{C}-\mathrm{H}$ bond activation by $(\text { acac- } O, O)_{2} \mathrm{M}(\mathrm{Me})$ and $(\text { acac- } O, O)_{2} \mathrm{M}(\mathrm{OH})$. 29

Scheme 1.22. Two common reaction pathways for $\mathrm{M}-\mathrm{X}$ complexes with an open coordination site: dimerization and $\mathrm{C}-\mathrm{H}$ bond coordination.................. 31

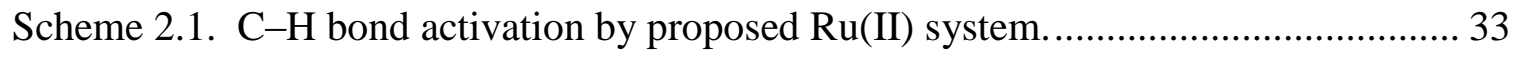

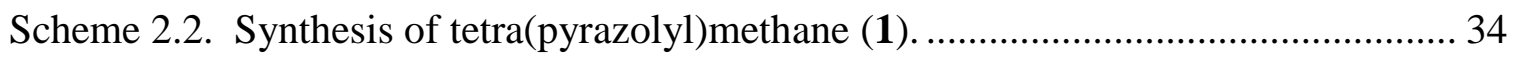

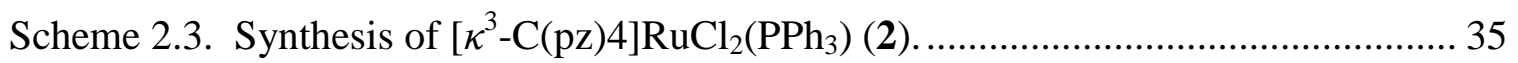

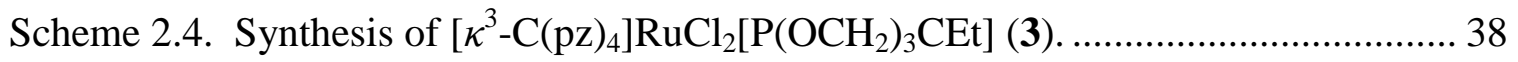

Scheme 2.5. Attempts to synthesize complexes possessing $\mathrm{M}-\mathrm{X}$ bonds from 3 .......... 41

Scheme 2.6. Attempts to synthesize $\mathrm{Ru}$-aniline and $\mathrm{Ru}$-methanol complexes from $3 \ldots 42$

Scheme 2.7. Attempts to synthesize complexes bearing aniline or methanol ligand from complex 3 by using labile triflate ligand............................................ 42

Scheme 2.8. Synthesis of $\left\{\left[\kappa^{3}-\mathrm{C}(\mathrm{pz})_{4}\right] \mathrm{Ru}(\mu-\mathrm{Cl})\left[\mathrm{P}\left(\mathrm{OCH}_{2}\right)_{3} \mathrm{CEt}\right]\right\}_{2}\{\mathrm{OTf}\}_{2}(4) \ldots \ldots \ldots \ldots . . . . . .43$

Scheme 2.9. Proposed dimer/monomer equilibrium solution of complex 4 in $\mathrm{CH}_{2} \mathrm{Cl}_{2}$ and reaction with $\mathrm{PMe}_{3}$ that confirms access to monomer. ......................... 47

Scheme 2.10. Synthesis of $\left\{\left[\kappa^{3}-\mathrm{C}(\mathrm{pz})_{4}\right] \mathrm{Ru}\left[\mathrm{P}\left(\mathrm{OCH}_{2}\right)_{3} \mathrm{CEt}\right](\mathrm{Cl})\left(\mathrm{NH}_{2} \mathrm{Ph}\right)\right\}\{\mathrm{OTf}\}(\mathbf{5}) \ldots \ldots . .48$

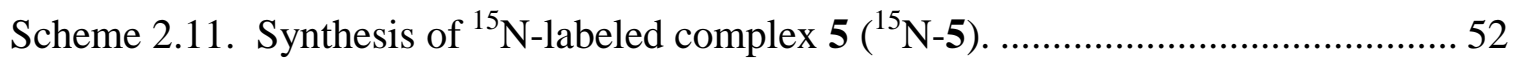


Scheme 2.12. Reversible Ru(III/II) potentials for complexes $\mathbf{3}$ and $\mathbf{5}$. Data from cyclic voltammetry in acetonitrile with reversible potentials $\left(\mathrm{E}_{1 / 2}\right)$ reported vs NHE.

Scheme 2.13. Synthesis of $\left\{\left[\kappa^{3}-\mathrm{C}(\mathrm{pz})_{4}\right] \mathrm{Ru}\left[\mathrm{P}\left(\mathrm{OCH}_{2}\right)_{3} \mathrm{CEt}\right](\mathrm{Cl})\left(\mathrm{NH}_{2} \mathrm{Ph}\right)\right\}\left(\mathrm{BAr}^{\prime}{ }_{4}\right)(\mathbf{6}) .55$

Scheme 2.14. Synthesis of $\left\{\left[\kappa^{3}-\mathrm{C}(\mathrm{pz})_{4}\right] \mathrm{Ru}\left[\mathrm{P}\left(\mathrm{OCH}_{2}\right)_{3} \mathrm{CEt}\right]\left(\mathrm{PhNH}_{2}\right)_{2}\right\}\{\mathrm{OTf}\}_{2}(7) \ldots \ldots . .59$

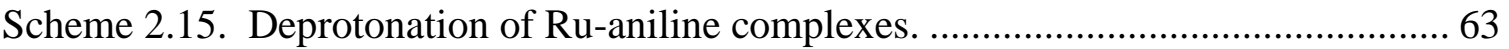

Scheme 2.16. Deprotonation of $\left\{\left[\kappa^{3}-\mathrm{C}(\mathrm{pz})_{4}\right] \mathrm{Ru}\left[\mathrm{P}\left(\mathrm{OCH}_{2}\right)_{3} \mathrm{CEt}\right]\left(\mathrm{PhNH}_{2}\right)_{2}\right\}\{\mathrm{OTf}\}_{2}(7) \ldots 66$

Scheme 2.17. Synthesis of $\left\{\left[\kappa^{3}-\mathrm{C}(\mathrm{pz})_{4} \mathrm{Ru}\left[\mathrm{P}\left(\mathrm{OCH}_{2}\right)_{3} \mathrm{CEt}\right]\left(\mathrm{CH}_{3} \mathrm{OH}\right)_{2}\right\}(\mathrm{OTf})_{2}(\mathbf{1 0}) \ldots \ldots . . .68\right.$

Scheme 2.18. Synthesis of $\left\{\left[\kappa^{3}-\mathrm{C}(\mathrm{pz})_{4} \mathrm{Ru}\left[\mathrm{P}\left(\mathrm{OCH}_{2}\right)_{3} \mathrm{CEt}\right]\left(\mathrm{CD}_{3} \mathrm{OD}\right)_{2}\right\}\{\mathrm{OTf}\}_{2}\left(\mathbf{1 0}-d_{8}\right) \ldots 70\right.$

Scheme 2.19. The $-\mathrm{OH} / \mathrm{D}$ exchange between complex $\mathbf{1 0}$ and free methanol............... 72

Scheme 2.20. In situ deprotonation of complex 10 results in decomposition. .............. 74

Scheme 2.21. Direct synthesis of Ru(II)-hydroxide complex was not successful due to decomposition....................................................................... 75

Scheme 2.22. Synthesis of $\left\{\left[\kappa^{3}-\mathrm{C}(\mathrm{pz})_{4}\right] \mathrm{Ru}\left[\mathrm{P}\left(\mathrm{OCH}_{2}\right)_{3} \mathrm{CEt}\right](\mathrm{Cl})\left(\mathrm{H}_{2} \mathrm{O}\right)\right\}\{\mathrm{OTf}\}(\mathbf{1 1}) \ldots \ldots . .76$

Scheme 2.23. In situ deprotonation of complex 11 results in decomposition. ............... 78 


\section{Chapter 1}

\subsection{Introduction}

\subsubsection{Utilization of natural gas}

Energy security is one of the most important issues to sustain our society. To meet increasing energy demands, new, cleaner resources including nuclear and solar power should be sought, but, in the immediate future, we will still likely rely on fossil fuels. Thus, developing new methods for more efficient utilization of fossil resources will continue to be important. Currently the predominant energy source is fossil fuels, with roughly equal parts from oil, coal and natural gas. ${ }^{1}$ Increased use of natural gas could lead to a reduction in oil and coal consumption and possible reduction in $\mathrm{CO}_{2}$ emission. Recent advances in technology to access natural gas have dramatically altered future scenarios for the U.S.'s energy portfolio.

Currently, natural gas is mainly used for power generation, residential use, and as an industrial feedstock. Natural gas is disadvantaged due to its low energy density and gaseous phase. Methane, the major component of natural gas ( $87 \%$ by volume), is highly flammable and difficult to compress (b.p. $-161.6{ }^{\circ} \mathrm{C}$ at $1 \mathrm{~atm}$ ). This presents two issues for scaled use of natural gas: 1) gas located at remote locations (e.g., Alaska's North Slope) cannot be easily transported; 2) scaled use of natural gas in the transportation's sector is not possible without expensive new infrastructure.

Liquefied natural gas (LNG) has been considered as a transportation fuel. ${ }^{2}$ Due to the operational and economical considerations, LNG is not an attractive option for the use of natural gas. Technologies to convert natural gas to liquid fuels in a low cost and selective 
manner could provide an attractive alternative to LNG and facilitate utilization on a larger scale. Selective conversion of natural gas to methanol or mid-range hydrocarbons are both options. In addition to the advantages of more facile transportation and storage, the conversion of methane-to-methanol (MTM) would also open a route for its broader use as a chemical feedstock, because methanol can be a precursor to ethylene and propylene for use in the chemical industry. Methanol can also help lessen the dependence on gasoline in the transportation sector. Currently, gasoline sold in most states contains up to $10 \%$ ethanol by volume and an increasing numbers of gas stations are supplying E85 (85\% ethanol/gasoline fuel blend). Gasoline engines can be modified to run on methanol-rich fuel at modest costs while maintaining $\mathrm{CO}_{2}$ emissions at the same or lower levels. In recent years, the price of oil has been at historically high levels, which stimulates the use of methanol in transportation as an alternative or supplement to gasoline. Also, much "stranded" natural gas could be used if viable conversion technology could be developed. Because of the abundant domestic supply of natural gas, such conversion offers an opportunity to reduce dependence on imported oil and strengthen national energy security. Thus, MTM conversion is of significant practical interest.

One strategy for MTM is transition metal mediated $\mathrm{C}-\mathrm{H}$ activation of methane coupled with $\mathrm{C}-\mathrm{O}$ bond formation. Our group has worked on developing new routes for $\mathrm{C}-\mathrm{H}$ activation that might be incorporated into catalytic cycles. My project is to develop new $\mathrm{Ru}(\mathrm{II})$ complexes with $\mathrm{Ru}-\mathrm{X}$ bonds (X $=\mathrm{OR}$ or NHR) supported by tetra(pyrazolyl)methane, and to pursue hydrocarbon $\mathrm{C}-\mathrm{H}$ activation with these complexes. 
This research is relevant to the development of selective, energy efficient catalysts for direct hydrocarbon partial oxidation.

\subsubsection{Indirect MTM}

Indirect MTM conversion via synthesis gas (syngas: $\mathrm{H}_{2}+\mathrm{CO}$ ), the Fischer-Tropsch process, is among the commercially practiced processes in industry (Scheme 1.1). This process requires high energy input $\left(\sim 900{ }^{\circ} \mathrm{C}, \sim 40 \mathrm{~atm}\right)$, which is not an ideal method for practical use. ${ }^{3}$ Thus, developing a catalyst for MTM at moderate conditions (ideally in a direct manner) has been a focus in recent years. ${ }^{4-9}$ One option is the direct partial oxidation of methane, using $\mathrm{O}_{2}$ as the ultimate oxidant, to methanol.

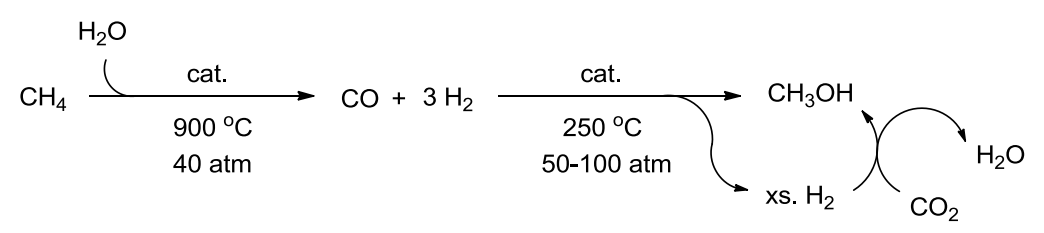

Scheme 1.1. Indirect conversion of methane-to-methanol via synthesis gas.

The direct MTM conversion requires cleavage of a $\mathrm{C}-\mathrm{H}$ bond of methane and formation of a $\mathrm{C}-\mathrm{O}$ bond. These two steps are termed $\mathrm{C}-\mathrm{H}$ activation and oxyfunctionalization, respectively. The large bond dissociation energies (BDEs) and covalent nature of $\mathrm{C}-\mathrm{H}$ bonds render them difficult to break. For example, the BDE of methane is $105 \mathrm{kcal} / \mathrm{mol} .{ }^{10}$ Additionally, $\mathrm{C}-\mathrm{H}$ bonds are covalent, which reduces susceptibility to attack by electrophiles or nucleophiles. To make the activation of a strong bond more kinetically accessible, an external bond is necessary to lower the activation barrier. Although hydrocarbons are chemically inert, a number of reactions of alkanes are known. 
These reactions can be divided into two main types: 1) transition metal-mediated processes and 2) non-metal-mediated processes.

\subsubsection{Non-metal-mediated hydrocarbon functionalization}

Transformations of alkanes without the participation of transition metal complexes are typically initiated by highly reactive species such as free radicals or carbenes. ${ }^{11-13}$ For example, heating alkanes at high temperature $\left(>900{ }^{\circ} \mathrm{C}\right)$ generates radicals and carbenes as intermediates, which will then produce multiple products. ${ }^{12}$ Attempts to carry out the partial oxidation of methane by radical reactions have also been reported with limited success. $^{14-19}$

$$
\mathrm{CH}_{4}+\mathrm{SO}_{3} \frac{\mathrm{I}_{2}^{+} \mathrm{HS}_{2} \mathrm{O}_{7}^{-}}{\mathrm{H}_{2} \mathrm{SO}_{4} / \mathrm{SO}_{3}} \mathrm{CH}_{3} \mathrm{OSO}_{3} \mathrm{H}+\mathrm{SO}_{2} \stackrel{\mathrm{H}_{2} \mathrm{O}}{\longrightarrow} \mathrm{CH}_{3} \mathrm{OH}+\mathrm{H}_{2} \mathrm{SO}_{4}
$$

Scheme 1.2. An indirect approach for partial oxidation of methane to methanol catalyzed by iodine cations.

Periana et al. reported an indirect approach for the partial oxidation of methane to methanol, in which methane can be converted to methyl bisulfate in a single-step process catalyzed by $\mathrm{I}_{2}{ }^{+}$(Scheme 1.2). ${ }^{20}$ The reaction is carried out in fuming sulfuric acid at $180-220{ }^{\circ} \mathrm{C}$ in up to $43 \%$ yield based on methane. Methyl bisulfate cannot be readily separated from sulfuric acid, so it is hydrolyzed to methanol by addition of water to the sulfuric acid solution. However, separation of methanol from the resulting solution is difficult, and the dilute sulfuric acid solution must be concentrated before it can be recycled. $^{21}$

Bell and co-workers also reported systems that are able to convert methane to partial oxidation products (e.g., acetic acid, methanol). ${ }^{15,21}$ A direct approach for partial 
oxidation of methane to methanol is demonstrated in a three-step, liquid phase process using $\mathrm{SO}_{3}$ as the oxidant (Scheme 1.3). ${ }^{21}$

$$
\begin{aligned}
& \mathrm{CH}_{4}+\mathrm{SO}_{3} \underset{\substack{\mathrm{CH}_{3} \mathrm{SO}_{3} \mathrm{H} \\
75^{\circ} \mathrm{C}, 6 \mathrm{~h}}}{\stackrel{\text { Initiator }}{\longrightarrow}} \mathrm{CH}_{3} \mathrm{SO}_{3} \mathrm{H} \frac{\mathrm{SO}_{3}}{160^{\circ} \mathrm{C}, 10 \mathrm{~h}} \mathrm{CH}_{3} \mathrm{X} \underset{\mathrm{C}_{2} \mathrm{H}_{4} \mathrm{Cl}_{2}}{\longrightarrow} \mathrm{CH}_{3} \mathrm{OH} \\
& \mathrm{X}=\mathrm{OSO}_{3} \mathrm{H}, \mathrm{SO}_{3} \mathrm{CH}_{3}
\end{aligned}
$$

Scheme 1.3. A direct approach for partial oxidation of methane via a radical reaction using $\mathrm{SO}_{3}$ as the oxidant.

In the first step, a free-radical initiator (e.g., urea- $\mathrm{H}_{2} \mathrm{O}_{2}-\mathrm{RhCl}_{3}$ ) is used and methane is reacted with $\mathrm{SO}_{3}$ to form methanesulfonic acid in $7.2 \%$ yield based on methane. Methanol is produced from subsequent oxidation and hydrolysis in $13 \%$ yield based on methanesulfonic acid. For hydrocarbon transformations that proceed via radical-chain mechanism, the activation energy barrier is relatively low and radicals attack the $\mathrm{C}-\mathrm{H}$ bonds based on the bond strengths. Thereby, the reactivity of $\mathrm{C}-\mathrm{H}$ bonds decreases in the following orders: $3^{\circ}>2^{\circ}>1^{\circ}$. The fact that functionalized products usually possess weaker $\mathrm{C}-\mathrm{H}$ bonds than the alkane substrates gives rise to poor selectivity in such transformations. ${ }^{8}$ This inherent limitation makes selective conversion from methane to methanol in high yields challenging.

\subsubsection{Metal-mediated hydrocarbon functionalization}

Metal-mediated hydrocarbon transformations are very common in nature. For example, in biological systems, methane monooxygenase catalyzes the selective oxidation of methane to methanol by oxygen under ambient conditions. ${ }^{22}$ The $\mu$-oxo-bridged binuclear iron centers in methane monooxygenase are believed to be active sites. Metal-mediated hydrocarbon functionalization has been a research focus as well as an industrial interest 
for decades. This type of hydrocarbon transformation is usually promoted by metal oxides, inorganic salts, or transition metal complexes.

Hydrocarbon transformations promoted by solid metals or their oxides play a very important role in the chemical industry. The heterogeneous metal-containing catalysts are widely employed in oxidation, dehydrogenation, isomerization, oxidative coupling and other processes in which saturated and unsaturated hydrocarbons (e.g., long chain alkanes, olefins) are converted to useful commodities. ${ }^{5,23}$ Usually, such reactions occur at high temperature $\left(>200{ }^{\circ} \mathrm{C}\right.$ ) and generate multiple products in low yield and/or poor selectivity. ${ }^{4,24-26}$ Radicals are typically involved in the proposed mechanisms for heterogeneous metal-containing catalysts. At high temperature and pressure $\left(>500{ }^{\circ} \mathrm{C}, 10\right.$ bar), gas phase radical reactions are predominant and the catalysts have a minor contribution. $^{27,28}$ Lunsford and co-workers reported a series of metal oxide catalysts for oxidative coupling or partial oxidation of methane and the formation of hydroxyl or methyl radicals was observed upon abstraction of $\mathrm{H}$ atom from methane in these processes. ${ }^{29-31}$ Sen et al. reported the conversion of methane to methyl ester in $~ 2 \%$ yield at $85{ }^{\circ} \mathrm{C}$ catalyzed by a mixture of metallic $\mathrm{Pd}$ and $\mathrm{Cu}(\mathrm{II}) / \mathrm{CO} / \mathrm{O}_{2}$ in trifluoroacetic acid solution. ${ }^{4}$ It is very common that over-oxidation occurs in heterogeneously catalyzed reactions, yielding formaldehyde and $\mathrm{CO}_{2}$. Otsuka et al. investigated the reaction mechanism for the activation of methane and the formation of formaldehyde in the presence of $\mathrm{O}_{2}$ using $\mathrm{Fe}_{2}\left(\mathrm{MoO}_{4}\right)_{3}$ as the catalyst. ${ }^{32}$ It is found that methane is activated by the surface oxygen and the intermediates, adsorbed methyl or methoxide species, would be attacked by the activated surface oxygen, being oxidized to formaldehyde and $\mathrm{CO}_{2}$. 
They proposed that for selective synthesis of methanol, an active site that can provide a Brönsted acid and protect the intermediates from further oxidation by surface oxygen must be required. Although partial oxidation of longer chain alkanes with relatively high yields and good selectivity have been observed, extension of such processes to the partial oxidation of methane with high yield and good selectivity has not been successful. ${ }^{33-35}$

Attempts to control selectivity under mild conditions by the use of single-site heterogeneous catalysts have been reported. ${ }^{24,36}$ Neumann et al. developed a bipyrimidinylplatinum-poluoxometalate hybrid compound supported on silica, $\left[\mathrm{Pt}(\mathrm{Mebpym}) \mathrm{Cl}_{2}\right]\left[\mathrm{H}_{4} \mathrm{PV}^{2} \mathrm{MoO}_{40}\right] / \mathrm{SiO}_{2}$, which catalyzes the oxidation of methane in water under mild conditions $\left(50-60{ }^{\circ} \mathrm{C}, 1-2\right.$ bar $\left.\mathrm{O}_{2}\right) .{ }^{36}$ Despite the production of methanol, overoxidation and formation of other functionalized products (e.g., formaldehyde) still remain in this process. Recently, Hutchings et al. reported a iron- and copper-promoted zeolites (ZSM-5) that catalyze the direct conversion of methane to methanol in an aqueous medium by using $\mathrm{H}_{2} \mathrm{O}_{2}$ as the oxidant. ${ }^{37}$ The selectivity to methanol reached 93\% with more than 35 turnovers. Because it is normally difficult to elucidate the nature and mechanism of heterogeneous catalysis, the development of well-tuned catalysts for desired reactivity and selectivity is challenging.

Given the limitations of radical processes and heterogeneous catalysts for hydrocarbon functionalization, transition metal complexes as homogeneous catalysts provide a promising option for such transformations because the mechanisms can often be thoroughly elucidated and the structures can be systematically tuned. As mentioned above, methane monooxygenase in biological systems catalyzes the selective oxidation of 
methane to methanol. As early as late $19^{\text {th }}$ century, chemists reported examples of transition metal systems for hydrocarbon conversion. ${ }^{38-40}$ For example, the Fenton reagent, which consists of $\mathrm{Fe}^{2+} / \mathrm{H}_{2} \mathrm{O}_{2}$ and promotes hydroxylation of alkanes, was developed in the 1890 s. ${ }^{39,40}$ In early studies, metal cations with high oxidation state were generally used as oxidants. For example, Shilov and co-workers employed a Pt(II)/Pt(IV) system in aqueous solution that can convert methane to methanol as well as methyl chloride (Details of the Shilov systems will be given in section 1.1 .5$).{ }^{41}$ By using a Pd(II) salt as the catalyst, Sen et al. successfully converted methane to methyl trifluoroacetate in trifluoroacetic acid solution in $\sim 1 \%$ yield at $90{ }^{\circ} \mathrm{C}$ (eq. 1). ${ }^{42}$ Herrmann et al. has reported that the selective conversion of methane into methyl trifluoroacetate can also be achieved by using $\mathrm{Pd}(\mathrm{II})$ complexes with $\mathrm{N}$-heterocyclic carbene (NHC) ligands in carboxylic acids. (eq. 2). ${ }^{43}$

$$
\begin{aligned}
& \mathrm{CH}_{4}+\mathrm{Pd}\left(\mathrm{O}_{2} \mathrm{CR}\right)_{2} \underset{90^{\circ} \mathrm{C}}{\stackrel{\mathrm{CF}_{3} \mathrm{COOH}}{\longrightarrow}} \mathrm{CF}_{3} \mathrm{COOCH}_{3}+\mathrm{Pd}(0)+\mathrm{RCOOH} \\
& \text { }
\end{aligned}
$$

Periana et al. reported that methane could be converted into methyl bisulfate by $\mathrm{Hg}$ (II) in concentrated sulfuric acid (eq. 3). ${ }^{44}$ Sulfuric acid acts as an oxidant in this process. The selectivity to methyl bisulfate was up to $85 \%$ at methane conversion of $50 \%\left(180{ }^{\circ} \mathrm{C}\right.$, 34.5 bar of methane). After the discovery of the $\mathrm{Hg}$ (II) catalyst, Periana and co-workers reported a bipyrimidyl $\mathrm{Pt}(\mathrm{II})$ complex that catalyzes the selective conversion of methane 
into methyl bisulfate in oleum with a selectivity of $81 \%$ and methane conversion of $90 \%$ (eq. 4$){ }^{45}$ Sulfur in the +6 oxidation state $\left(\mathrm{H}_{2} \mathrm{SO}_{4}\right.$ or $\left.\mathrm{SO}_{3}\right)$ serves as the oxidant in this reaction. The rate constant for further oxidation of methyl bisulfate was 100 times slower than that of oxidation of methane. The high selectivity for methyl bisulfate was explained by the lower reactivity of the product as compared with methane. Similar reactions catalyzed by a homogeneous, cationic gold system have also been reported by Periana and co-workers. ${ }^{46}$

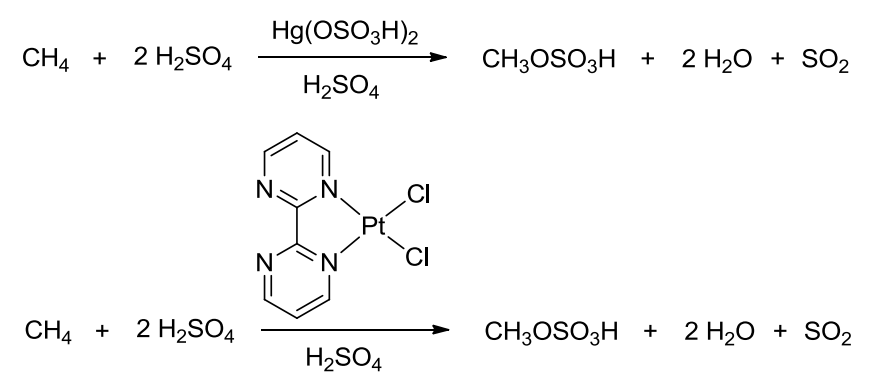

In addition to the selective conversion of methane to methanol, the direct oxidative carbonylation of methane catalyzed by homogeneous transition metal systems has been reported. Nishiguchi et al. developed a $\mathrm{Pd}$ - and $\mathrm{Cu}$-catalyzed system that can convert methane and $\mathrm{CO}$ to acetic acid in the presence of $\mathrm{K}_{2} \mathrm{~S}_{2} \mathrm{O}_{8}$ and trifluoroacetic acid. ${ }^{47}$ Fujiwara et al. found that the same carbonylation reaction can also be catalyzed by $\mathrm{CaCl}_{2}{ }^{48}$ Lin and Sen reported the carbonylation of methane to acetic acid with $\mathrm{CO}$ and $\mathrm{O}_{2}$ in aqueous solution in the presence of $\mathrm{RhCl}_{3}$ (eq. 5). ${ }^{17,49}$ The carbonylation reaction was remarkably enhanced by $\mathrm{Pd} / \mathrm{C}$ or iodide ion. By addition of iodide ion, $\left[\mathrm{Rh}(\mathrm{CO}) \mathrm{I}_{2}\right]^{-}$ was formed, which is the starting complex in the catalytic cycle of the Monsanto process for the carbonylation of methanol to acetic acid. ${ }^{50}$ However, acetic acid was not formed if 
methane was replaced with methanol in Sen's system, indicating that methanol is not an intermediate.

$$
\mathrm{CH}_{4}+\mathrm{CO}+\mathrm{O}_{2} \frac{\mathrm{RhCl}_{3}}{\mathrm{KI}, \mathrm{H}_{2} \mathrm{O}, 100^{\circ} \mathrm{C}} \mathrm{CH}_{3} \mathrm{COOH}
$$

Although the term $\mathrm{C}-\mathrm{H}$ activation is commonly used in describing the partial oxidation process of hydrocarbons, it must be noted that not all $\mathrm{C}-\mathrm{H}$ bond cleavage reactions initiated by transition metal complexes should be called $\mathrm{C}-\mathrm{H}$ activation reactions. Generally, the term of $\mathrm{C}-\mathrm{H}$ activation refers to the direct interaction between $\mathrm{C}-\mathrm{H}$ bonds and a transition metal center, which precedes $\mathrm{C}-\mathrm{H}$ bond cleavage. For metals with d-electrons, metal- $\mathrm{CH}$ bonding is generally considered to have a $\sigma$-bonding and $\pi$ bonding component. The $\sigma$-bonding involves donation of electrons in the $\mathrm{C}-\mathrm{H} \sigma$-bond into an empty metal orbital, which decreases $\mathrm{C}-\mathrm{H}$ electron density. The $\pi$-bonding involves back-donation of electrons in a $d \pi$ orbital into the $\mathrm{C}-\mathrm{H} \sigma^{*}$ orbital (Scheme 1.4). Both interactions, which are synergistic, serve to weaken and activate the $\mathrm{C}-\mathrm{H}$ bond toward cleavage.

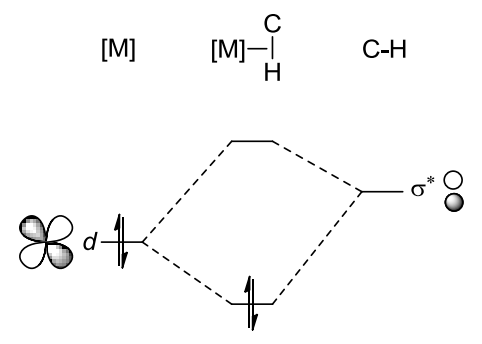

Scheme 1.4. Transition-metal-mediated $\mathrm{C}-\mathrm{H}$ activation.

$\mathrm{C}-\mathrm{H}$ bond cleavage mechanisms by metal complexes containing nondative heteroatomic ligands ( $\mathrm{M}-\mathrm{X}$, where $\mathrm{X}=\mathrm{O}, \mathrm{OR}, \mathrm{OH}, \mathrm{NHR}, \mathrm{NR}$, etc.) include: 1) 
heterolytic $\mathrm{C}-\mathrm{H}$ bond cleavage, ${ }^{51-58}$ 2) homolytic $\mathrm{C}-\mathrm{H}$ bond cleavage, ${ }^{59-66}$ and 3) net 1,2addition across $\mathrm{M}-\mathrm{X}$ bonds ${ }^{67-72}$ (Scheme 1.5).

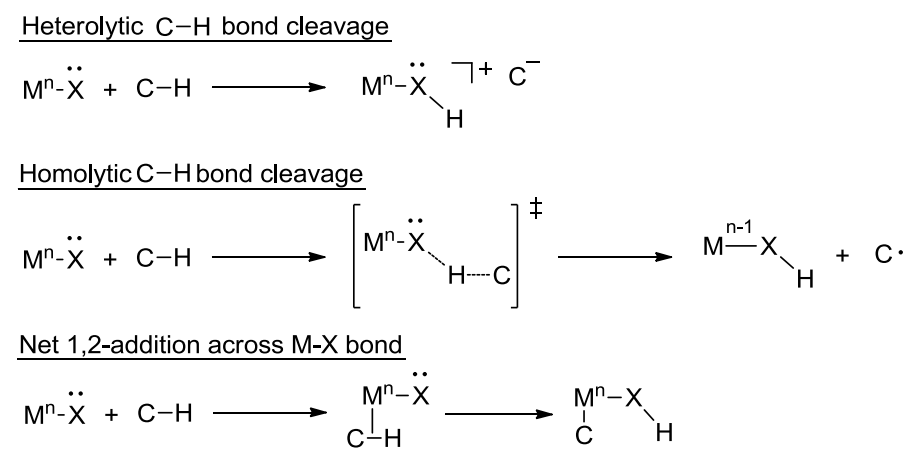

Scheme 1.5. Different pathways of $\mathrm{C}-\mathrm{H}$ bond cleavage by transition metal complexes containing nondative heteroatomic ligands $(\mathrm{X})$.

The first two types of $\mathrm{C}-\mathrm{H}$ bond cleavage typically proceed via a ligand-centered pathway without direct contact of the $\mathrm{C}-\mathrm{H}$ bond with the metal center and are only observed for acidic or relatively weak $\mathrm{C}-\mathrm{H}$ bonds. For example, for complexes with unfavorable $n-1$ oxidation states and unavailable coordination sites, the basicity of $\mathrm{X}$ ligands typically allows the observation of intermolecular heterolytic even-electron cleavage of relatively acidic $\mathrm{C}-\mathrm{H}$ bonds such as phenylacetylene, malononitrile, 1,4cyclohexadiene and fluorene. Complexes with favorable $n-1$ oxidation states and unavailable coordination sites usually undergo intermolecular homolytic odd-electron cleavage of relatively weak $\mathrm{C}-\mathrm{H}$ bonds (i.e., hydrogen atom abstraction). Examples of the homolytic type of mechanism usually involve metal centers in high oxidation states. It must be noted that the metal center is reduced in the process of homolytic $\mathrm{C}-\mathrm{H}$ bond cleavage, which is generally considered to be the driving force for this type of reaction. ${ }^{60}$ In contrast, the third type of $\mathrm{C}-\mathrm{H}$ bond cleavage is typically thought to involve a direct interaction between the metal and the substrate. Because the net 1,2-addition pathway is a 
metal-mediated process, its reactivity is rooted in the energetics and symmetries of molecular orbitals. As a result, the net 1,2-addition pathway exhibits different selectivity from the heterolytic or homolytic $\mathrm{C}-\mathrm{H}$ bond cleavage, in which the acidity or the strength of $\mathrm{C}-\mathrm{H}$ bonds dominates the reaction selectivity, respectively. Given that the net 1,2addition is a metal-mediated process, it might be feasible to selectively activate stronger and/or less acidic $\mathrm{C}-\mathrm{H}$ bonds in the presence of weaker and/or more acidic $\mathrm{C}-\mathrm{H}$ bonds.

Among the $\mathrm{C}-\mathrm{H}$ bond activation reactions that occur via a net 1,2-addition pathway, possible mechanisms include $\sigma$-bond metathesis, oxidative addition and electrophilic substitution (Scheme 1.6). However, clear distinction between these mechanisms/processes is often difficult. It can be observed that a feature of $\mathrm{C}-\mathrm{H}$ bond activation by $\mathrm{M}-\mathrm{X}$ is the existence of a lone pair on $\mathrm{X}$ ligands; however, questions still remain regarding the importance of the lone pair for the 1,2-addition pathway. ${ }^{73,74}$ Only a few examples of $\mathrm{C}-\mathrm{H}$ bond activation via 1,2-addition to $\mathrm{M}-\mathrm{X}$ bonds have been published and their mechanisms are not well understood (For details, see section 1.1.6).

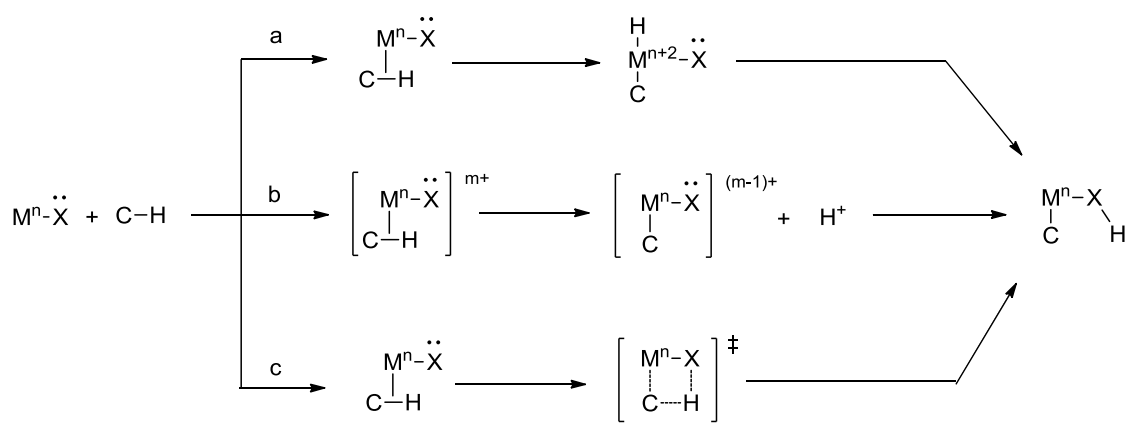

Scheme 1.6. Three predominant mechanisms of $\mathrm{C}-\mathrm{H}$ bond activation via the 1,2addition pathway: (a) oxidative addition; (b) electrophilic substitution; (c) $\sigma$-bond metathesis. 


\subsubsection{Shilov system for hydrocarbon functionalization}

Among the reported examples of successful oxy-functionalization of hydrocarbons, the Shilov system, developed in the 1970s, is a milestone in the development of a catalytic process for conversion of alkanes to alcohols or other functionalized molecules. $^{41}$ It utilizes Pt(II) as catalyst in aqueous solution (Scheme 1.7). The initial C$\mathrm{H}$ activation produces a $\mathrm{Pt}(\mathrm{II})$-alkyl intermediate, which is oxidized by $\left[\mathrm{PtCl}_{6}\right]^{2-}$ to yield a Pt(IV)-alkyl intermediate. Nucleophilic attack by water or chloride on the Pt(IV)-alkyl intermediate followed by reductive elimination releases alcohol or alkyl chloride and reforms the $\mathrm{Pt}(\mathrm{II})$ starting material. In this process, $\mathrm{C}-\mathrm{H}$ bond activation occurs at $\mathrm{Pt}(\mathrm{II})$ while the subsequent nucleophilic attack and $\mathrm{C}-\mathrm{X}$ bond formation require $\mathrm{Pt}(\mathrm{IV})$ because electrophilic alkyl ligands are provided upon the oxidation of metal center. The oxidants in this process are typically $\mathrm{Pt}(\mathrm{IV})$ salts, such as $\mathrm{Na}_{2} \mathrm{PtCl}_{6}$ and $\left(\mathrm{NH}_{4}\right)_{2} \mathrm{PtCl}_{6}$. The stoichiometric use of expensive Pt(IV) salts inhibits the use of this system on a large scale, and the development of processes with other oxidants has been challenging. ${ }^{75-77}$

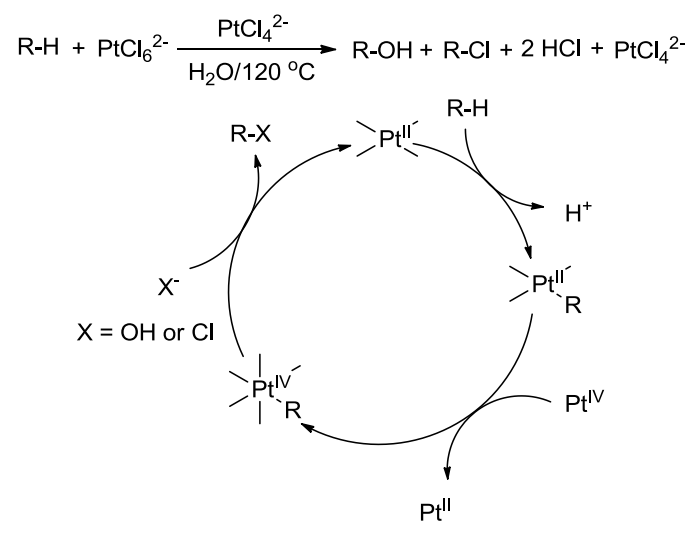

Scheme 1.7. Shilov system: stoichiometric use of $\mathrm{Pt}(\mathrm{IV})$ salts as oxidant for producing nucleophilic alkyl ligands. 


\subsubsection{Non-Shilov system for hydrocarbon functionalization}

Catalysts that operate through pathways that are different than Shilov-type systems might provide alternatives to avoid the use of expensive oxidants. As mentioned above, a catalytic cycle for the partial oxidation of hydrocarbons consists of two key steps, $\mathrm{C}-\mathrm{H}$ activation and oxy-functionalization. Potential alternatives to the Shilov system are shown in Scheme 1.8.
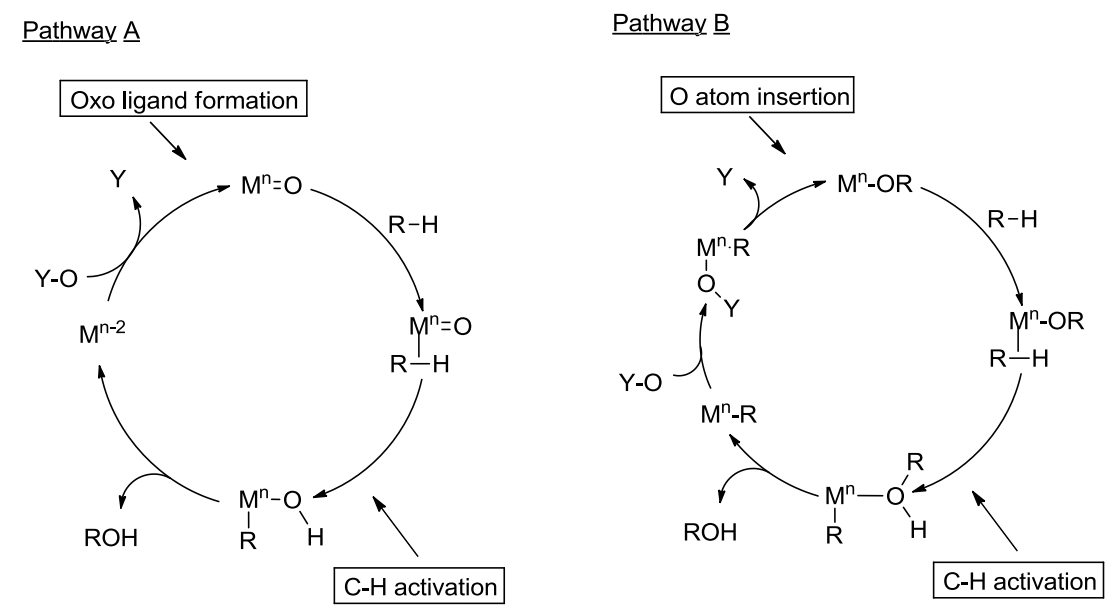

Scheme 1.8. Catalytic cycle for hydrocarbon functionalization via 1,2-addition pathways.

Pathway A involves metal-oxo complexes $(\mathrm{M}=\mathrm{O})$ and Pathway B involves metalalkoxide complexes (M-OR). A notable difference between Pathway A and B is the $\mathrm{C}-\mathrm{O}$ reductive elimination step in Pathway $\mathrm{A}$. In contrast, the $\mathrm{C}-\mathrm{O}$ bond forming step in Pathway $\mathrm{B}$ involves $\mathrm{O}$ atom insertion into a $\mathrm{M}-\mathrm{R}$ bond. The $\mathrm{C}-\mathrm{H}$ activation step in both Pathway A and B is an even-electron process and does not change the formal oxidation state of metal center, which makes it distinct from the homolytic $\mathrm{C}-\mathrm{H}$ bond cleavage (see above). 
$\mathrm{C}-\mathrm{H}$ activation similar to that shown in Pathway A has been demonstrated with early transition metal imido complexes. ${ }^{78-81}$ These systems undergo $\mathrm{C}-\mathrm{H}$ addition across $\mathrm{M}=\mathrm{NR}$ bonds to yield amido complexes (M-NHR) (Scheme 1.9).

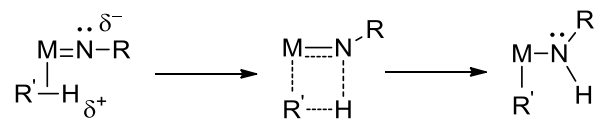

Scheme 1.9. C-H activation using early transition metal-imido complexes.

In 1988, Wolczanski et al. reported an early transition metal system, via transient ( $t$ $\left.\mathrm{Bu}_{3} \mathrm{SiNH}\right)_{2} \mathrm{Zr}=\mathrm{NSi}-t-\mathrm{Bu}_{3}$, that is capable of $\mathrm{C}-\mathrm{H}$ bond activation of benzene and methane as well as the activation of dihydrogen (Scheme 1.10). ${ }^{78}$ In the presence of methane and cyclohexane, the transient $\mathrm{Zr}$ complex exclusively activates the $\mathrm{C}-\mathrm{H}$ bond of methane. Such selective activation also occurs when both dihydrogen and cyclohexane are available, yielding only the dihydrogen activation product.

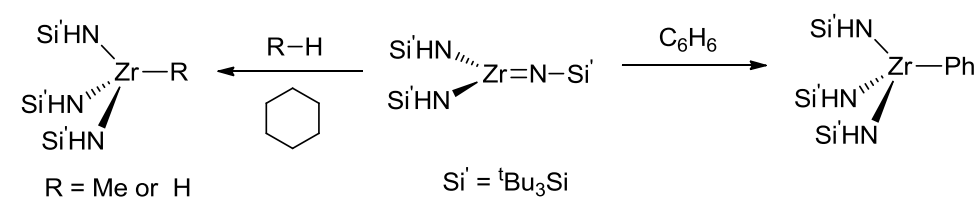

Scheme 1.10. $\mathrm{C}-\mathrm{H} / \mathrm{H}-\mathrm{H}$ activation via transient $\left(t-\mathrm{Bu}_{3} \mathrm{SiNH}\right)_{2} \mathrm{Zr}=\mathrm{NSi} t-\mathrm{Bu}_{3}$.

Typically, an imido ligand in early metal systems forms a stable triple bond with the metal center. $^{82}$ In the intermediate of Wolczanski's system, $d \pi-p \pi$ interactions are available perpendicular to and in the pseudo-trigonal plane, but the interaction in the pseudo-trigonal plane is weaker because of the energy mismatch of the $\mathrm{N} 2 p$ orbital and $\mathrm{Zr} d \sigma^{*}$ orbital and symmetry constraints, resulting in a decrease in the metal-imido bond order. $^{78}$ This increases the electron density at the imido $\mathrm{N}$ atom and enhances the 
electrophilicity of metal center, enabling the polarization of a $\mathrm{C}-\mathrm{H}$ bond and rendering it susceptible to activation. Computational studies by Wolczanski and Cundari et al. have revealed the feasibility of $\mathrm{C}-\mathrm{H}$ activation via 1,2 -addition across a $\mathrm{M}-\mathrm{X}$ bond and the importance of $\mathrm{C}-\mathrm{H}$ coordination to the metal center as well as the polarity of the metalimido bond in the activation reaction. ${ }^{83-85}$ Although these systems are capable of $\mathrm{C}-\mathrm{H}$ activation, subsequent $\mathrm{C}-\mathrm{N}$ reductive elimination to release free amine is highly unfavorable and has not been observed, likely because reductive elimination from electropositive early transition metals is highly unfavorable. As a result, the incorporation of early transition metal complexes into a catalytic cycle is a substantial challenge. In contrast, examples of late(r) transition metal complexes that can undergo $\mathrm{C}-\mathrm{N}$ or $\mathrm{C}-\mathrm{O}$ reductive elimination and release functionalized products have been demonstrated. ${ }^{86-88}$

Ligand-to-metal $\pi$-donation is disrupted in high $d$-count late(r) transition metal complexes due to the filled $d \pi$ orbitals of metal center (Scheme 1.11$).{ }^{58,89,90}$ Such $\pi$ conflict will likely enhance the basicity/nucleophilicity of the heteroatomic ligands because the lone pair is no longer delocalized along the $\mathrm{M}-\mathrm{X}$ bond. The basic and nucleophilic characteristics of $\mathrm{X}$ ligands should enhance $\mathrm{C}-\mathrm{H}$ bond activation (see above), and these characteristics have been demonstrated by late transition metalamido/alkoxide/hydroxide complexes. ${ }^{58,91}$ For example, our group reported the acid/base reaction of $\mathrm{Ru}(\mathrm{II})$-amido complexes with malononitrile, 1,4-cyclohexadiene, and phenylacetylene. ${ }^{55-57}$ 


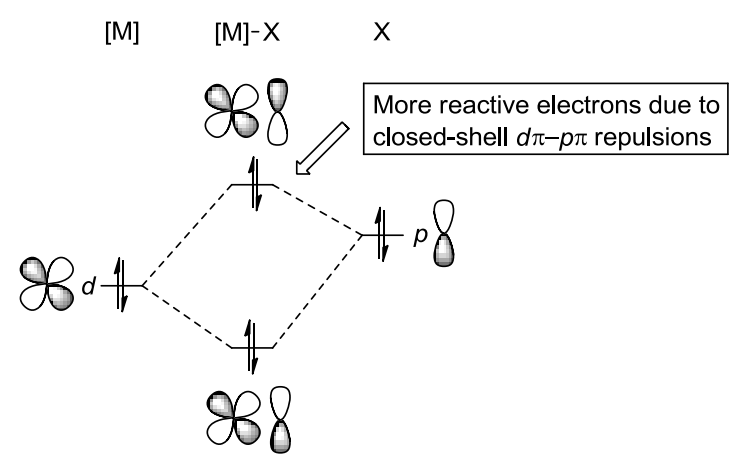

Scheme 1.11. $\pi$-Conflict in high $d$-electron count late(r) transition metal complexes.

The combination of $\operatorname{TpRu}(\mathrm{L})\left(\mathrm{L}^{\prime}\right)(\mathrm{NHPh})\left(\mathrm{Tp}=\right.$ hydridotris(pyrazolyl)borate; $\mathrm{L}=\mathrm{L}^{\prime}=$ $\mathrm{PMe}_{3}$ or $\mathrm{P}(\mathrm{OMe})_{3}$ or $\mathrm{L}=\mathrm{CO}$ and $\left.\mathrm{L}^{\prime}=\mathrm{PPh}_{3}\right)$ with malononitrile $\left(\mathrm{p} K_{\mathrm{a}}=11\right.$ in DMSO $)$ in methylene chloride results in an immediate acid/base reaction at room temperature (eq. 6). Similar reactivity was observed for the mixture of $\mathrm{TpRu}(\mathrm{L})\left(\mathrm{L}^{\prime}\right)\left(\mathrm{NH}_{2}\right)$ and phenylacetylene ( $K_{\mathrm{a}}=23$ in DMSO) in THF at room temperature, which forms a $\mathrm{Ru}-$ amine/acetylide ion pair (eq. 7). The reaction of $\mathrm{TpRu}(\mathrm{PMe} 3)(\mathrm{NHR})\left(\mathrm{R}=\mathrm{H}\right.$ or $\left.{ }^{t} \mathrm{Bu}\right)$ and 1,4-cyclohexadiene at $80{ }^{\circ} \mathrm{C}$ results in the formation of a $\mathrm{Ru}$-hydride complex and benzene (eq. 8). Other examples of highly basic Ru(II) amido moiety include Bergman's et al. $\mathrm{Ru}$-amido complex, trans-(DMPE) ${ }_{2} \mathrm{Ru}\left(\mathrm{NH}_{2}\right)(\mathrm{H}) \quad[\mathrm{DMPE}=1$,2-bis-(dimethylphosphinoethane)] that is able to deprotonate triphenylmethane $\left(\mathrm{p} K_{\mathrm{a}}=30.6\right.$ in DMSO)..$^{52,92}$

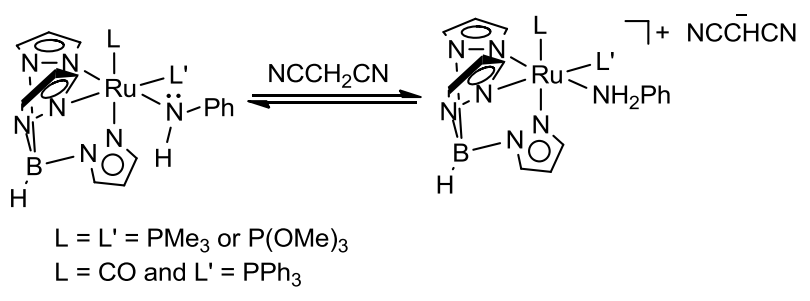




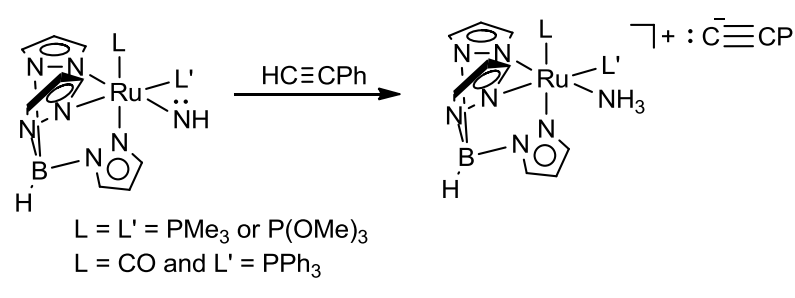

Highly basic/nucleophilic metal amido moieties provide an opportunity to extend 1,2$\mathrm{CH}$-addition to late(r) transition metal complexes. Given that the production of amines or alcohols after hydrocarbon $\mathrm{C}-\mathrm{H}$ activation across $\mathrm{M}-\mathrm{X}$ bonds $(\mathrm{X}=$ amido or alkoxide $)$ does not require a reductive elimination, it is possible and advantageous to incorporate late transition metal amido/alkoxide complexes into Pathway B (see Scheme 1.8). As a result, recent major efforts have been focused on developing late transition metal systems with heteroatom bonds for $\mathrm{C}-\mathrm{H}$ bond activation. ${ }^{67-73,93-95}$

In 2004, our group reported dihydrogen activation and intramolecular $\mathrm{C}-\mathrm{H}$ activation by the coordinatively unsaturated $\mathrm{d}^{6}$ comples, $(\mathrm{PCP}) \mathrm{Ru}(\mathrm{CO})\left(\mathrm{NH}_{2}\right)\left[\mathrm{PCP}=2,6-\left(\mathrm{CH}_{2} \mathrm{P}-t-\right.\right.$ $\left.\mathrm{Bu}_{2}\right)_{2} \mathrm{C}_{6} \mathrm{H}_{3}$ ] (Scheme 1.12). ${ }^{73}$ The production of free ammonia and the formation of a $\mathrm{Ru}-$ hydride bond after dihydrogen activation indicates a net 1,2-addition of $\mathrm{H}-\mathrm{H}$ bond across the $\mathrm{Ru}$-amido bond. In the presence of hydrocarbons, only intramolecular $\mathrm{C}-\mathrm{H}$ activation of a $t$-Bu moiety is observed, yielding a cyclometalated complex and free ammonia. The intramolecular $\mathrm{C}-\mathrm{H}$ activation of a ${ }^{t} \mathrm{Bu}$ moiety is also observed for the analogous $\mathrm{Ru}-$ methyl complex $(\mathrm{PCP}) \mathrm{Ru}(\mathrm{CO})\left(\mathrm{CH}_{3}\right)$ (Scheme 1.12), whose rate of conversion is five times faster than that of the analogous $\mathrm{Ru}$-amido complex at $50{ }^{\circ} \mathrm{C}$ in benzene. 


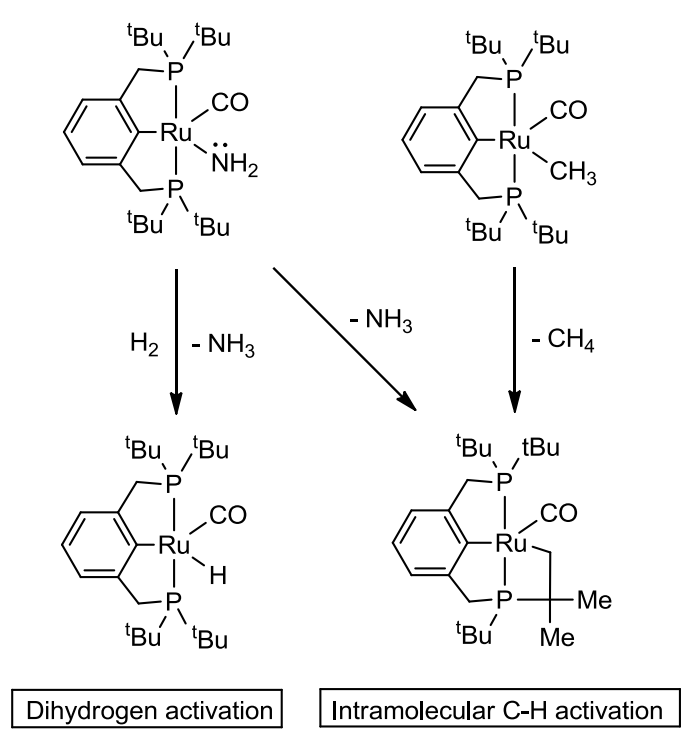

Scheme 1.12. Dihydrogen activation and intramolecular $\mathrm{C}-\mathrm{H}$ activation by coordinatively unsaturated $(\mathrm{PCP}) \mathrm{Ru}(\mathrm{CO})(\mathrm{X})\left(\mathrm{X}=\mathrm{NH}_{2}\right.$ or $\left.\mathrm{CH}_{3}\right)$.

Determination of activation parameters reveals identical $\Delta H^{\ddagger}=18(1) \mathrm{kcal} / \mathrm{mol}$ for the intramolecular $\mathrm{C}-\mathrm{H}$ activation by both $\mathrm{Ru}$-amido and -methyl complexes. However, the $\Delta S^{\ddagger}$ for the activation by $\mathrm{Ru}$-amido complex is $-23(4)$ eu while the $\Delta S^{\ddagger}$ for the activation by $\mathrm{Ru}-$ methyl complex is $-18(4)$ eu. The different reaction rates of intramolecular $\mathrm{C}-\mathrm{H}$ activation by these two complexes are possibly due to the difference in $\Delta S^{\ddagger}$ for the two transformations.

DFT (B3LYP/SBK(d)) calculations were performed to compare the energetics of $\mathrm{R}-\mathrm{H}$ activation $\left(\mathrm{R}=\mathrm{H}\right.$ or $\left.\mathrm{CH}_{3}\right)$ by $\left(\mathrm{PCP}^{\prime}\right) \mathrm{Ru}(\mathrm{CO})\left(\mathrm{NH}_{2}\right)$. $\mathrm{PCP}^{\prime}$ is a model of the full $\mathrm{PCP}$ ligand that is generated by the replacement of the $t$-Bu groups with hydrogen. The results are shown in Scheme 1.13. The calculations are in agreement with experimental observations. Dihydrogen activation is exothermic by $17 \mathrm{kcal} / \mathrm{mol}$ and exergonic by 9 $\mathrm{kcal} / \mathrm{mol}$. The corresponding methane activation is endothermic by $4 \mathrm{kcal} / \mathrm{mol}$ and endergonic by $14 \mathrm{kcal} / \mathrm{mol}$. The calculated BDE change for the conversion of a nondative 
$\mathrm{Ru}-$ amido bond to a $\mathrm{Ru}-\mathrm{ammonia}$ bond upon methane activation is substantial $(\triangle \mathrm{BDE}=$ $40 \mathrm{kcal} / \mathrm{mol})$. Due to breaking the methane $\mathrm{C}-\mathrm{H}$ bond and forming the $\mathrm{Ru}-\mathrm{CH}_{3}$ and $\mathrm{N}-\mathrm{H}$ bonds, the change in $\mathrm{BDE}$ is more than the $32 \mathrm{kcal} / \mathrm{mol}$ (less than $40 \mathrm{kcal} / \mathrm{mol}$ ), explaining the calculated endothermic nature of methane activation. Similarly, the calculation for dihydrogen activation also indicates a significant loss in enthalpy due to the conversion of a $\mathrm{Ru}-$ amido bond to a $\mathrm{Ru}-\mathrm{ammonia}$ bond. However, the $\mathrm{Ru}-\mathrm{H}$ bond enthalpy is $24.1 \mathrm{kcal} / \mathrm{mol}$ stronger than the $\mathrm{Ru}-\mathrm{CH}_{3}$ bond enthalpy, which provides an explanation for the calculated exothermic nature of dihydrogen activation. This enthalpy difference between $\mathrm{Ru}-\mathrm{H}$ and $\mathrm{Ru}-\mathrm{CH}_{3}$ bonds is consistent with experimental observations that $(\mathrm{PCP}) \mathrm{Ru}(\mathrm{CO})\left(\mathrm{NH}_{2}\right)$ can undergo dihydrogen activation but intermolecular $\mathrm{C}-\mathrm{H}$ activation of methane was not observed.

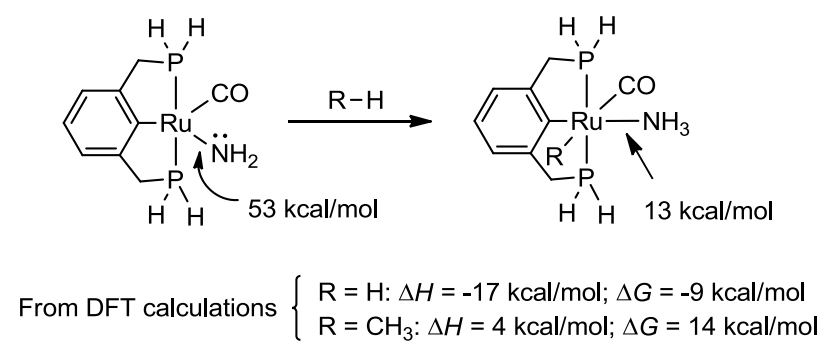

Scheme 1.13. DFT calculations (B3LYP/SBK(d)) for the activation of dihydrogen and methane by $\left(\mathrm{PCP}^{\prime}\right) \mathrm{Ru}(\mathrm{CO})\left(\mathrm{NH}_{2}\right)$.

Other examples of dihydrogen activation by late transition metal-heteroatom complexes include Gunnoe's ('bpy)Pt(Me)(NHPh) ('bpy = 4,4'-ditert-butyl-2,2'-dipyridyl) and Goldberg's (PCP)Pd(OR) [PCP = 2,6- $\left(\mathrm{CH}_{2} \mathrm{P}-t-\mathrm{Bu}_{2}\right)_{2} \mathrm{C}_{6} \mathrm{H}_{3} ; \mathrm{R}=\mathrm{H}$ or $\left.\mathrm{CH}_{3}\right]$ (Scheme 1.14). ${ }^{96,97}$ Dihydrogen activation by ('bpy) $\mathrm{Pt}(\mathrm{Me})(\mathrm{NHPh})$ produces aniline and 
$\left({ }^{t}\right.$ bpy $) \operatorname{Pt}(\mathrm{Me})(\mathrm{H})$. The latter complex ultimately decomposes to free tbpy ligand, methane and elemental Pt.

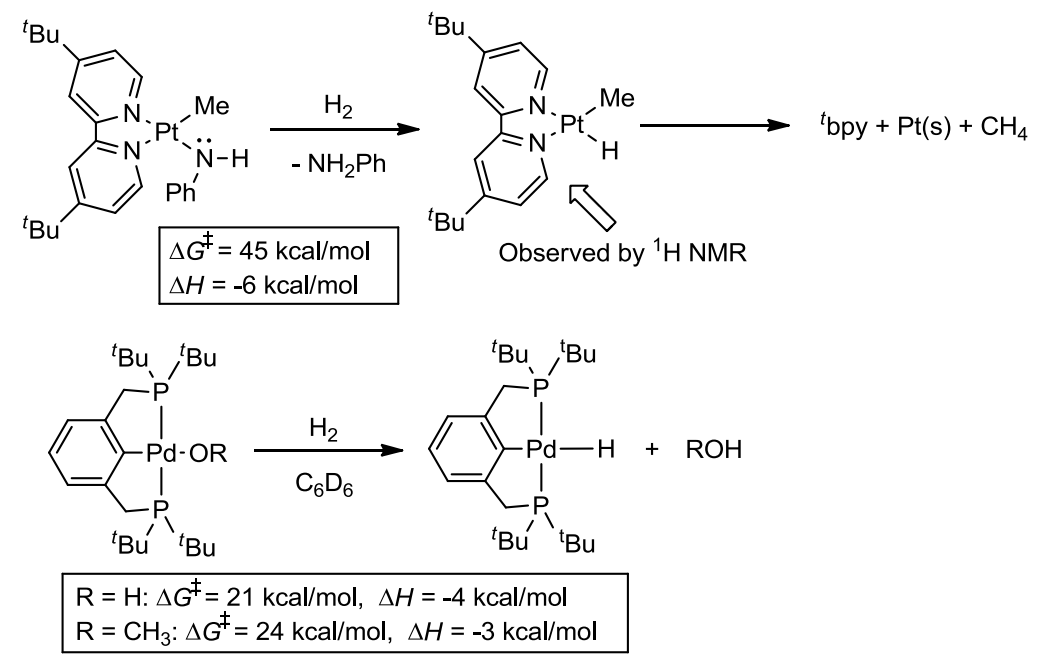

Scheme 1.14. Dihydrogen activation by ( ${ }^{t}$ bpy $) \mathrm{Pt}(\mathrm{Me})(\mathrm{NHPh})$ and $(\mathrm{PCP}) \mathrm{Pd}(\mathrm{OR})(\mathrm{R}=\mathrm{H}$ or $\mathrm{CH}_{3}$ ).

The dihydrogen activation reaction of ('bpy) $\mathrm{Pt}(\mathrm{Me})(\mathrm{NHPh})$ is calculated to be exothermic by $6 \mathrm{kcal} / \mathrm{mol}$ with a barrier of $45 \mathrm{kcal} / \mathrm{mol}$. Kinetic studies suggest that, rather than direct activation of dihydrogen across the $\mathrm{Pt}$-anilido bond, this activation process is catalyzed by elemental Pt. A standard $\mathrm{Hg}$ test showed the complete suppression of reactivity. An induction period was observed until visible formation of $\mathrm{Pt}(\mathrm{s})$. The removal of $\mathrm{Pt}(\mathrm{s})$ introduced a second induction period. If $10 \mathrm{wt} \%$ of $\mathrm{Pt}$ was added before pressurization with $\mathrm{H}_{2}$, the reaction rate was remarkably enhanced (50\% of Pt complexes converted after 5 min, reaction completed in $<1 \mathrm{~h}$ ). Without $\mathrm{H}_{2}$, no reaction was observed in the presence of Pt(s). Calculations suggest that the substantial difference in activation barrier between ('bpy) $\mathrm{Pt}(\mathrm{Me})(\mathrm{NHPh})$ and $(\mathrm{PCP}) \mathrm{Pd}(\mathrm{OMe})$ is due in equal parts to replacement of the metal, activating ligand and supporting ligand. ${ }^{96}$ The increase 
in electrophilicity of metal center upon substituting Pd for Pt would likely facilitate $\mathrm{H}_{2}$ activation. For ( $\left.{ }^{t} \mathrm{bpy}\right) \mathrm{Pt}(\mathrm{Me})(\mathrm{NHPh})$, the amido lone pair must be aligned perpendicular to the Pt square plane to accept a $\mathrm{H}$ atom, which would place the phenyl ring in close proximity to the methyl or ${ }^{t}$ bpy ligand and result in a steric inhibition.

After observation of dihydrogen and intramolecular $\mathrm{C}-\mathrm{H}$ activation by late(r) transition metal-heteroatom moieties, efforts have been focused on developing late transition metal systems capable of intermolecular hydrocarbon $\mathrm{C}-\mathrm{H}$ activation across the $\mathrm{M}-\mathrm{X}$ bonds. The first examples of late transition metal complexes that undergo intermolecular $\mathrm{C}-\mathrm{H}$ activation across $\mathrm{M}-\mathrm{X}$ bonds to form new $\mathrm{M}-\mathrm{C}$ bonds were reported by Gunnoe and Periana in 2005, utilizing $\mathrm{Ru}(\mathrm{II})$-hydroxide and $\operatorname{Ir}(\mathrm{III})$-methoxide complexes, respectively. ${ }^{67,69}$ In 2007, Goldberg reported that $\mathrm{Rh}(\mathrm{I})$ hydroxide and phenoxide complexes possess similar reactivity. ${ }^{72}$

The $\mathrm{Ru}(\mathrm{II})$ complexes developed by our group have the general formula of $\mathrm{TpRu}\left(\mathrm{PMe}_{3}\right)_{2}(\mathrm{XH})(\mathrm{X}=\mathrm{NPh}$ or $\mathrm{O})$. In deuterated benzene, H/D exchange is observed between the heteroatomic ligand and the solvent at elevated temperatures $\left(80-130{ }^{\circ} \mathrm{C}\right)$ (Scheme 1.15). Kinetic and computational studies reveal that the H/D exchange process is likely initiated by $\mathrm{PMe}_{3}$ dissociation, $\mathrm{C}-\mathrm{D}$ coordination and net $\mathrm{D}^{+}$transfer to the heteroatom (Scheme 1.16).

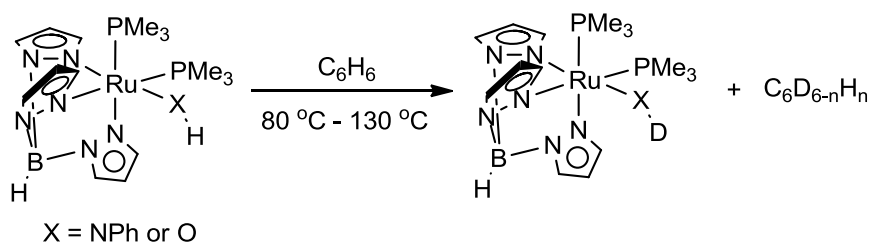

Scheme 1.15. $\mathrm{H} / \mathrm{D}$ exchange between $\mathrm{TpRu}\left(\mathrm{PMe}_{3}\right)_{2}(\mathrm{XH})$ and $\mathrm{C}_{6} \mathrm{D}_{6}$. 


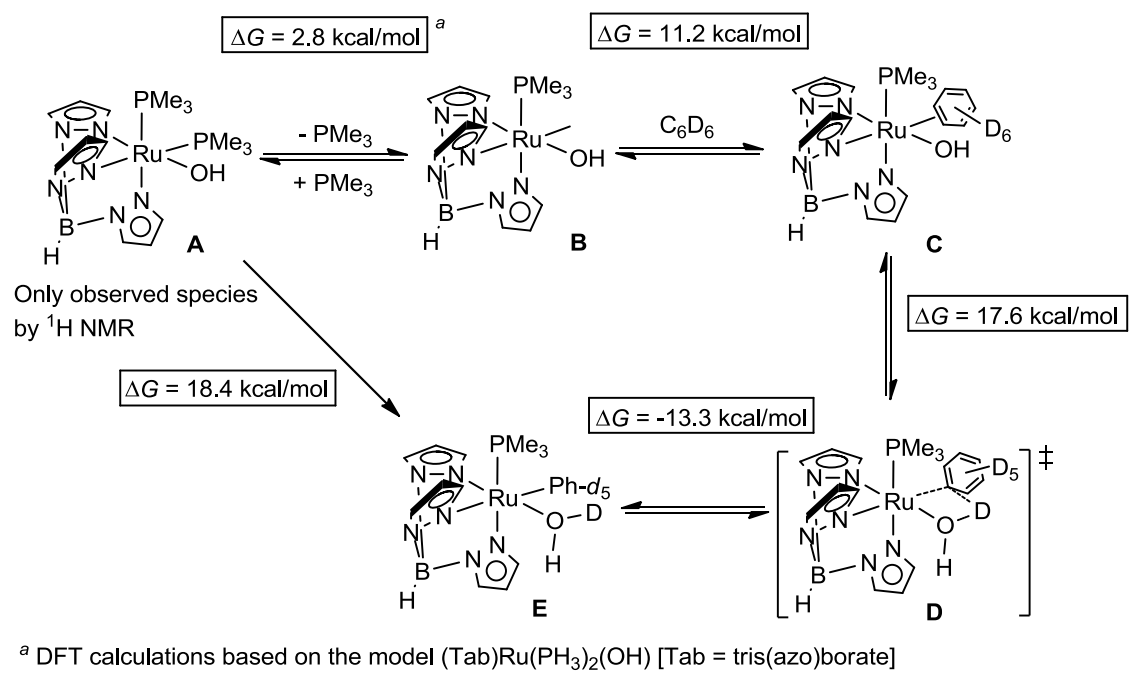

Scheme 1.16. Proposed catalytic pathway for $\mathrm{H} / \mathrm{D}$ exchange between $\mathrm{TpRu}\left(\mathrm{PMe}_{3}\right)_{2}(\mathrm{OH})$ and benzene- $d_{6}$.

Kinetic studies reveal that H/D exchange at the hydroxide ligand in benzene- $d_{6}$ is first order with $k_{\mathrm{obs}}=8.0(2) \times 10^{-5} \mathrm{~s}^{-1}\left(80{ }^{\circ} \mathrm{C}, t_{1 / 2} \approx 2.4 \mathrm{~h}\right)$. As mentioned above, the proposed mechanism involves dissociation of $\mathrm{PMe}_{3}$ to create an open coordination site, and coordination of a C-D bond of the hydrocarbon. The addition of $\mathrm{PMe}_{3}$ suppresses the rate of H/D exchange at the hydroxide ligand. Upon addition of non-coordinating base 2,6lutidine, the rate of $\mathrm{H} / \mathrm{D}$ exchange at the hydroxide ligand is decreased, which indicates that the acidity of the $\mathrm{C}-\mathrm{D}$ bond is likely enhanced upon coordination and internal $\mathrm{D}^{+}$is formed. The overall 1,2-addition process is completed by $\mathrm{D}^{+}$transfer to the available lone pair of electrons at the heteroatomic ligand. During the catalytic process, $\mathrm{TpRu}\left(\mathrm{PMe}_{3}\right)(\mathrm{OHD})\left(\mathrm{Ph}-d_{5}\right)$ is not observed.

DFT (B3LYP/CEP-31G(d)) calculations using the model $(\mathrm{Tab}) \mathrm{Ru}\left(\mathrm{PMe}_{3}\right)_{2}(\mathrm{OH})[\mathrm{Tab}=$ tris(azo)borate] indicate that the overall $\mathbf{C}-\mathrm{H}$ activation process $(\mathbf{A} \rightarrow \mathbf{E}$ in Scheme 1.16) 
for the $\mathrm{Ru}-\mathrm{OH}$ moiety and benzene is substantially endergonic by $18.4 \mathrm{kcal} / \mathrm{mol}$ at $298 \mathrm{~K}$, consistent with the lack of experimental observation of the intermediate $\mathrm{TpRu}\left(\mathrm{PMe}_{3}\right)(\mathrm{OHD})\left(\mathrm{Ph}-d_{5}\right)$ is likely a consequence of thermodynamics. The $\mathrm{C}-\mathrm{H}$ bond cleavage is calculated to occur by a four-center concerted process that resembles $\sigma$-bond metathesis, and calculations reveal that the transition state for $\mathrm{C}-\mathrm{H}$ bond cleavage gives a free energy barrier of $17.6 \mathrm{kcal} / \mathrm{mol}$ relative to $\eta^{2}$-benzene complex $\mathbf{C}$ (Scheme 1.16). The calculated free energy barrier for the transformation from $\eta^{2}$-benzene complex to the transition state $(\mathbf{C} \rightarrow \mathbf{D})$ is lower than the analogous free energy barrier for $\mathrm{C}-\mathrm{H}$ activation of benzene by the $\mathrm{Ru}-\mathrm{Me}$ bond of $\mathrm{TabRu}(\mathrm{CO})(\mathrm{Me})\left(\eta^{2}-\mathrm{C}_{6} \mathrm{H}_{6}\right)$, in which a lone pair is not available. ${ }^{98}$ Based on comparison of the four-centered interaction in the transition states of $(\mathrm{Tab}) \mathrm{Ru}\left(\mathrm{PH}_{3}\right)(\mathrm{OH})\left(\eta^{2}-\mathrm{C}_{6} \mathrm{H}_{6}\right)$ and $(\mathrm{Tab}) \mathrm{Ru}(\mathrm{CO})(\mathrm{Me})\left(\eta^{2}-\mathrm{C}_{6} \mathrm{H}_{6}\right)$, the transition state for $\mathrm{C}-\mathrm{H}$ activation by $\mathrm{Ru}-\mathrm{OH}$ might possess less oxidative character (closer to classic $\sigma-$ bond metathesis) than $\mathrm{Ru}-\mathrm{Me}$ because the calculated $\mathrm{Ru}{ }^{\cdots} \mathrm{H}$ distance in $\mathrm{Ru}-\mathrm{OH}$ complex is $0.3 \AA$ greater than that in $\mathrm{Ru}-\mathrm{Me}$ complex (Scheme 1.17). Additionally, the $\mathrm{Ru}-\mathrm{C}_{\text {phenyl }}$ length is $\sim 0.1 \AA$ greater and the $\mathrm{C}_{\text {phenyl }}-\mathrm{H}$ is $\sim 0.1 \AA$ shorter for $\mathrm{Ru}-\mathrm{OH}$ versus $\mathrm{Ru}-\mathrm{Me}$. Thus, the $\sigma$-bond metathesis mechanism for $\mathrm{Ru}-\mathrm{Me}$ complex can be better described as oxidative hydrogen migration because the interaction between the migrating $\mathrm{H}$ atom and metal is not negligible, with a $\mathrm{Ru}-\mathrm{H}$ length of $1.72 \AA$.
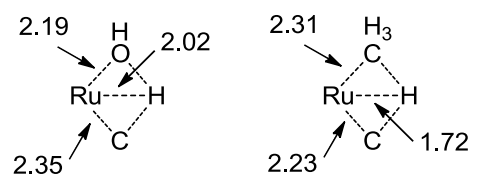

Scheme 1.17. Metric data $(\AA)$ for calculated transition states of benzene $\mathrm{C}-\mathrm{H}$ activation by $(\mathrm{Tab}) \mathrm{Ru}\left(\mathrm{PH}_{3}\right)(\mathrm{OH})\left(\eta^{2}-\mathrm{C}_{6} \mathrm{H}_{6}\right)$ and $(\mathrm{Tab}) \mathrm{Ru}(\mathrm{CO})(\mathrm{Me})\left(\eta^{2}-\mathrm{C}_{6} \mathrm{H}_{6}\right)$. 
The difference in calculated bond lengths likely indicates the facilitation of the $\mathrm{C}-\mathrm{H}$ activation reaction due to the presence of a lone pair on the heteroatomic ligand. It could be implied that the $s p^{3}$ orbitals of the methyl ligand of $\mathrm{Ru}-\mathrm{Me}$ complex overlap less substantially with the migrating $\mathrm{H}$ atom. In an Atoms In Molecules (AIM) analysis for the $\mathrm{C}-\mathrm{H}$ activation transition state of $\mathrm{Ru}-\mathrm{X}\left(\mathrm{X}=\mathrm{OH}, \mathrm{NH}_{2}\right)$, four bond-critical points $(\mathrm{M}-\mathrm{X}, \mathrm{X}-\mathrm{H}, \mathrm{C}-\mathrm{H}$, and $\mathrm{M}-\mathrm{C})$ as well as a ring-critical point implying a four-member ring transition state were found. ${ }^{74}$ However, a bond-critical point between the metal and migrating $\mathrm{H}$ atom was not found. In contrast, for the $\mathrm{Ru}-\mathrm{Me}$ complex, a bond-critical point between the metal and the migrating $\mathrm{H}$ atom was found, but a ring-critical point was missing in the AIM analysis of the $\mathrm{C}-\mathrm{H}$ activation transition state of $\mathrm{Ru}-\mathrm{Me}$. The AIM results suggest a change in nature of $\mathrm{C}-\mathrm{H}$ activation by introducing the lone pair on the heteroatom.

Periana et al. reported benzene $\mathrm{C}-\mathrm{H}$ activation with $\operatorname{Ir}(\mathrm{III})-\mathrm{OMe}$ and $-\mathrm{OH}$ complexes. $^{69-71}(\text { acac- } O, O)_{2} \operatorname{Ir}(\mathrm{L})(\mathrm{X}) \quad\left(\right.$ acac- $O, O=\kappa^{2}-\mathrm{O}, \mathrm{O}$-acetylacetone; $\mathrm{L}=\mathrm{OMe}$, pyridine, $\mathrm{X}=\mathrm{OMe} ; \mathrm{L}=$ pyridine, $\mathrm{X}=\mathrm{OH}$ ) activate the $\mathrm{C}-\mathrm{H}$ bond of benzene at $160-$ $180{ }^{\circ} \mathrm{C}$, yielding an Ir-phenyl complex and water or methanol (Scheme 1.18). The first step of the proposed activation pathway for $(\operatorname{acac}-O, O)_{2} \operatorname{Ir}(\mathrm{L})(\mathrm{X})$ is also the dissociation of ancillary ligand, giving an open coordination site $(\mathrm{L}=$ pyridine, $\mathrm{X}=\mathrm{OH}$ in Scheme 1.19). Unlike the activation pathway for $\mathrm{TpRu}\left(\mathrm{PMe}_{3}\right)_{2}(\mathrm{OH})$, the open coordination site is trans to the heteroatom ligand, and the complex must undergo a structural rearrangement to place the heteroatom ligand cis to the open coordination site. Subsequent benzene $\mathrm{C}-\mathrm{H}$ 
bond coordination followed by 1,2-CH-addition across the Ir-heteroatom bond results in the formation of water as well as the Ir-phenyl complex.

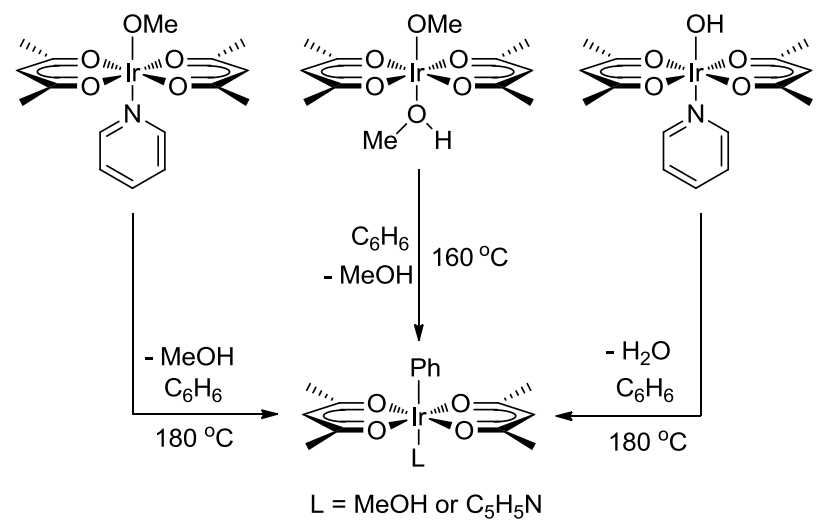

Scheme 1.18. Benzene $\mathrm{C}-\mathrm{H}$ activation by O-donor $\mathrm{Ir}(\mathrm{III})$-heteroatom complexes.

DFT calculations (B3LYP/LACVP** with ZPE and solvent correction) were performed on the proposed $\mathrm{C}-\mathrm{H}$ activation mechanism and the results are shown in Scheme 1.19. Experimental and theoretical KIEs suggest that the reaction proceeds via rate-determining formation of an arene complex followed by fast $\mathrm{C}-\mathrm{H}$ cleavage. In accord with the experimental observation of (acac- $O, O)_{2} \operatorname{Ir}($ pyridine)(phenyl) and water, the calculations reveal that the overall process is thermodynamically favorable $(\Delta G=-$ $6.8 \mathrm{kcal} / \mathrm{mol})$. 


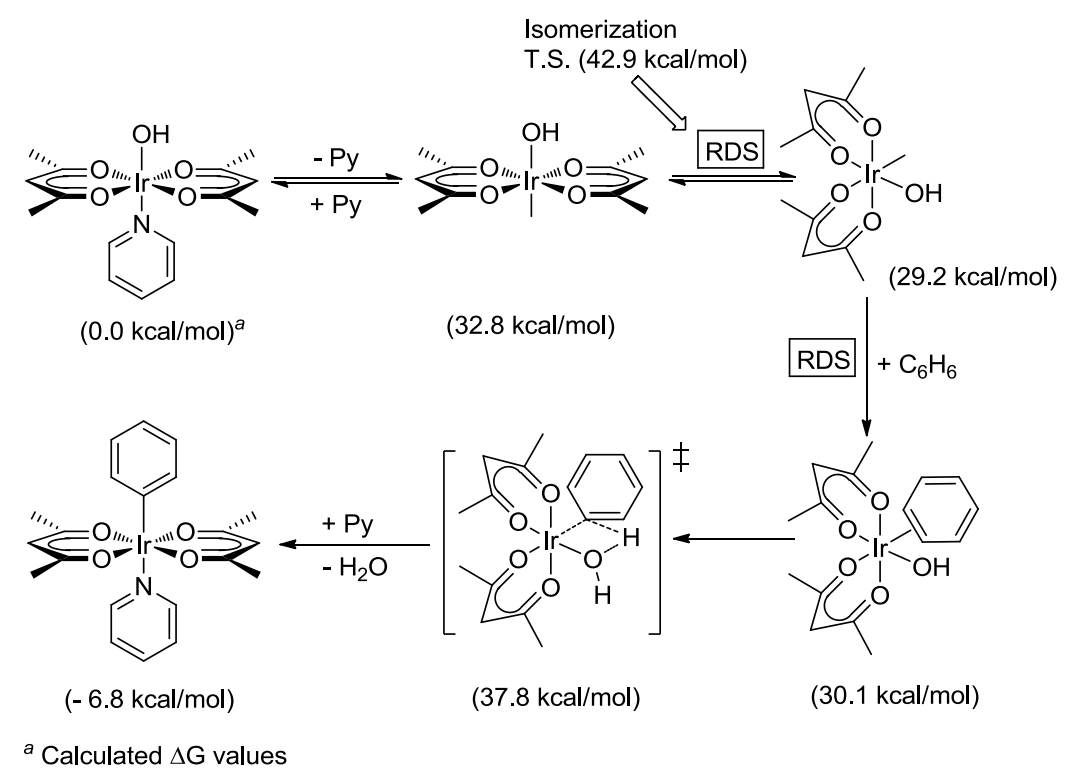

Scheme 1.19. Proposed mechanism for benzene $\mathrm{C}-\mathrm{H}$ activation by $(\operatorname{acac}-O, O)_{2}-$ $\operatorname{Ir}($ pyridine $)(\mathrm{OH})$.

The mechanism for the $\mathrm{C}-\mathrm{H}$ activation reaction has been described by Goddard, Periana et al. as an "internal electrophilic substitution (IES)",71 on the basis of orbital changes and predicted reactivity, which is akin to the "intramolecular proton transfer" discussed by our group. ${ }^{99}$ In the IES mechanism, the $\mathrm{X}-\mathrm{H}$ bond is formed from the lone pair of the heteroatom, and the $\mathrm{M}-\mathrm{X}$ bond is transformed into a dative lone pair bond. The migrating $\mathrm{H}$ atom must cross an orbital nodal plane in the IES mechanism. In the $\sigma-$ bond metathesis mechanism, the formation of $\mathrm{X}-\mathrm{H}$ bond is based on the same orbital as the $\mathrm{M}-\mathrm{X}$ bond and the migrating $\mathrm{H}$ atom does not cross a nodal plane. It is likely that the electrophilicity of metal center is important in the $\mathrm{C}-\mathrm{H}$ bond coordination and the $\mathrm{C}-\mathrm{H}$ bond activation by generating a positively charged hydrogen. Preliminary calculations on the model complex $\operatorname{Ir}\left(\mathrm{CH}_{3}\right)_{2}\left(\mathrm{NR}_{3}\right)_{2}(\mathrm{OH})\left(\mathrm{CH}_{4}\right)(\mathrm{R}=\mathrm{H}$ or $\mathrm{F})$ reveal that replacing the $\mathrm{NH}_{3}$ ligands with weaker electron-donating $\mathrm{NF}_{3}$ ligands reduces the barrier by $6.8 \mathrm{kcal} / \mathrm{mol}$, 
addressing the importance of electrophilicity of the metal center. These results suggest that enhancement of metal electrophilicity in combination with high $d$-count (inhibition of lone pair donation to metal via $d_{\pi}-p_{\pi}$ repulsion) is advantageous in the development of complexes that facilitate $\mathrm{C}-\mathrm{H}$ activation by 1,2 -addition across $\mathrm{M}-\mathrm{X}$ bond.

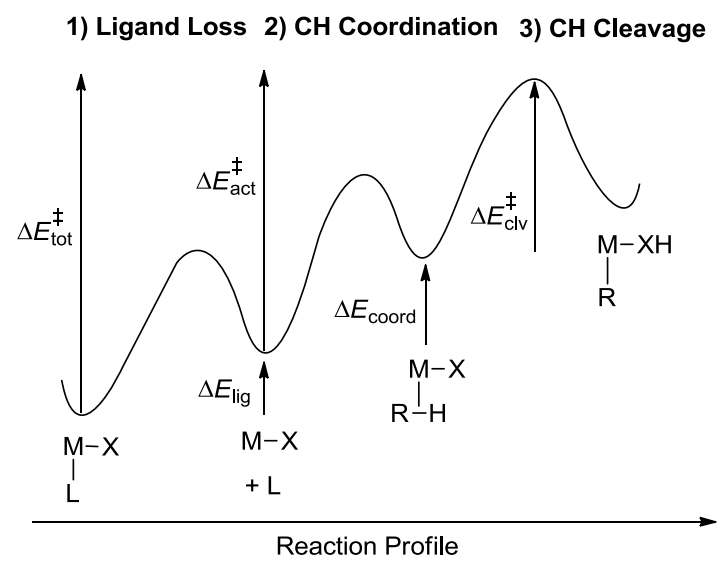

Scheme 1.20. General $\mathrm{C}-\mathrm{H}$ activation reaction profile via 1,2 -addition across $\mathrm{M}-\mathrm{X}$ bond.

Recently, Gunnoe, Ess, et al. addressed the importance of a lone pair and $d_{\pi}-p_{\pi}$ repulsion using density functional analysis (B3LYP, M06, and X3LYP) of (acac$O, O)_{2} \mathrm{M}(\mathrm{X})$ and $\mathrm{TpM}(\mathrm{L}) \mathrm{X}\left(\mathrm{M}=\mathrm{Ir}, \mathrm{Ru}, \mathrm{Os}\right.$, and $\mathrm{Rh} ; \mathrm{X}=\mathrm{Me}, \mathrm{OH}, \mathrm{OMe}, \mathrm{NH}_{2}$, and $\left.\mathrm{NMe}_{2}\right)$ systems for methane $\mathrm{C}-\mathrm{H}$ activation. ${ }^{100}$ The activation reaction sequence (shown in Scheme 1.20) involves three steps: (1) ligand dissociation to create an open coordination site; (2) hydrocarbon coordination; and (3) $\mathrm{C}-\mathrm{H}$ bond cleavage. Upon dissociation of an ancillary ligand, the calculations predict that the M-alkyl species typically retain a square-pyramidal geometry (octahedral geometry with an open coordination site at the sixth position) while the $\mathrm{M}$-heteroatom species adopt a more stable distorted trigonalbipyramidal like structure, which is due to the increasing HOMO-LUMO gap by substituting $\mathrm{X}=\mathrm{CH}_{3}$ with $\mathrm{X}=\mathrm{OR} / \mathrm{NR}_{2}$. For the $\mathrm{M}$-heteroatom species, the $\mathrm{LUMO}$ is an 
antibonding combination of the metal $d_{\mathrm{z} 2}$ and X $p$ orbitals, and the HOMO is a $d_{\pi}-p_{\pi}$ antibonding interaction. In the distorted geometry, the $d_{\mathrm{z} 2}-p$ antibonding interactions are more destabilizing than the $d_{\pi}-p_{\pi}$ antibonding interaction and the HOMO-LUMO gap increases. The distorted geometry is ultimately favorable because the $d_{\pi}-p_{\pi}$ combination becomes more stable. This geometry change is the same as the cis-ligand effect for $\mathrm{ML}_{5}$ complexes that is previously discussed by Eisenstein, Hall et al. ${ }^{101-103}$

Among the transition state structures for $\mathrm{C}-\mathrm{H}$ bond activation, methyl complexes typically have a kite-like structure whereas the heteroatomic complexes have a rightangle structure (shown in Scheme 1.21). A direct bonding interaction exists in the kitelike structure between the metal and $\mathrm{H}$ atoms. This metal- $\mathrm{H}$ interaction is less pronounced in complexes that possess lone pair on X ligands. The lone pair on X ligands leads to a relatively strong $\mathrm{X}-\mathrm{H}$ interaction, which will mitigate the metal- $\mathrm{H}$ interaction.

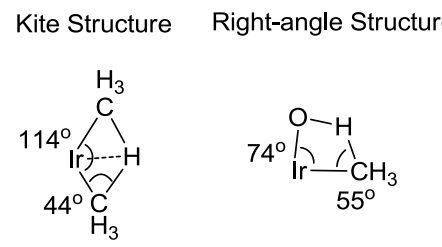

Scheme 1.21. Comparison of transition state structures for methane $\mathrm{C}-\mathrm{H}$ bond activation by $(\text { acac- } O, O)_{2} \mathrm{M}(\mathrm{Me})$ and $(\text { acac- } O, O)_{2} \mathrm{M}(\mathrm{OH})$.

Because of the structural distortion upon loss of ancillary ligands, there is an energetic penalty to revert back to octahedral-like geometry in preparation for hydrocarbon coordination and $\mathrm{C}-\mathrm{H}$ bond cleavage. As a result, the activation barrier $\Delta E^{\ddagger}$ act (the sum of coordination and cleavage steps) is higher for $\mathrm{X}=\mathrm{OR} / \mathrm{NR}_{2}$ than $\mathrm{X}=\mathrm{CH}_{3}$. By taking the barrier for ligand dissociation into consideration, the total activation barriers $\Delta E_{\text {tot }}^{\ddagger}$ (the sum of ligand dissociation and $\Delta E^{\ddagger}$ act $)$ become lower for $\mathrm{X}=\mathrm{OR} / \mathrm{NR}_{2}$ than $\mathrm{X}=\mathrm{Me}$. The 
different trends between $\Delta E_{\text {tot }}^{\ddagger}$ and $\Delta E_{\text {act }}^{\ddagger}$ are likely due to the smaller binding energy of ancillary ligand and easier formation of coordinatively unsaturated species that is essential for hydrocarbon coordination when $\mathrm{X}=\mathrm{OR} / \mathrm{NR}_{2}$. These results indicate that the donating ability ( $d_{z 2}-p$ interactions) of the $\mathrm{X}$ ligands are more predominating, compared to the $d_{\pi}-p_{\pi}$ repulsions, in destabilizing the LUMO energy and lowering $\Delta E_{\text {tot }}^{\ddagger}$ through decreasing the ancillary ligand binding energy. The lone pair from the heteroatomic ligands is more important for ground-state effects than transition-state effects. A general trend in the relative activation barrier for $\mathrm{C}-\mathrm{H}$ activation by $\mathrm{M}-\mathrm{R}$ vs. $\mathrm{M}-\mathrm{X}$ complexes probably does not exist.

\subsection{Thesis outline}

The development of homogeneous catalysts for low-temperature, selective, direct hydrocarbon functionalization would constitute a major advanve in energy utilization. For catalytic hydrocarbon partial oxidation, $\mathrm{C}-\mathrm{H}$ bond activation is a key step. As discussed above, late transition metal complexes provide potentially advantages on catalysis. We are particularly interested in $\mathrm{C}-\mathrm{H}$ activation via 1,2 -addition across $\mathrm{M}-\mathrm{X}$ bonds. However, there are only a limited number of examples of such reactions. Alkane activation reaction by these complexes still remains unrealized.

From the discussion above, we know that high d-count electrophilic metal centers and formation of coordinatively unsaturated species are important in $\mathrm{M}-\mathrm{X}$ type $\mathrm{C}-\mathrm{H}$ activation. For the previously mentioned $\mathrm{TpRu}\left(\mathrm{PMe}_{3}\right)_{2}(\mathrm{X})$, some drawbacks impede its further study and application. The work described herein focuses on the synthesis of cationic $\mathrm{Ru}(\mathrm{II})$ complexes designed to solve the drawbacks of the current $\mathrm{Tp}-\mathrm{Ru}$ systems. 
A better $\mathrm{Ru}(\mathrm{II})$-heteroatom system might be developed by making the open coordination site more easily accessible and the metal more electrophilic, which could facilitate $\mathrm{C}-\mathrm{H}$ activation.

During our investigation of better structures for $\mathrm{C}-\mathrm{H}$ bond activation, it is commonly found that dimerization competes with $\mathrm{C}-\mathrm{H}$ bond coordination in the presence of a lone pair and a vacant coordination site upon ligand dissociation, by which a relatively stable dimeric complex will be formed (Scheme 1.22). It is difficult to coordinate a $\mathrm{C}-\mathrm{H}$ bond from this dimeric complex due to an inaccessible open coordination site. Thus, prevention of dimerization after ligand dissociation is also an important issue with respect to future exploration. A feasible strategy might be the application of bulkier supporting ligands, making the dimerization sterically unfavorable. The introduction of phosphine or phosphite ligands with large cone angles would likely prohibit the dimerization. In addition, a more electronegative metal center would also help to prevent dimerization.

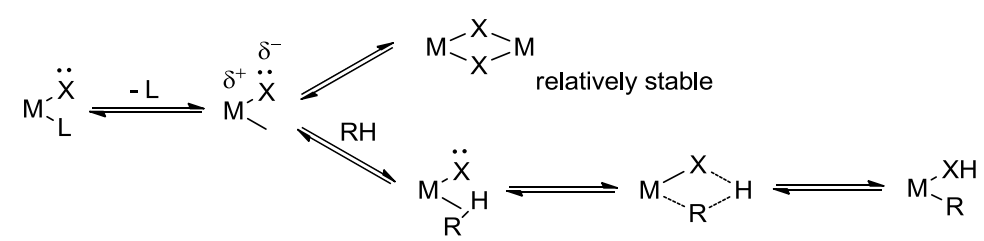

Scheme 1.22. Two common reaction pathways for $M-X$ complexes with an open coordination site: dimerization and $\mathrm{C}-\mathrm{H}$ bond coordination. 


\section{Chapter 2}

\subsection{Rationale}

My goal is to synthesize $\mathrm{Ru}(\mathrm{II})$ complexes that can facilitate $\mathrm{C}-\mathrm{H}$ activation of hydrocarbons via 1,2-addition across Ru-heteroatom bonds $(\mathrm{Ru}-\mathrm{X})$ and examine this process. While $\mathrm{TpRu}\left(\mathrm{PMe}_{3}\right)_{2} \mathrm{X}(\mathrm{X}=\mathrm{OH}, \mathrm{NHPh}$ or $\mathrm{Me})$ complexes activate benzene $\mathrm{C}-\mathrm{H}$ bonds (see Chapter 1), studies of these reactions are complicated by the strongly coordinating $\mathrm{PMe}_{3}$ ligands, which must dissociate to coordinate benzene. Previous attempts to replace $\mathrm{PMe}_{3}$ with more weakly coordinating ligands were unsuccessful. Our hope was to prepare charge-neutral $\mathrm{Ru}(\mathrm{II})$ complexes $\mathrm{L}_{3} \mathrm{Ru}\left(\mathrm{L}^{\prime}\right)(\mathrm{X})(\mathrm{Cl})(\mathrm{X}=\mathrm{OR}$, NHR) and to exchange chloride with a non-coordinating anion to give coordinatively unsaturated 16-electron complexes $\left[\mathrm{L}_{3} \mathrm{Ru}\left(\mathrm{L}^{\prime}\right)(\mathrm{X})\right]^{+}$. If needed, these cations could be trapped with weakly coordinating ligands (e.g., THF, $\mathrm{CF}_{3} \mathrm{CH}_{2} \mathrm{OH}, \mathrm{C}_{5} \mathrm{~F}_{5} \mathrm{~N}, \mathrm{Et}_{2} \mathrm{O}$ ), which should provide more facile access to 16 -electron reactive species than $\mathrm{TpRu}\left(\mathrm{PMe}_{3}\right)_{2} \mathrm{X}$. In addition, as discussed in Chapter 1, the cationic charge in the intermediate $\left[\mathrm{L}_{3} \mathrm{Ru}\left(\mathrm{L}^{\prime}\right)(\mathrm{X})\right]^{+}$ might facilitate $\mathrm{C}-\mathrm{H}$ activation.

The $\quad \mathrm{d}^{6} \quad$ octahedral $\quad \mathrm{Ru}(\mathrm{II}) \quad$ complexes, $\quad\left[\kappa^{3}-\mathrm{C}(\mathrm{pz})_{4}\right] \mathrm{Ru}(\mathrm{L})(\mathrm{X})(\mathrm{Cl}) \quad\left[\mathrm{C}(\mathrm{pz})_{4}=\right.$ tetra(pyrazolyl)methane; $\left.\mathrm{X}=\mathrm{NHPh}, \mathrm{OH}, \mathrm{OPh}, \mathrm{OMe} ; \mathrm{L}=\mathrm{P}\left(\mathrm{OCH}_{2}\right)_{3} \mathrm{CEt}\right]$, are the target precursors to coordinatively unsaturated species $\left\{\left[\kappa^{3}-\mathrm{C}(\mathrm{pz})_{4}\right] \mathrm{Ru}(\mathrm{L})(\mathrm{X})\right\}^{+}$to activate $\mathrm{C}-\mathrm{H}$ bonds (Scheme 2.1). For six-coordinate complexes, six electrons in three filled $d \pi$ orbitals prevent $\pi$-donation from the ligand $\mathrm{X}$, which can enhance reactivity by making the ligand $\mathrm{X}$ more basic than complexes with $\mathrm{X}$-to-metal $\pi$-donation. ${ }^{58,89,90} \mathrm{By}$ incorporation of a weaker donor $\mathrm{P}\left(\mathrm{OCH}_{2}\right)_{3} \mathrm{CEt}$ ligand than $\mathrm{PMe}_{3}$, and the neutral 
tridentate $\mathrm{C}(\mathrm{pz})_{4}$ ligand, the electrophilicity of metal should be enhanced compared with $\mathrm{TpRu}\left(\mathrm{PMe}_{3}\right)_{2} \mathrm{X}$ complexes.

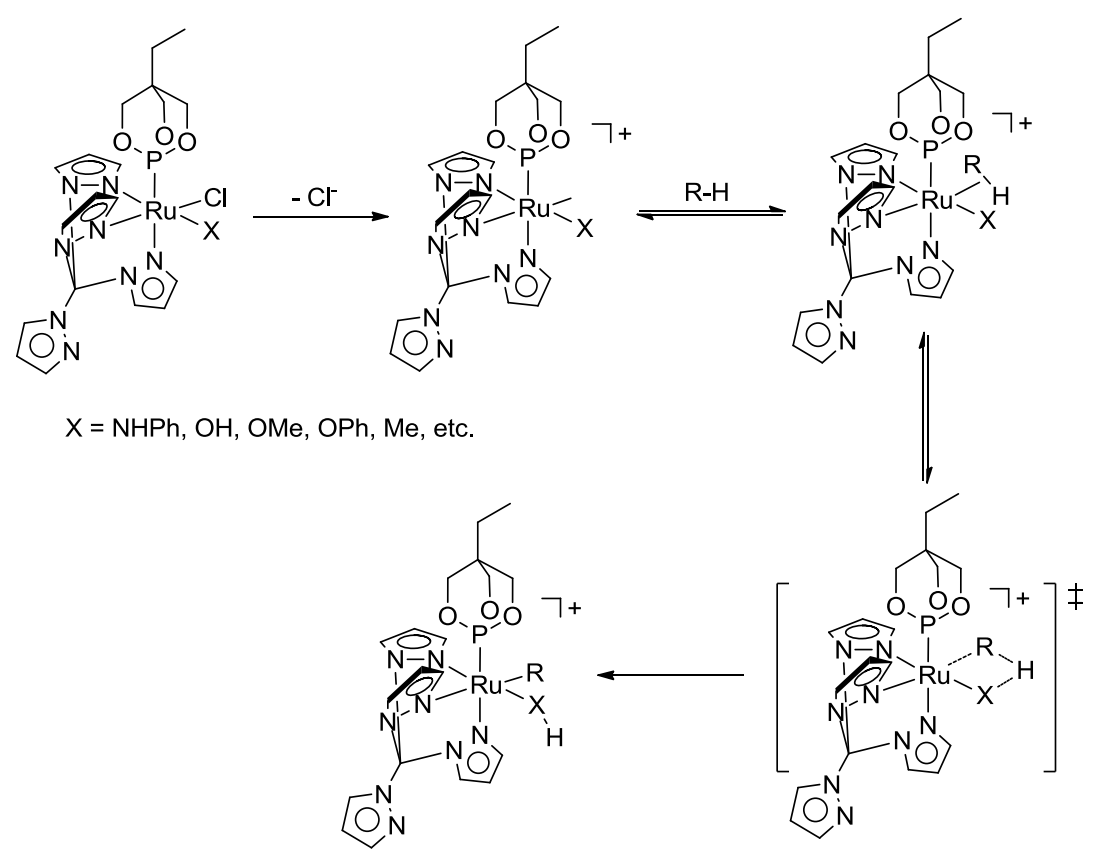

Scheme 2.1. $\mathrm{C}-\mathrm{H}$ bond activation by proposed $\mathrm{Ru}(\mathrm{II})$ system.

After the preparation and successful isolation of $\left[\kappa^{3}-\mathrm{C}(\mathrm{pz})_{4}\right] \mathrm{Ru}(\mathrm{L})(\mathrm{X})(\mathrm{Cl})$, the fivecoordinate species $\left\{\left[\kappa^{3}-\mathrm{C}(\mathrm{pz})_{4}\right] \mathrm{Ru}(\mathrm{L})(\mathrm{X})\right\}^{+}$might be accessed more easily than $\mathrm{TpRu}\left(\mathrm{PMe}_{3}\right)_{2} \mathrm{X}$ by removal of the halide using halide abstraction reagents. Assays for stoichiometric $\mathrm{C}-\mathrm{H}$ activation by $\left\{\left[\kappa^{3}-\mathrm{C}(\mathrm{pz})_{4}\right] \mathrm{Ru}\left[\mathrm{P}\left(\mathrm{OCH}_{2}\right)_{3} \mathrm{CEt}\right](\mathrm{X})\right\}^{+}$will be performed. Variation of $\mathrm{X}$ ligands between $\mathrm{OH}, \mathrm{OR}, \mathrm{NHR}$ and Me will allow us to determine the influence of its identity on the activation barrier for 1,2-CH-addition. Also, by replacing the bicyclic phosphite ligand with various phosphites and phospines, variation of metal electron density could be achieved to provide insight into the impact of ancillary ligand on activation barriers. Due to its thermodynamically unfavorable nature, the $\mathrm{Ru}-$ hydrocarbyl intermediate was not directly observed along the $\mathrm{C}-\mathrm{H}$ activation process by 
$\mathrm{TpRu}\left(\mathrm{PMe}_{3}\right)_{2} \mathrm{X}$ systems. ${ }^{67,68}$ The $\mathrm{C}-\mathrm{H}$ activation by $\left\{\left[\kappa^{3}-\mathrm{C}(\mathrm{pz})_{4}\right] \mathrm{Ru}(\mathrm{L})(\mathrm{X})\right\}^{+}$might be thermodynamically favorable and Ru-hydrocarbyl complexes $\left\{\left[\kappa^{3}-\right.\right.$ $\left.\left.\mathrm{C}(\mathrm{pz})_{4}\right] \mathrm{Ru}(\mathrm{L})(\mathrm{XH})(\mathrm{R})\right\}^{+}$might be directly observed. Range of hydrocarbon that can be activated and the selectivity toward different $\mathrm{C}-\mathrm{H}$ bonds will be probed. A primary goal is the discovery of complexes with $\mathrm{M}-\mathrm{X}$ bond that are capable of alkane $\mathrm{C}-\mathrm{H}$ activation.

\subsection{Results and discussion}

\subsubsection{Synthetic efforts}

My project began with the synthesis of tetra(pyrazolyl)methane $\left[\mathrm{C}(\mathrm{pz})_{4}(\mathbf{1})\right]$. The synthesis of $\mathrm{C}(\mathrm{pz})_{4}$ via displacement of all $\mathrm{Cl}$ atoms on carbon tetrachloride by pyrazole has been reported. ${ }^{104}$ The work-up procedures are time-consuming and the yield is low $(\sim 1 \%)$. I have shortened the work-up steps and improved the isolation based on the solubility differences between $\mathrm{C}(\mathrm{pz})_{4}$ and by-products in diethyl ether. A mixture containing $\mathrm{C}(\mathrm{pz})_{4}$ and many other by-products is obtained by heating pyrazole in $\mathrm{CCl}_{4}$ overnight in the presence of $\mathrm{K}_{2} \mathrm{CO}_{3} / \mathrm{KOH}$ and phase-transfer catalyst $\left[(\mathrm{Bu})_{4} \mathrm{~N}\right]\left[\mathrm{HSO}_{4}\right]$. $\mathrm{C}(\mathrm{pz})_{4}$ can be isolated in $\sim 4 \%$ yield by concentrating the mixture and washing the residue with cold diethyl ether.

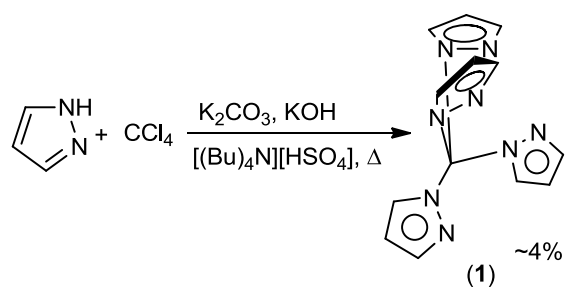

Scheme 2.2. Synthesis of tetra(pyrazolyl)methane (1). 
Compound 1 reacts with one equivalent of $\mathrm{RuCl}_{2}\left(\mathrm{PPh}_{3}\right)_{3}$ in refluxing toluene to afford $\left[\kappa^{3}-\mathrm{C}(\mathrm{pz}) 4\right] \mathrm{RuCl}_{2}\left(\mathrm{PPh}_{3}\right)(\mathbf{2})$ in $\sim 80 \%$ isolated yield (Scheme 2.3). The product, which is not soluble in toluene, can easily be isolated from the reaction mixture by filtration.

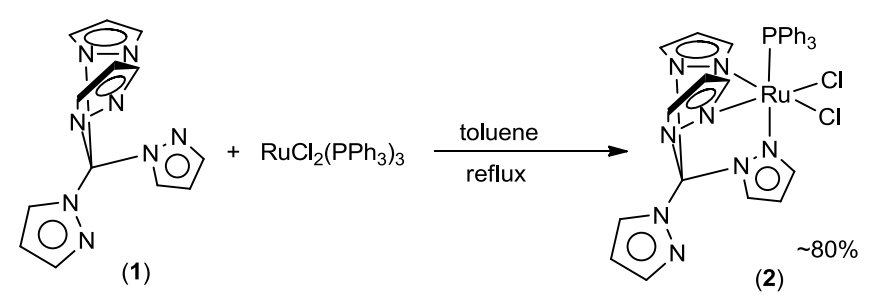

Scheme 2.3. Synthesis of $\left[\kappa^{3}-\mathrm{C}(\mathrm{pz}) 4\right] \mathrm{RuCl}_{2}\left(\mathrm{PPh}_{3}\right)$ (2).

Characterization of complex 2 by ${ }^{1} \mathrm{H}$ NMR spectroscopy in chloroform- $d_{1}$ indicates 9 resonances in the downfield $\mathrm{C}(\mathrm{pz})_{4}$ region (Figure 2.1) consistent with the $\mathrm{C}_{\mathrm{s}}$ molecular symmetry ( 3 resonances from two equivalent pyrazolyl rings, 3 resonances from one unique coordinated pyrazolyl ring and 3 resonances from one free pyrazolyl ring). In addition, ${ }^{31} \mathrm{P}$ and ${ }^{13} \mathrm{C}$ NMR spectroscopy indicate isolation of clean product (Figure 2.2 and Figure 2.3, respectively). 


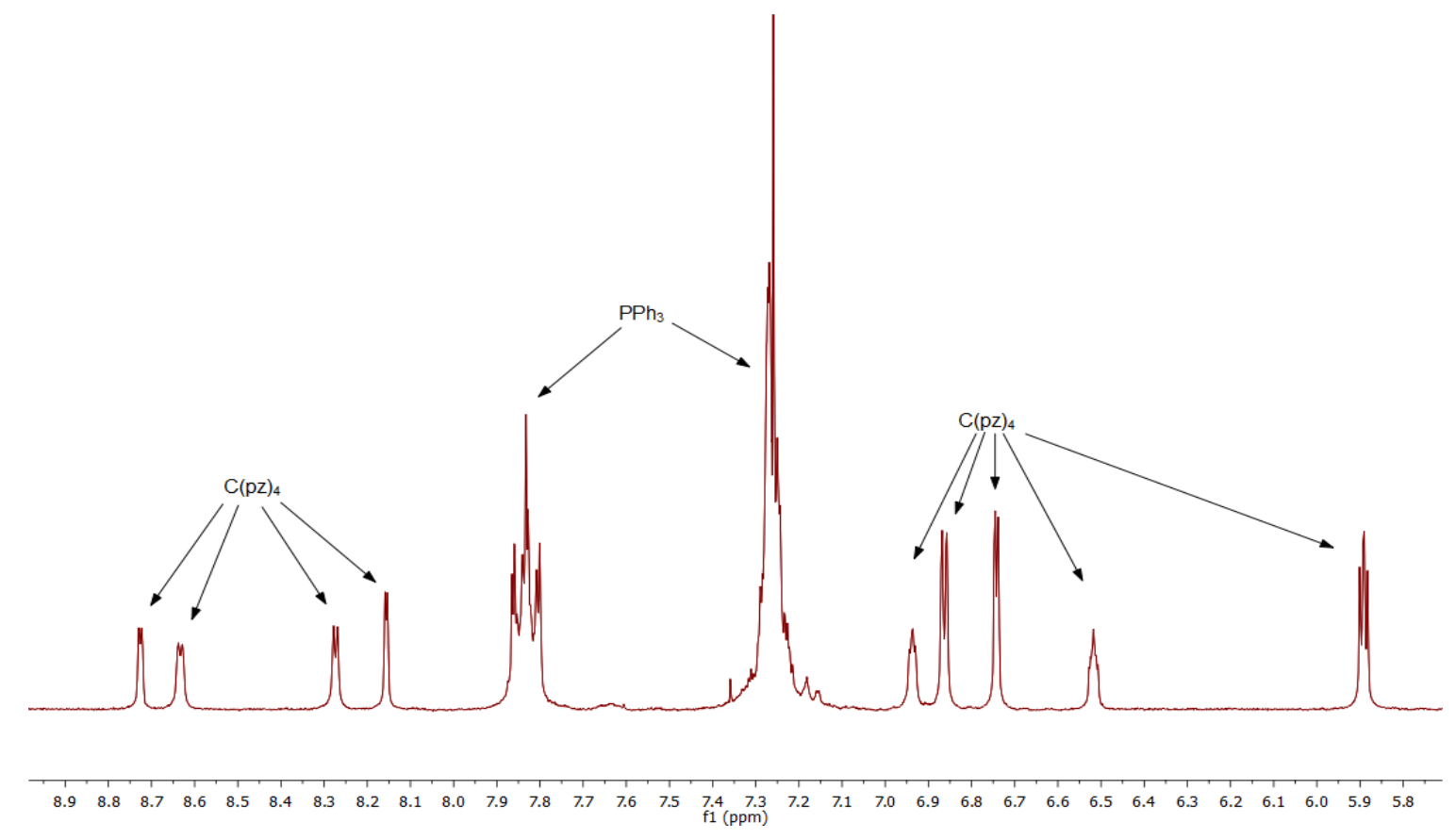

Figure 2.1. ${ }^{1} \mathrm{H}$ NMR spectrum (downfield region) of $\left[\kappa^{3}-\mathrm{C}(\mathrm{pz})_{4}\right] \mathrm{RuCl}_{2}\left(\mathrm{PPh}_{3}\right)$ (2) in $\mathrm{CDCl}_{3}$.

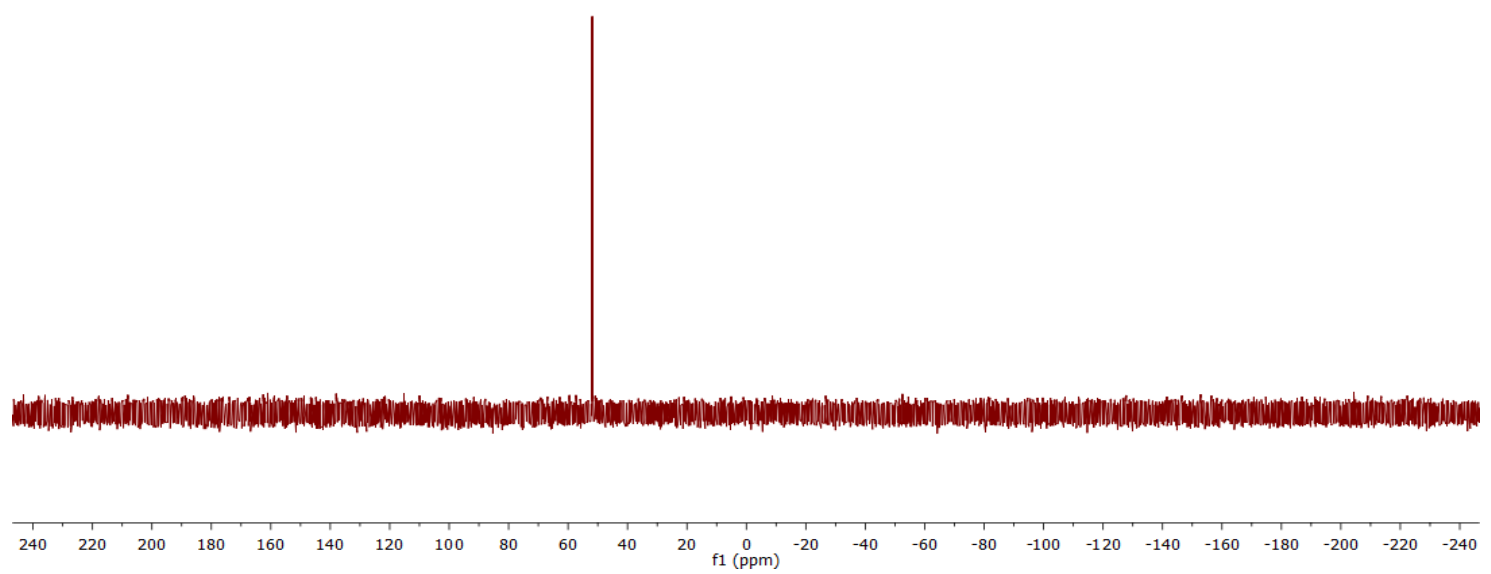

Figure 2.2. ${ }^{31} \mathrm{P}$ NMR spectrum of $\left[\kappa^{3}-\mathrm{C}(\mathrm{pz})_{4}\right] \mathrm{RuCl}_{2}\left(\mathrm{PPh}_{3}\right)(2)$ in $\mathrm{CDCl}_{3}$. 


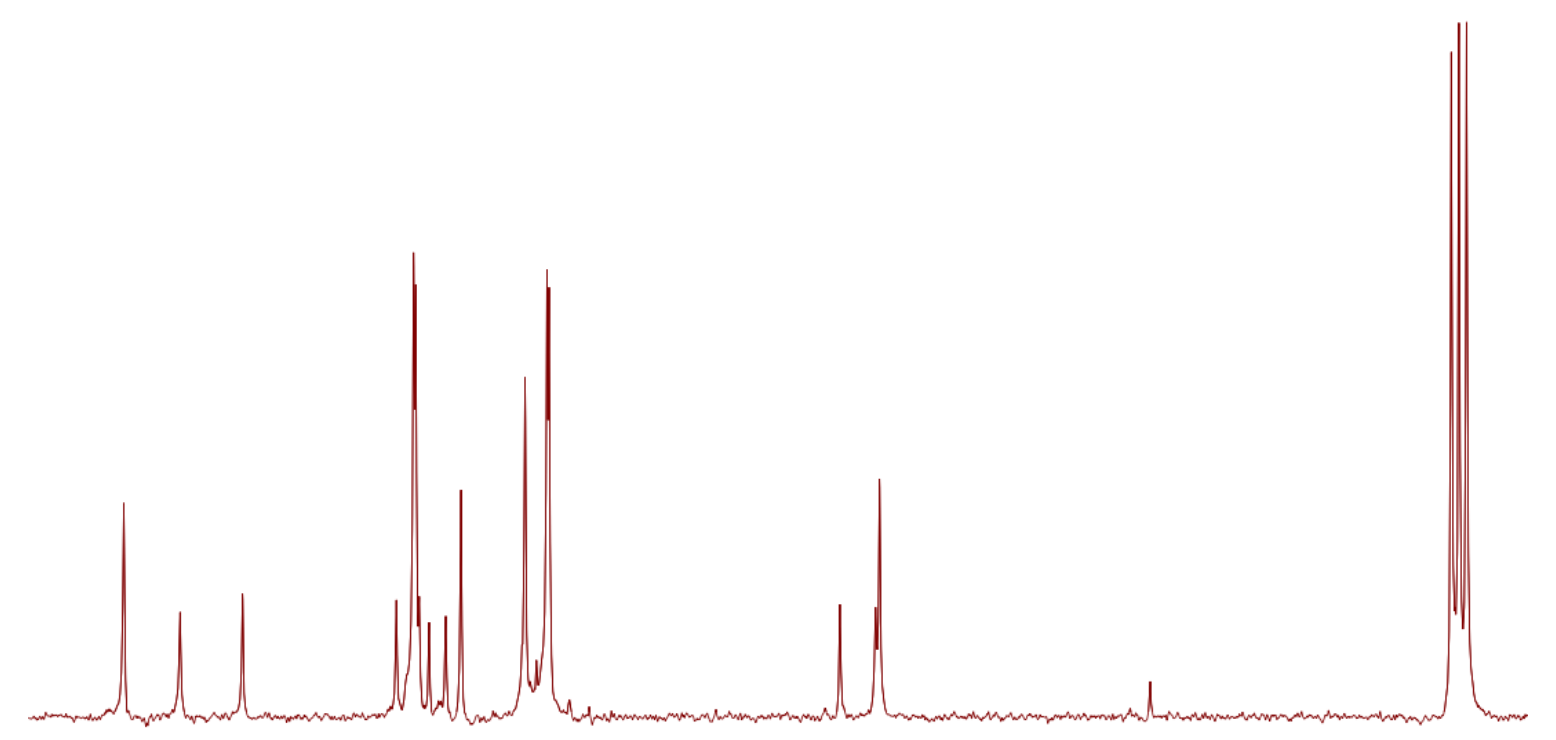

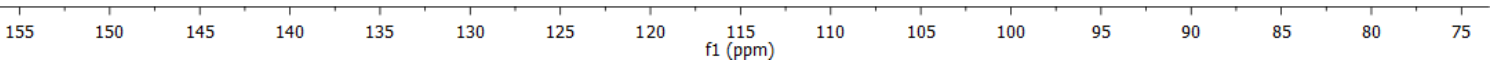

Figure 2.3. ${ }^{13} \mathrm{C} N M R$ spectrum of $\left[\kappa^{3}-\mathrm{C}(\mathrm{pz})_{4}\right] \mathrm{RuCl}_{2}\left(\mathrm{PPh}_{3}\right)(2)$ in $\mathrm{CDCl}_{3}$.

$\mathrm{PPh}_{3}$ is not a good ligand to utilize in $\mathrm{C}-\mathrm{H}$ activation studies due to the possibility of orthometallation. Thus, we sought to replace $\mathrm{PPh}_{3}$ with a ligand that cannot undergo cyclometallation. $\left[\kappa^{3}-\mathrm{C}(\mathrm{pz})_{4}\right] \mathrm{Ru}(\mathrm{Cl})_{2}\left[\mathrm{P}\left(\mathrm{OCH}_{2}\right)_{3} \mathrm{CEt}\right](3)$ is prepared by replacing the $\mathrm{PPh}_{3}$ of 2 with 4-ethyl-2,6,7-trioxa-1-phosphabicyclo[2.2.2] octane (Scheme 2.4). Refluxing a solution of 2 with five equivalents of $\mathrm{P}\left(\mathrm{OCH}_{2}\right)_{3} \mathrm{CEt}$ in chloroform affords a mixture of mono- and di-substituted phosphite complexes ( $\mathbf{3}^{\prime}$ and $\mathbf{3}$ in Scheme 2.4). The mixture is completely converted to $\mathbf{3}$ by refluxing in a chloroform solution in the absence of phosphite. 


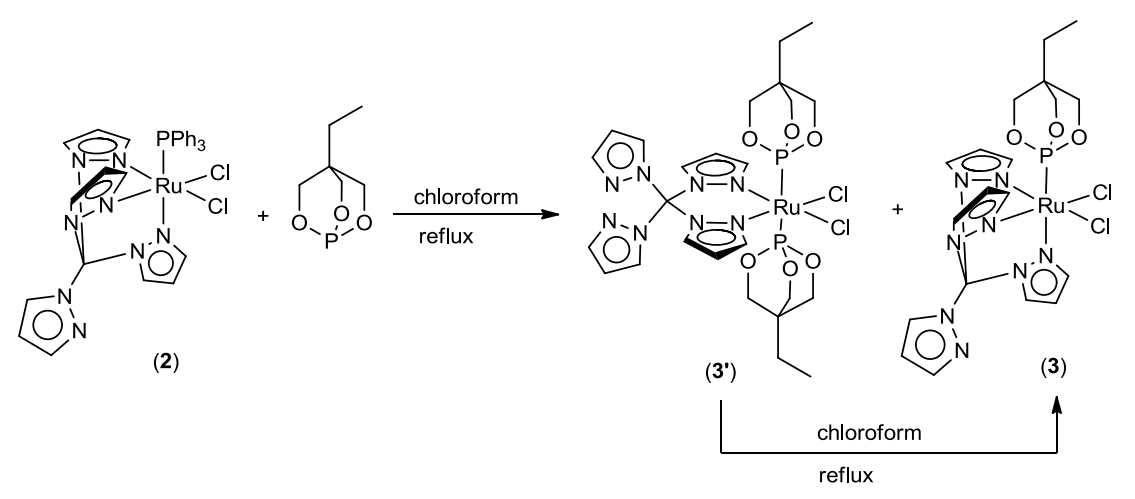

Scheme 2.4. Synthesis of $\left[\kappa^{3}-\mathrm{C}(\mathrm{pz})_{4}\right] \mathrm{RuCl}_{2}\left[\mathrm{P}\left(\mathrm{OCH}_{2}\right)_{3} \mathrm{CEt}\right](3)$.

The nine resonances of $\mathrm{C}(\mathrm{pz})_{4}$ in the ${ }^{1} \mathrm{H}$ NMR spectrum indicate that complex 3 retains $\mathrm{C}_{\mathrm{s}}$ molecular symmetry (Figure 2.4 ). In the ${ }^{1} \mathrm{H}$ NMR spectrum, a doublet $\left({ }^{3} J_{\mathrm{HP}}=4\right.$ $\mathrm{Hz}$ ) at $4.38 \mathrm{ppm}$ for the phosphite methylene bridges indicates the coordination of phosphite ligand (Figure 2.4). The appearance of a singlet for the phosphite ligand at $127.5 \mathrm{ppm}$ in the ${ }^{31} \mathrm{P}$ NMR spectrum (Figure 2.5) and disappearance of the singlet for the $\mathrm{PPh}_{3}$ ligand at $51.8 \mathrm{ppm}$ (Figure 2.2) indicate the replacement of $\mathrm{PPh}_{3}$ with $\mathrm{P}\left(\mathrm{OCH}_{2}\right)_{3} \mathrm{CEt}$. This complex was also characterized by ${ }^{13} \mathrm{C}$ NMR spectroscopy in nitromethane- $d_{3}$. The resulting spectrum indicates a clean product (Figure 2.6). 


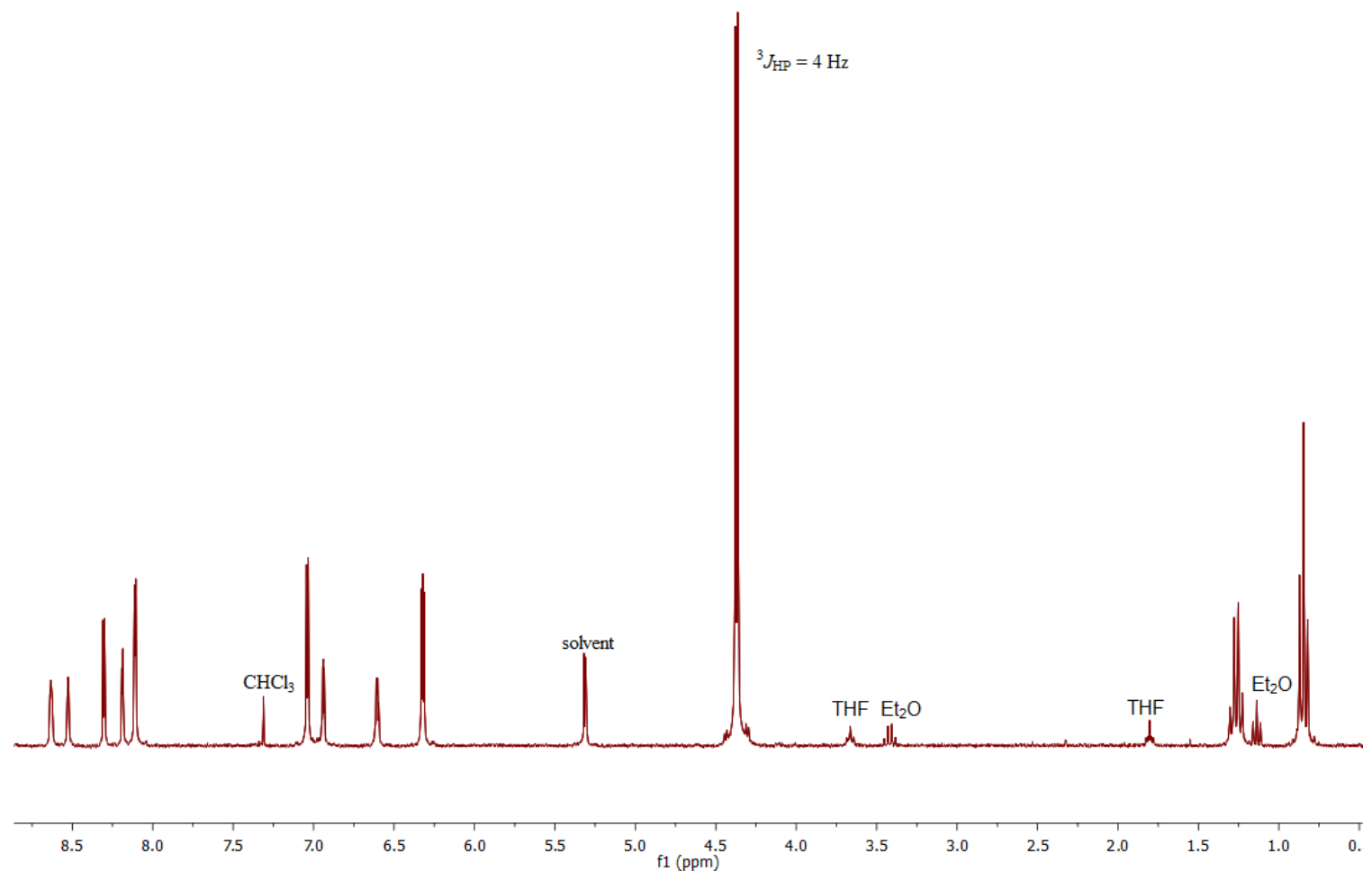

Figure 2.4. ${ }^{1} \mathrm{H}$ NMR spectrum of $\left[\kappa^{3}-\mathrm{C}(\mathrm{pz})_{4}\right] \mathrm{RuCl}_{2}\left[\mathrm{P}\left(\mathrm{OCH}_{2}\right)_{3} \mathrm{CEt}\right](3)$ in $\mathrm{CD}_{2} \mathrm{Cl}_{2}$.

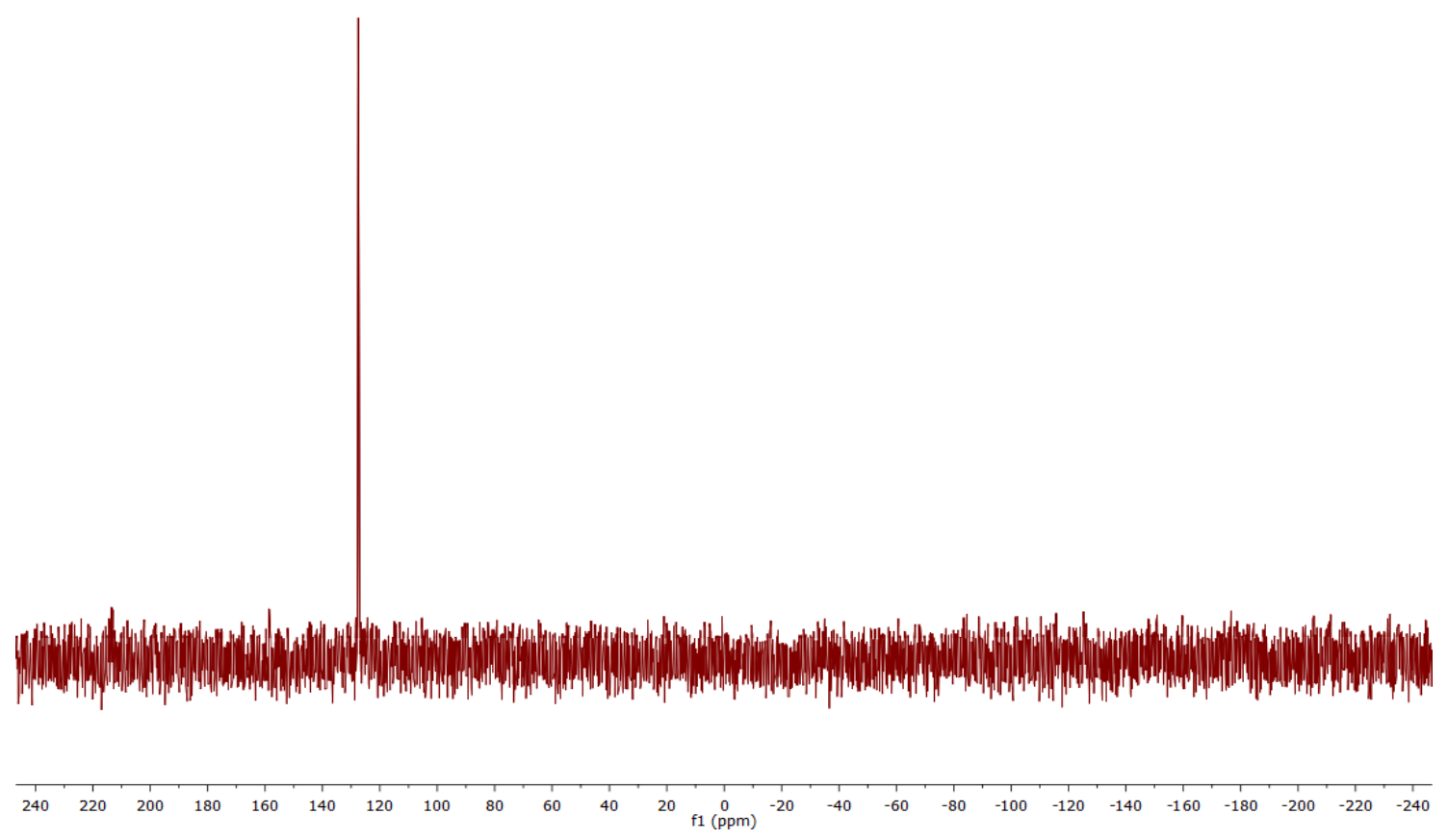

Figure 2.5. ${ }^{31} \mathrm{P} N M R$ spectrum of $\left[\kappa^{3}-\mathrm{C}(\mathrm{pz})_{4}\right] \mathrm{RuCl}_{2}\left[\mathrm{P}\left(\mathrm{OCH}_{2}\right)_{3} \mathrm{CEt}\right](3)$ in $\mathrm{CD}_{2} \mathrm{Cl}_{2}$. 


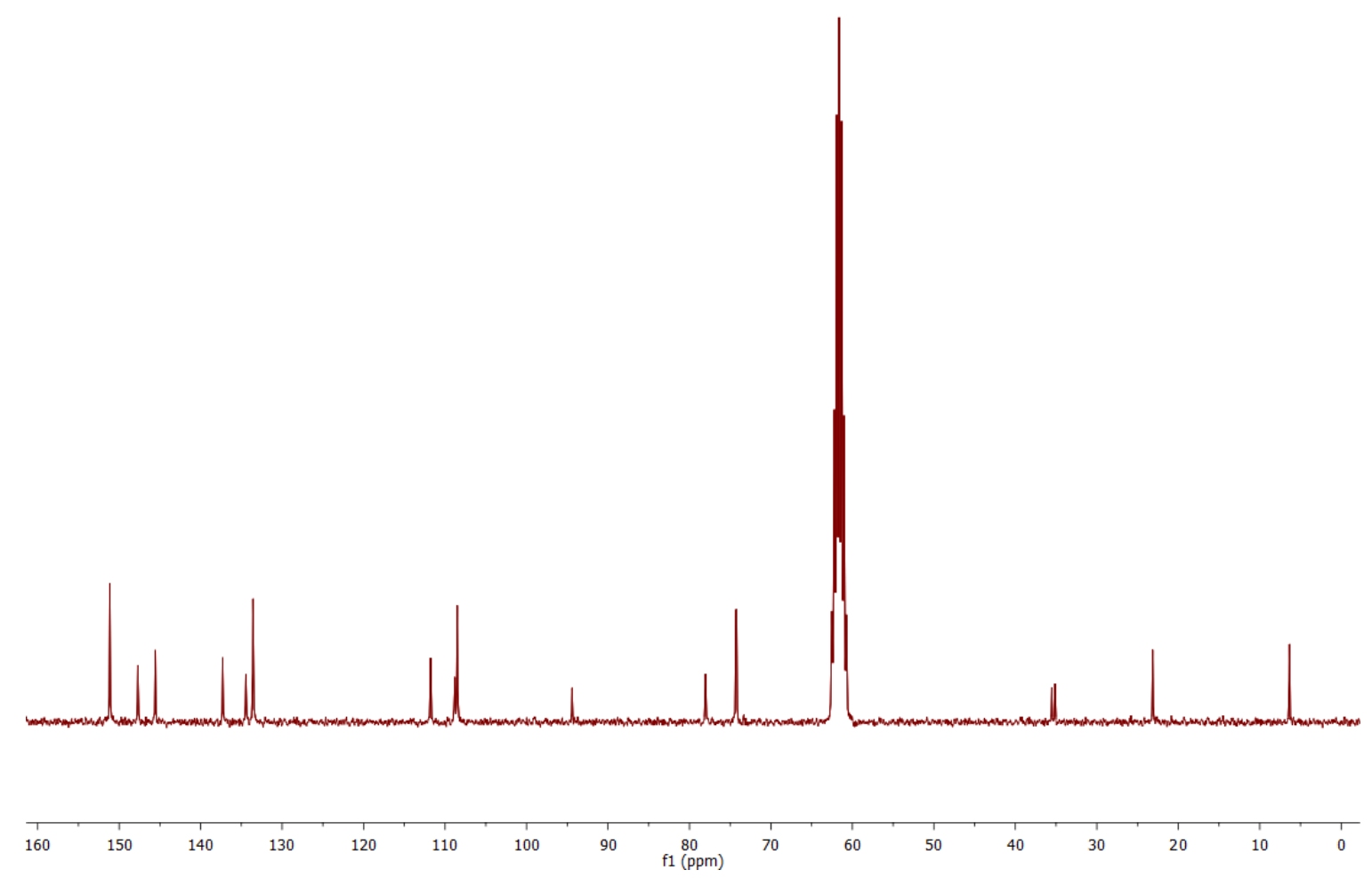

Figure 2.6. ${ }^{13} \mathrm{C}$ NMR spectrum of $\left[\kappa^{3}-\mathrm{C}(\mathrm{pz})_{4}\right] \mathrm{RuCl}_{2}\left[\mathrm{P}\left(\mathrm{OCH}_{2}\right)_{3} \mathrm{CEt}\right](3)$ in $\mathrm{CD}_{3} \mathrm{NO}_{2}$.

Complex 3 provides a possible direct route to the target precursor $\left[\kappa^{3}-\right.$ $\left.\mathrm{C}(\mathrm{pz})_{4}\right] \mathrm{Ru}(\mathrm{X})(\mathrm{Cl})\left[\mathrm{P}\left(\mathrm{OCH}_{2}\right)_{3} \mathrm{CEt}\right](\mathrm{X}=\mathrm{NHPh}, \mathrm{OPh}, \mathrm{OMe})$ via $\mathrm{X}^{-} / \mathrm{Cl}^{-}$metathesis. Initial attempts to prepare the heteroatomic complexes from 3 were by direct reaction with MX $(\mathrm{M}=\mathrm{Li}, \mathrm{X}=\mathrm{NHPh} ; \mathrm{M}=\mathrm{Na}, \mathrm{X}=\mathrm{OPh}, \mathrm{OMe})(\mathrm{Scheme} 2.5)$. Different solvents $\left(\mathrm{CH}_{2} \mathrm{Cl}_{2}\right.$, tetrahydrofuran, pyridine, dioxane, 1,2-dichlorobenzene) were tried. Reaction temperatures ranged from room temperature to $100{ }^{\circ} \mathrm{C}$. Multiple intractable products were observed. Isolation and characterization of products were unsuccessful. 


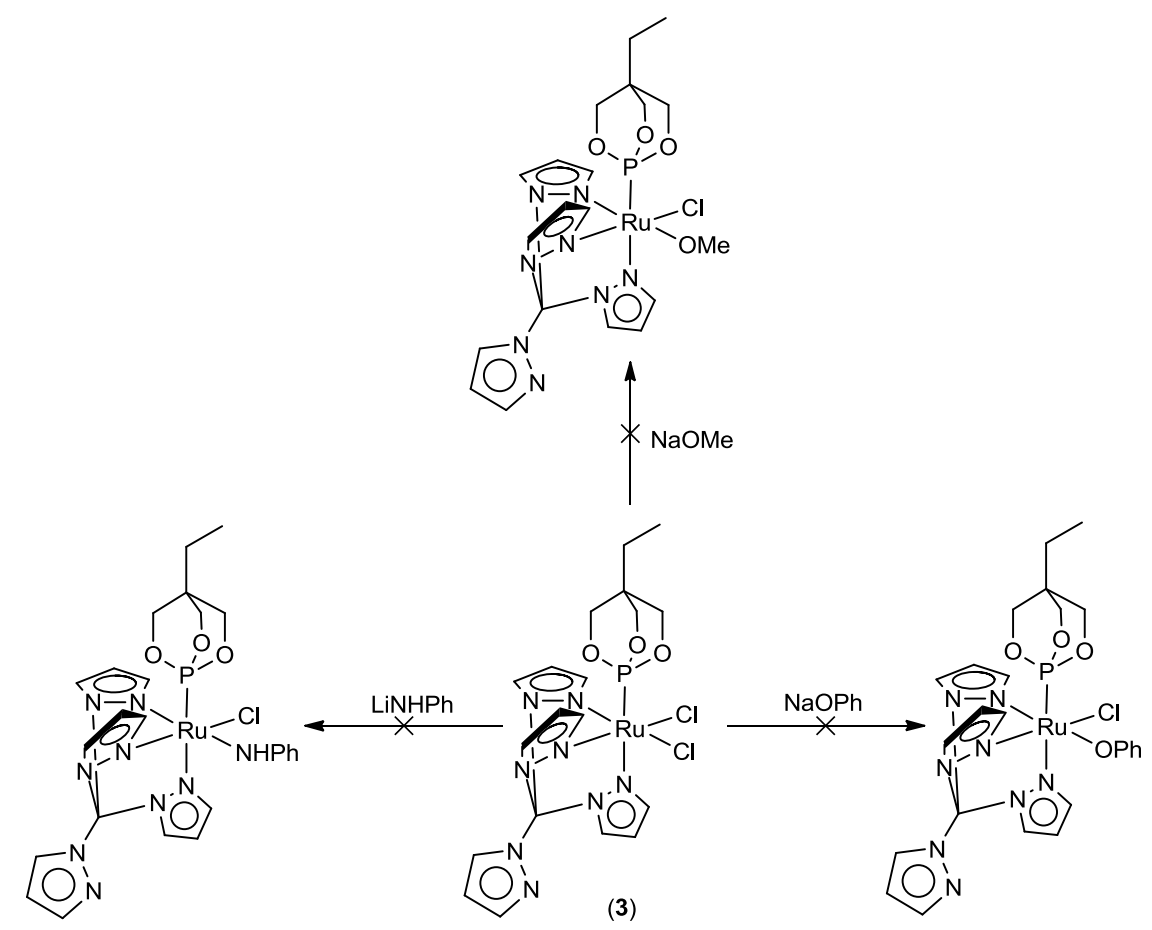

Scheme 2.5. Attempts to synthesize complexes possessing $M-X$ bonds from 3 .

An alternate protocol for the synthesis of $\mathrm{Ru}-\mathrm{X}$ complexes was by reaction of complex 3 with aniline or methanol to form $\left\{\left[\kappa^{3}-\mathrm{C}(\mathrm{pz})_{4}\right] \mathrm{Ru}(\mathrm{XH})(\mathrm{Cl})\left[\mathrm{P}\left(\mathrm{OCH}_{2}\right)_{3} \mathrm{CEt}\right]\right\} \mathrm{Cl}(\mathrm{X}=$ $\mathrm{NHPh}$ or $\mathrm{OMe}$ ) (Scheme 2.6). It was speculated that deprotonation of $\left\{\mathrm{C}(\mathrm{pz})_{4} \mathrm{Ru}(\mathrm{XH})(\mathrm{Cl})\left[\mathrm{P}\left(\mathrm{OCH}_{2}\right)_{3} \mathrm{CEt}\right]\right\}(\mathrm{Cl})$ would result in the desired complexes. Reactions were attempted in pure methanol or pure aniline at temperatures up to $90{ }^{\circ} \mathrm{C}$. Reactions were also set up in different solvents $\left(\mathrm{CH}_{2} \mathrm{Cl}_{2}\right.$, nitrobenzene, chloroform). All of the reactions yielded multiple products, of which the identities remain unclear. None of the multiple products could be cleanly isolated. 


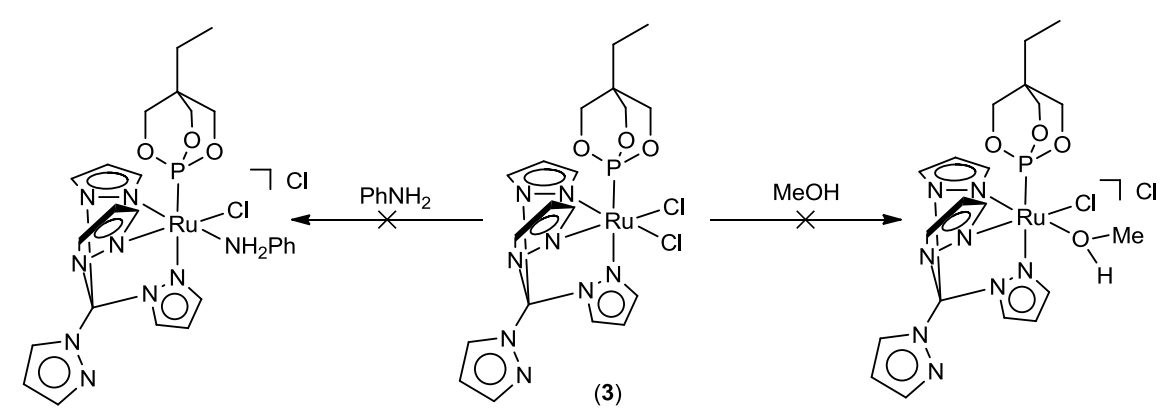

Scheme 2.6. Attempts to synthesize $\mathrm{Ru}$-aniline and $\mathrm{Ru}-$ methanol complexes from 3 .

Based on previous studies from our group, a feasible method to reach the $\mathrm{M}-\mathrm{X}$ complexes from bis-halide system is replacing the halide atom with a more labile triflate reagent to form a M-OTf bond and then replacing the labile triflate ligand by subsequent reaction with a nucleophile to form the $\mathrm{M}-\mathrm{X}$ bond. Silver triflate was employed as a triflate reagent and aniline or methanol served as nucleophile (Scheme 2.7). Reactions were tried in pure methanol or pure aniline at temperatures up to $90{ }^{\circ} \mathrm{C}$. Reactions were also set up in different solvents $\left(\mathrm{CH}_{2} \mathrm{Cl}_{2}\right.$, nitrobenzene, chloroform). However, none of the reactions proceeded cleanly. All of these reactions produced multiple products, of which isolation of clean product was unsuccessful.

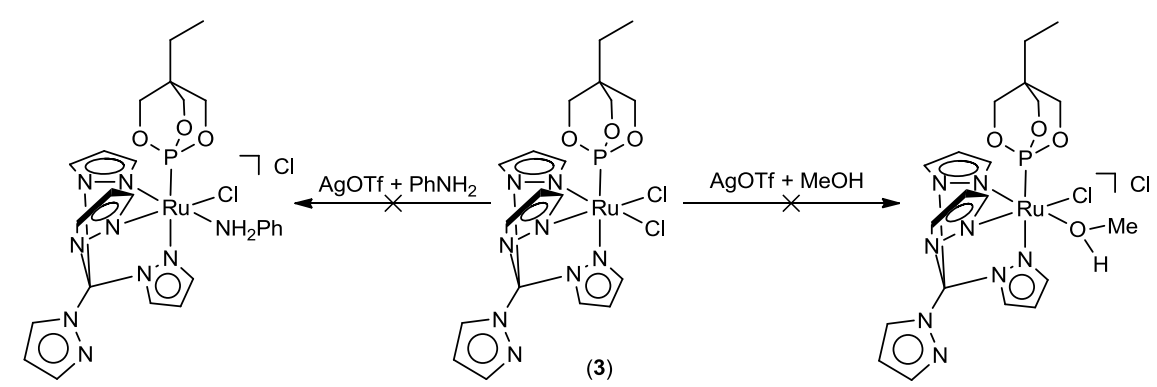

Scheme 2.7. Attempts to synthesize complexes bearing aniline or methanol ligand from complex 3 by using labile triflate ligand. 
Next, the non-oxidizing TIOTf was employed. Stirring a mixture of $\mathbf{3}$ and TlOTf in $\mathrm{CH}_{2} \mathrm{Cl}_{2}$ at room temperature for 30 minutes followed by filtration and solvent removal results in a yellow-green tacky residue. Refluxing the residue in tetrahydrofuran gives rise to a yellow precipitate which is identified as a dimeric compound with the formula of $\left\{\left[\kappa^{3}-\mathrm{C}(\mathrm{pz})_{4}\right] \mathrm{Ru}(\mu-\mathrm{Cl})\left[\mathrm{P}\left(\mathrm{OCH}_{2}\right)_{3} \mathrm{CEt}\right]\right\}_{2}\{\mathrm{OTf}\}_{2}$ (4) (Scheme 2.8). The ${ }^{1} \mathrm{H}$ NMR spectral data are consistent with the formation of a new complex (Figure 2.7). The ${ }^{1} \mathrm{H}$ NMR spectrum indicates nine resonances in the downfield $\mathrm{C}(\mathrm{pz})_{4}$ region, implying $\mathrm{C}_{\mathrm{s}}$ molecular symmetry (Figure 2.8). The singlet for the phosphite ligand at $128.6 \mathrm{ppm}$ in ${ }^{31} \mathrm{P}$ NMR spectrum (Figure 2.9) is also consistent with the formation of a new complex. The singlet at $-77.5 \mathrm{ppm}$ in ${ }^{19} \mathrm{~F}$ NMR spectrum in $\mathrm{CD}_{2} \mathrm{Cl}_{2}$ indicates the existence of uncoordinated OTf serving as counterion (Figure 2.10). The ${ }^{13} \mathrm{C}$ NMR spectrum indicates the isolation of clean product (Figure 2.11).

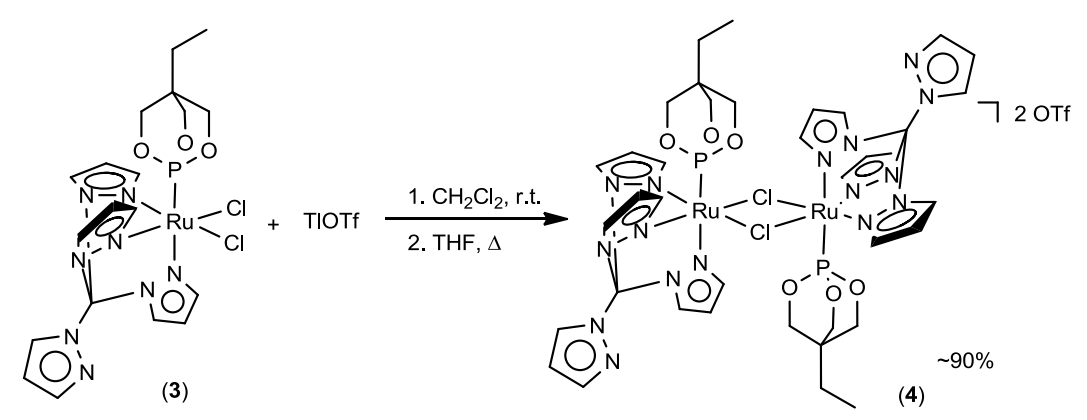

Scheme 2.8. Synthesis of $\left\{\left[\kappa^{3}-\mathrm{C}(\mathrm{pz})_{4}\right] \mathrm{Ru}(\mu-\mathrm{Cl})\left[\mathrm{P}\left(\mathrm{OCH}_{2}\right)_{3} \mathrm{CEt}\right]\right\}_{2}\{\mathrm{OTf}\}_{2}(\mathbf{4})$. 


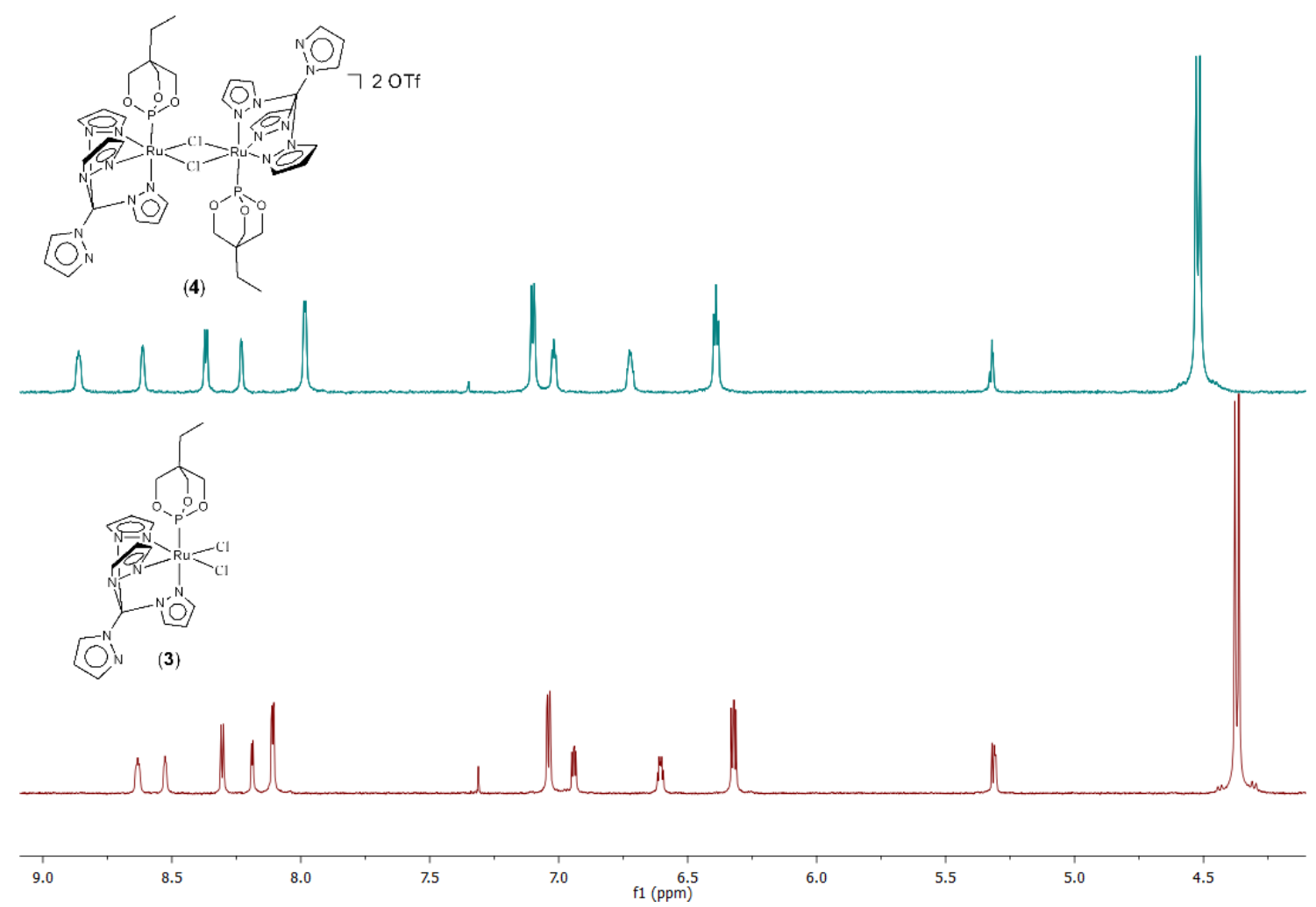

Figure 2.7. Comparison of ${ }^{1} \mathrm{H}$ NMR spectra of $\mathbf{3}$ (bottom) and $\mathbf{4}$ (top) in $\mathrm{CD}_{2} \mathrm{Cl}_{2}$.

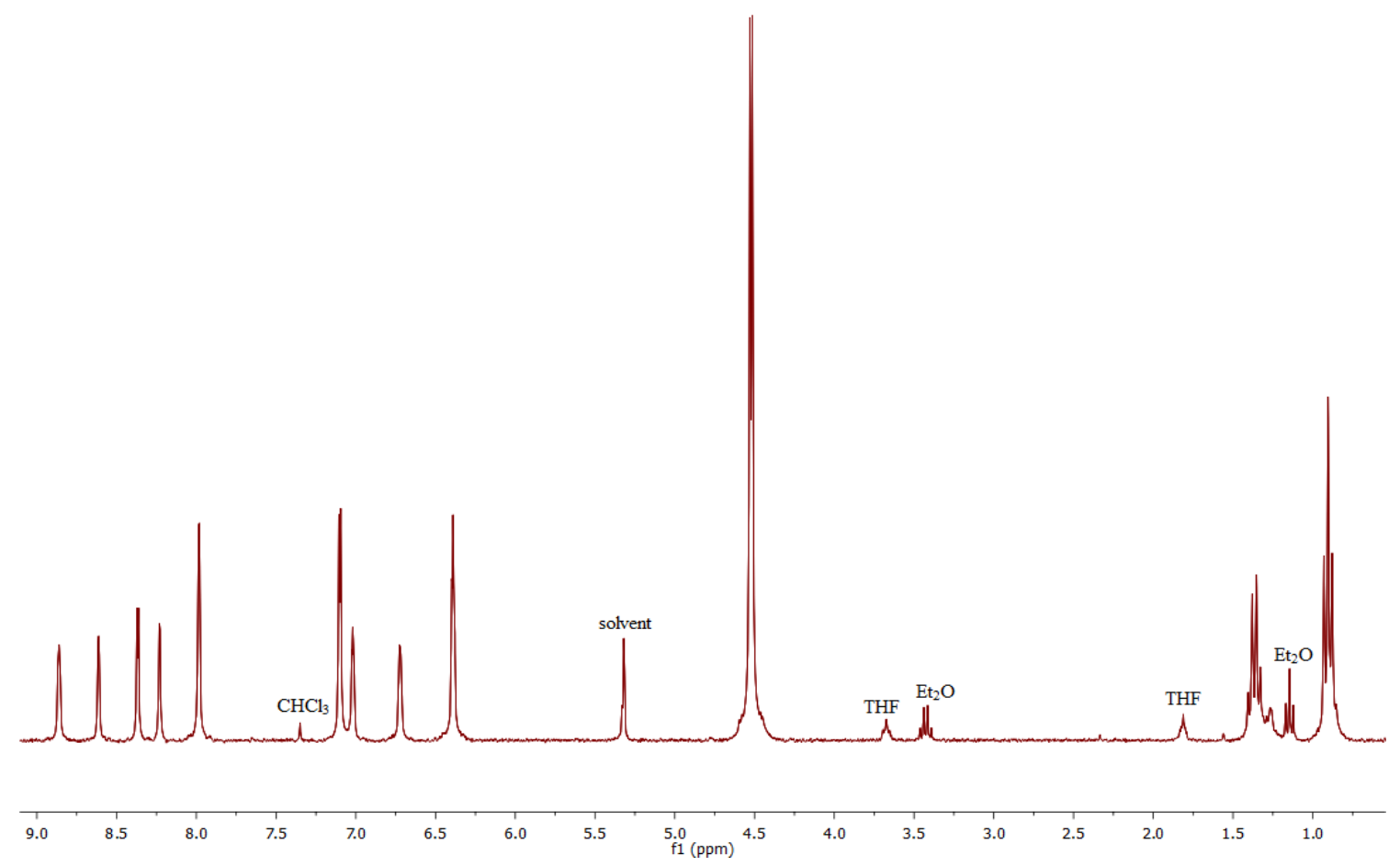

Figure 2.8. ${ }^{1} \mathrm{H} N M R$ spectrum of $\left\{\left[\kappa^{3}-\mathrm{C}(\mathrm{pz})_{4}\right] \mathrm{Ru}(\mu-\mathrm{Cl})\left[\mathrm{P}\left(\mathrm{OCH}_{2}\right)_{3} \mathrm{CEt}\right]\right\}_{2}\{\mathrm{OTf}\}_{2}(4)$ in $\mathrm{CD}_{2} \mathrm{Cl}_{2}$. 


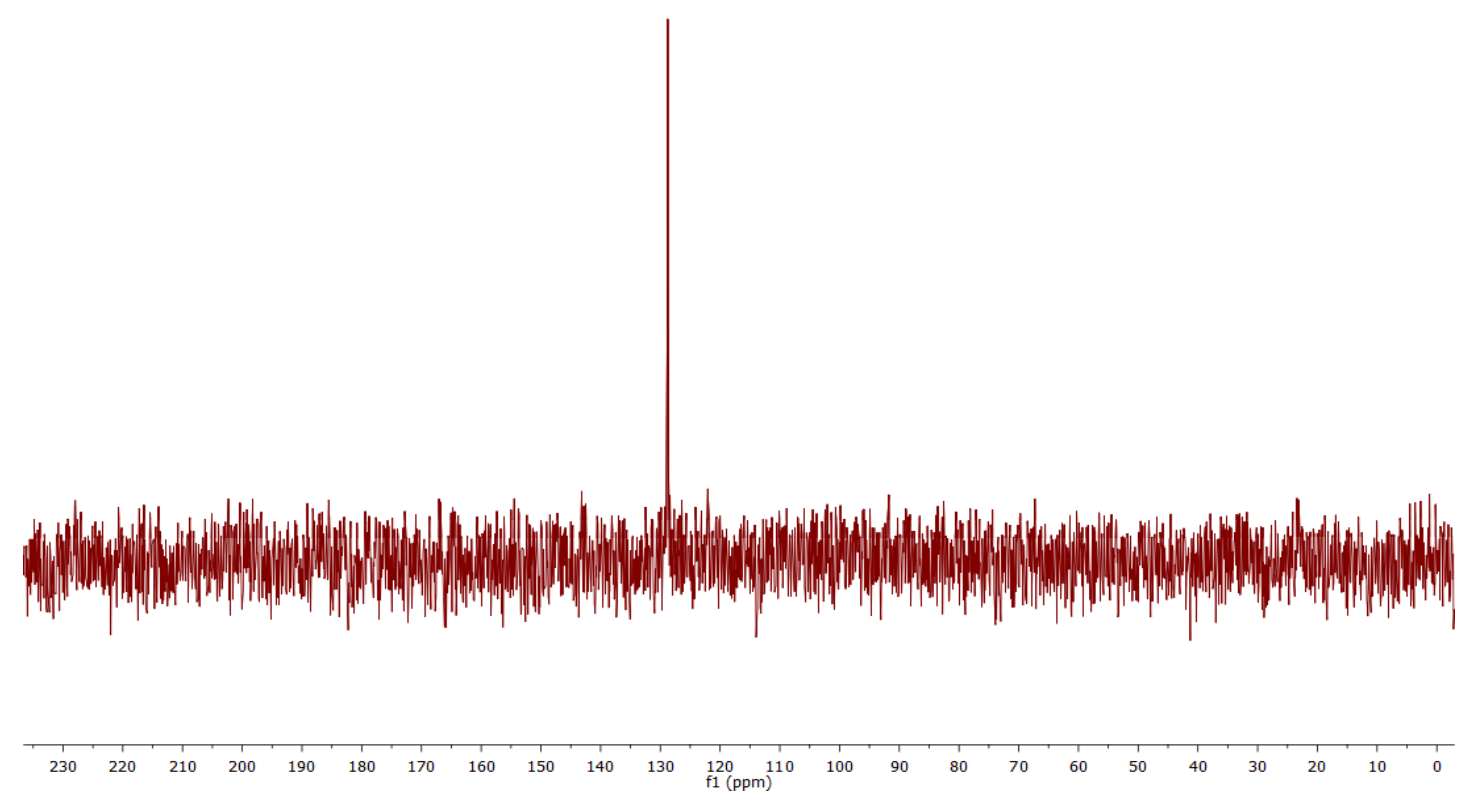

Figure 2.9. ${ }^{31} \mathrm{P} N M R$ spectrum of $\left\{\left[\kappa^{3}-\mathrm{C}(\mathrm{pz})_{4}\right] \mathrm{Ru}(\mu-\mathrm{Cl})\left[\mathrm{P}\left(\mathrm{OCH}_{2}\right)_{3} \mathrm{CEt}\right]\right\}_{2}\{\mathrm{OTf}\}_{2}(4)$ in $\mathrm{CD}_{2} \mathrm{Cl}_{2}$.

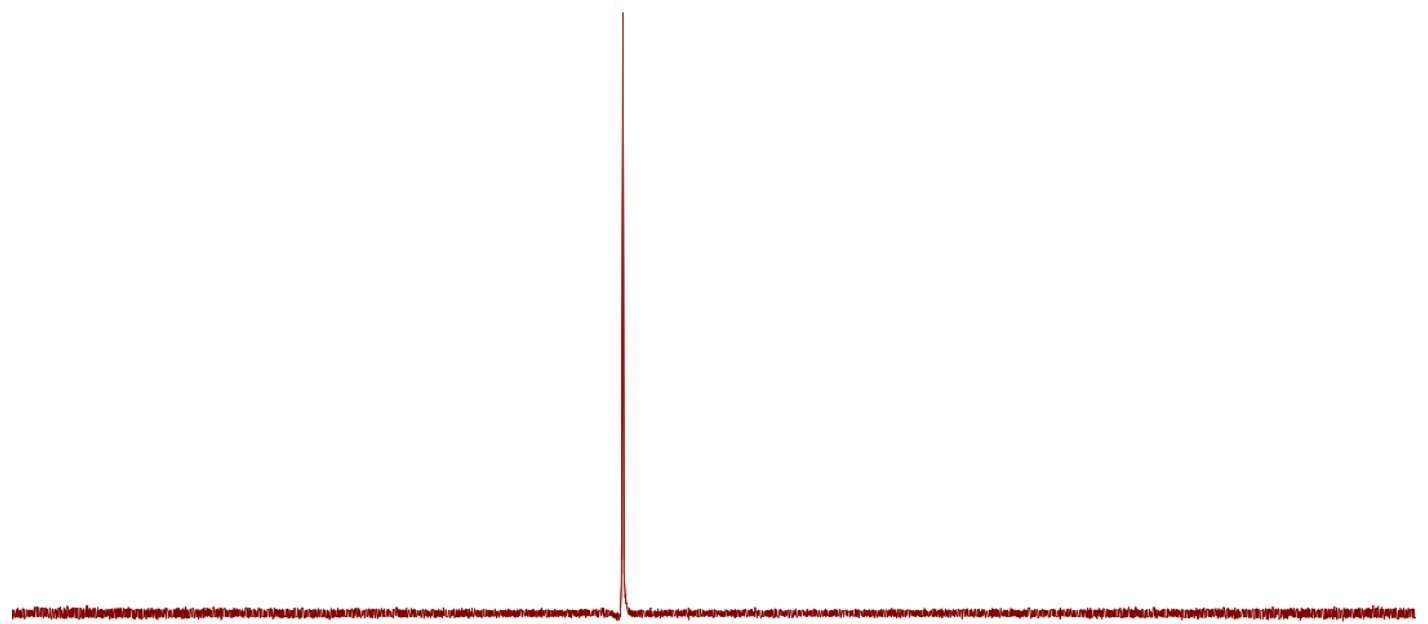

$\begin{array}{lllllllllllllllllllllllllllll}30 & 20 & 10 & 0 & -10 & -20 & -30 & -40 & -50 & -60 & -70 & -80 & -90 & -100 & -110 & -120 & -130 & -140 & -150 & -160 & -170 & -180 & -190 & -200 & -210 & -220 & -23\end{array}$

Figure 2.10. ${ }^{19} \mathrm{~F}$ NMR spectrum of $\left\{\left[\kappa^{3}-\mathrm{C}(\mathrm{pz})_{4}\right] \mathrm{Ru}(\mu-\mathrm{Cl})\left[\mathrm{P}\left(\mathrm{OCH}_{2}\right)_{3} \mathrm{CEt}\right]\right\}_{2}\{\mathrm{OTf}\}_{2}(\mathbf{4})$ in $\mathrm{CD}_{2} \mathrm{Cl}_{2}$. 


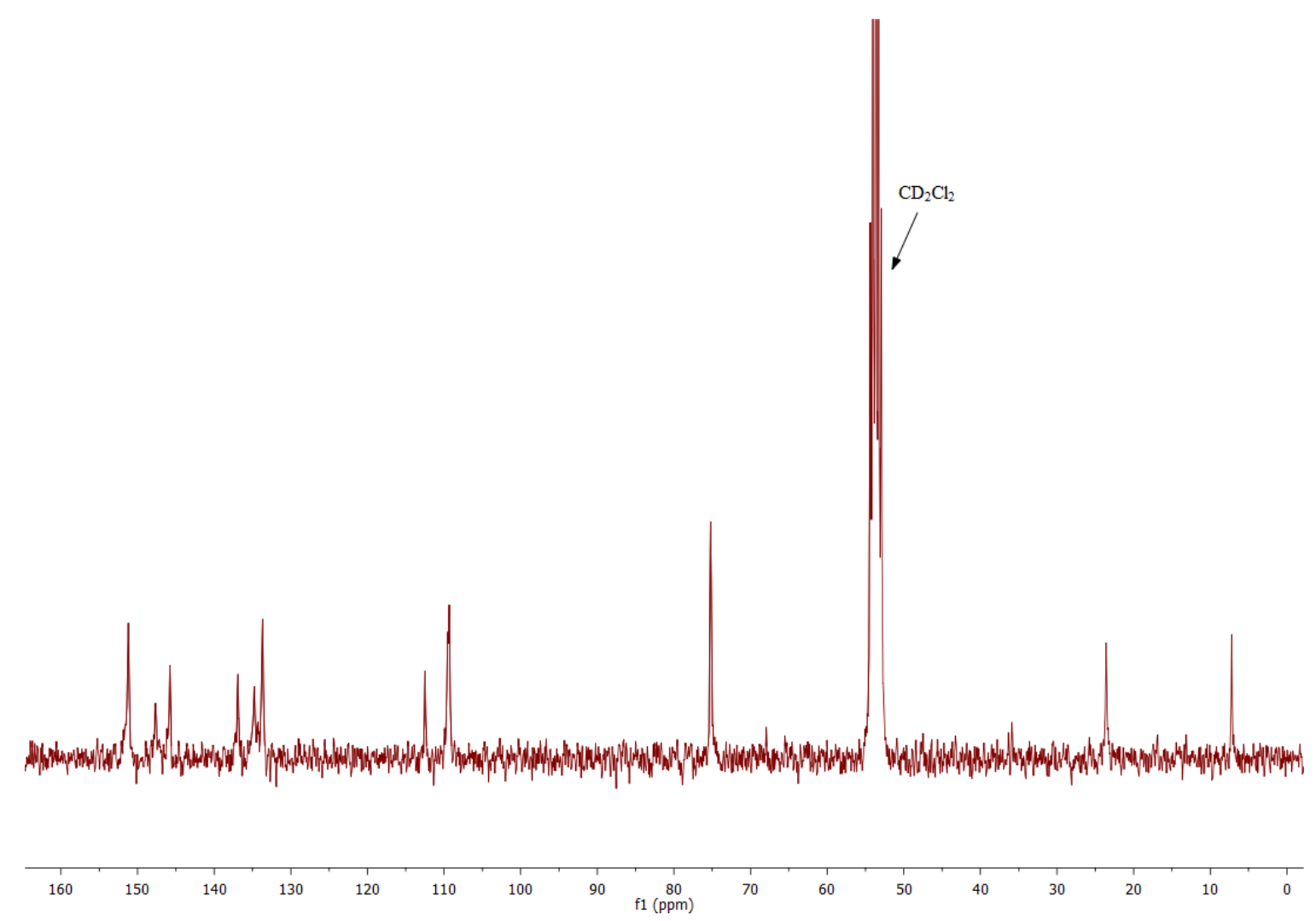

Figure 2.11. ${ }^{13} \mathrm{C}$ NMR spectrum of $\left\{\left[\kappa^{3}-\mathrm{C}(\mathrm{pz})_{4}\right] \mathrm{Ru}(\mu-\mathrm{Cl})\left[\mathrm{P}\left(\mathrm{OCH}_{2}\right)_{3} \mathrm{CEt}\right]\right\}_{2}\{\mathrm{OTf}\}_{2}(\mathbf{4})$ in $\mathrm{CD}_{2} \mathrm{Cl}_{2}$.

Complex 4 presents a potential synthetic pathway to the targeted metal-heteroatom system if it is in equilibrium with monomer (Scheme 2.9). Access to a monomer form 4 can be verified by adding trimethylphosphine to a $\mathrm{CH}_{2} \mathrm{Cl}_{2}$ solution of complex 4 . After the addition of trimethylphosphine, two doublets are observed in the ${ }^{31} \mathrm{P}$ NMR spectrum for the coordinated phosphite and phosphine ligands $\left({ }^{2} J_{\mathrm{PP}}=594 \mathrm{~Hz}\right)$ while free $\mathrm{PMe}_{3}$ resonates at $-60.9 \mathrm{ppm}(\mathrm{s})$ and the phosphite ligand of $\mathbf{4}$ resonates at $128.6 \mathrm{ppm}(\mathrm{s})$ (Figure 2.12). These doublets suggest that 4 likely exists in equilibrium with monomer, thus opening a synthetic route to the desired product. 


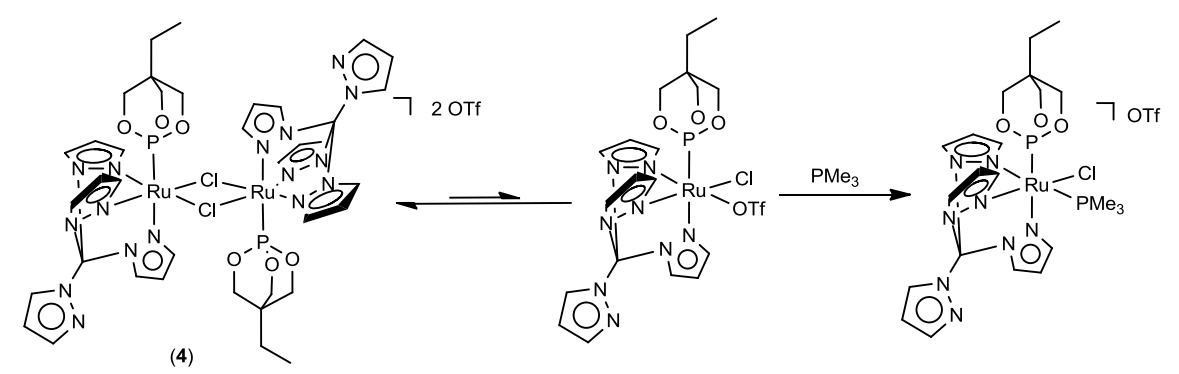

Scheme 2.9. Proposed dimer/monomer equilibrium in the solution of complex 4 and reaction with $\mathrm{PMe}_{3}$ that confirms access to monomer.
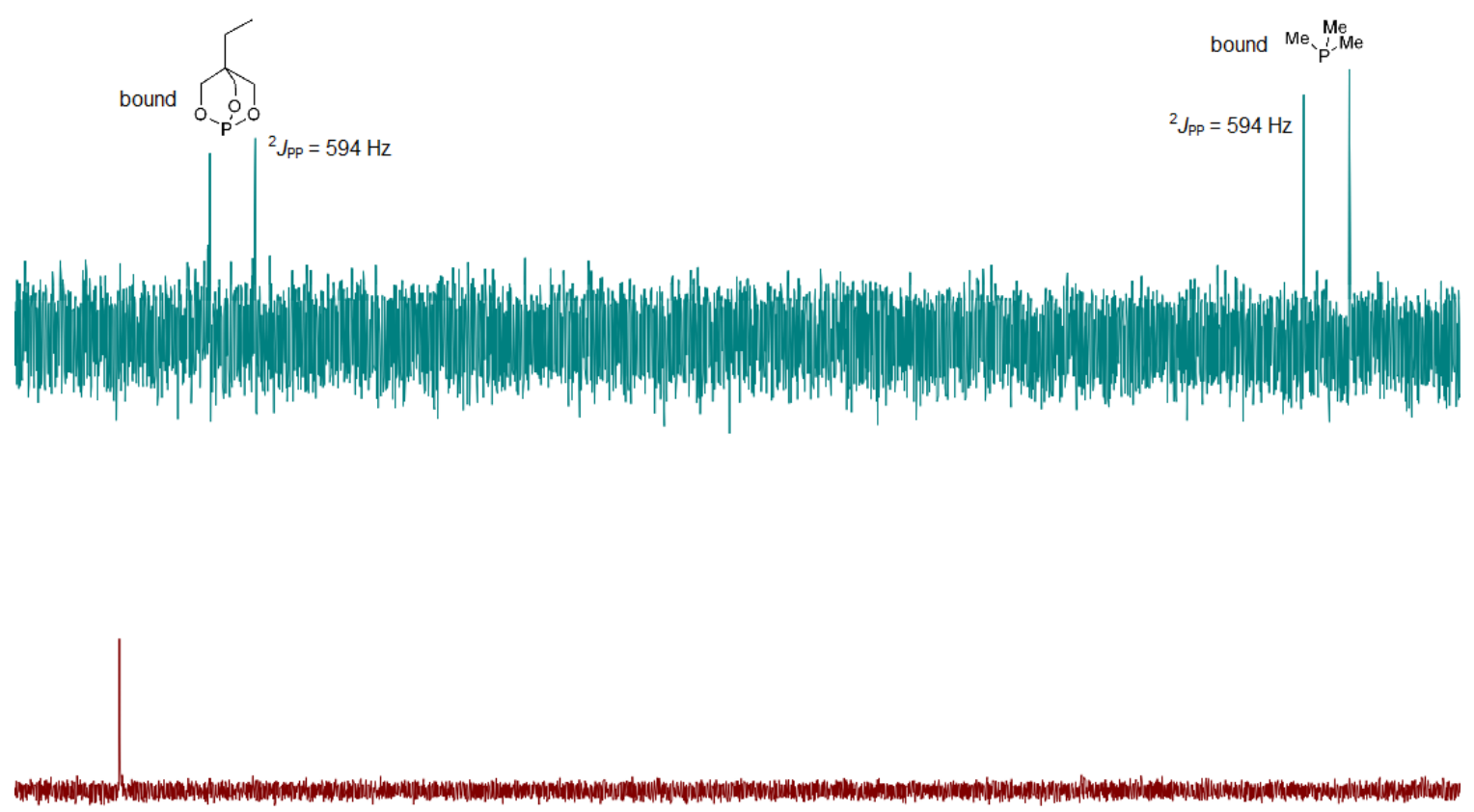

$\begin{array}{lllllllllllllllllllllllllllllllllllllll}135 & 125 & 115 & 105 & 95 & 90 & 85 & 80 & 75 & 70 & 65 & 60 & 55 & 50 & 45 & 40 & 35 & 30 & 25 & 20 & 15 & 10 & 5 & 0 & -5 & -10 & -1\end{array}$

Figure 2.12. ${ }^{31} \mathrm{P}$ NMR spectra of dimer 4 in $\mathrm{CD}_{2} \mathrm{Cl}_{2}$ : before addition of $\mathrm{PMe}_{3}$ (bottom) and after addition of $\mathrm{PMe}_{3}$ (top).

\subsubsection{Synthesis and Reactivity of Ru(II)-aniline complexes}

The reaction of dimer 4 with ten equivalents of aniline in THF at $90{ }^{\circ} \mathrm{C}$ for three days produces $\left\{\left[\kappa^{3}-\mathrm{C}(\mathrm{pz})_{4}\right] \mathrm{Ru}\left[\mathrm{P}\left(\mathrm{OCH}_{2}\right)_{3} \mathrm{CEt}\right](\mathrm{Cl})\left(\mathrm{NH}_{2} \mathrm{Ph}\right)\right\}\{\mathrm{OTf}\}$ (5) in $\sim 70 \%$ isolated yield 
(Scheme 2.10). $\left[\kappa^{3}-\mathrm{C}(\mathrm{pz})_{4}\right]-\mathrm{Ru}$ complexes with $\mathrm{C}_{\mathrm{s}}$ molecular symmetry give nine resonances for the $\mathrm{C}(\mathrm{pz})_{4}$ ligand in ${ }^{1} \mathrm{H}$ NMR spectra. For asymmetric complexes, twelve resonances are observed for the $\mathrm{C}(\mathrm{pz})_{4}$ ligand. The ${ }^{1} \mathrm{H}$ NMR spectrum of complex 5 contains twelve resonances in the downfield $\mathrm{C}(\mathrm{pz})_{4}$ region, indicating an asymmetric complex (Figure 2.13). The doublets (4.77 ppm and $5.72 \mathrm{ppm},{ }^{2} J_{\mathrm{HH}}=12 \mathrm{~Hz}$ ) for two protons of aniline and multiplets for phenyl ring of aniline at 6.7-7.2 ppm demonstrate coordination of aniline. In ${ }^{1} \mathrm{H}$ gCOSY spectrum of complex $\mathbf{5}$, the identities of doublets for two protons on nitrogen of aniline are clearly confirmed by the two cross peaks correlated to each other (Figure 2.14). The doublets result from a diastereotopic $\mathrm{NH}_{2}$ group. The singlet for triflate anion at $-79.5 \mathrm{ppm}$, where free TlOTf resonate, in ${ }^{19} \mathrm{~F}$ NMR spectrum confirms that triflate remains uncoordinated (Figure 2.15). The isolation of complex 5 is also indicated by ${ }^{31} \mathrm{P}$ NMR and ${ }^{13} \mathrm{C}$ NMR spectra (Figure 2.16 and Figure 2.17 , respectively).

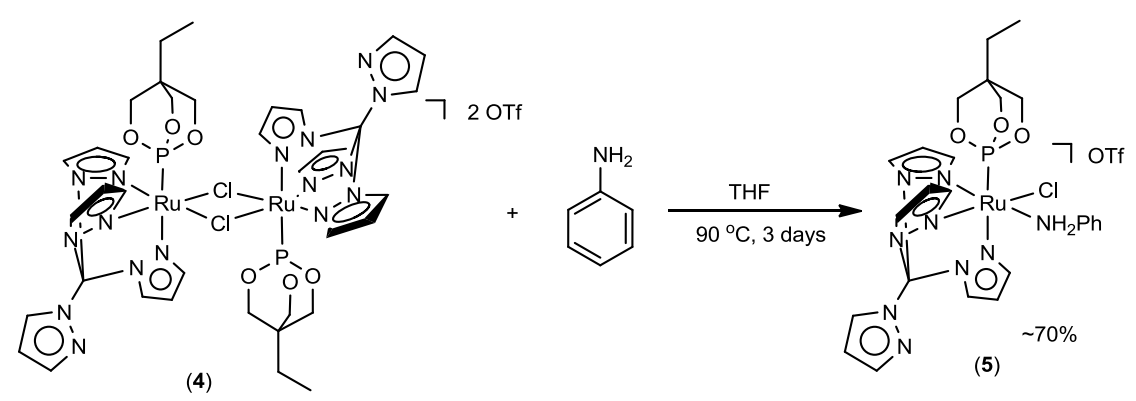

Scheme 2.10. Synthesis of $\left\{\left[\kappa^{3}-\mathrm{C}(\mathrm{pz})_{4}\right] \mathrm{Ru}\left[\mathrm{P}\left(\mathrm{OCH}_{2}\right)_{3} \mathrm{CEt}\right](\mathrm{Cl})\left(\mathrm{NH}_{2} \mathrm{Ph}\right)\right\}\{\mathrm{OTf}\}(\mathbf{5})$. 

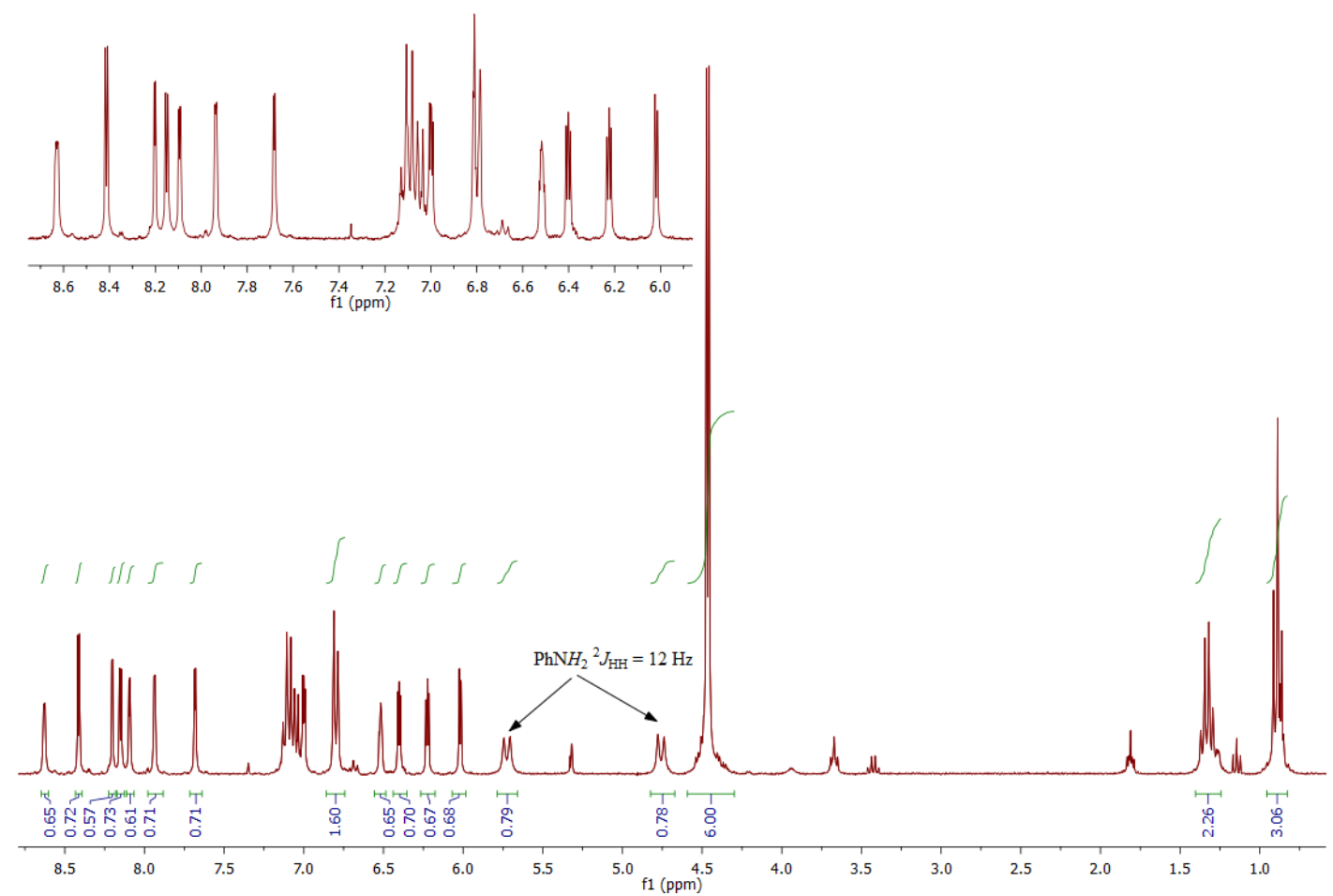

Figure 2.13. ${ }^{1} \mathrm{H}$ NMR spectrum of $\left\{\left[\kappa^{3}-\mathrm{C}(\mathrm{pz})_{4}\right] \mathrm{Ru}\left[\mathrm{P}\left(\mathrm{OCH}_{2}\right)_{3} \mathrm{CEt}\right](\mathrm{Cl})\left(\mathrm{NH}_{2} \mathrm{Ph}\right)\right\}\{\mathrm{OTf}\}$ (5) in $\mathrm{CD}_{2} \mathrm{Cl}_{2}$.

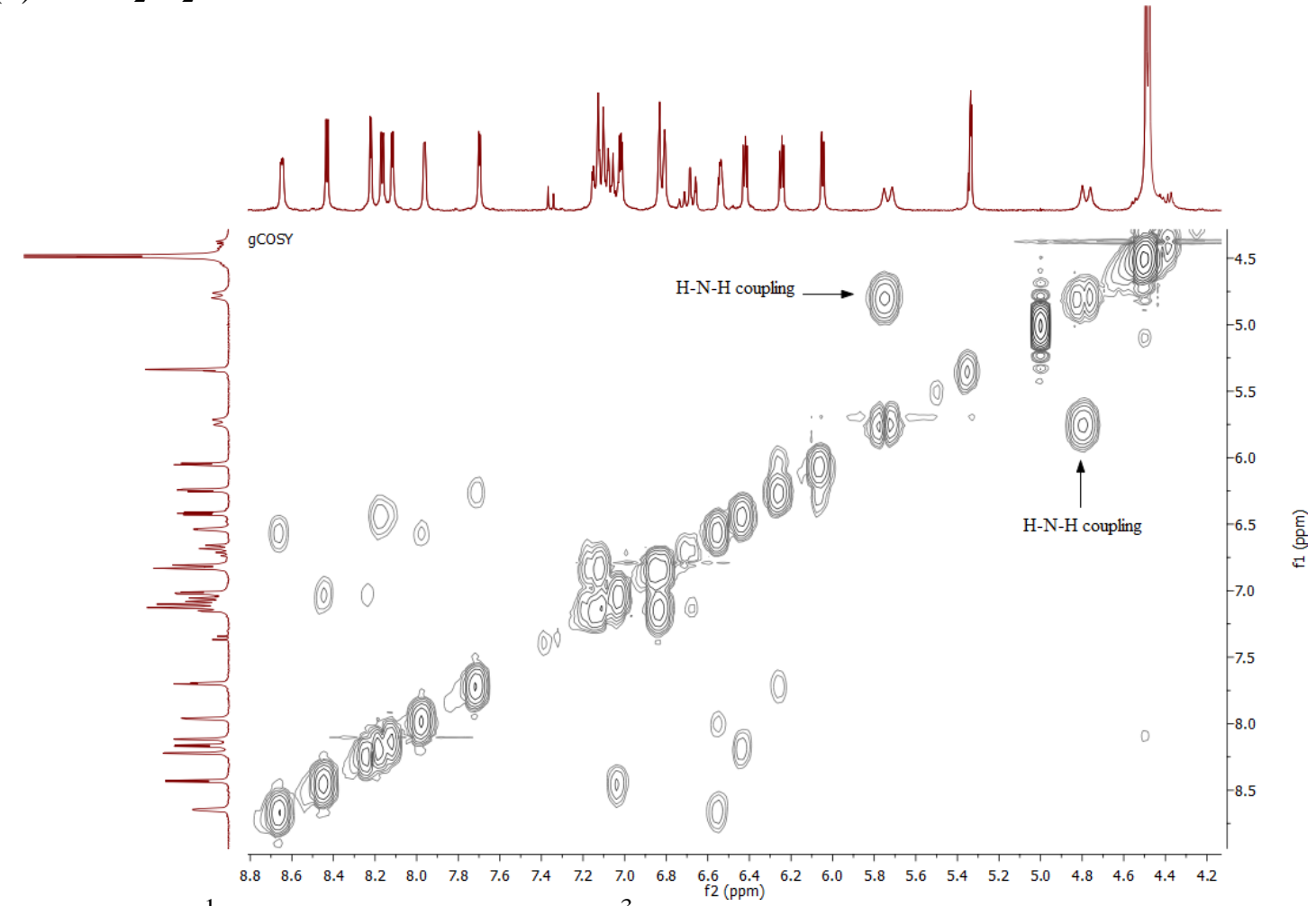

Figure 2.14. ${ }^{1} \mathrm{H}$ gCOSY spectrum of $\left\{\left[\kappa^{3}-\mathrm{C}(\mathrm{pz})_{4}\right] \mathrm{Ru}\left[\mathrm{P}\left(\mathrm{OCH}_{2}\right)_{3} \mathrm{CEt}\right](\mathrm{Cl})\left(\mathrm{NH}_{2} \mathrm{Ph}\right)\right\}\{\mathrm{OTf}\}$ (5) in $\mathrm{CD}_{2} \mathrm{Cl}_{2}$. 

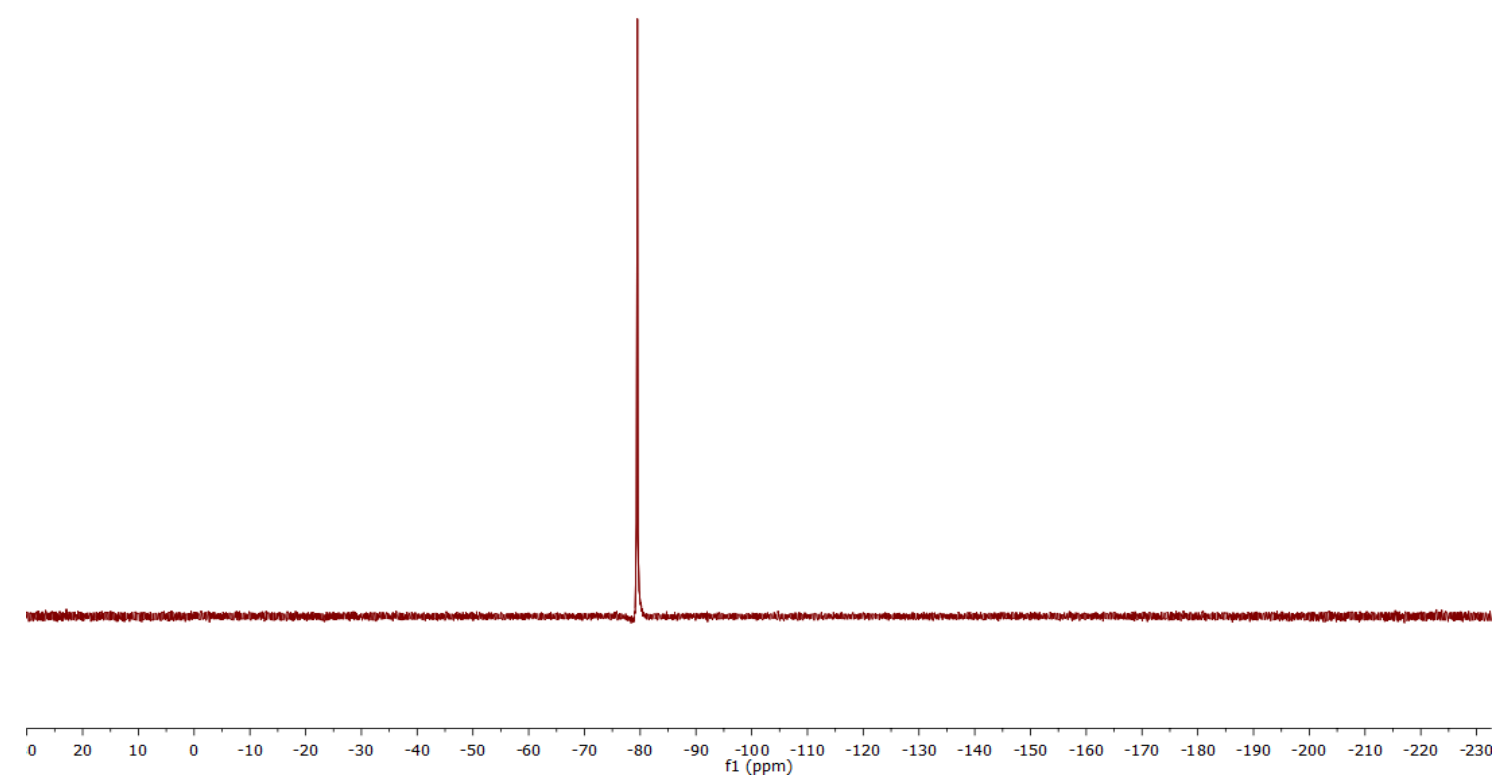

Figure 2.15. ${ }^{19} \mathrm{~F}$ NMR spectrum of $\left\{\left[\kappa^{3}-\mathrm{C}(\mathrm{pz})_{4}\right] \mathrm{Ru}\left[\mathrm{P}\left(\mathrm{OCH}_{2}\right)_{3} \mathrm{CEt}\right](\mathrm{Cl})\left(\mathrm{NH}_{2} \mathrm{Ph}\right)\right\}\{\mathrm{OTf}\}$ (5) in $\mathrm{CD}_{2} \mathrm{Cl}_{2}$.

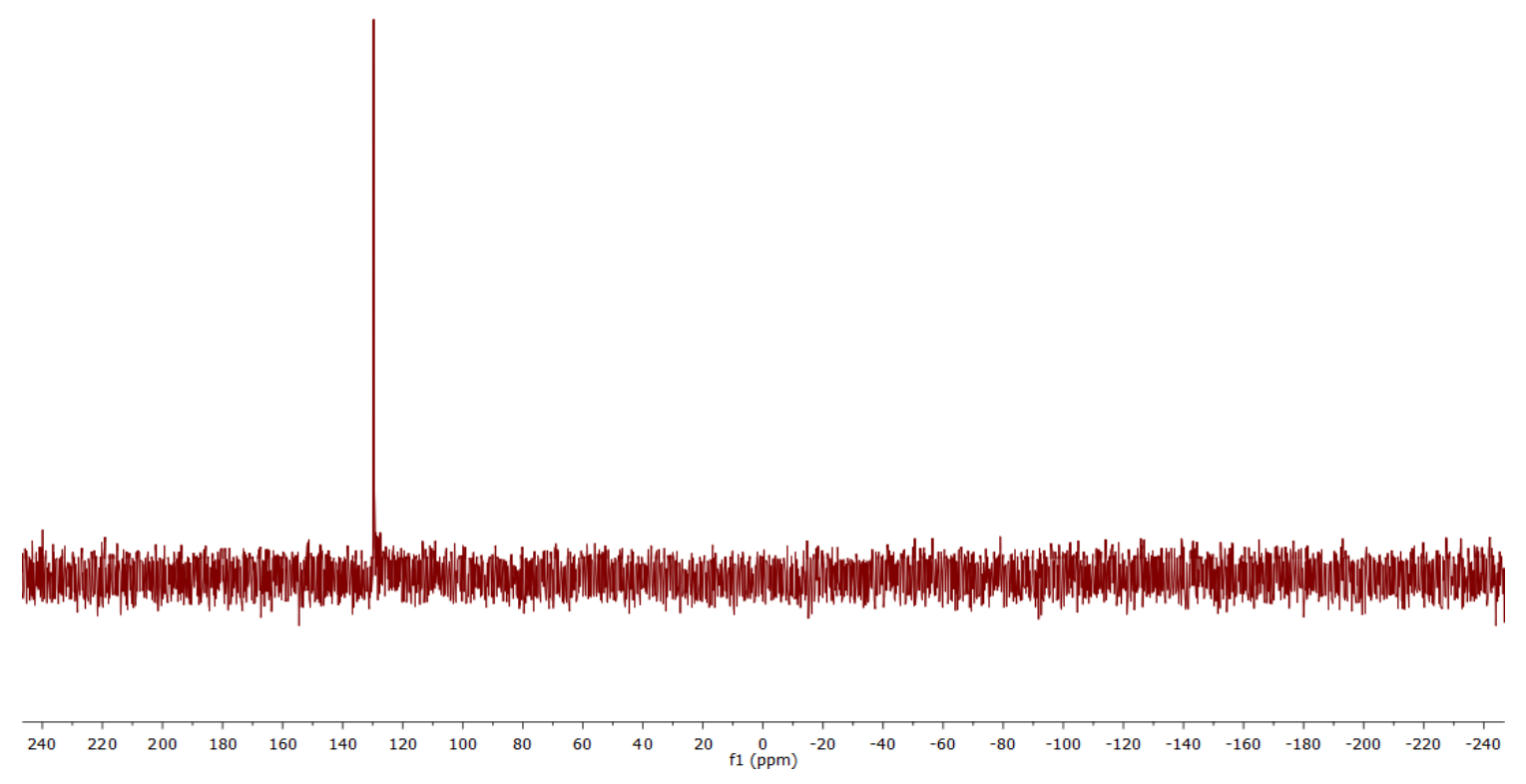

Figure 2.16. ${ }^{31} \mathrm{P}$ NMR spectrum of $\left\{\left[\kappa^{3}-\mathrm{C}(\mathrm{pz})_{4}\right] \mathrm{Ru}\left[\mathrm{P}\left(\mathrm{OCH}_{2}\right)_{3} \mathrm{CEt}\right](\mathrm{Cl})\left(\mathrm{NH}_{2} \mathrm{Ph}\right)\right\}\{\mathrm{OTf}\}$ (5) in $\mathrm{CD}_{2} \mathrm{Cl}_{2}$. 

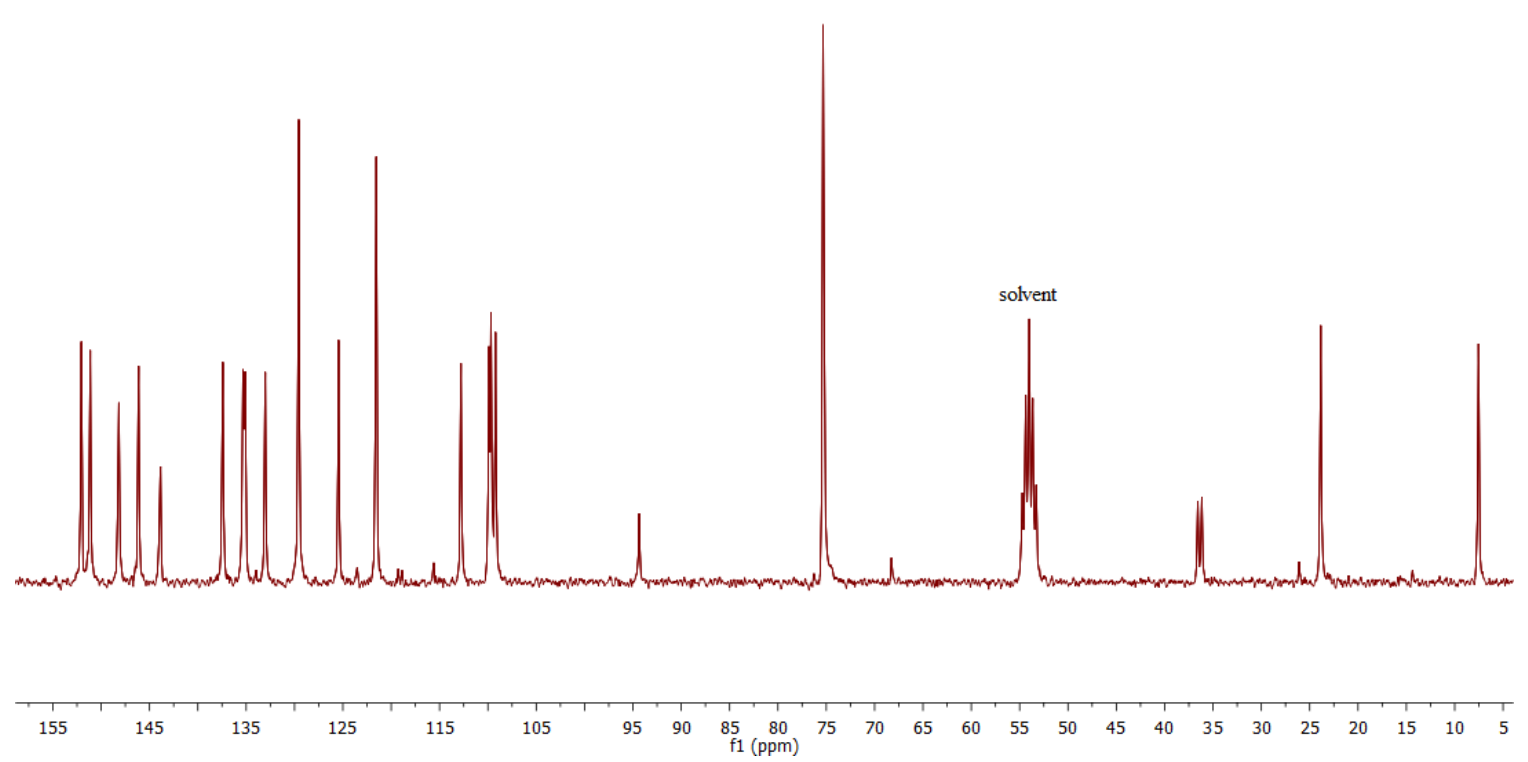

Figure 2.17. ${ }^{13} \mathrm{C}$ NMR spectrum of $\left\{\left[\kappa^{3}-\mathrm{C}(\mathrm{pz})_{4}\right] \mathrm{Ru}\left[\mathrm{P}\left(\mathrm{OCH}_{2}\right)_{3} \mathrm{CEt}\right](\mathrm{Cl})\left(\mathrm{NH}_{2} \mathrm{Ph}\right)\right\}\{\mathrm{OTf}\}$ (5) in $\mathrm{CD}_{2} \mathrm{Cl}_{2}$.

An isotopic labeling experiment convincingly demonstrates that aniline is coordinated to the metal center in complex $\mathbf{5}$. The ${ }^{15} \mathrm{~N}$-labeled complex $\mathbf{5}\left({ }^{15} \mathrm{~N}-\mathbf{5}\right)$ is synthesized by the steps mentioned above except for the use of ${ }^{15} \mathrm{~N}$-labeled aniline (Scheme 2.11). By introducing ${ }^{15} \mathrm{~N}$, the aniline protons are coupled not only to each other but also to the nitrogen $\left({ }^{1} J_{\mathrm{NH}}\right)$. The doublets for coordinated ${ }^{15} \mathrm{~N} H_{2} \mathrm{Ph}$ are split by the ${ }^{1} J$-coupling between ${ }^{1} \mathrm{H}$ and ${ }^{15} \mathrm{~N}$, exhibiting a doublet of doublets splitting pattern in the ${ }^{1} \mathrm{H}$ NMR spectrum. This is observed in the ${ }^{1} \mathrm{H}$ NMR spectrum of ${ }^{15} \mathrm{~N}-\mathbf{5}$, in which the doublet of doublets splitting pattern is clearly observed with larger ${ }^{1} J_{\mathrm{NH}}(73 \mathrm{~Hz})$ and smaller ${ }^{2} J_{\mathrm{HH}}$ $(12 \mathrm{~Hz})$ (Figure 2.18). These two sets of peaks are correlated to each other in the ${ }^{1} \mathrm{H}$ gCOSY spectrum of ${ }^{15} \mathrm{~N}-5$ due to ${ }^{2} J_{\mathrm{HH}}$-coupling (Figure 2.19). 

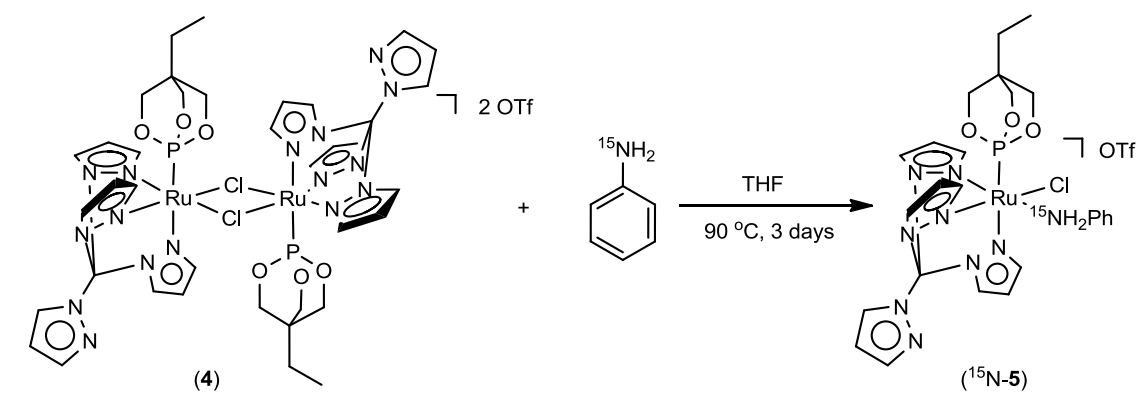

Scheme 2.11. Synthesis of ${ }^{15} \mathrm{~N}$-labeled complex $5\left({ }^{15} \mathrm{~N}-\mathbf{5}\right)$.
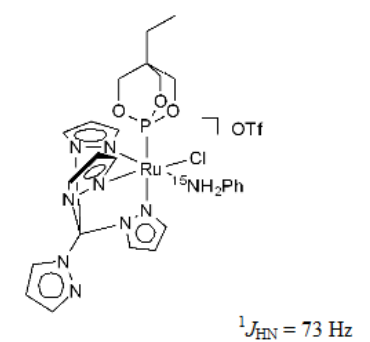

${ }^{2} \mathrm{JHH}_{\mathrm{HH}}=12 \mathrm{~Hz}$
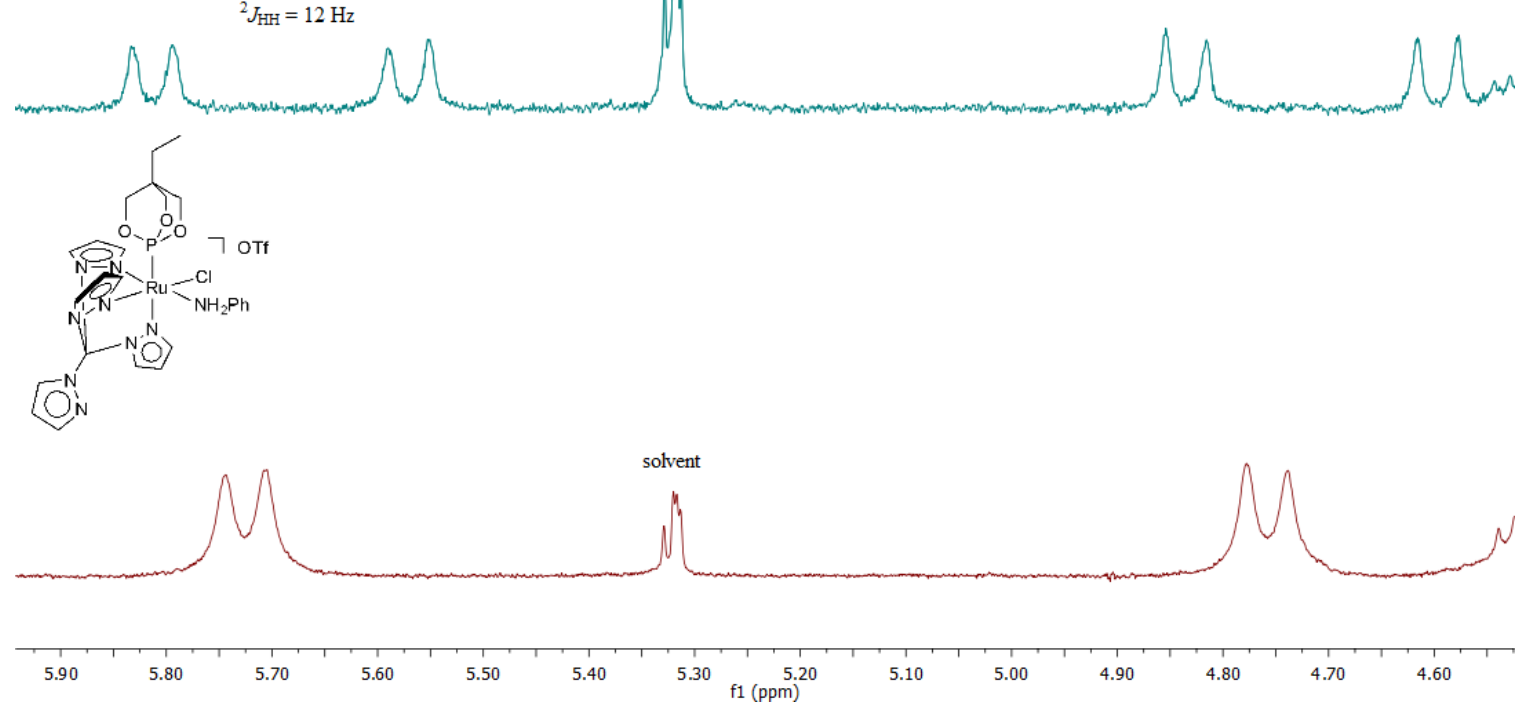

Figure 2.18. Different splitting patterns in ${ }^{1} \mathrm{H}$ NMR spectra of complex 5 in $\mathrm{CD}_{2} \mathrm{Cl}_{2}$ : before (bottom) and after (top) introducing ${ }^{15} \mathrm{NH}_{2} \mathrm{Ph}$. 


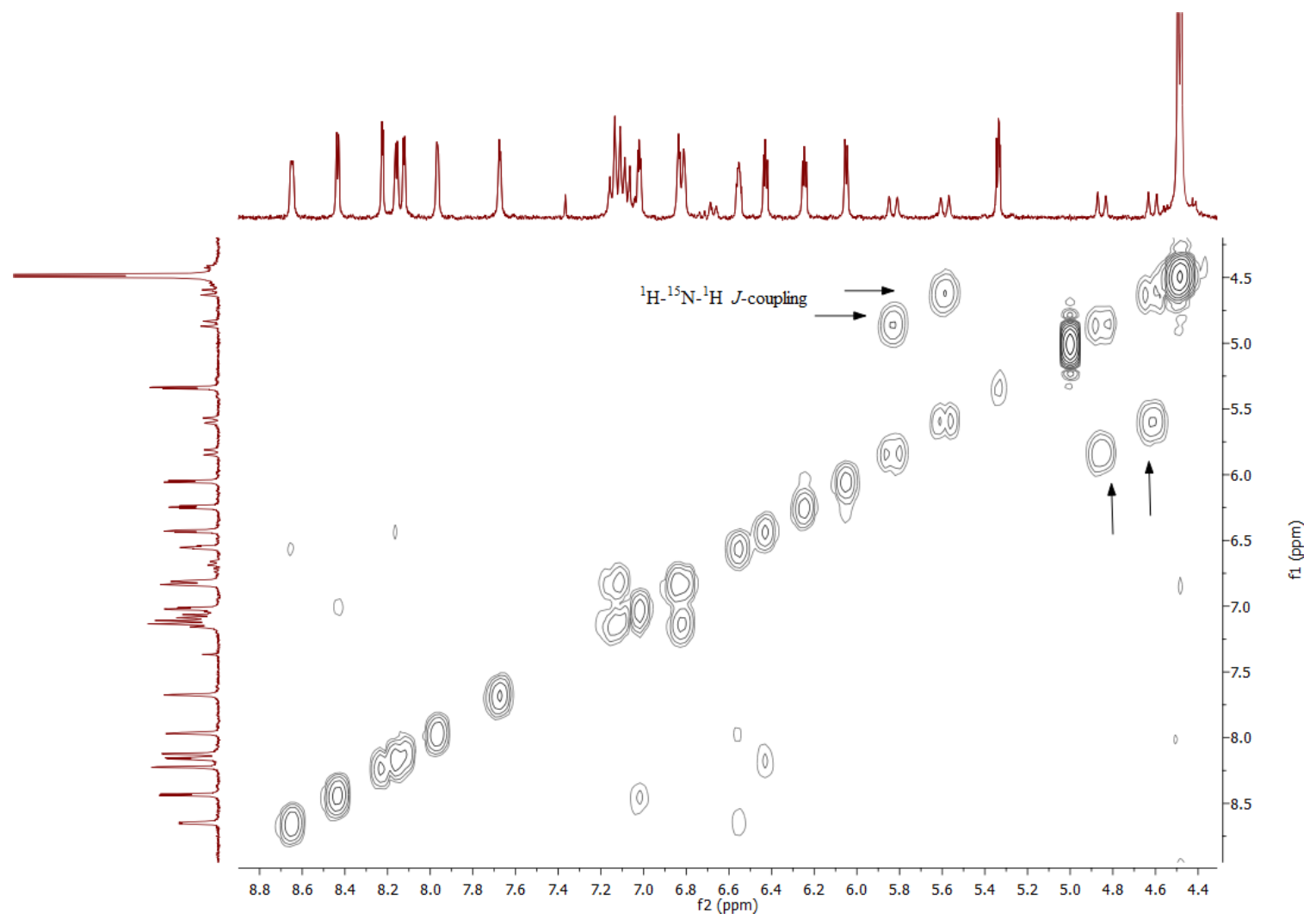

Figure 2.19. ${ }^{1} \mathrm{H}$ gCOSY spectrum of $\left\{\left[\kappa^{3}-\mathrm{C}(\mathrm{pz})_{4}\right] \mathrm{Ru}\left[\mathrm{P}\left(\mathrm{OCH}_{2}\right)_{3} \mathrm{CEt}\right](\mathrm{Cl})\left({ }^{15} \mathrm{NH}_{2} \mathrm{Ph}\right)\right\}\{\mathrm{OTf}\}$ $\left({ }^{15} \mathrm{~N}-5\right)$ in $\mathrm{CD}_{2} \mathrm{Cl}_{2}$.

Cyclic voltammograms of $\mathbf{3}$ and $\mathbf{5}$ were acquired (Scheme 2.12). It was found that the cationic complex $\mathbf{5}$ is more electron-deficient than the neutral complex 3. Complex $\mathbf{3}$ exhibits a reversible $\mathrm{Ru}(\mathrm{III} / \mathrm{II})$ potential at $0.71 \mathrm{~V}$ (vs. NHE) while the $\mathrm{E}_{1 / 2}$ for $\mathbf{5}$ is positive of $\mathbf{3}$ at $1.17 \mathrm{~V}$. 


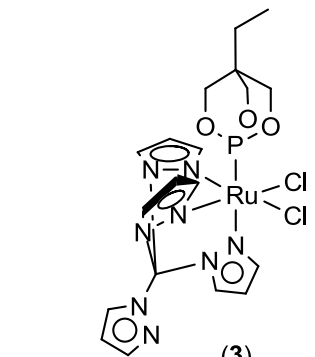

(3)

$E_{1 / 2}$

$0.71 \mathrm{~V}$

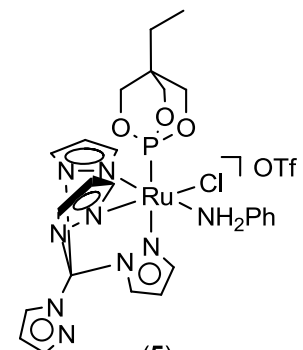

(5)

$1.17 \mathrm{~V}$

Scheme 2.12. Reversible Ru(III/II) potentials for complexes 3 and 5. Data from cyclic voltammetry in acetonitrile with reversible potentials $\left(\mathrm{E}_{1 / 2}\right)$ reported vs NHE.

The triflate anion of 5 can be replaced by tetrakis[(3,5-trifluoromethyl)phenyl]borate $\left(\mathrm{BAr}_{4}^{\prime}\right) . \mathrm{BAr}_{4}{ }^{\prime}$ is far less coordinating than OTf and is expected to facilitate the study of electrophilic cationic fragments. Another advantage of this anion exchange is that $\mathrm{BAr}_{4}{ }^{\prime}$ can enhance solubility in less-polar organic solvents such as diethyl ether.

$\left\{\left[\kappa^{3}-\mathrm{C}(\mathrm{pz})_{4}\right] \mathrm{Ru}\left[\mathrm{P}\left(\mathrm{OCH}_{2}\right)_{3} \mathrm{CEt}\right](\mathrm{Cl})\left(\mathrm{NH}_{2} \mathrm{Ph}\right)\right\}\left\{\mathrm{BAr}_{4}{ }_{4}\right\}(\mathbf{6})$ is produced in $\sim 80 \%$ isolated yield by stirring complex 5 and $\mathrm{NaBAr}_{4}{ }^{\prime}$ at room temperature in $\mathrm{CH}_{2} \mathrm{Cl}_{2}$ (Scheme 2.13). Complete replacement of OTf by $\mathrm{BAr}_{4}{ }^{\prime}$ is indicated by the ${ }^{19} \mathrm{~F}$ NMR spectrum with the disappearance of the resonance for OTf at $-80 \mathrm{ppm}$ and appearance of the resonance for $\mathrm{BAr}_{4}{ }_{4}$ at $-62.8 \mathrm{ppm}$ in $\mathrm{CDCl}_{3}$ (Figure 2.20). The doublets for bound $\mathrm{PhNH}_{2}$ are observed in ${ }^{1} \mathrm{H}$ NMR spectrum (Figure 2.21) and confirmed by ${ }^{1} \mathrm{H}$ gCOSY (Figure 2.22) in $\mathrm{CDCl}_{3}$. The coordination of aniline is also confirmed by an isotopic labeling experiment. By introducing ${ }^{15} \mathrm{~N}$-aniline, the doublets for bound $\mathrm{PhNH}_{2}$ are split by ${ }^{1} \mathrm{H}_{-}{ }^{15} \mathrm{~N} J$-coupling, exhibiting two sets of doublet of doublets with larger ${ }^{1} J_{\mathrm{NH}}(73 \mathrm{~Hz})$ and smaller ${ }^{2} J_{\mathrm{HH}}(11$ $\mathrm{Hz}$ ) in ${ }^{1} \mathrm{H}$ NMR spectrum in tetrahydrofuran- $d_{8}$ (Figure 2.23 ). Characterization by ${ }^{31} \mathrm{P}$ NMR and ${ }^{13} \mathrm{C}$ NMR spectroscopy in tetrahydrofuran- $d_{8}$ (Figure 2.24 and Figure 2.25, respectively) also indicates clean isolation of complex $\mathbf{6}$. 


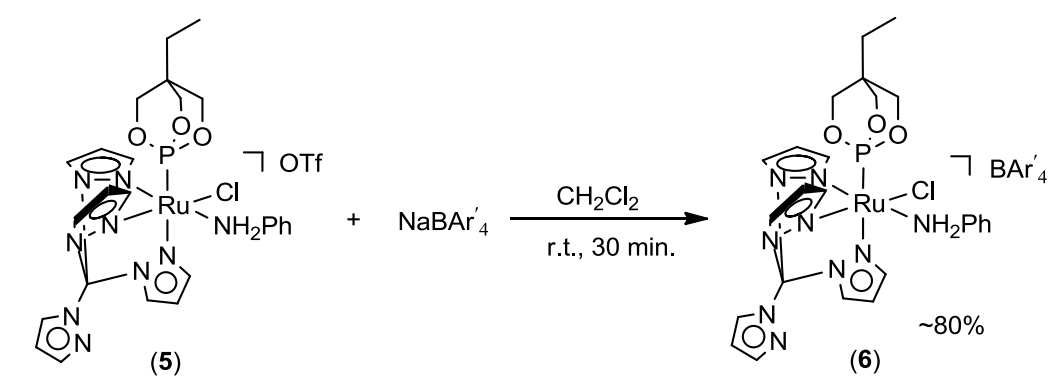

Scheme 2.13. Synthesis of $\left\{\left[\kappa^{3}-\mathrm{C}(\mathrm{pz})_{4}\right] \mathrm{Ru}\left[\mathrm{P}\left(\mathrm{OCH}_{2}\right)_{3} \mathrm{CEt}\right](\mathrm{Cl})\left(\mathrm{NH}_{2} \mathrm{Ph}\right)\right\}\left(\mathrm{BAr}_{4}^{\prime}\right)(\mathbf{6})$.
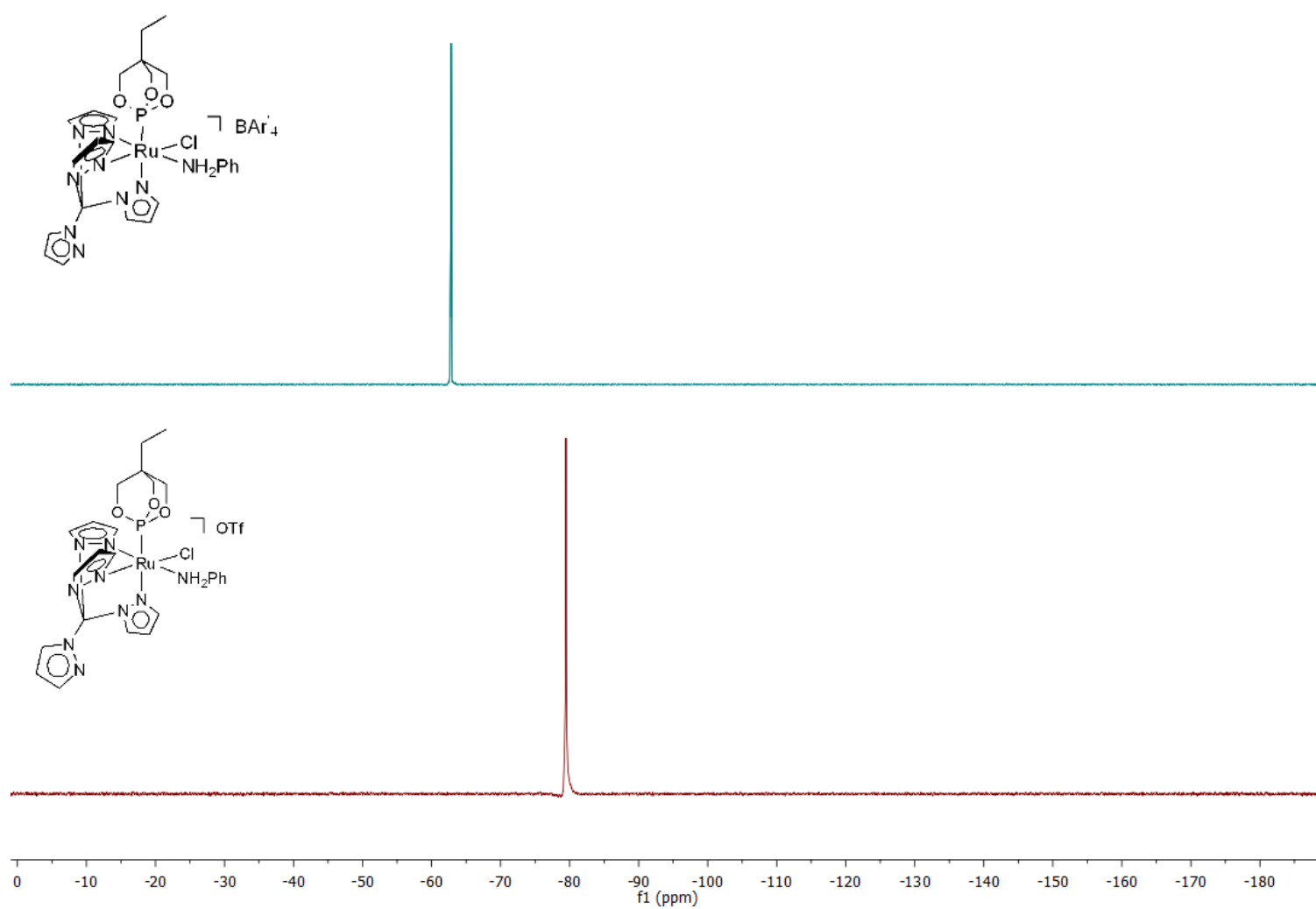

Figure 2.20. ${ }^{19} \mathrm{~F}$ NMR spectra of complex 5 (bottom) and complex $\mathbf{6}$ (top) in $\mathrm{CDCl}_{3}$. 


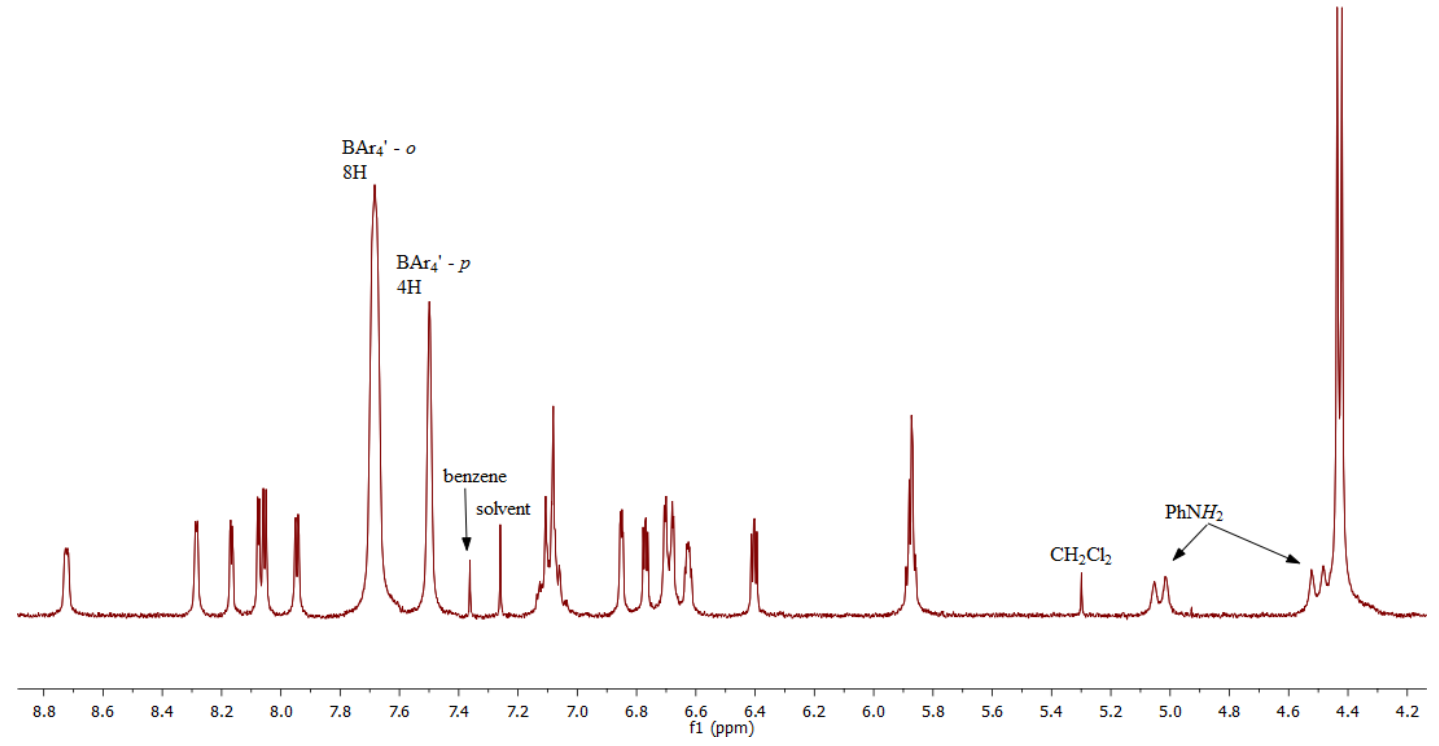

Figure 2.21. ${ }^{1} \mathrm{H}$ NMR spectrum of $\left\{\left[\kappa^{3}-\mathrm{C}(\mathrm{pz})_{4}\right] \mathrm{Ru}\left[\mathrm{P}\left(\mathrm{OCH}_{2}\right)_{3} \mathrm{CEt}\right](\mathrm{Cl})\left(\mathrm{NH}_{2} \mathrm{Ph}\right)\right\}\left\{\mathrm{BAr}_{4}{ }^{\prime}\right\}$ (6) in $\mathrm{CDCl}_{3}$.

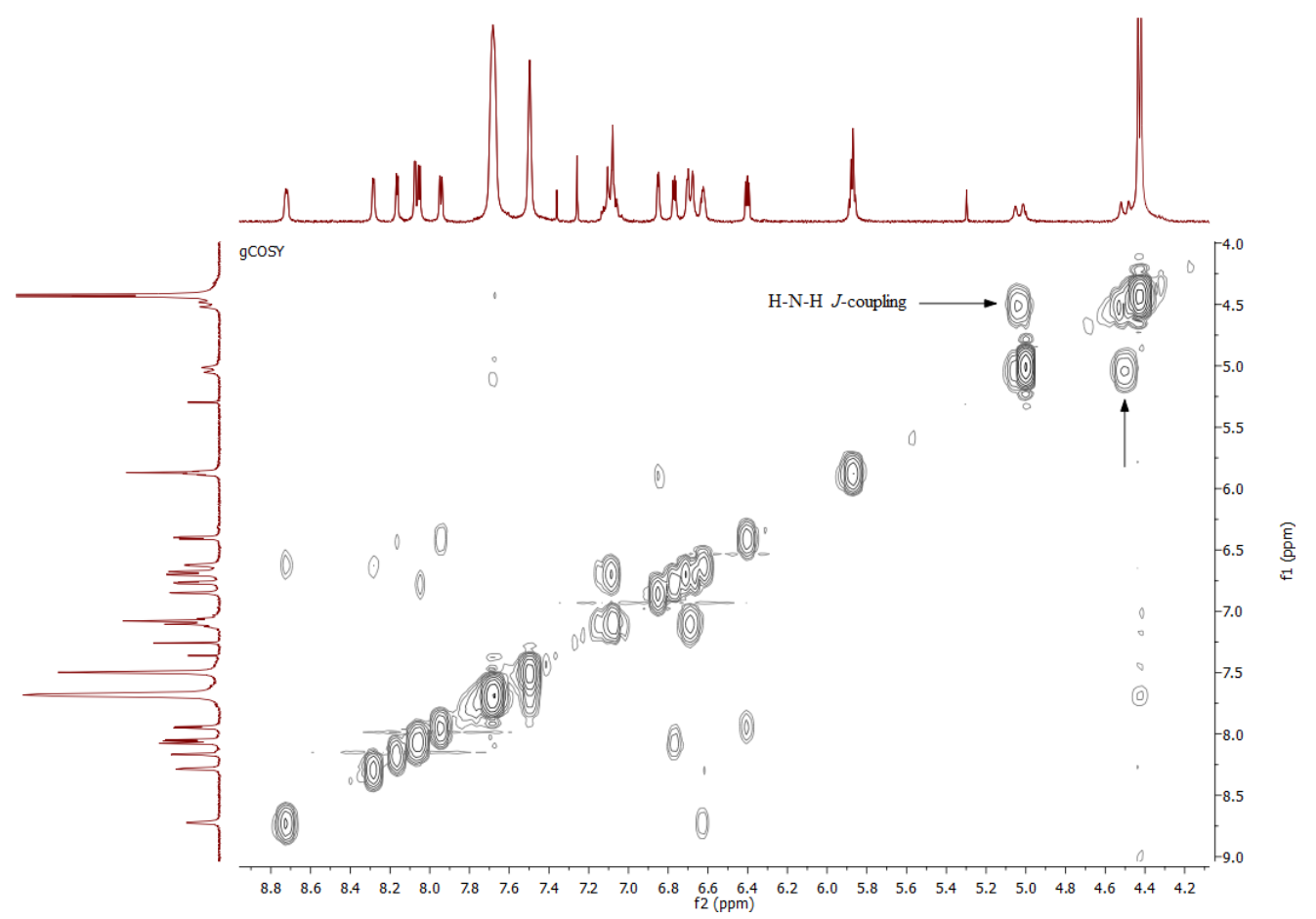

Figure 2.22. ${ }^{1} \mathrm{H}$ gCOSY spectrum of $\left\{\left[\kappa^{3}-\mathrm{C}(\mathrm{pz})_{4}\right] \mathrm{Ru}\left[\mathrm{P}\left(\mathrm{OCH}_{2}\right)_{3} \mathrm{CEt}\right](\mathrm{Cl})\left(\mathrm{NH}_{2} \mathrm{Ph}\right)\right\}\left\{\mathrm{BAr}_{4}^{\prime}\right\}$ (6) in $\mathrm{CDCl}_{3}$. 


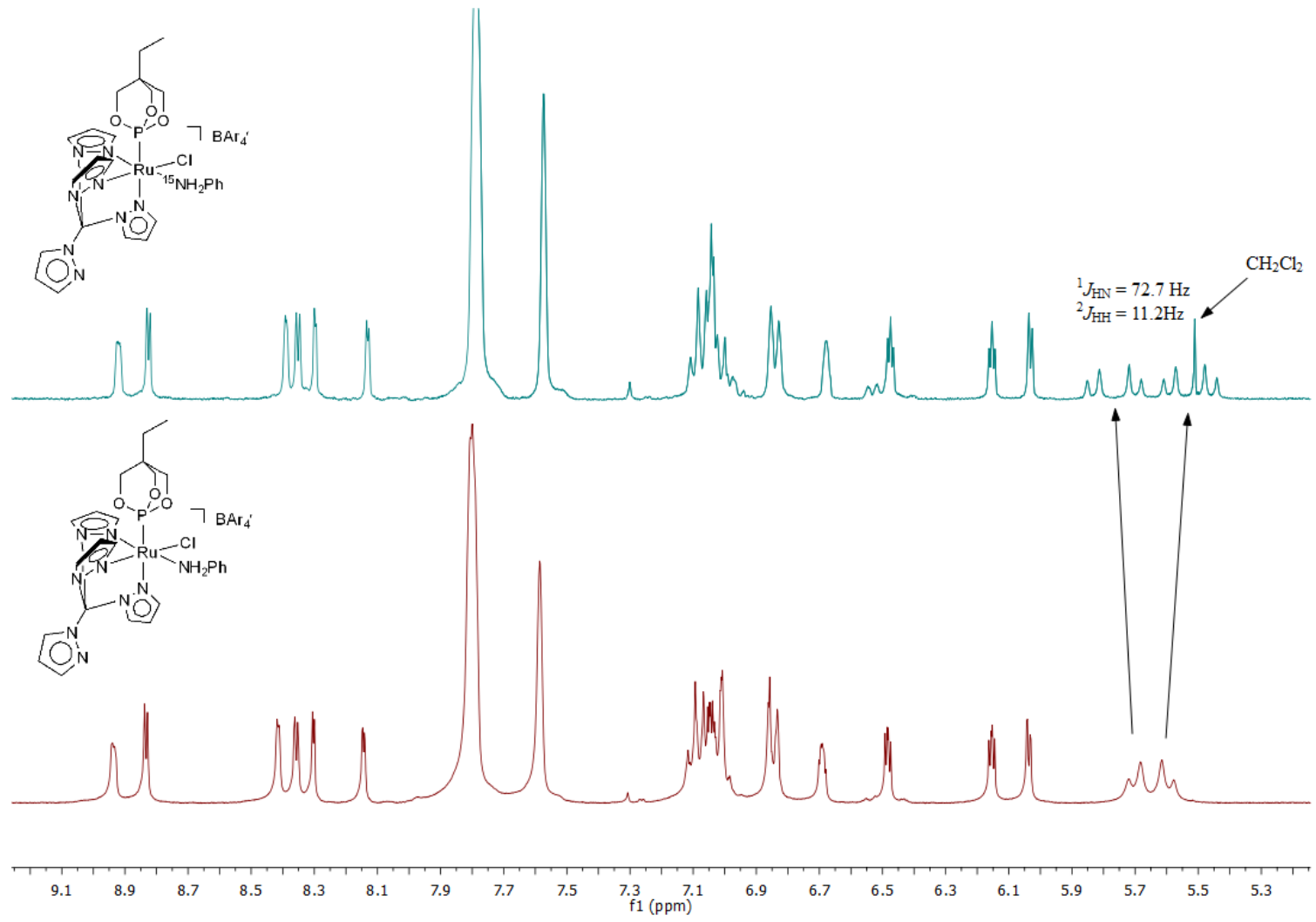

Figure 2.23. Different splitting patters in the ${ }^{1} \mathrm{H}$ NMR spectra of complex 6 in THF- $d_{8}$ : before (bottom) and after (top) introducing ${ }^{15} \mathrm{NH}_{2} \mathrm{Ph}$.

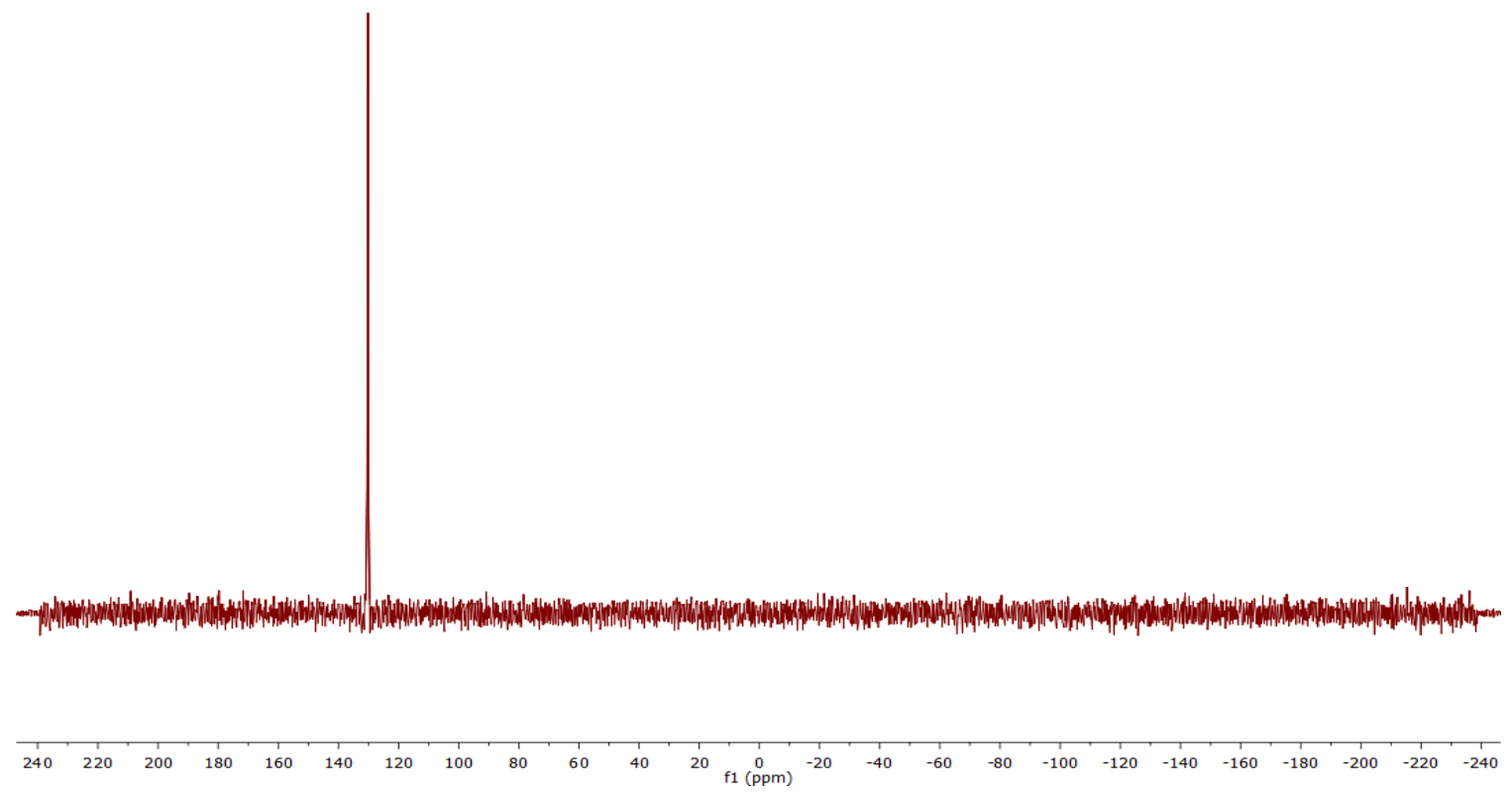

Figure 2.24. ${ }^{31} \mathrm{P}$ NMR spectrum of complex 6 in THF- $d_{8}$. 


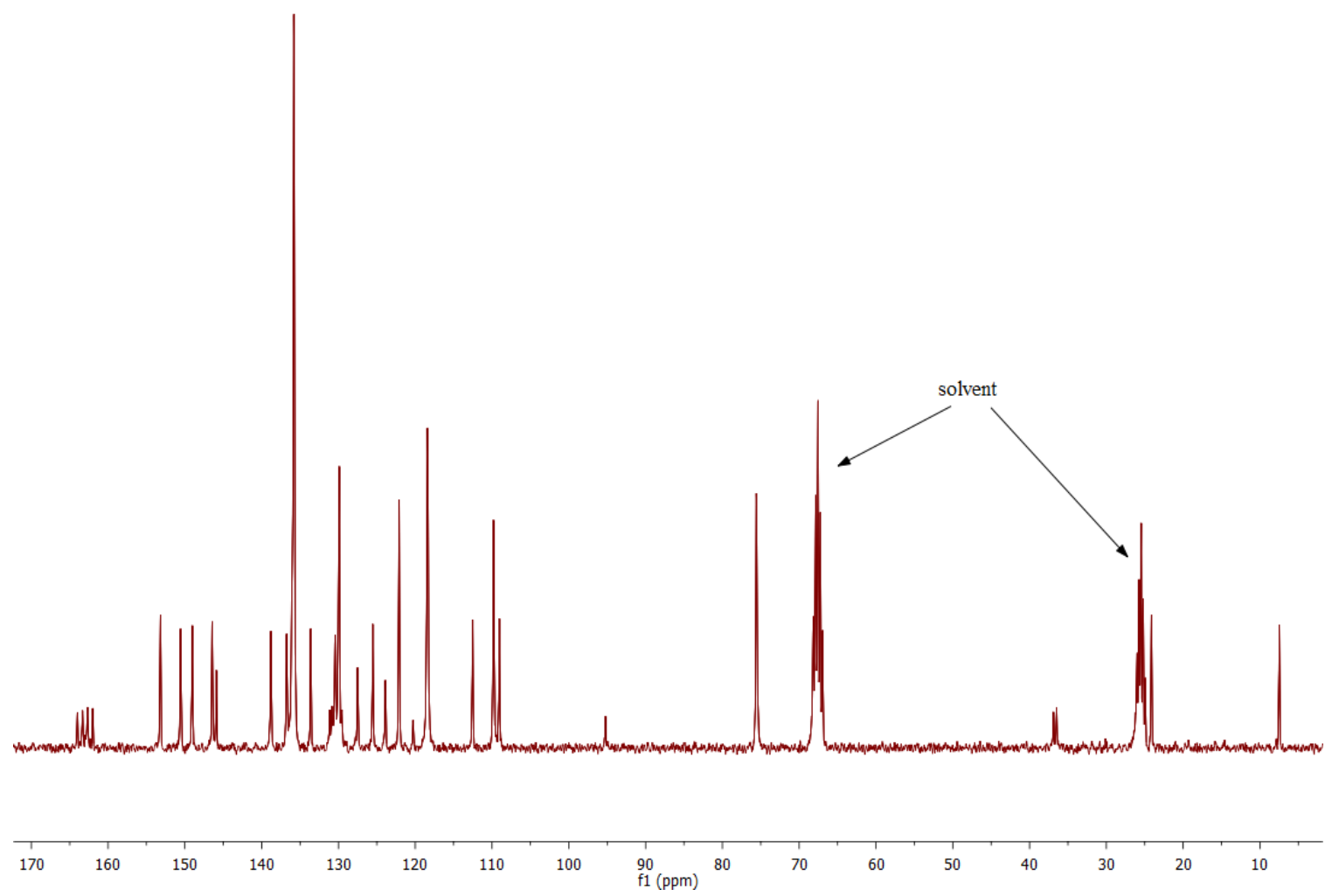

Figure 2.25. ${ }^{13} \mathrm{C}$ NMR spectrum of $\left\{\left[\kappa^{3}-\mathrm{C}(\mathrm{pz})_{4}\right] \mathrm{Ru}\left[\mathrm{P}\left(\mathrm{OCH}_{2}\right)_{3} \mathrm{CEt}\right](\mathrm{Cl})\left(\mathrm{NH}_{2} \mathrm{Ph}\right)\right\}\left\{\mathrm{BAr}_{4}{ }^{\prime}\right\}$ (6) in THF- $d_{8}$.

The $\mathrm{Cl}$ ligand of complex $\mathbf{5}$ is displaced upon reaction with TlOTf in tetrahydrofuran. If aniline is present the bis-aniline complex $\left\{\left[\kappa^{3}-\right.\right.$ $\left.\left.\mathrm{C}(\mathrm{pz})_{4}\right] \mathrm{Ru}\left[\mathrm{P}\left(\mathrm{OCH}_{2}\right)_{3} \mathrm{CEt}\right]\left(\mathrm{PhNH}_{2}\right)_{2}\right\}\{\mathrm{OTf}\}_{2}(7)$ is the product (Scheme 2.14). Complex 7 can also be synthesized by reaction of dimeric complex 4 , TlOTf and excess aniline in tetrahydrofuran (Scheme 2.14) in $~ 70 \%$ isolated yield. 


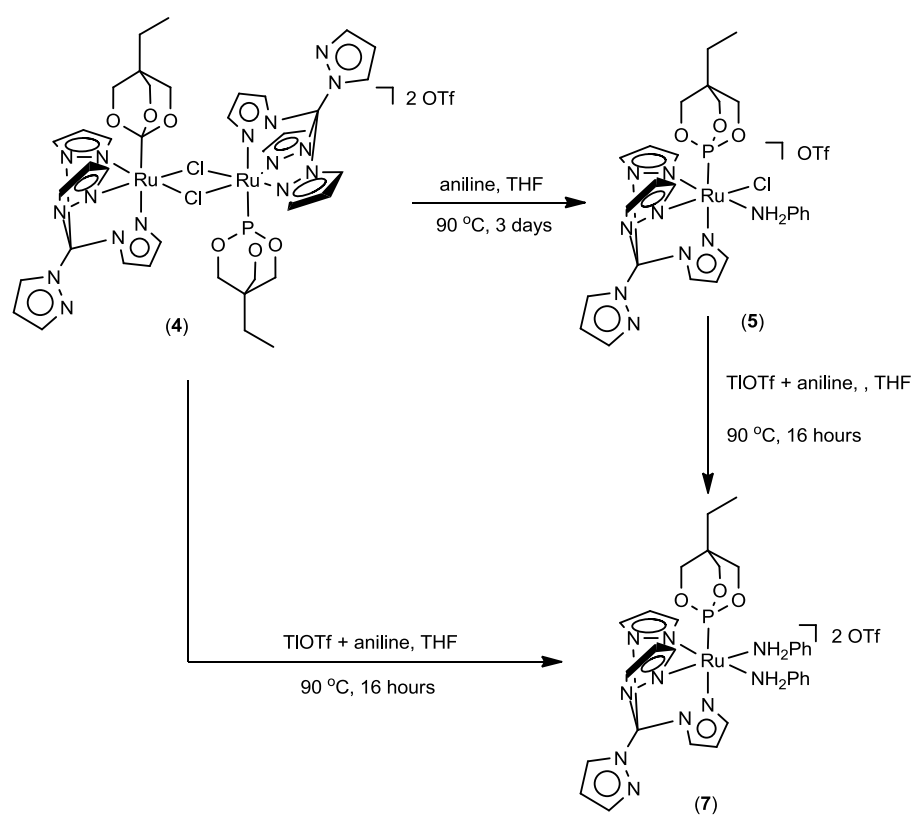

Scheme 2.14. Synthesis of $\left\{\left[\kappa^{3}-\mathrm{C}(\mathrm{pz})_{4}\right] \mathrm{Ru}\left[\mathrm{P}\left(\mathrm{OCH}_{2}\right)_{3} \mathrm{CEt}\right]\left(\mathrm{PhNH}_{2}\right)_{2}\right\}\{\mathrm{OTf}\}_{2}(7)$.

Characterization by ${ }^{1} \mathrm{H}$ NMR spectroscopy in $\mathrm{CD}_{2} \mathrm{Cl}_{2}$ shows that complex 7 has $\mathrm{C}_{\mathrm{s}}$ molecular symmetry (Figure 2.26), indicating the two aniline ligands are symmetry equivalent. The two doublets $\left({ }^{2} J_{\mathrm{HH}}=12 \mathrm{~Hz}\right)$ for bound $\mathrm{PhNH} H_{2}$ are observed at $5.4 \mathrm{ppm}$ and $5.7 \mathrm{ppm}$ in ${ }^{1} \mathrm{H}$ NMR spectrum. The $\mathrm{H}-\mathrm{N}-\mathrm{H}$ coupling for bound $\mathrm{PhNH}_{2}$ is confirmed by ${ }^{1} \mathrm{H}$ gCOSY (Figure 2.27) in $\mathrm{CD}_{2} \mathrm{Cl}_{2}$. The singlet for OTf at $81.0 \mathrm{ppm}$ in the ${ }^{19} \mathrm{~F} \mathrm{NMR}$ spectrum of complex 7 in $\mathrm{CD}_{2} \mathrm{Cl}_{2}$ indicates that the OTf is uncoordinated (Figure 2.28). Characterization by ${ }^{31} \mathrm{P}$ NMR and ${ }^{13} \mathrm{C}$ NMR spectroscopy in acetonitrile- $d_{3}$ (Figure 2.29 and Figure 2.30, respectively) also indicates the clean isolation of complex 7. 

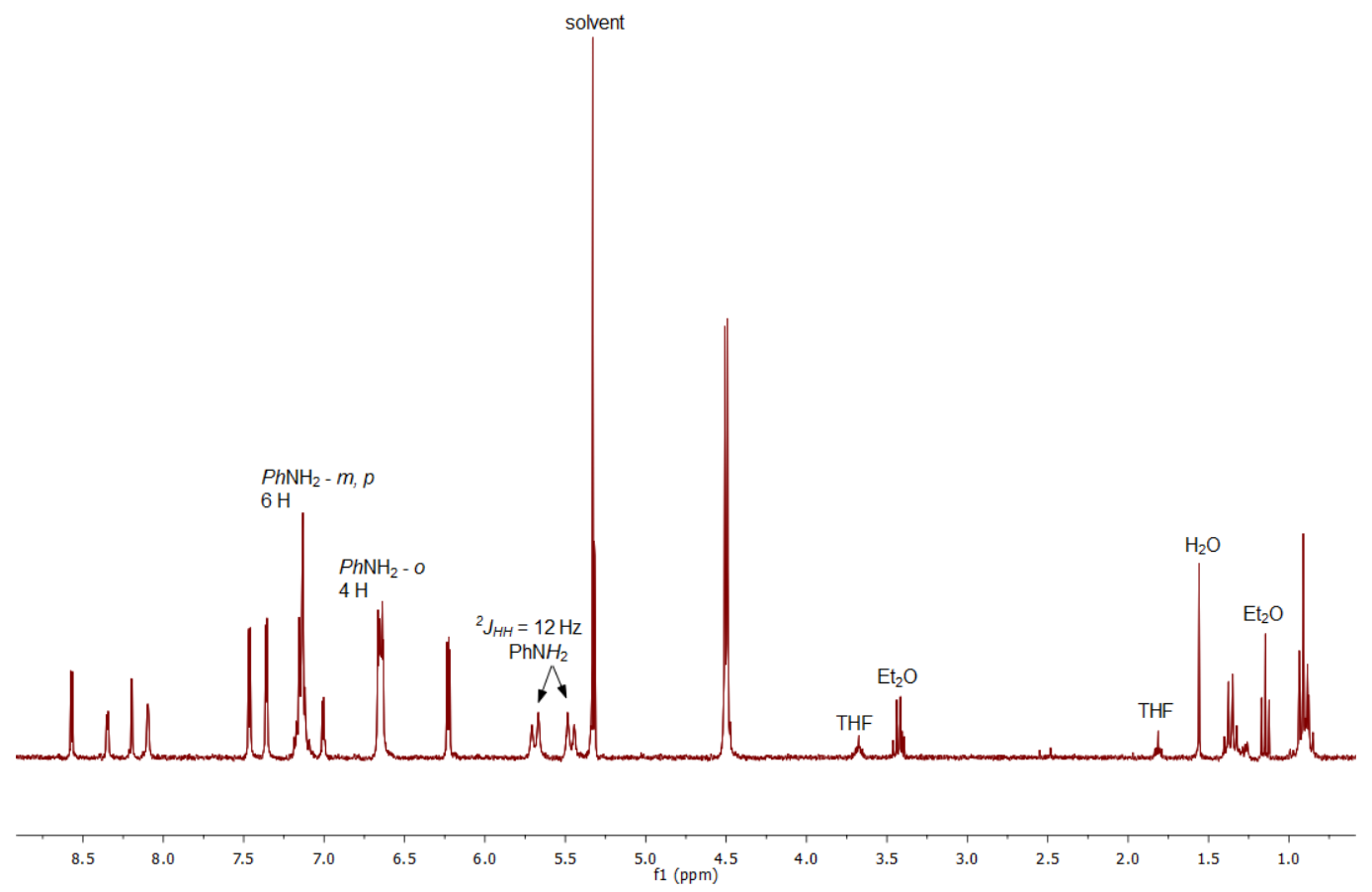

Figure 2.26. ${ }^{1} \mathrm{H} \mathrm{NMR}$ spectrum of $\left\{\left[\kappa^{3}-\mathrm{C}(\mathrm{pz})_{4}\right] \mathrm{Ru}\left[\mathrm{P}\left(\mathrm{OCH}_{2}\right)_{3} \mathrm{CEt}\right]\left(\mathrm{PhNH}_{2}\right)_{2}\right\}\{\mathrm{OTf}\}_{2}(7)$ in $\mathrm{CD}_{2} \mathrm{Cl}_{2}$.

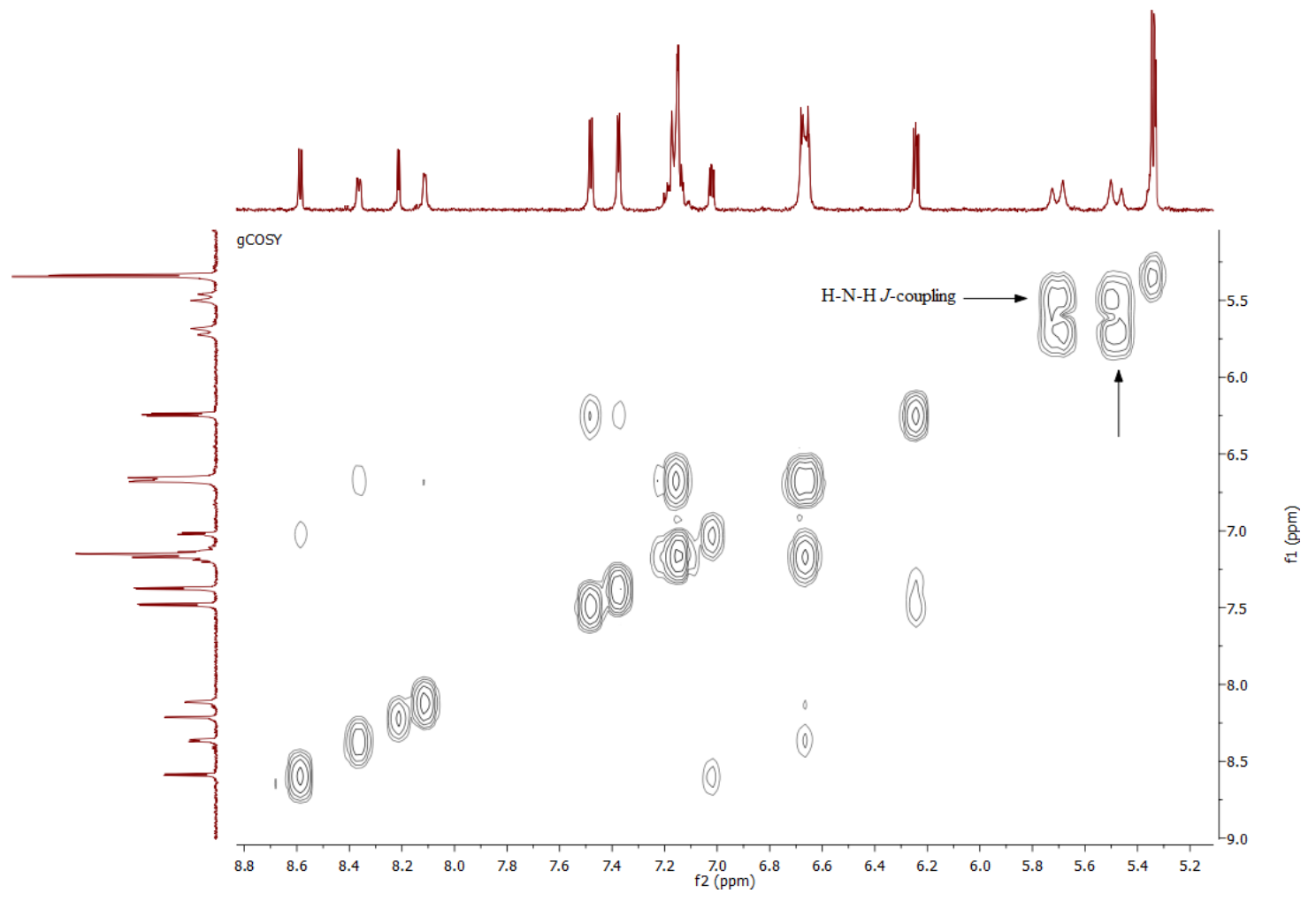

Figure 2.27. ${ }^{1} \mathrm{H}$ gCOSY spectrum of complex 7 in $\mathrm{CD}_{2} \mathrm{Cl}_{2}$. 


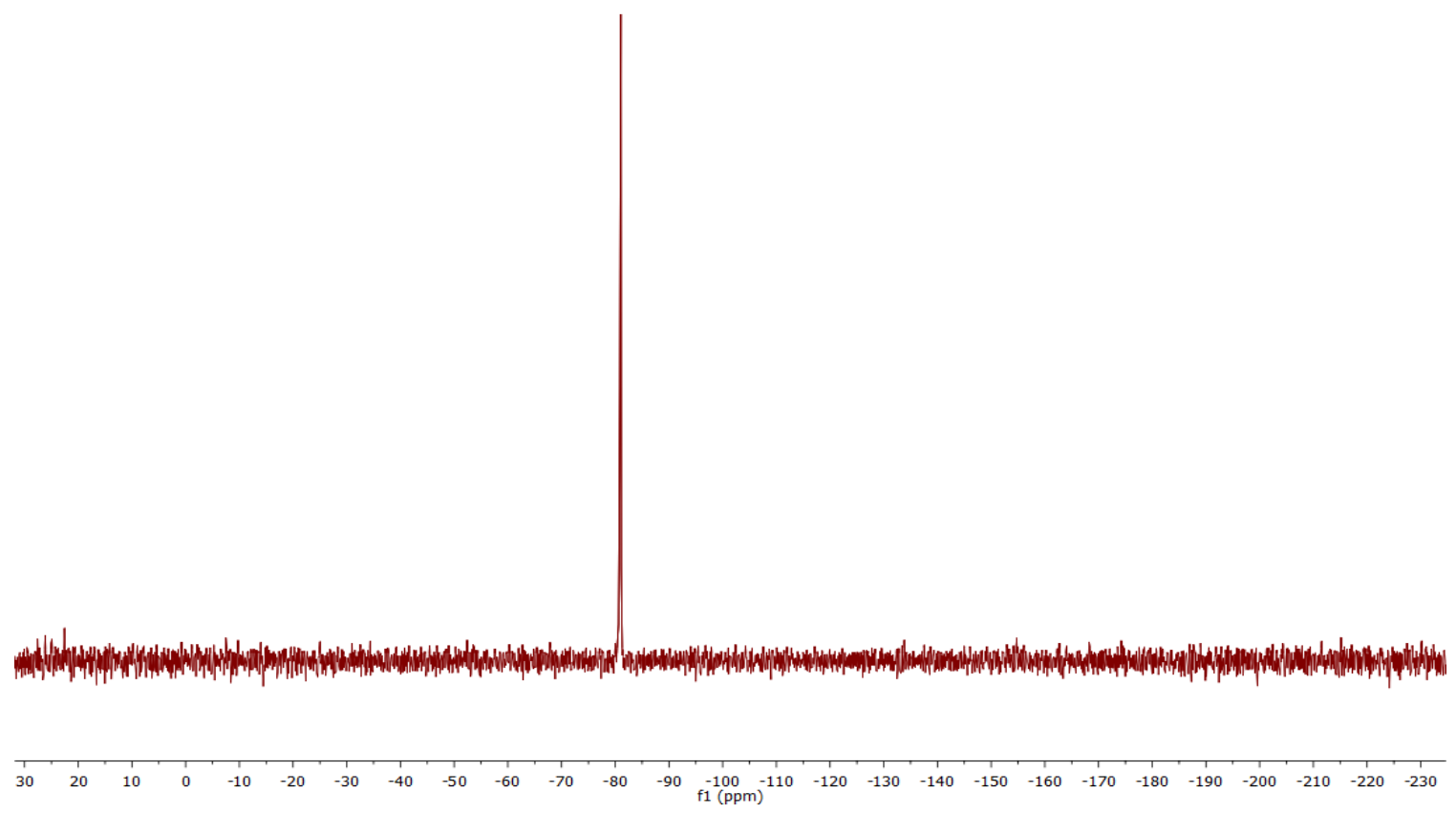

Figure 2.28. ${ }^{19} \mathrm{~F}$ NMR spectrum of $\left\{\left[\kappa^{3}-\mathrm{C}(\mathrm{pz})_{4}\right] \mathrm{Ru}\left\{\mathrm{P}\left(\mathrm{OCH}_{2}\right)_{3} \mathrm{CEt}\right\}\left(\mathrm{PhNH}_{2}\right)_{2}\right\}\{\mathrm{OTf}\}_{2}$ (7) in $\mathrm{CD}_{2} \mathrm{Cl}_{2}$.

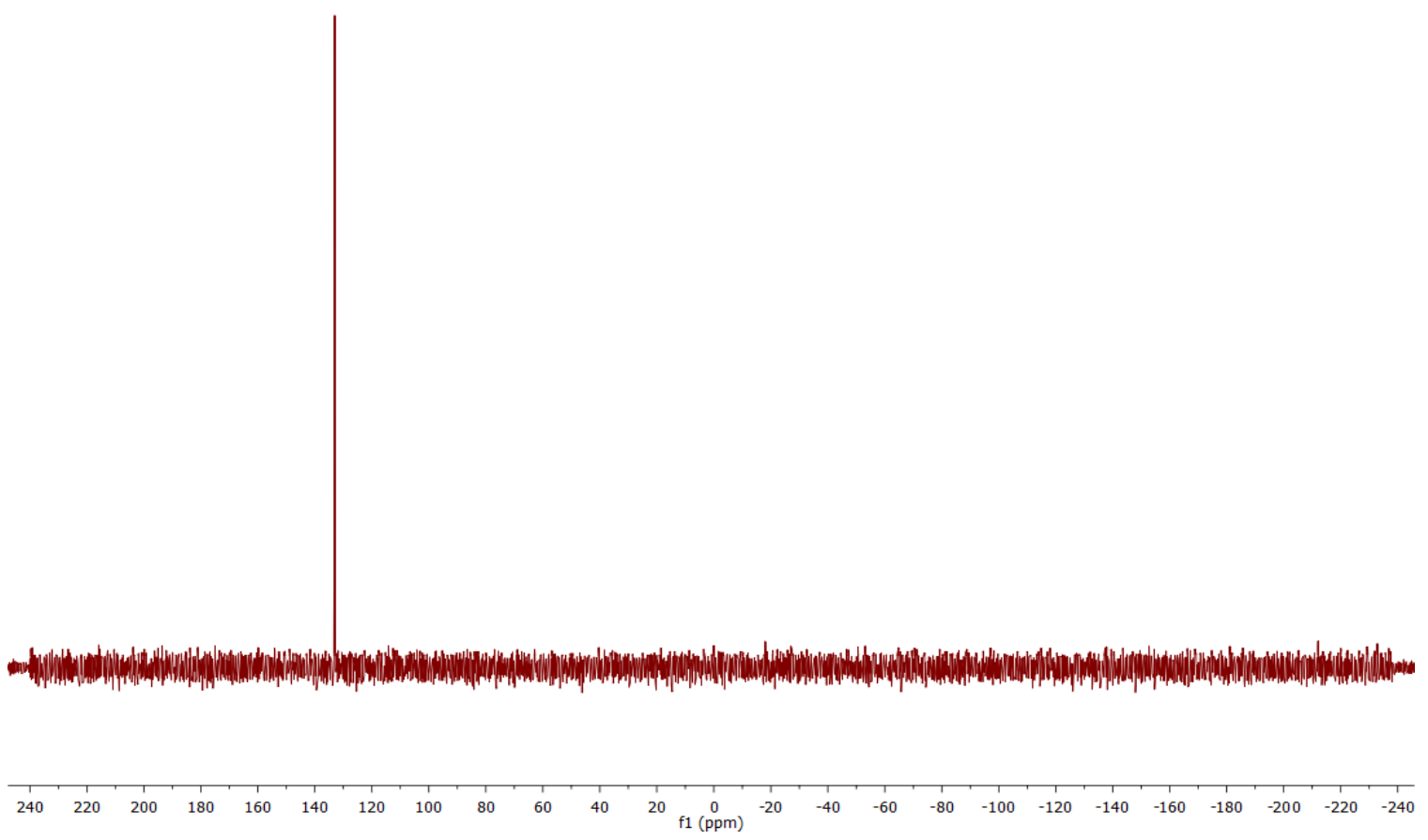

Figure 2.29. ${ }^{31} \mathrm{P} \mathrm{NMR}$ spectrum of $\left\{\left[\kappa^{3}-\mathrm{C}(\mathrm{pz})_{4}\right] \mathrm{Ru}\left\{\mathrm{P}\left(\mathrm{OCH}_{2}\right)_{3} \mathrm{CEt}\right\}\left(\mathrm{PhNH}_{2}\right)_{2}\right\}\{\mathrm{OTf}\}_{2}$ (7) in $\mathrm{CD}_{3} \mathrm{CN}$. 

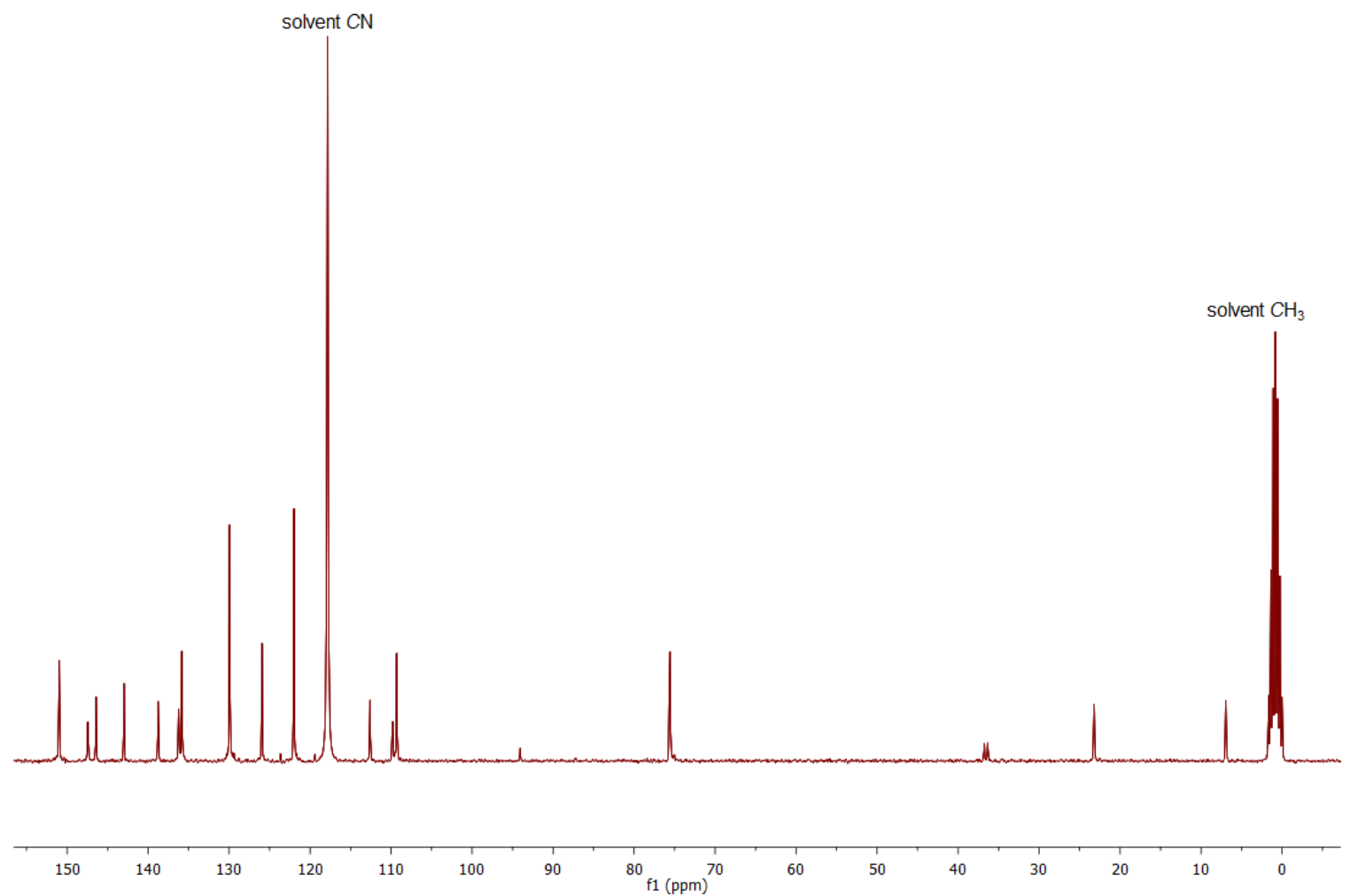

Figure 2.30. ${ }^{13} \mathrm{C}$ NMR spectrum of $\left\{\left[\kappa^{3}-\mathrm{C}(\mathrm{pz})_{4}\right] \mathrm{Ru}\left\{\mathrm{P}\left(\mathrm{OCH}_{2}\right)_{3} \mathrm{CEt}\right\}\left(\mathrm{PhNH}_{2}\right)_{2}\right\}\{\mathrm{OTf}\}_{2}(\mathbf{7})$ in $\mathrm{CD}_{3} \mathrm{CN}$. 


\subsubsection{Efforts toward the synthesis of $\mathrm{Ru}(\mathrm{II})$-anilido complexes}

The synthesis of $\mathrm{Ru}$-aniline complexes provides a potential route to desired $\mathrm{Ru}$-anilido (M-X type) complexes via deprotonation. The $\mathrm{p} K_{\mathrm{a}}$ of unbound aniline is $\sim 30$ (in DMSO). ${ }^{105}$ The deprotonation of Ru-aniline complexes $\mathbf{5}$ and $\mathbf{6}$ by a variety of bases was conducted successfully in polar aprotic solvents at $-78{ }^{\circ} \mathrm{C}$ (Scheme 2.15 ,

Table 2.1). Upon addition of base, an instantaneous color change occurs. The solution of $\mathrm{Ru}$-anilido complex is red while the solution of Ru-aniline complexes is pale yellow. When sodium hydride is used as base, effervescence is observed, likely due to the production of $\mathrm{H}_{2}$.

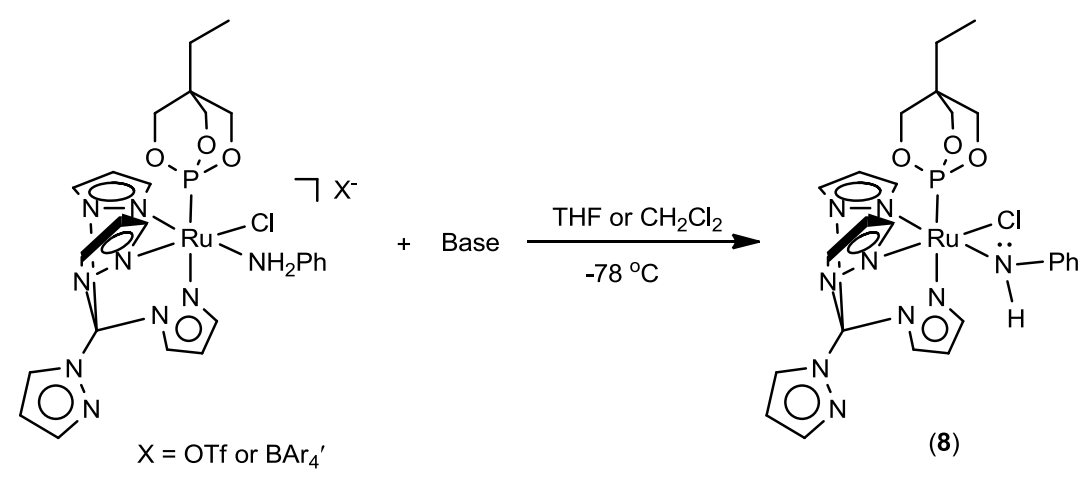

Scheme 2.15. Deprotonation of Ru-aniline complexes.

Table 2.1. Results of the deprotonation of Ru-aniline complexes in different solvent/base pairs.

\begin{tabular}{c|cccc}
\hline & NaHMDS & NaH & LDA & n-BuLi \\
\hline Tetrahydrofuran & yes & yes & yes & yes \\
Dichloromethane & yes & $-^{a}$ & yes & $-{ }^{a}$ \\
\hline
\end{tabular}

${ }^{a}$ Not conducted.

In the ${ }^{1} \mathrm{H}$ NMR spectrum, the two doublets for coordinated aniline protons disappear upon addition of base, which indicates deprotonation of aniline (Figure 2.31). The 
resonance for anilido proton is not observable because of coincidental overlap with other resonances at room temperature (see below).

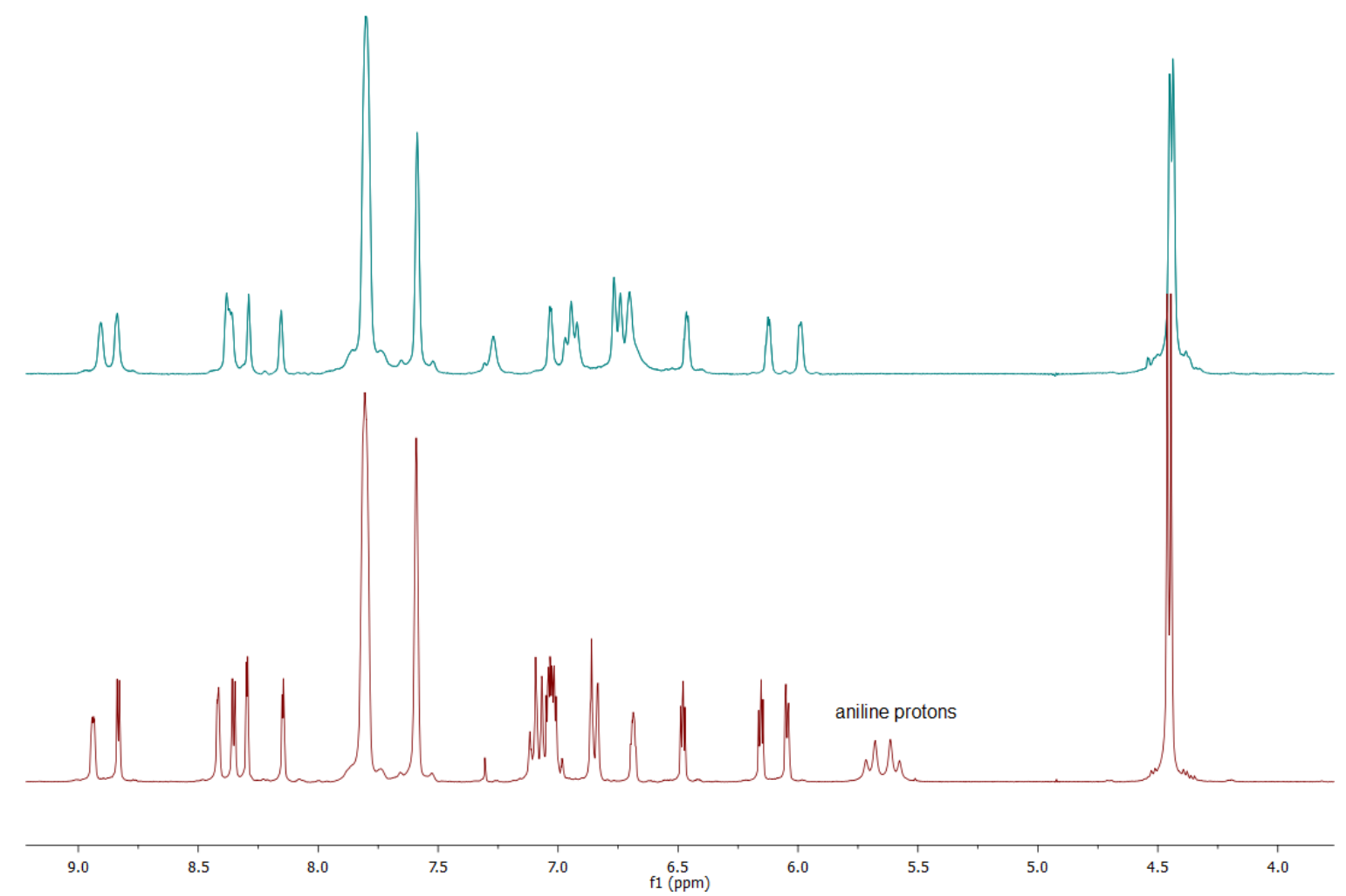

Figure 2.31. Comparison of the ${ }^{1} \mathrm{H}$ NMR spectra of complex 6 and in-situ generation of complex 8 in THF- $d_{8}$ : before (bottom) and after (top) addition of base.

In the variable temperature (VT) ${ }^{1} \mathrm{H}$ NMR spectra of complex 8 , a singlet shifts downfield with decreasing temperature (Figure 2.32). If the ${ }^{15} \mathrm{~N}$-labeled ligand is present, the resonance for the anilido proton should be a doublet due to coupling between $\mathrm{H}$ and ${ }^{15} \mathrm{~N}$. In the VT study of ${ }^{15} \mathrm{~N}$-labeled complex 8 , a doublet $\left({ }^{1} J_{\mathrm{NH}}=80 \mathrm{~Hz}\right)$ shifts downfield with decreasing temperature (Figure 2.33). Thus, the broad singlet has been confirmed as the resonance for the anilido proton. The VT study confirms that the resonance for anilido proton of unlabeled $\mathbf{8}$ cannot be observed because of coincidental overlap with the resonance for methylene protons of the phosphite ligand. 


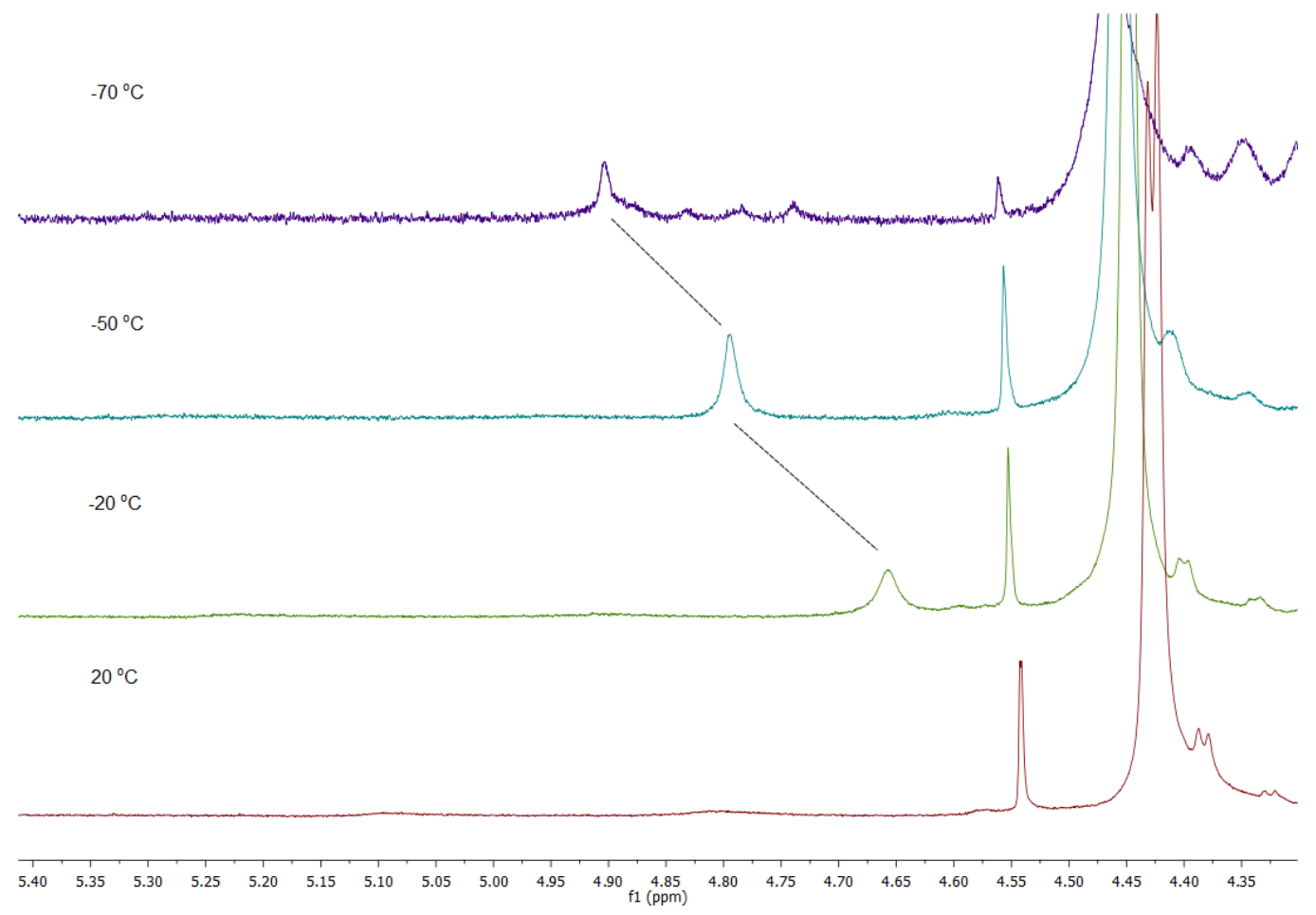

Figure 2.32. Variable temperature study of complex 8 in THF- $d_{8}$ : the resonance for the anilido proton shifts downfield with decreasing temperature.

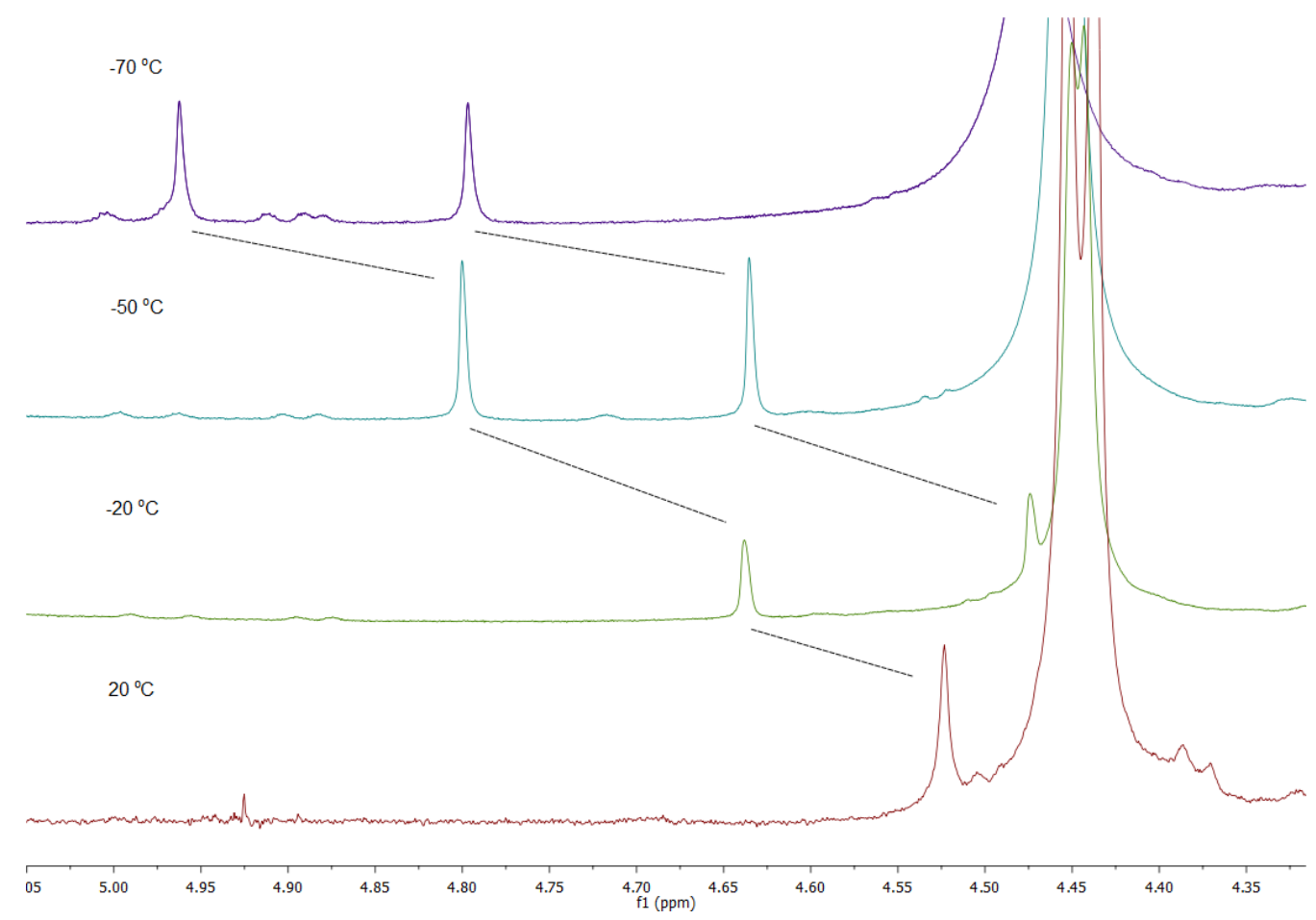

Figure 2.33. Variable temperature study of complex $8-{ }^{15} \mathrm{~N}$ in THF- $d_{8}$ : the doublet $\left({ }^{1} J_{\mathrm{NH}}\right.$ $=80 \mathrm{~Hz}$ ) for the anilido proton shifts downfield with decreasing temperature. 
Although the deprotonation was successful, isolation of complex $\mathbf{8}$ was not accomplished despite repeated attempts using various strategies. Monitoring complex 8 by NMR revealed protonation occurs even at low temperatures, to reform the complex $\mathbf{5}$. Ultimately, decomposition to multiple intractable products occurs. The proton source for the anilido-to-aniline transformation remains unclear. To avoid the influence of trace water in solvent and the $\mathrm{Si}-\mathrm{OH}$ group of glass, the solvent was distilled over $\mathrm{Na} /$ benzophenone and glassware was treated by trimethylsilyl chloride. However, transformation to the aniline complex and decomposition were still observed.

The bis-aniline complex 7 can be deprotonated by NaHMDS in methylene chloride at low temperature (Scheme 2.16). An instantaneous color change from yellow to maroon is observed upon addition of two equivalents of NaHMDS to 7. In the ${ }^{1} \mathrm{H}$ NMR spectrum of the reaction mixture, the resonances for the aniline protons disappear, likely indicating that both aniline ligands are deprotonated (Figure 2.34). Similar to complex $\mathbf{8}$, attempts to isolate complex 9 were not successful. Complex 9 decomposes more rapidly than complex $\mathbf{8}$, and the formation of complex $\mathbf{7}$ is not observed during decomposition. Other bases (LDA, n-BuLi, 2,6-lutidine) were tried, and results analogous to NaHMDS were observed except for 2,6-lutidine, which does not deprotonate complex 7.

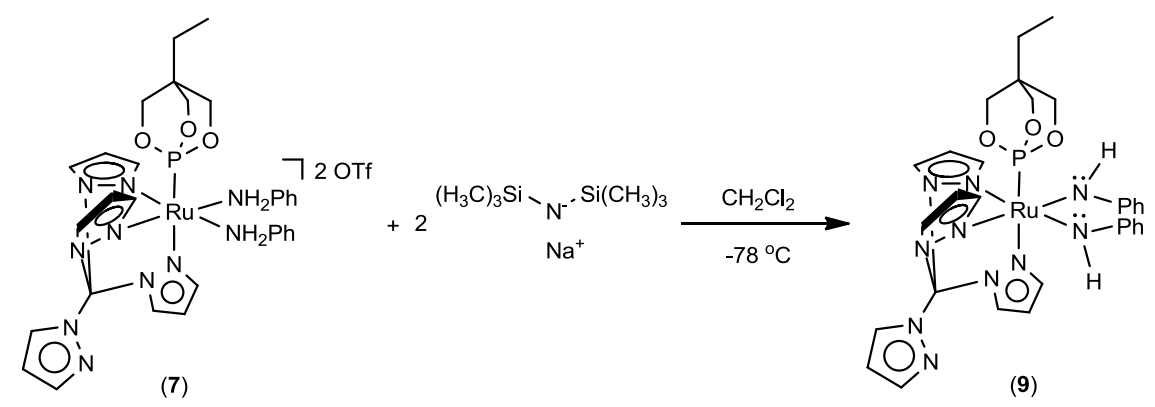

Scheme 2.16. Deprotonation of $\left\{\left[\kappa^{3}-\mathrm{C}(\mathrm{pz})_{4}\right] \mathrm{Ru}\left[\mathrm{P}\left(\mathrm{OCH}_{2}\right)_{3} \mathrm{CEt}\right]\left(\mathrm{PhNH}_{2}\right)_{2}\right\}\{\mathrm{OTf}\}_{2}$ (7). 


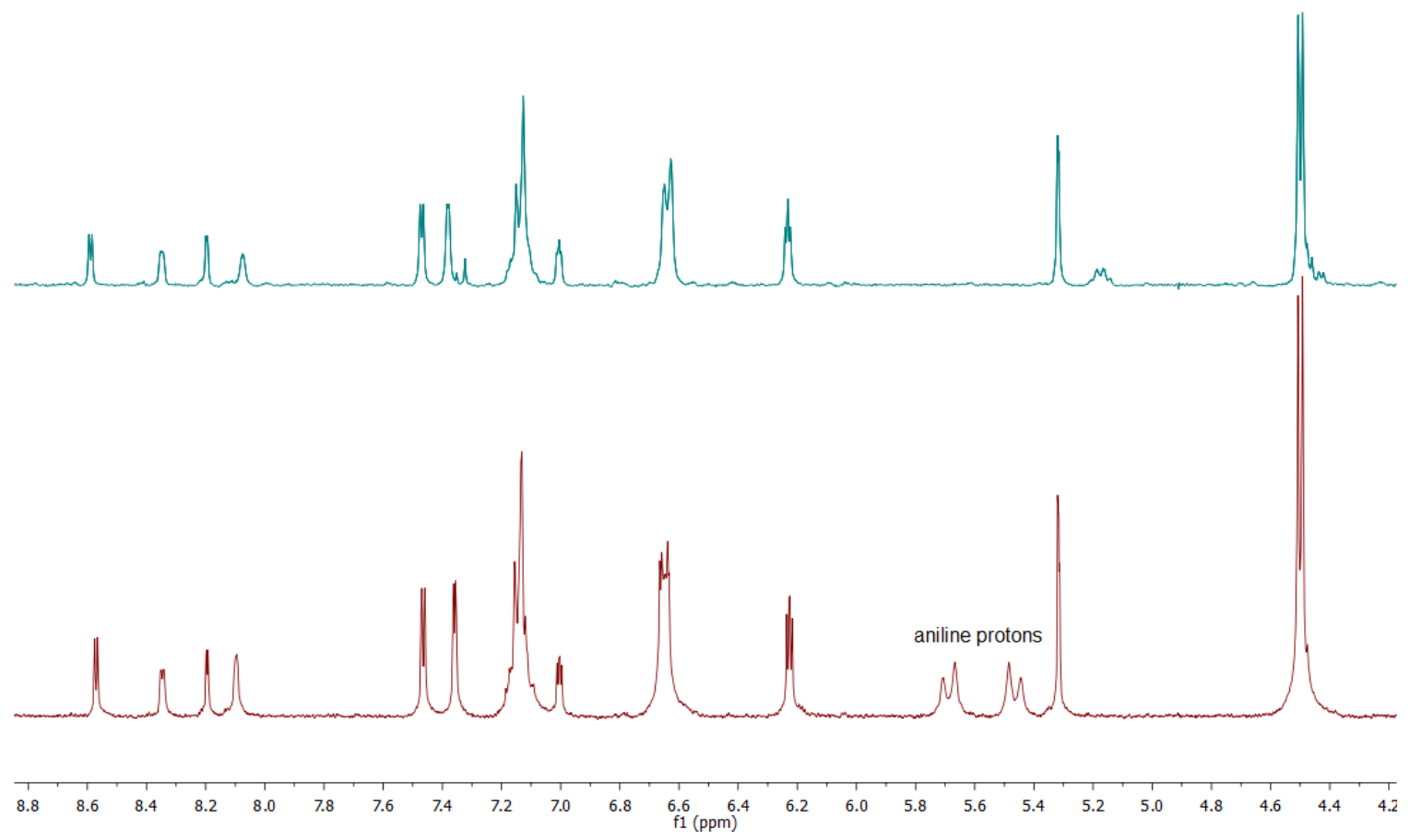

Figure 2.34. Comparison of the ${ }^{1} \mathrm{H}$ NMR spectra of complex 7 and in-situ generation of complex 9 in methylene chloride- $d_{2}$ : before (bottom) and after (top) addition of base. 


\subsubsection{Synthesis and reactivity of a $\mathrm{Ru}(\mathrm{II})$-methanol complex}

Given the inability to isolate a $\mathrm{Ru}(\mathrm{II})$ aniline complex, we sought the preparation of $\mathrm{Ru}(\mathrm{II})$ methanol complexes. It was anticipated that a methoxide complex might be more stable due to reduced basicity relative to an anilide complex. Similar to the synthesis of complex 7, the reaction of dimer 4 with three equivalents of silver triflate in methanol at $90 \quad{ }^{\circ} \mathrm{C} \quad$ produces the $\mathrm{Ru}-$ methanol complex $\left\{\left[\kappa^{3}-\right.\right.$ $\left.\mathrm{C}(\mathrm{pz})_{4} \mathrm{Ru}\left[\mathrm{P}\left(\mathrm{OCH}_{2}\right)_{3} \mathrm{CEt}\right](\mathrm{MeOH})_{2}\right\}\{\mathrm{OTf}\}_{2}(\mathbf{1 0})$ (Scheme 2.17). Complex 10 is not very stable and decomposes in solvents other than methanol.

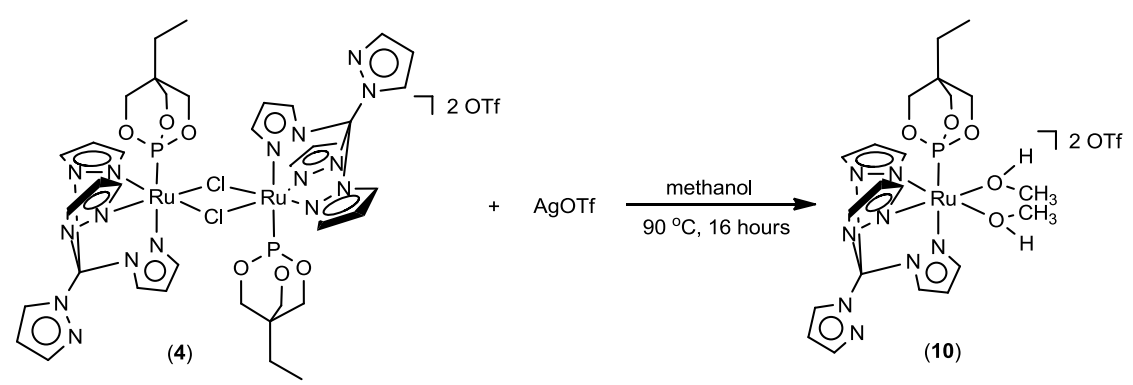

Scheme 2.17. Synthesis of $\left\{\left[\kappa^{3}-\mathrm{C}(\mathrm{pz})_{4} \mathrm{Ru}\left[\mathrm{P}\left(\mathrm{OCH}_{2}\right)_{3} \mathrm{CEt}\right]\left(\mathrm{CH}_{3} \mathrm{OH}\right)_{2}\right\}(\mathrm{OTf})_{2}(\mathbf{1 0})\right.$.

Characterization of complex $\mathbf{1 0}$ by ${ }^{1} \mathrm{H}$ NMR spectroscopy in methanol- $d_{4}$ indicates $\mathrm{C}_{\mathrm{s}}$ molecular symmetry (Figure 2.35). By preparation of complex $\mathbf{1 0}$ in protio methanol, the resonance for the bound methanol ligand is observed as a singlet at $3.35 \mathrm{ppm}$ in methanol- $d_{4}$. Characterization by ${ }^{31} \mathrm{P}$ NMR spectroscopy in methanol- $d_{4}$ indicates the clean formation of complex 10 (Figure 2.36). 


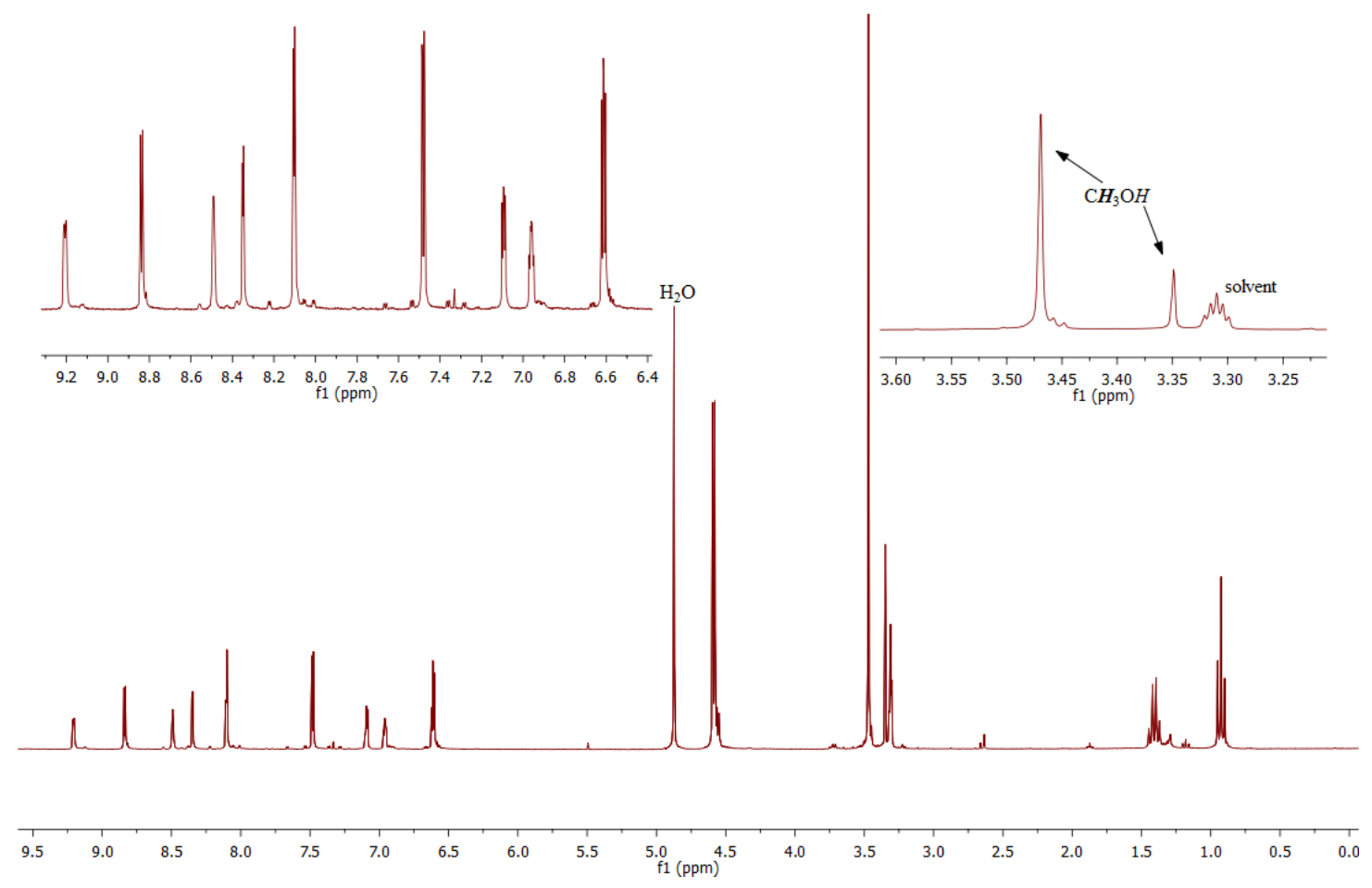

Figure 2.35. ${ }^{1} \mathrm{H}$ NMR spectrum of complex 10 in methanol- $d_{4}$. Complex 10 was synthesized in $\mathrm{CH}_{3} \mathrm{OH}$.

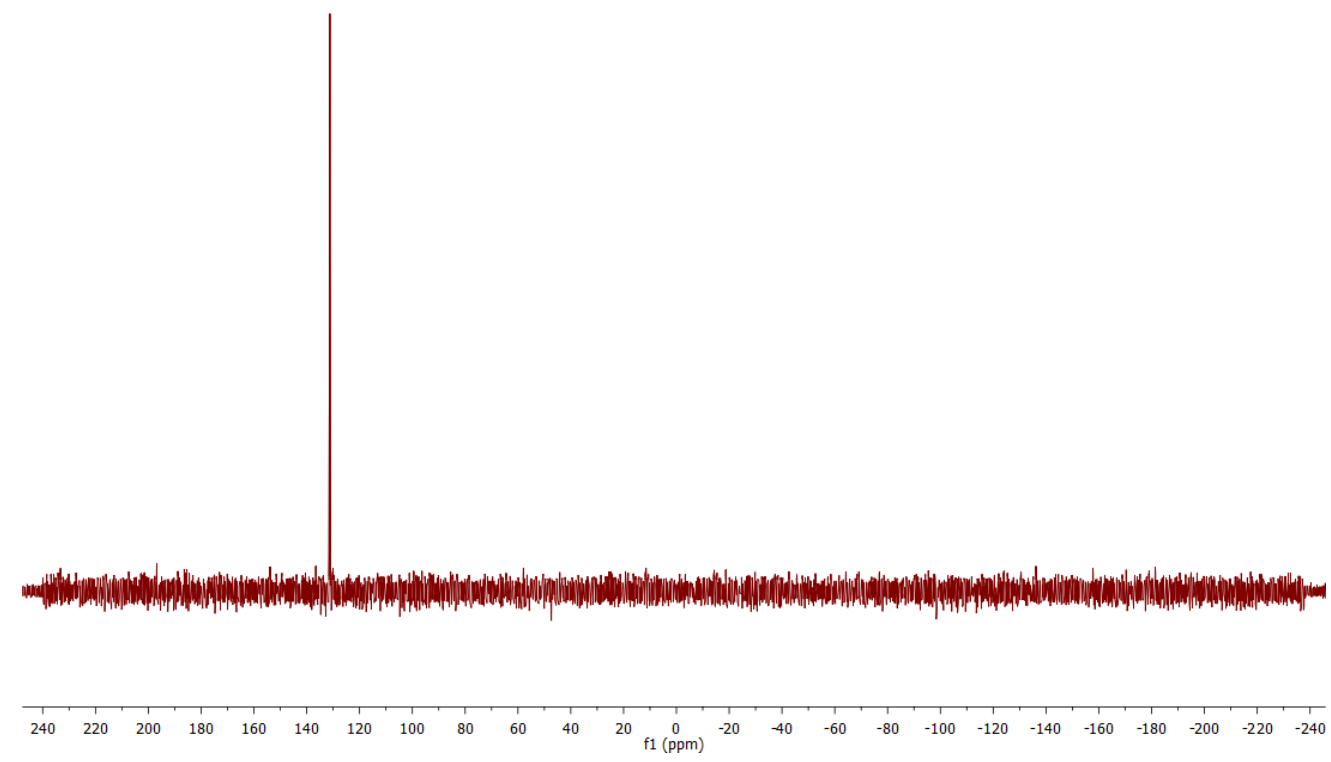

Figure 2.36. ${ }^{31} \mathrm{P}$ NMR spectrum of complex 10 in methanol- $d_{4}$. 


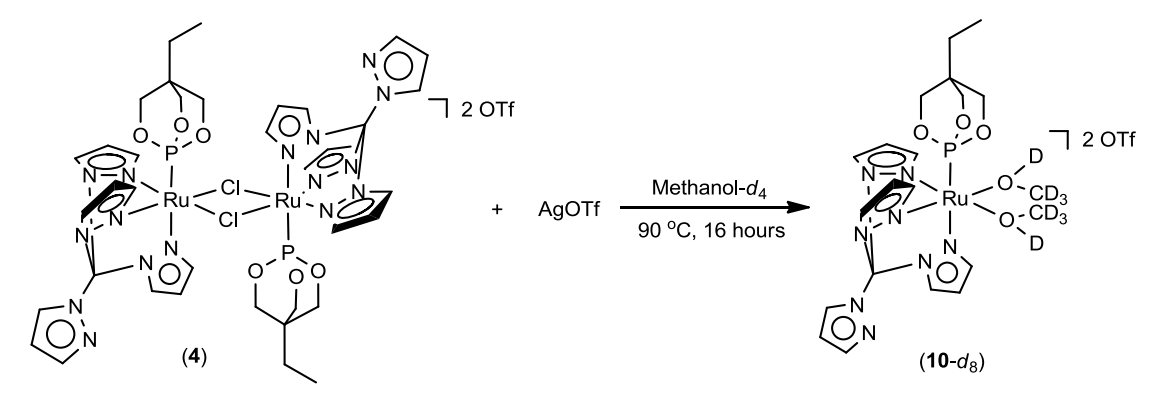

Scheme 2.18. Synthesis of $\left\{\left[\kappa^{3}-\mathrm{C}(\mathrm{pz})_{4} \mathrm{Ru}\left[\mathrm{P}\left(\mathrm{OCH}_{2}\right)_{3} \mathrm{CEt}\right]\left(\mathrm{CD}_{3} \mathrm{OD}\right)_{2}\right\}\{\mathrm{OTf}\}_{2}\left(\mathbf{1 0}-d_{8}\right)\right.$.

The coordination of methanol is confirmed by using deuterated methanol instead of protio methanol in its synthesis (Scheme 2.18). The product 10- $d_{8}$ has two methanol- $d_{4}$ ligands. These deuterated ligands are not ${ }^{1} \mathrm{H}$ NMR active. The comparison of the ${ }^{1} \mathrm{H}$ NMR spectra of complex $\mathbf{1 0}$ and complex $\mathbf{1 0}-d_{8}$ in methanol- $d_{4}$ shows that the two peaks at $3.35 \mathrm{ppm}$ and $3.47 \mathrm{ppm}$, which account for the bound methanol ligand, are not present in the ${ }^{1} \mathrm{H}$ NMR spectrum of complex $\mathbf{1 0}-d_{8}$. This is consistent with the coordination of methanol molecules in complex $\mathbf{1 0}$. 


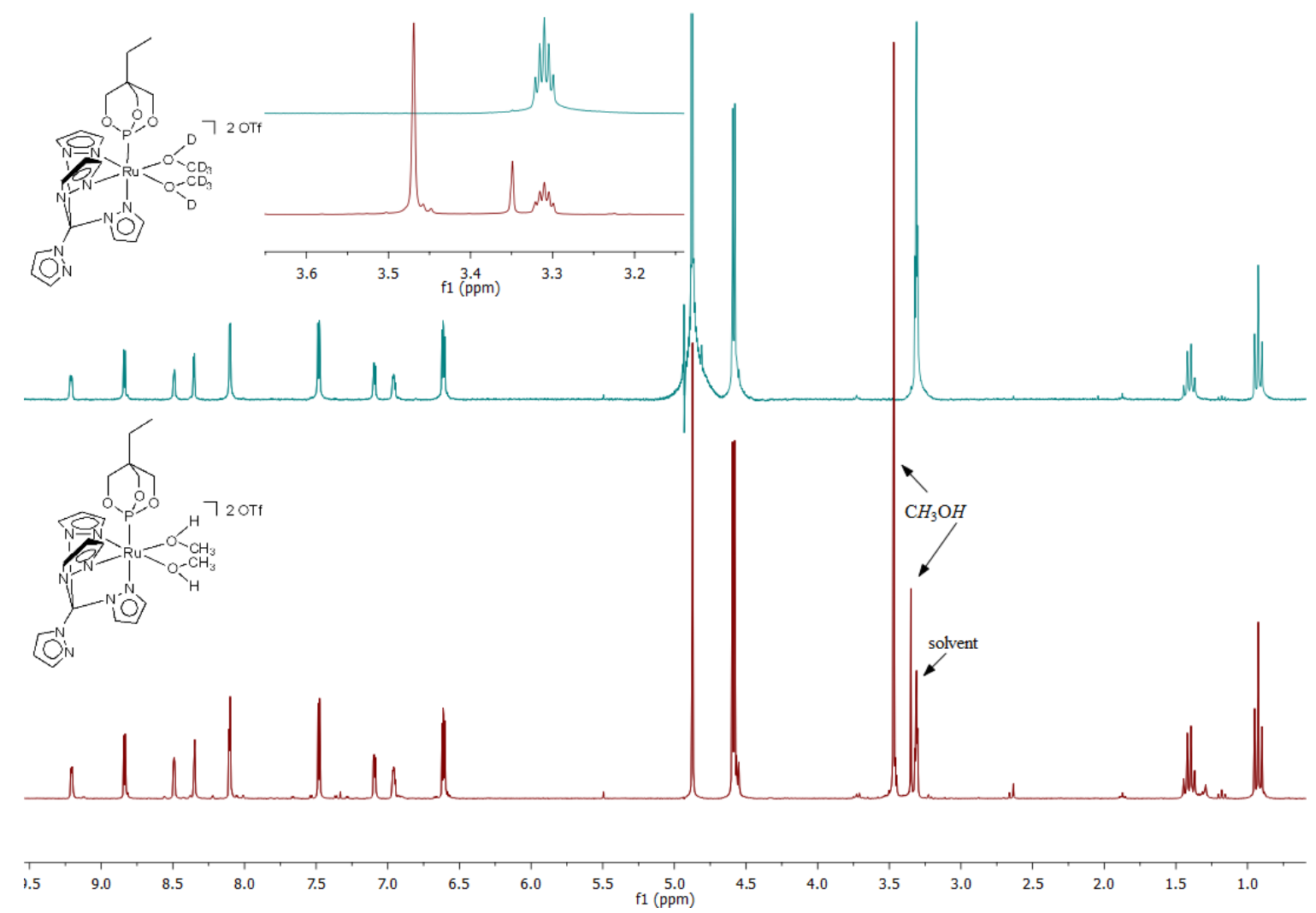

Figure 2.37. Comparison of the ${ }^{1} \mathrm{H}$ NMR spectra of complex 10 (bottom) and 10- $d_{8}$ (top) in methanol- $d_{4}$.

When complex $\mathbf{1 0}$ is in methanol, proton exchange at the hydroxyl group occurs between free and coordinated methanol (Scheme 2.19). In the ${ }^{1} \mathrm{H}$ NMR spectrum of complex $\mathbf{1 0}$ in methanol- $d_{4}$, the integration of $-\mathrm{CH}_{3}$ and $-\mathrm{OH}$ in coordinated methanol is more than 3:1 due to the H/D exchange between complex 10 and deuterated methanol solvent (Figure 2.38). The disappearance of hydroxyl resonance was not observed because complex eventually decomposed. In addition, resonance for the bound methanol proton becomes observable if deuterated complex $\mathbf{1 0}-d_{8}$ is dissolved in protio methanol or ethanol before taking ${ }^{1} \mathrm{H}$ NMR (Figure 2.39). There is no exchange of methyl groups, indicating that ligand exchange is not responsible for the $-\mathrm{OH} / \mathrm{D}$ exchange. 


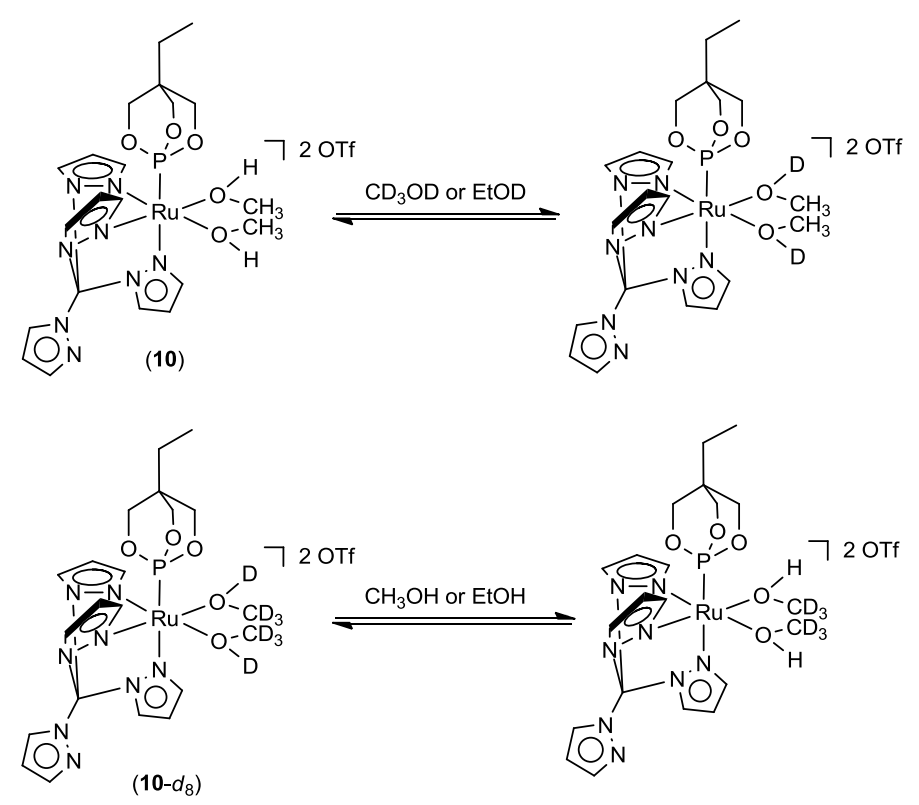

Scheme 2.19. The $-\mathrm{OH} / \mathrm{D}$ exchange between complex 10 and free methanol or ethanol.

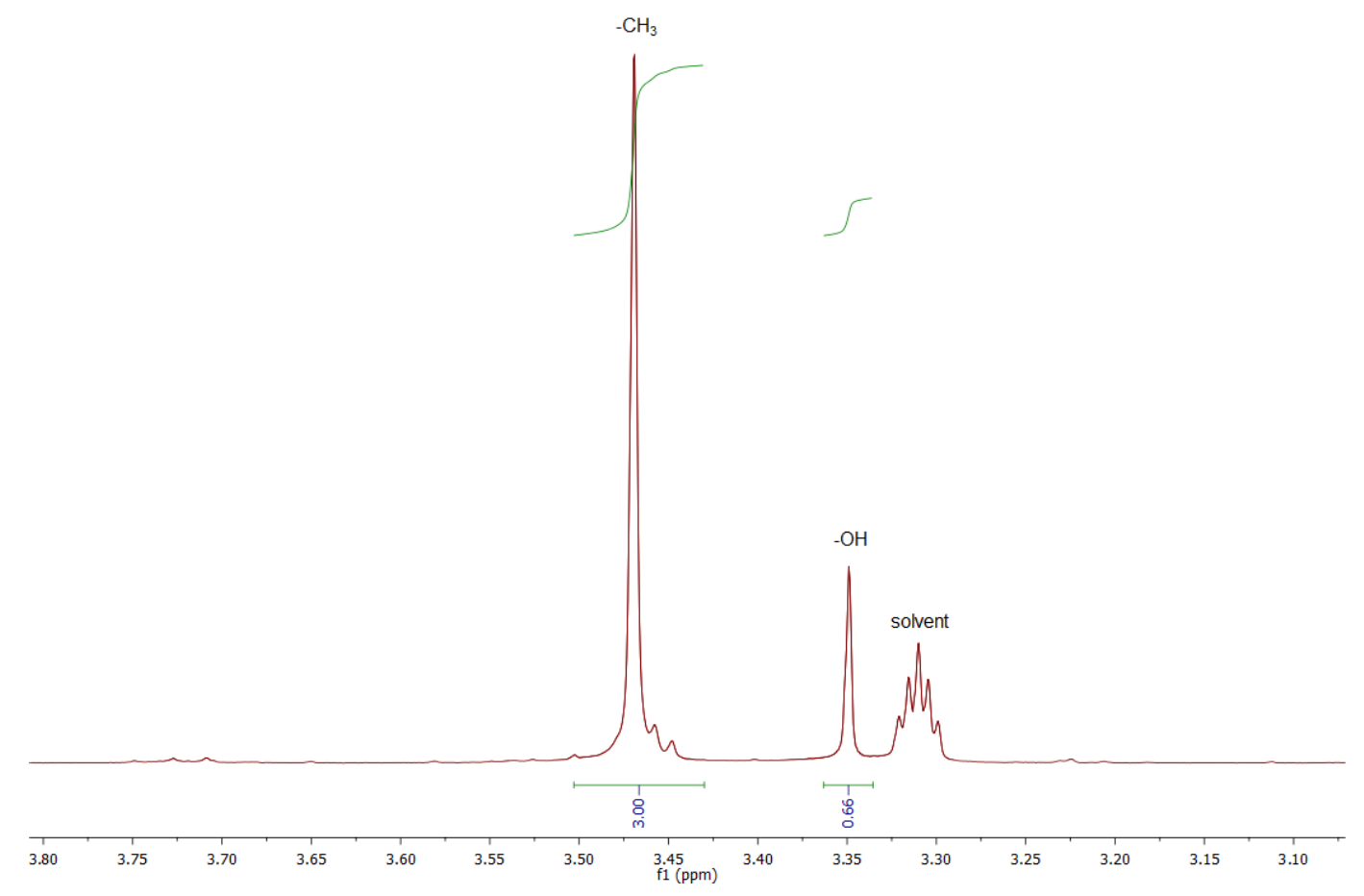

Figure 2.38. ${ }^{1} \mathrm{H}$ NMR spectrum of complex $\mathbf{1 0}$ in methanol- $d_{4}$ : the integration is different from 3:1 due to the H/D exchange on the methanol ligands. 

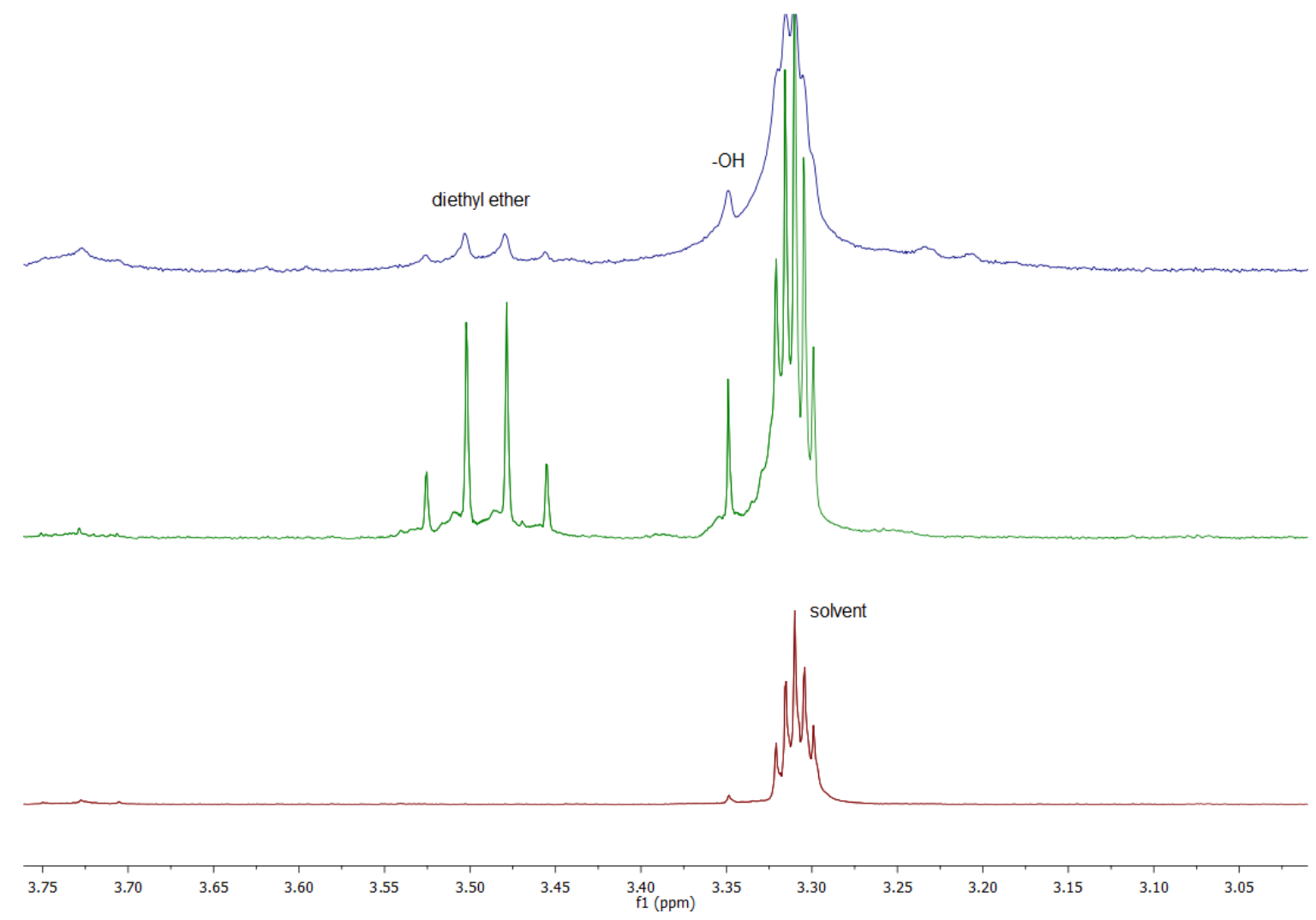

Figure 2.39. ${ }^{1}$ H NMR spectra of complex 10- $d_{8}$ : before (bottom) and after H/D exchange with protio methanol (middle) and ethanol (top).

Because complex $\mathbf{1 0}$ cannot be isolated as a solid, in situ deprotonation in methanol was attempted (Scheme 2.20). However, in situ deprotonation of complex 10 did not yield stable products after the addition of base. Decomposition was observed even at low temperatures (

Table 2.2). Deprotonation in other solvents cannot be tested because of the decomposition of complex $\mathbf{1 0}$. 


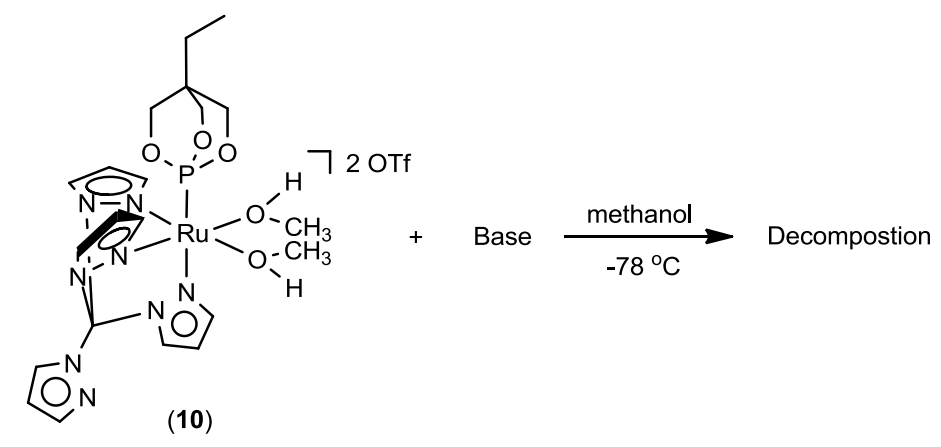

Scheme 2.20. In situ deprotonation of complex $\mathbf{1 0}$ results in decomposition.

Table 2.2. Results of the deprotonation of complex $\mathbf{1 0}$ in methanol by different bases.

\begin{tabular}{c|ccc}
\hline & $2,6-$ Lutidine & $\mathrm{NaOMe}$ & $\mathrm{CsOH}$ \\
\hline $\mathrm{p} K_{\mathrm{a}}{ }^{*}$ & $6.6^{106}$ & $15.5^{107}$ & 15.7 \\
\hline Results & decomposition & decomposition & decomposition \\
\hline
\end{tabular}

*Values of conjugate acids in water. 


\subsubsection{Attempts to synthesize a Ru(II)-hydroxide complex}

Among the reported late metal-heteroatomic complexes that are capable of the metalmediated $\mathrm{C}-\mathrm{H}$ activation, there are three major types of bound heteroatomic ligands: amido, alkoxide/aryloxide and hydroxide. ${ }^{67-70,72,95,108-110}$ In addition to attempts to synthesize $\mathrm{Ru}(\mathrm{II})$-anilido and -methoxide complexes, a $\mathrm{Ru}(\mathrm{II})$-hydroxide complex supported by $\mathrm{C}(\mathrm{pz})_{4}$ is a synthetic target. Our group has detailed the synthesis and reactivity of neutral TpRu(II) hydroxide complexes. ${ }^{63,67,68}$ Among the reported synthetic strategies, transition metal hydroxide complexes can be synthesized from reaction of metal-halide with hydroxide base (e.g., $\mathrm{CsOH}$ ) or by deprotonation of metal-aqua complexes. $^{108-114}$

The direct synthesis of a $\mathrm{Ru}(\mathrm{II})$-hydroxide complex by reaction of dimeric complex 4 and $\mathrm{CsOH}$ was not successful (Scheme 2.21). Limited by the solubility of $\mathbf{4}$ and $\mathrm{CsOH}$, methanol was selected as solvent. Only decomposition products were observed by ${ }^{1} \mathrm{H}$ NMR spectroscopy.

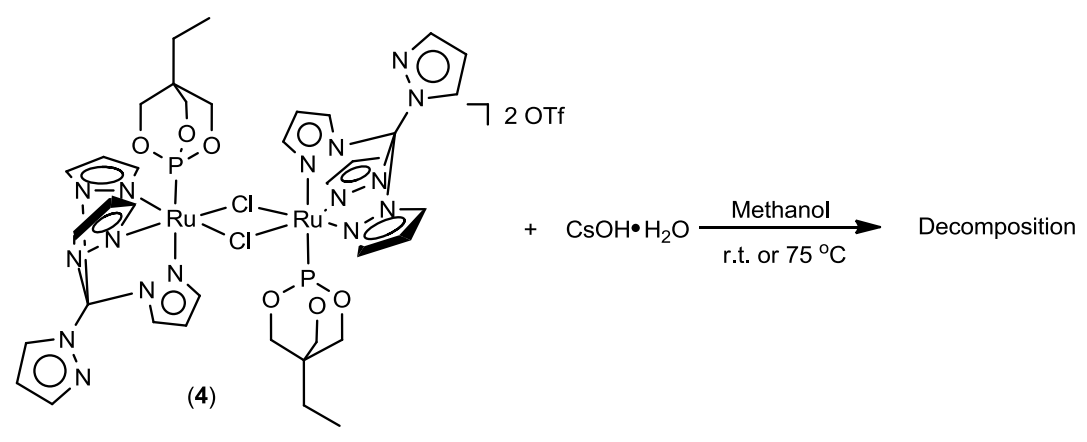

Scheme 2.21. Direct synthesis of Ru(II)-hydroxide complex was not successful due to decomposition.

As mentioned above, another synthetic strategy to synthesize a $\mathrm{Ru}(\mathrm{II})$ hydroxide complex is deprotonation of $\mathrm{Ru}(\mathrm{II})$-aqua complex. The complex can be prepared by 
reaction of 4 with excess water in tetrahydrofuran or acetone, yielding mono-aqua complex 11 (Scheme 2.22). Dimer 4 is not soluble in THF without the addition of water as a co-solvent. Careful adjustment of the amount of water in the reaction mixture revealed that at least twenty equivalents of water are needed for the reaction to proceed completely and cleanly.

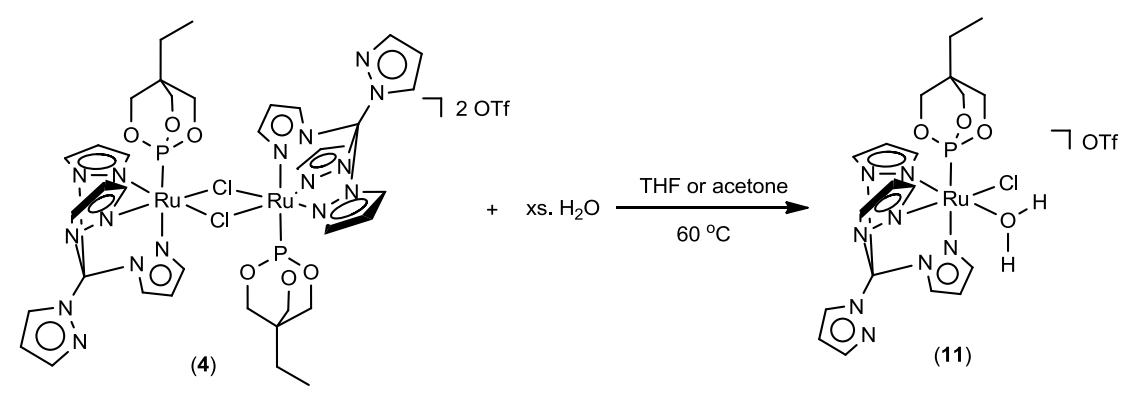

Scheme 2.22. Synthesis of $\left\{\left[\kappa^{3}-\mathrm{C}(\mathrm{pz})_{4}\right] \mathrm{Ru}\left[\mathrm{P}\left(\mathrm{OCH}_{2}\right)_{3} \mathrm{CEt}\right](\mathrm{Cl})\left(\mathrm{H}_{2} \mathrm{O}\right)\right\}\{\mathrm{OTf}\}(\mathbf{1 1})$.

Monitoring the reaction of $\mathbf{4}$ and water by ${ }^{1} \mathrm{H}$ NMR spectroscopy reveals twelve resonances for $\mathrm{C}(\mathrm{pz})_{4}$ ligand (Figure 2.40 and Figure 2.41), indicating in situ generation of $\mathbf{1 1}$ and loss of $\mathrm{C}_{\mathrm{s}}$ molecular symmetry. This is consistent with the structure of complex $\mathbf{1 1}$ indicated in Scheme 2.22. Isolation of $\mathbf{1 1}$ was not successful due to its low stability. Decomposition took place after the removal of solvent and water. Complex 11 decomposed even faster in other solvents. This is most likely because that the labile aqua ligands can be stabilized by interactions with water (e.g., hydrogen bond) and this stabilization effect is no longer present once water is removed. 


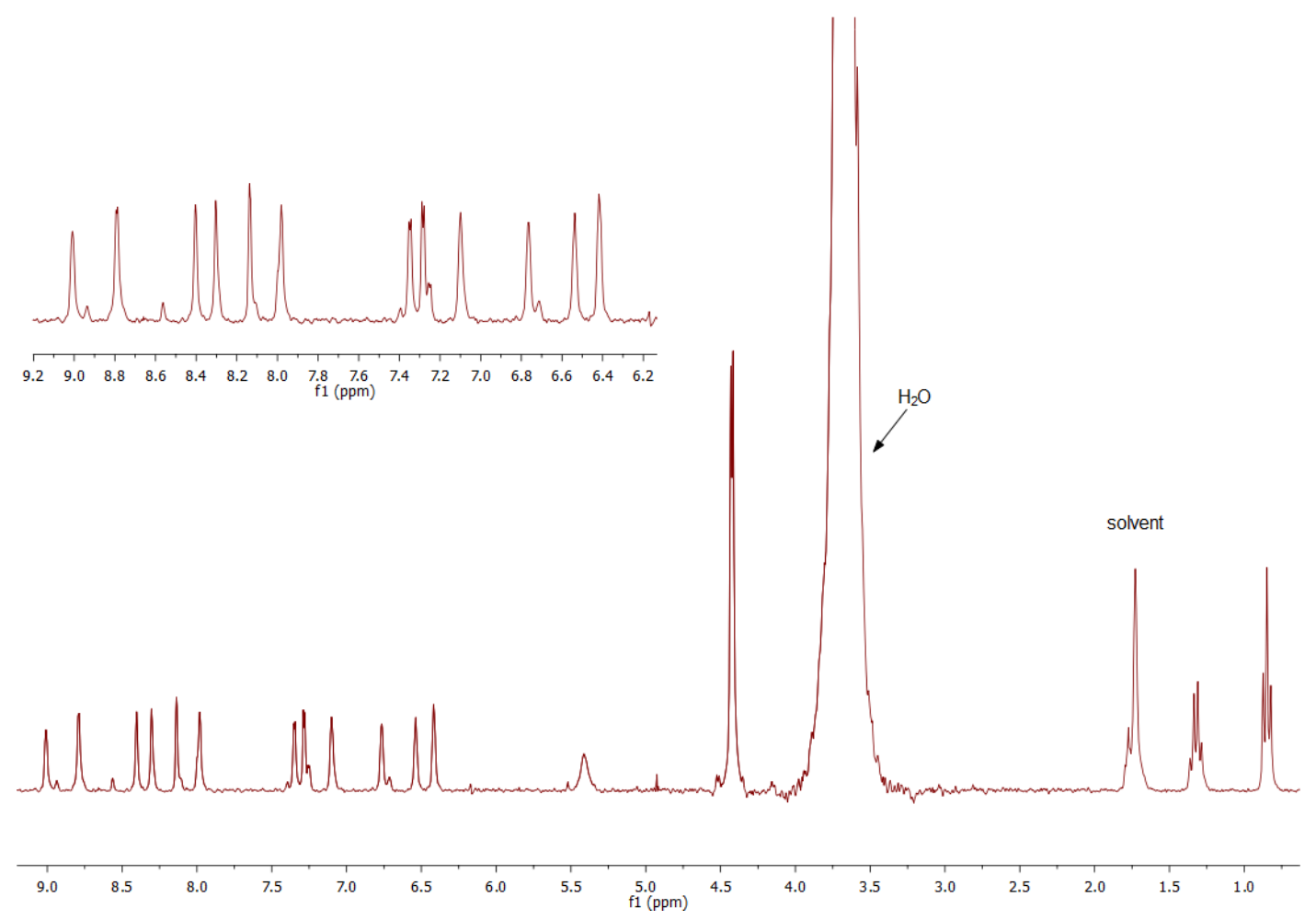

Figure 2.40. ${ }^{1} \mathrm{H}$ NMR spectrum of in-situ generation of complex 11 in THF- $d_{8}$.

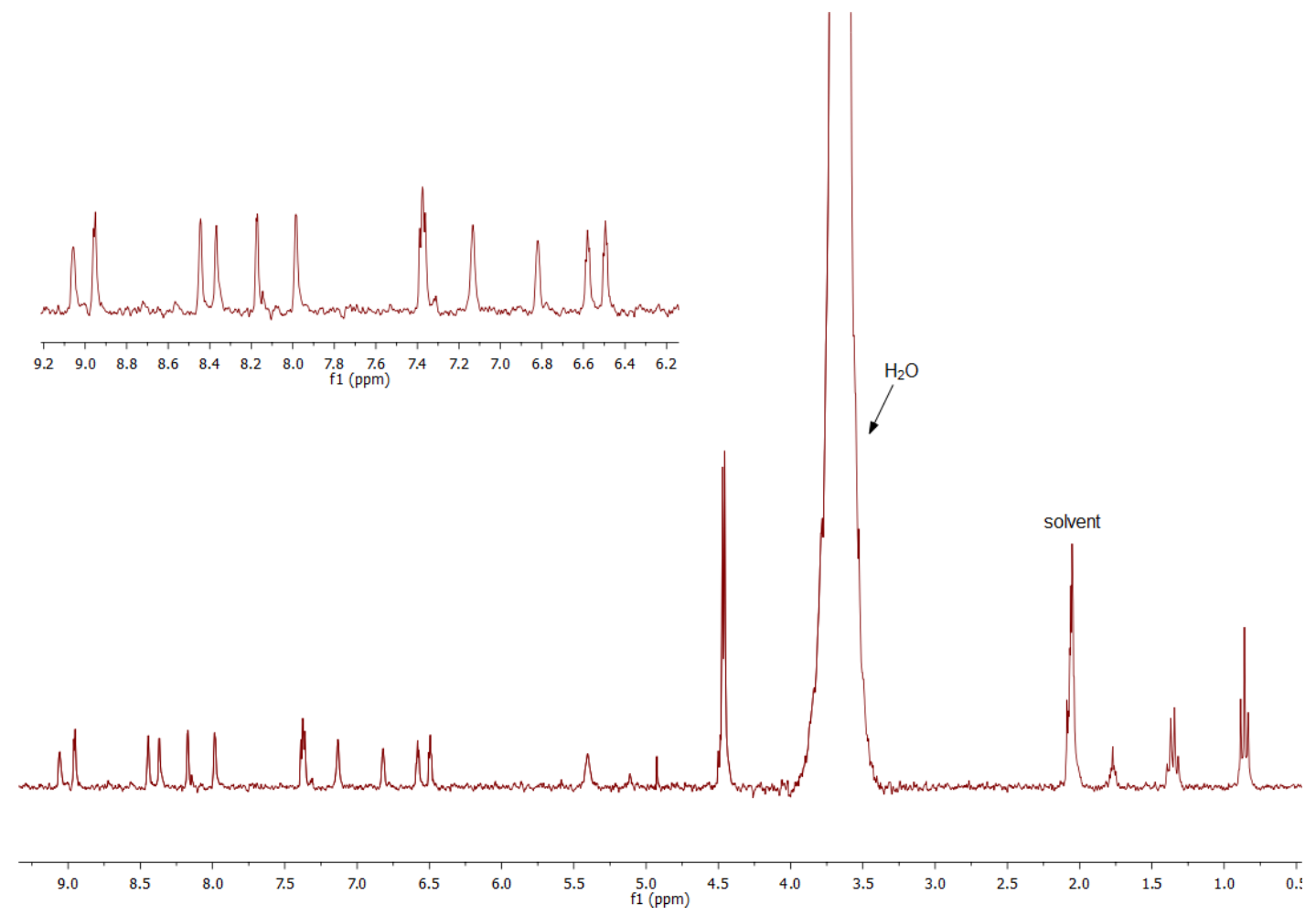

Figure 2.41. ${ }^{1} \mathrm{H}$ NMR spectrum of in-situ generation of complex 11 in acetone- $d_{6}$. 
Because the isolation of complex 11 was unsuccessful, in situ deprotonations were attempted (Scheme 2.23). However, the deprotonation reactions did not produce stable or isolable products. Only decomposition products were observed by ${ }^{1} \mathrm{H}$ NMR spectroscopy (Table 2.3). Deprotonation at low temperatures was not conducted because of the presence of water.

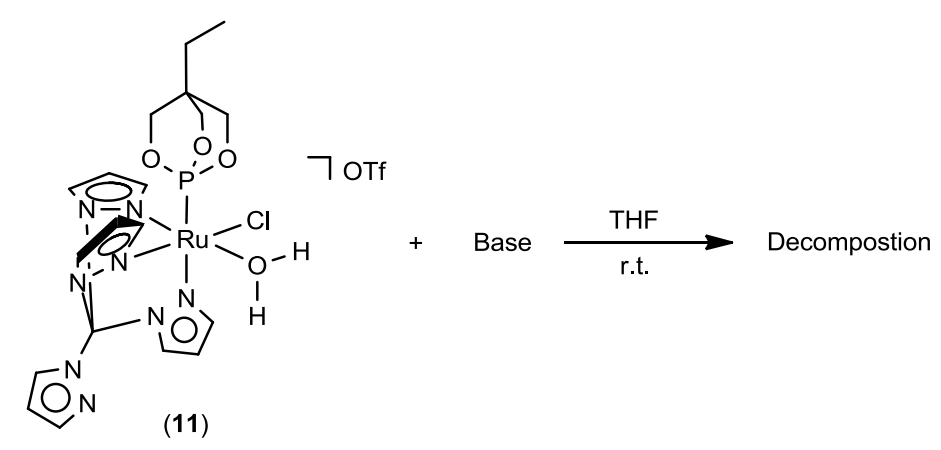

Scheme 2.23. In situ deprotonation of complex 11 results in decomposition.

Table 2.3. Results of deprotonation of complex 11 in different solvent/base pairs.

\begin{tabular}{c|cccccc}
\hline Solvent & $\mathrm{NaOH}$ & $\mathrm{CsOH}$ & $\mathrm{NaOMe}$ & 2,6-Lutidine & Pyridine & $\mathrm{NEt}_{3}$ \\
\hline THF & Decomp. & Decomp. & Decomp. & Decomp. & Decomp. & Decomp. \\
\hline
\end{tabular}




\subsection{Conclusions}

While the $\mathrm{Ru}(\mathrm{II})-\mathrm{XH}(\mathrm{X}=\mathrm{NHPh}, \mathrm{OMe}, \mathrm{OH})$ type of complexes supported by tetra(pyrazolyl)methane can be synthesized, only the complexes bearing aniline ligands can be isolated as solids. The $\mathrm{Ru}-$ methanol complex $\mathbf{1 0}$ is stable in methanol but cannot be isolated. The Ru-aqua complex $\mathbf{1 1}$ is stable in THF or acetone in the presence of water. It decomposes when the solution is concentrated and decomposes rapidly if dissolved in other organic solvents.

Attempts to synthesize isolable $\mathrm{Ru}(\mathrm{II})-\mathrm{X}$ type complexes by deprotonation of $\mathrm{Ru}(\mathrm{II})-$ $\mathrm{XH}$ all failed. When $\mathrm{X}=\mathrm{NHPh}$, the anilido ligand of $\mathrm{Ru}-\mathrm{X}$ complex was observed by VT NMR spectroscopy. However, isolation of $\mathrm{Ru}$-anilido complexes failed due to the decomposition. Deprotonations of $\mathrm{Ru}-$ methanol or -aqua complexes were not successful due to the instantaneous decomposition of the complexes upon addition of base. The exact reasons for the highly unstable $\mathrm{Ru}-\mathrm{X}$ complexes remain unclear. Further attempts to synthesize $\mathrm{Ru}(\mathrm{II})-\mathrm{X}$ complexes supported by tetra(pyrazolyl)methane could focus on adjustment of the electronic and steric profiles of the complex through a survey of ligands that engender suitable reactivity and promote stability of $\mathrm{Ru}-\mathrm{X}$ complexes. 


\subsection{Experimental}

General Methods. Unless otherwise noted, all synthetic procedures were performed under anaerobic conditions in a nitrogen-filled glovebox or by using standard Schlenk techniques. Glovebox purity was maintained by periodic nitrogen purges and was monitored by an oxygen analyzer $\left[\mathrm{O}_{2}(\mathrm{~g})<15 \mathrm{ppm}\right.$ for all reactions]. Tetrahydrofuran was dried by distillation from sodium/benzophenone. Toluene was distilled over sodium. Hexanes and pentane were distilled over $\mathrm{P}_{2} \mathrm{O}_{5}$. Diethyl ether, methanol, aniline were dried by distillation from $\mathrm{CaH}_{2}$. Methylene chloride was purified by passage through a column of activated alumina. Deuterated NMR solvents were degassed by three freezepump-thaw cycles and stored over $4 \AA$ A molecular sieves. ${ }^{1} \mathrm{H}$ NMR spectra were recorded on a Varian Mercury $300 \mathrm{MHz}$ spectrometer, and ${ }^{13} \mathrm{C}$ NMR spectra were recorded on a Varian Mercury $300 \mathrm{MHz}$ spectrometer (operating frequency $75 \mathrm{MHz}$ ). All ${ }^{1} \mathrm{H}$ and ${ }^{13} \mathrm{C}$ NMR spectra were referenced against tetramethylsilane using resonances due to the residual proton signals in the deuterated solvents or the ${ }^{13} \mathrm{C}$ resonances of the deuterated solvents. ${ }^{31} \mathrm{P}$ NMR spectra were obtained on a Varian Mercury $300 \mathrm{MHz}$ spectrometer (operating frequency $121 \mathrm{MHz}$ ) and referenced against an external standard of 85\% $\mathrm{H}_{3} \mathrm{PO}_{4}(\delta=0) .{ }^{19} \mathrm{~F}$ NMR spectra were obtained on a Varian Mercury $300 \mathrm{MHz}$ spectrometer (operating frequency $282 \mathrm{MHz}$ ) and referenced against an external standard of $\mathrm{C}_{6} \mathrm{~F}_{6}(\delta=-164.9)$. All variable-temperature NMR experiments were performed on a Varian Mercury $300 \mathrm{MHz}$ spectrometer. All other NMR spectra were acquired at room temperature. Electrochemical experiments were performed under a nitrogen atmosphere using a BAS Epsilon Potentiostat. Cyclic voltammograms were recorded in acetonitrile using a standard three-electrode cell from $-1700 \mathrm{mV}$ to $1700 \mathrm{mV}$ at $100 \mathrm{mV} / \mathrm{s}$ with a 
glassy carbon working electrode and tetrabutylammonium hexafluorophosphate as electrolyte. Tetrabutylammonium hexafluorophosphate was dried under dynamic vacuum at $110{ }^{\circ} \mathrm{C}$ for $48 \mathrm{~h}$ prior to use. All potentials are reported versus NHE (normal hydrogen electrode) using ferrocene or cobaltocenium hexafluorophosphate as the internal standard. Elemental analyses were performed by Atlantic Microlabs, Inc. $\mathrm{P}\left(\mathrm{OCH}_{2}\right)_{3} \mathrm{CEt}$ was obtained from a commercial source and purified by dissolving in hexanes followed by filtration through Celite. The filtrate was concentrated to dryness to yield pure material. $\mathrm{RuCl}_{2}\left(\mathrm{PPh}_{3}\right)_{3}$ and $\mathrm{NaBAr}_{4}{ }_{4}$ were prepared according to published procedures. ${ }^{115-117}$ Unless otherwise noted, all other reagents were used as purchased from commercial sources.

$\mathbf{C}(\mathbf{p z})_{4}$ (1). A mixture of pyrazole $(8.023 \mathrm{~g}, 117.6 \mathrm{mmol}), \mathrm{KOH}(38.7 \mathrm{~g}, 588 \mathrm{mmol})$, $\mathrm{K}_{2} \mathrm{CO}_{3}(16.21 \mathrm{~g}, 117.6 \mathrm{mmol})$, and $\mathrm{Bu}_{4} \mathrm{~N} \cdot \mathrm{HSO}_{4}(2.1 \mathrm{~g}, 5.8 \mathrm{mmol})$ was refluxed in $~ 100$ $\mathrm{mL}$ of $\mathrm{CCl}_{4}$ for $18 \mathrm{~h}$. The mixture was cooled to room temperature and filtered through Celite. The filtrate was collected and filtered again through a 2-inch-thick silica gel column using $1 \mathrm{~L}$ of methylene chloride as eluant. The pale yellow filtrate was concentrated under a reduced pressure. To the orange-red residual was added three portions of $3 \mathrm{~mL}$ of cold diethyl ether. The resulting white solid was isolated and dried in vacuo $(345 \mathrm{mg}, 4 \%) .{ }^{1} \mathrm{H} \mathrm{NMR}\left(\mathrm{CDCl}_{3}, \delta\right): 7.70\left(4 \mathrm{H}, \mathrm{d},{ }^{3} J_{\mathrm{HH}}=2 \mathrm{~Hz}\right.$, pz 3 or 5 position), $7.58\left(4 \mathrm{H}, \mathrm{d},{ }^{3} J_{\mathrm{HH}}=3 \mathrm{~Hz}, \mathrm{pz} 3\right.$ or 5 position), $6.41\left(4 \mathrm{H}, \mathrm{dd},{ }^{3} J_{\mathrm{HH}}=3 \mathrm{~Hz},{ }^{3} J_{\mathrm{HH}}=2 \mathrm{~Hz}, \mathrm{pz} 4\right.$ position).

$\left[\boldsymbol{\kappa}^{3}-\mathbf{C}(\mathbf{p z})_{4}\right] \mathbf{R u C l}_{\mathbf{2}}\left(\mathbf{P P h}_{3}\right)$ (2). A mixture of $\mathbf{1}(433 \mathrm{mg}, 1.54 \mathrm{mmol})$ and $\mathrm{RuCl}_{2}\left(\mathrm{PPh}_{3}\right)_{3}$ $(1.61 \mathrm{~g}, 1.68 \mathrm{mmol})$ was refluxed in $\sim 10 \mathrm{~mL}$ of toluene for $18 \mathrm{~h}$. The mixture was subsequently cooled to room temperature and filtered through a fine porosity frit. The 
dark green solid was washed with toluene and pentane and then dried in vacuo $(960 \mathrm{mg}$, 87.1\%). ${ }^{1} \mathrm{H}$ NMR $\left(\mathrm{CDCl}_{3}, \delta\right): 8.72\left(1 \mathrm{H}, \mathrm{d},{ }^{3} J_{\mathrm{HH}}=2 \mathrm{~Hz}, \mathrm{pz} 3\right.$ or 5 position $), 8.63(1 \mathrm{H}, \mathrm{d}$, ${ }^{3} J_{\mathrm{HH}}=3 \mathrm{~Hz}, \mathrm{pz} 3$ or 5 position), $8.27\left(1 \mathrm{H}, \mathrm{d},{ }^{3} J_{\mathrm{HH}}=3 \mathrm{~Hz}, \mathrm{pz} 3\right.$ or 5 position), $8.15(1 \mathrm{H}, \mathrm{d}$, ${ }^{3} J_{H H}=2 \mathrm{~Hz}, \mathrm{pz} 3$ or 5 position), 7.82, $7.25\left(15 \mathrm{H}\right.$ total, each a m, $\left.\mathrm{PPh}_{3}\right), 6.95(1 \mathrm{H}, \mathrm{m}, \mathrm{pz} 4$ position), $6.85\left(2 \mathrm{H}, \mathrm{d},{ }^{3} J_{\mathrm{HH}}=3 \mathrm{~Hz}\right.$, coordinated pz 3 or 5 position) $6.74\left(2 \mathrm{H}, \mathrm{d},{ }^{3} J_{\mathrm{HH}}=2\right.$ $\mathrm{Hz}$, coordinated pz 3 or 5 position), $6.53(1 \mathrm{H}, \mathrm{m}, \mathrm{pz} 4$ position), 5.91 (2H, t, coordinated pz 4 position). ${ }^{13} \mathrm{C}\left\{{ }^{1} \mathrm{H}\right\}$ NMR $\left(\mathrm{CDCl}_{3}, \delta\right): 151.3,148.2,144.7,136.2,134.4,133.5$ (each a s, pz 3 or 5 position), 135.2 (d, ${ }^{1} J_{\mathrm{PC}}=9 \mathrm{~Hz}$, phenyl ipso), 132.6, 129.4 (each a s, phenyl meta and para), $127.8\left(\mathrm{~d},{ }^{2} J_{\mathrm{PC}}=9 \mathrm{~Hz}\right.$, phenyl ortho), 111.6, 109.6, 109.4 (each a s, pz 4 position), 94.4 (s, $\left.C(\mathrm{pz})_{4}\right) .{ }^{31} \mathrm{P}\left\{{ }^{1} \mathrm{H}\right\} \mathrm{NMR}\left(\mathrm{CDCl}_{3}, \delta\right): 51.9$ (s, $\left.P \mathrm{Ph}_{3}\right)$. Attempts to obtain favorable elemental analysis results are not successful.

$\left[\boldsymbol{\kappa}^{\mathbf{3}}-\mathbf{C}(\mathbf{p z})_{4}\right] \mathbf{R u C l}_{2}\left[\mathbf{P}(\mathbf{O C H})_{3} \mathbf{C E t}\right]$ (3). A mixture of $\mathbf{2}(840 \mathrm{mg}, 1.17 \mathrm{mmol})$ and $\mathrm{P}\left(\mathrm{OCH}_{2}\right)_{3} \mathrm{CEt}(953 \mathrm{mg}, 5.90 \mathrm{mmol})$ was refluxed in $\sim 25 \mathrm{~mL}$ of chloroform for $18 \mathrm{~h}$. The mixture, which contained a dark green precipitate, was concentrated under reduced pressure to approximately $5 \mathrm{~mL}$. Pentane $(20 \mathrm{~mL})$ was slowly added to yield more dark green precipitate. The resulting solid was collected on a fine porosity frit and washed with pentane. The solid was refluxed in $25 \mathrm{~mL}$ of chloroform for $18 \mathrm{~h}$. The mixture was cooled to room temperature and filtered through a fine frit. The collected green solid was washed with pentane and dried in vacuo to yield yellow solid (502 mg, 70.2\%). ${ }^{1} \mathrm{H}$ NMR $\left(\mathrm{CD}_{2} \mathrm{Cl}_{2}, \delta\right): 8.65(1 \mathrm{H}, \mathrm{bs}, \mathrm{pz} 3$ or 5 position), 8.54 (1H, bs, pz 3 or 5 position), $8.31(1 \mathrm{H}$, $\mathrm{d},{ }^{3} J_{\mathrm{HH}}=3 \mathrm{~Hz}, \mathrm{pz} 3$ or 5 position $), 8.20\left(1 \mathrm{H}, \mathrm{d},{ }^{3} J_{\mathrm{HH}}=2 \mathrm{~Hz}, \mathrm{pz} 3\right.$ or 5 position), $8.12(2 \mathrm{H}$, $\mathrm{d},{ }^{3} J_{\mathrm{HH}}=2 \mathrm{~Hz}$, coordinated pz 3 or 5 position $), 7.05\left(2 \mathrm{H}, \mathrm{d},{ }^{3} J_{\mathrm{HH}}=7 \mathrm{~Hz}\right.$, coordinated pz 3 or 5 position), $6.95\left(1 \mathrm{H}, \mathrm{dd},{ }^{3} J_{\mathrm{HH}}=3 \mathrm{~Hz}, \mathrm{pz} 4\right.$ position), $6.62(1 \mathrm{H}, \mathrm{m}, \mathrm{pz} 4$ position), 6.33 
$\left(2 \mathrm{H}, \mathrm{dd},{ }^{3} J_{\mathrm{HH}}=2 \mathrm{~Hz}\right.$, coordinated pz 4 position $), 4.38\left(6 \mathrm{H}, \mathrm{d},{ }^{3} J_{\mathrm{PH}}=4.4 \mathrm{~Hz},-\left(\mathrm{OCH}_{2}\right)_{3},\right)$, $1.27\left(2 \mathrm{H}, \mathrm{q},{ }^{3} J_{\mathrm{HH}}=8 \mathrm{~Hz},-\mathrm{CH}_{2} \mathrm{CH}_{3}\right), 0.86\left(3 \mathrm{H}, \mathrm{t},{ }^{3} J_{\mathrm{HH}}=8 \mathrm{~Hz},-\mathrm{CH}_{2} \mathrm{CH}_{3}\right) .{ }^{13} \mathrm{C}\left\{{ }^{1} \mathrm{H}\right\} \mathrm{NMR}$ $\left(\mathrm{CD}_{3} \mathrm{NO}_{2}, \delta\right): 151.2,147.7,145.6,137.3,134.4,133.6$ (each a s, pz 3 or 5 position), 111.8, 108.8, 108.5 (each a s, pz 4 position), $94.4\left(\mathrm{~s}, C(\mathrm{pz})_{4}\right), 74.4\left(\mathrm{~d},{ }^{2} J_{\mathrm{PC}}=7 \mathrm{~Hz},-\left(\mathrm{OCH}_{2}\right)_{3}\right)$, $35.3\left(\mathrm{~d},{ }^{3} J_{\mathrm{PC}}=31 \mathrm{~Hz},-\left(\mathrm{OCH}_{2}\right)_{3} \mathrm{C}-\right), 23.1\left(\mathrm{~s},-\mathrm{CH}_{2} \mathrm{CH}_{3}\right), 6.3\left(\mathrm{~s},-\mathrm{CH}_{2} \mathrm{CH}_{3}\right) .{ }^{31} \mathrm{P}\left\{{ }^{1} \mathrm{H}\right\}$ $\operatorname{NMR}\left(\mathrm{CD}_{2} \mathrm{Cl}_{2}, \delta\right): 127.5\left(\mathrm{~s}, P\left(\mathrm{OCH}_{2}\right)_{3} \mathrm{C}-\right) . \mathrm{CV}\left(\mathrm{CH}_{3} \mathrm{CN}, \mathrm{TBAH}, 100 \mathrm{mV} / \mathrm{s}\right): E_{1 / 2}=0.71$ $\mathrm{V}\{\mathrm{Ru}(\mathrm{III} / \mathrm{II})\}$. Attempts to obtain favorable elemental analysis results are not successful.

$\left\{\left[\boldsymbol{\kappa}^{3}-\mathbf{C}(\mathbf{p z})_{4}\right] \mathbf{R u C l}\left[\mathbf{P}(\mathbf{O C H})_{3} \mathbf{C E t}\right]\right\}_{2}\{\mathrm{OTf}\}_{\mathbf{2}}$ (4). A mixture of 3 (639 mg, $\left.1.04 \mathrm{mmol}\right)$ and TlOTf (368 mg, $1.04 \mathrm{mmol}$ ) was stirred in $\sim 50 \mathrm{~mL}$ of methylene chloride at room temperature. After $4 \mathrm{~h}$, the mixture was filtered through Celite. The orange filtrate was concentrated to dryness under reduced pressure. The sticky residue was reconstituted in $\sim 30 \mathrm{~mL}$ of $\mathrm{THF}$ and refluxed for $3 \mathrm{~h}$. A yellow precipitate formed. The mixture was then allowed to cool to room temperature, and the precipitate was collected on a fine porosity frit. The yellow solid was washed with THF and pentane and then in vacuo (684 mg, $90.2 \%) .{ }^{1} \mathrm{H}$ NMR $\left(\mathrm{CD}_{2} \mathrm{Cl}_{2}, \delta\right): 8.86(1 \mathrm{H}, \mathrm{bs}, \mathrm{pz} 3$ or 5 position), $8.62(1 \mathrm{H}, \mathrm{bs}, \mathrm{pz} 3$ or 5 position), $8.36\left(1 \mathrm{H}, \mathrm{d},{ }^{3} J_{\mathrm{HH}}=3 \mathrm{~Hz}, \mathrm{pz} 3\right.$ or 5 position $), 8.23\left(1 \mathrm{H}, \mathrm{d},{ }^{3} J_{\mathrm{HH}}=1 \mathrm{~Hz}, \mathrm{pz} 3\right.$ or 5 position), $7.99\left(2 \mathrm{H}, \mathrm{d},{ }^{3} J_{\mathrm{HH}}=2 \mathrm{~Hz}\right.$, pz 3 or 5 position $), 7.10\left(2 \mathrm{H}, \mathrm{d},{ }^{3} J_{\mathrm{HH}}=3 \mathrm{~Hz}\right.$, coordinated pz 3 or 5 position), $7.02\left(1 \mathrm{H}, \mathrm{dd},{ }^{3} J_{\mathrm{HH}}=2 \mathrm{~Hz}, \mathrm{pz} 4\right.$ position), 6.39 (2H, dd, ${ }^{3} J_{\mathrm{HH}}=2 \mathrm{~Hz}$, coordinated pz 4 position), $6.73(1 \mathrm{H}, \mathrm{m}, \mathrm{pz} 4$ position $), 4.52\left(6 \mathrm{H}, \mathrm{d},{ }^{3} J_{\mathrm{PH}}=5\right.$ $\left.\mathrm{Hz},-\left(\mathrm{OCH}_{2}\right)_{3}\right), 1.36\left(2 \mathrm{H}, \mathrm{q},{ }^{3} J_{\mathrm{HH}}=8 \mathrm{~Hz},-\mathrm{CH}_{2} \mathrm{CH}_{3},\right), 0.90\left(3 \mathrm{H}, \mathrm{t},{ }^{3} J_{\mathrm{HH}}=8 \mathrm{~Hz},-\right.$ $\left.\mathrm{CH}_{2} \mathrm{CH}_{3}\right) .{ }^{13} \mathrm{C}\left\{{ }^{1} \mathrm{H}\right\} \mathrm{NMR}\left(\mathrm{CD}_{2} \mathrm{Cl}_{2}, \delta\right): 151.2,147.7,145.8,136.9,134.7,133.7$ (each a s, pz 3 or 5 position), 112.5, 109.5, 109.3 (each a s, pz 4 position), $75.2\left(\mathrm{~s},-\left(\mathrm{OCH}_{2}\right)_{3}\right), 35.9$ $\left(\mathrm{d},{ }^{3} J_{\mathrm{PC}}=32 \mathrm{~Hz},-\left(\mathrm{OCH}_{2}\right)_{3} \mathrm{C}-\right), 23.6\left(\mathrm{~s},-\mathrm{CH}_{2} \mathrm{CH}_{3}\right), 7.2\left(\mathrm{~s},-\mathrm{CH}_{2} C \mathrm{H}_{3}\right) .{ }^{31} \mathrm{P}\left\{{ }^{1} \mathrm{H}\right\} \mathrm{NMR}$ 
$\left(\mathrm{CD}_{2} \mathrm{Cl}_{2}, \delta\right): 128.6\left(\mathrm{~s}, P\left(\mathrm{OCH}_{2}\right)_{3} \mathrm{C}-\right) .{ }^{19} \mathrm{~F} \mathrm{NMR}\left(\mathrm{CD}_{2} \mathrm{Cl}_{2}, \delta\right):-77.5$ (s, OTf). Attempts to obtain elemental analysis results are not successful.

$\left\{\left[\boldsymbol{\kappa}^{3}-\mathbf{C}(\mathbf{p z})_{4}\right] \mathbf{R u}\left[\mathbf{P}(\mathbf{O C H})_{3} \mathbf{C E t}\right](\mathbf{C l})\left(\mathbf{N H}_{2} \mathbf{P h}\right)\right\}\{$ OTf $\}$ (5). A mixture of 4 (651 mg, $0.451 \mathrm{mmol})$ and aniline $(0.3 \mathrm{~mL}, 3 \mathrm{mmol})$ was heated in $\sim 10 \mathrm{~mL}$ of $\mathrm{THF}$ at $90{ }^{\circ} \mathrm{C}$ in a glass pressure tube. After 3 days, the mixture was cooled to room temperature and filtered through Celite. The filtrate was concentrated under reduced pressure to $\sim 3 \mathrm{~mL}$. Pentane $(20 \mathrm{~mL})$ was slowly added to yield a precipitate. The resulting yellow precipitate was washed with pentane and dried in vacuo (543 mg, 74.3\%). ${ }^{1} \mathrm{H} \mathrm{NMR}\left(\mathrm{CD}_{2} \mathrm{Cl}_{2}, \delta\right)$ : $8.63,8.42,8.21,8.15,8.10,7.94,7.68,7.00$ (each $\mathrm{H}$, each a d, ${ }^{3} J_{\mathrm{HH}}=2 \sim 3 \mathrm{~Hz}$, pz 3 or 5 position), $7.06\left(3 \mathrm{H}, \mathrm{m}\right.$, phenyl meta and para), $6.81\left(2 \mathrm{H}, \mathrm{d},{ }^{3} J_{\mathrm{HH}}=7 \mathrm{~Hz}\right.$, phenyl ortho), $6.52,6.40,6.22,6.02\left(\right.$ each $1 \mathrm{H}$, each a d, ${ }^{3} J_{\mathrm{HH}}=2 \mathrm{~Hz}, \mathrm{pz} 4$ position $), 5.72\left(1 \mathrm{H}, \mathrm{d},{ }^{2} J_{\mathrm{HH}}=\right.$ $\left.12 \mathrm{~Hz}, \mathrm{PhNH}_{2}\right), 4.76\left(1 \mathrm{H}, \mathrm{d},{ }^{2} J_{\mathrm{HH}}=12 \mathrm{~Hz}, \mathrm{PhNH} H_{2}\right), 4.47\left(6 \mathrm{H}, \mathrm{d},{ }^{3} J_{\mathrm{PH}}=5 \mathrm{~Hz},-\left(\mathrm{OCH}_{2}\right)_{3}\right)$, $1.32\left(2 \mathrm{H}, \mathrm{q},{ }^{3} J_{\mathrm{HH}}=8 \mathrm{~Hz},-\mathrm{CH}_{2} \mathrm{CH}_{3},\right), 0.90\left(3 \mathrm{H}, \mathrm{t},{ }^{3} J_{\mathrm{HH}}=8 \mathrm{~Hz},-\mathrm{CH}_{2} \mathrm{CH}_{3}\right) .{ }^{13} \mathrm{C}\left\{{ }^{1} \mathrm{H}\right\}$ $\operatorname{NMR}\left(\mathrm{CD}_{2} \mathrm{Cl}_{2}, \delta\right): 151.9,150.9,148.0,145.9,143.7,137.2,135.2,134.9$ (each a s, pz 3 or 5 position), 133.8 (s, phenyl ipso), 129.4, 125.3, 121.4 (each a s, phenyl ortho, meta, and para), 112.6, 109.7, 109.5, 109.0 (each a s, pz 4 position), 94.2 (s, $\left.C(\mathrm{pz})_{4}\right), 75.2$ (s, $\left.\left(\mathrm{OCH}_{2}\right)_{3}\right), 35.7\left(\mathrm{~d},{ }^{3} J_{\mathrm{PC}}=32 \mathrm{~Hz},-\left(\mathrm{OCH}_{2}\right)_{3} \mathrm{C}-\right), 23.7\left(\mathrm{~s},-\mathrm{CH}_{2} \mathrm{CH}_{3}\right), 7.4\left(\mathrm{~s},-\mathrm{CH}_{2} \mathrm{CH}_{3}\right)$. ${ }^{31} \mathrm{P}\left\{{ }^{1} \mathrm{H}\right\}$ NMR $\left(\mathrm{CD}_{2} \mathrm{Cl}_{2}, \delta\right): 129.6\left(\mathrm{~s}, P\left(\mathrm{OCH}_{2}\right){ }_{3} \mathrm{C}-\right) .{ }^{19} \mathrm{~F}$ NMR $\left(\mathrm{CDCl}_{3}, \delta\right):-79.5$ (s, OTf). $\mathrm{CV}\left(\mathrm{CH}_{3} \mathrm{CN}, \mathrm{TBAH}, 100 \mathrm{mV} / \mathrm{s}\right): E_{1 / 2}=1.17 \mathrm{~V}\{\mathrm{Ru}(\mathrm{III} / \mathrm{II})\}$. Anal. Calcd for $\mathrm{C}_{26} \mathrm{H}_{30} \mathrm{ClF}_{3} \mathrm{~N}_{9} \mathrm{O}_{6} \mathrm{PRuS}$ : C, 38.03; H, 3.68; N 15.35; Found: C, 38.59; H, 3.95; N, 15.29.

$\left\{\left[\boldsymbol{\kappa}^{3}-\mathrm{C}(\mathrm{pz})_{4}\right] \mathrm{Ru}\left[\mathrm{P}(\mathrm{OCH})_{3} \mathrm{CEt}\right](\mathrm{Cl})\left({ }^{\mathbf{1 5}} \mathrm{NH}_{2} \mathrm{Ph}\right)\right\}\{\mathrm{OTf}\} \quad\left({ }^{\mathbf{1 5}} \mathrm{N}-5\right) .{ }^{15} \mathrm{~N}-5$ was prepared following the procedure for $\mathbf{5}$ except that isotopically labeled ${ }^{15} \mathrm{~N}$-aniline was used. ${ }^{1} \mathrm{H}$ NMR spectroscopy $\left(\mathrm{CD}_{2} \mathrm{Cl}_{2}\right)$ confirmed the identity of the product with resonances 
identical to $\mathbf{5}$ except for the amine resonances, which were observed as doublet of doublets at $5.69 \mathrm{ppm}$ and $4.72 \mathrm{ppm}\left(\right.$ each $1 \mathrm{H}$, each a dd, ${ }^{1} J_{\mathrm{NH}}=73 \mathrm{~Hz}$ and ${ }^{2} J_{\mathrm{HH}}=12 \mathrm{~Hz}$ ). $\left\{\left[\boldsymbol{\kappa}^{3}-\mathrm{C}(\mathrm{pz})_{4}\right] \mathbf{R u}\left[\mathbf{P}(\mathbf{O C H})_{3} \mathbf{C E t}\right](\mathrm{Cl})\left(\mathrm{NH}_{2} \mathbf{P h}\right)\right\}\left\{\mathrm{BAr}_{4}{ }_{4}\right\}(6)$. A mixture of 4 (52 mg, $0.064 \mathrm{mmol})$ and $\mathrm{NaBAr}_{4}(57 \mathrm{mg}, 0.064 \mathrm{mmol})$ was stirred in $\sim 5 \mathrm{~mL}$ of methylene chloride at room temperature. After 30 minutes, the solution became cloudy and was filtered through a frit. The yellow filtrate was concentrated to dryness under reduced pressure to yield a yellow solid $(67 \mathrm{mg}, 68 \%) .{ }^{1} \mathrm{H} \mathrm{NMR}\left(\mathrm{CDCl}_{3}, \delta\right): 8.28,8.72,8.17,8.08$, 8.06, 7.95, 5.91, 5.85 (each $1 \mathrm{H}$, each a d, ${ }^{3} J_{\mathrm{HH}}=2 \sim 3 \mathrm{~Hz}$, pz 3 or 5 position), $7.50(4 \mathrm{H}$, br $\mathrm{s}, \mathrm{BAr}_{4}^{\prime}$ para), $7.68\left(8 \mathrm{H}\right.$, br s, $\mathrm{BAr}_{4}^{\prime}$ ortho), $7.08(3 \mathrm{H}, \mathrm{m}$, phenyl meta and para), 6.85, 6.77, 6.63, 6.40 (each $1 \mathrm{H}$, each a dd, ${ }^{3} J_{\mathrm{HH}}=2 \sim 3 \mathrm{~Hz}$, coordinated pz 4 position), $6.69(2 \mathrm{H}$, $\mathrm{d},{ }^{3} J_{\mathrm{HH}}=7 \mathrm{~Hz}$, phenyl ortho $), 5.03\left(1 \mathrm{H}, \mathrm{d},{ }^{2} J_{\mathrm{HH}}=11 \mathrm{~Hz}, \mathrm{PhNH}_{2}\right), 4.50\left(1 \mathrm{H}, \mathrm{d},{ }^{2} J_{\mathrm{HH}}=11\right.$ $\left.\mathrm{Hz}, \mathrm{PhNH} H_{2}\right), 4.43\left(6 \mathrm{H}, \mathrm{d},{ }^{3} J_{\mathrm{PH}}=4.6 \mathrm{~Hz},-\left(\mathrm{OCH}_{2}\right)_{3}\right), 1.32\left(2 \mathrm{H}, \mathrm{q},{ }^{3} J_{\mathrm{HH}}=8 \mathrm{~Hz},-\mathrm{CH}_{2} \mathrm{CH}_{3}\right)$, $0.87\left(3 \mathrm{H}, \mathrm{t},{ }^{3} J_{\mathrm{HH}}=8 \mathrm{~Hz},-\mathrm{CH}_{2} \mathrm{CH}_{3}\right) .{ }^{13} \mathrm{C}\left\{{ }^{1} \mathrm{H}\right\} \mathrm{NMR}\left(\mathrm{THF}-d_{8}, \delta\right): 163.0\left(\mathrm{q},{ }^{1} J_{\mathrm{BC}}=50 \mathrm{~Hz}\right.$, $\mathrm{BAr}_{4}{ }_{4}$ ipso), $153.2,150.6,149.0,146.4,138.8,136.8,133.6,130.4$ (each a s, pz 3 or 5 position), 145.9 (s, phenyl ipso), 136.0, 135.8, 118.4 (eash a s, $\mathrm{BAr}_{4}^{\prime}$ ortho, meta, and para), 129.9, 125.5, 122.1 (each a s, phenyl ortho, meta, and para), 130.8 (s, $\mathrm{BAr}_{4}^{\prime} C-\mathrm{CF}_{3}$ ) $125.7\left(\mathrm{q},{ }^{1} J_{\mathrm{FC}}=272 \mathrm{~Hz}, \mathrm{BAr}^{\prime}{ }_{4}-C_{\mathrm{F}}\right), 112.5,109.9,109.7109 .0$ (each a s, pz 4 position), $95.2\left(\mathrm{~s}, C(\mathrm{pz})_{4}\right), 75.6\left(\mathrm{~s},-\left(\mathrm{OCH}_{2}\right)_{3}\right), 36.7\left(\mathrm{~d},{ }^{3} J_{\mathrm{PC}}=31 \mathrm{~Hz},-\left(\mathrm{OCH}_{2}\right)_{3} C-\right), 24.1(\mathrm{~s},-$ $\left.\mathrm{CH}_{2} \mathrm{CH}_{3}\right), 7.5\left(\mathrm{~s},-\mathrm{CH}_{2} \mathrm{CH}_{3}\right) .{ }^{31} \mathrm{P}\left\{{ }^{1} \mathrm{H}\right\} \mathrm{NMR}\left(\mathrm{CDCl}_{3}, \delta\right): 130.0\left(\mathrm{~s}, P\left(\mathrm{OCH}_{2}\right)_{3} \mathrm{C}-\right) .{ }^{19} \mathrm{~F}$ $\operatorname{NMR}\left(\mathrm{CDCl}_{3}, \delta\right):-62.8\left(\mathrm{~s}, \mathrm{BAr}_{4}^{\prime}\right)$. Anal. Calcd for $\mathrm{C}_{57} \mathrm{H}_{42} \mathrm{BClF}_{24} \mathrm{~N}_{9} \mathrm{O}_{3} \mathrm{PRu}: \mathrm{C}, 44.59 ; \mathrm{H}$, 2.76; N 8.21; Found: C, 44.49; H, 2.74; N, 8.17.

$\left\{\left[\boldsymbol{\kappa}^{\mathbf{3}}-\mathrm{C}(\mathrm{pz})_{4}\right] \mathrm{Ru}\left[\mathrm{P}(\mathrm{OCH})_{3} \mathrm{CEt}\right](\mathrm{Cl})\left({ }^{\mathbf{1 5}} \mathrm{NH}_{2} \mathrm{Ph}\right)\right\}\left\{\mathrm{BAr}^{\prime}{ }_{4}\right\}\left({ }^{\mathbf{1 5}} \mathrm{N}-6\right) .{ }^{15} \mathrm{~N}-6$ was prepared following the procedure for 6 except that isotopically labeled ${ }^{15} \mathrm{~N}-5$ was used. ${ }^{1} \mathrm{H}$ NMR 
spectroscopy (THF- $d_{8}$ ) confirmed the identity of the produce with resonances identical to 6 except for the amine resonances, which were observed as doublet of doublets at 5.77 ppm and $5.53 \mathrm{ppm}$ (each $1 \mathrm{H}$, each a dd, ${ }^{1} J_{\mathrm{NH}}=73 \mathrm{~Hz}$ and ${ }^{2} J_{\mathrm{HH}}=11 \mathrm{~Hz}$ ).

$\left\{\left[\boldsymbol{c}^{3}-\mathbf{C}(\mathbf{p z})_{4}\right] \mathbf{R u}\left\{\mathbf{P}(\mathbf{O C H})_{3} \mathbf{C E t}\right\}\left(\mathbf{P h N H}_{2}\right)_{2}\right\}\{\mathbf{O T f}\}_{2}$ (7). A mixture of 4 (52 mg, 0.064 mmol) and TlOTf (57 mg, $0.064 \mathrm{mmol}$ ) was dissolved in $\sim 5 \mathrm{~mL}$ of tetrahydrofuran. To the mixture was added $100 \mu \mathrm{L}$ of aniline. The mixture was then heated at $90{ }^{\circ} \mathrm{C}$ in a glass pressure tube. After $18 \mathrm{~h}$, the mixture became brownish-yellow and a white precipitate (TlCl) was observed. The mixture was filtered through Celite. The filtrate was concentrated to dryness under reduced pressure. The residue was dissolved in $1 \mathrm{~mL}$ of methylene chloride and filtered through Celite. The pink filtrate was concentrated to dryness under reduced pressure and dissolved in a minimum amount of tetrahydrofuran. Pentane was slowly added to induce precipitation. The grey solid was collected on a fine porosity frit, washed with pentane and dried in vacuo to yield a white solid. (67 mg, 68\%). ${ }^{1} \mathrm{H} \mathrm{NMR}\left(\mathrm{THF}-d_{8}, \delta\right): 8.94\left(1 \mathrm{H}, \mathrm{d},{ }^{3} J_{\mathrm{HH}}=3 \mathrm{~Hz}, \mathrm{pz} 3\right.$ or 5 position $), 8.55\left(1 \mathrm{H}, \mathrm{d},{ }^{3} J_{\mathrm{HH}}=3\right.$ $\mathrm{Hz}, \mathrm{pz} 3$ or 5 position), $8.24\left(1 \mathrm{H}, \mathrm{d},{ }^{3} J_{\mathrm{HH}}=2 \mathrm{~Hz}, \mathrm{pz} 3\right.$ or 5 position $), 7.67\left(2 \mathrm{H}, \mathrm{d},{ }^{3} J_{\mathrm{HH}}=3\right.$ $\mathrm{Hz}$, coordinate 3 or 5 position), $7.59\left(2 \mathrm{H}, \mathrm{d},{ }^{3} J_{\mathrm{HH}}=2 \mathrm{~Hz}\right.$, coordinate 3 or 5 position), 7.22 (1H, bs, pz 3 or 5 position), 7.09 6.95 (4H, m, overlapping phenyl meta, para and pz 4 position), $6.74\left(4 \mathrm{H}, \mathrm{d},{ }^{3} J_{\mathrm{HH}}=7.4 \mathrm{~Hz}\right.$, phenyl ortho $), 6.46(1 \mathrm{H}, \mathrm{bs}$, coordinated pz 4 position $), 6.37\left(2 \mathrm{H}, \mathrm{dd},{ }^{3} J_{\mathrm{HH}}=2.7 \mathrm{~Hz}\right.$, coordinated pz 4 position $), 6.30\left(2 \mathrm{H}, \mathrm{d},{ }^{2} J_{\mathrm{HH}}=12\right.$ $\mathrm{Hz}, \mathrm{PhNH}_{2}$,), $5.98\left(2 \mathrm{H}, \mathrm{d},{ }^{2} J_{\mathrm{HH}}=12 \mathrm{~Hz}, \mathrm{PhNH} H_{2}\right), 4.60\left(6 \mathrm{H}, \mathrm{d},{ }^{3} J_{\mathrm{PH}}=4.5 \mathrm{~Hz},-\left(\mathrm{OCH}_{2}\right)_{3}\right)$, $1.35\left(2 \mathrm{H}, \mathrm{q},{ }^{3} \mathrm{~J}_{\mathrm{HH}}=7.7 \mathrm{~Hz},-\mathrm{CH}_{2} \mathrm{CH}_{3}\right), 0.89\left(3 \mathrm{H}, \mathrm{t},{ }^{3} J_{\mathrm{HH}}=7.7 \mathrm{~Hz},-\mathrm{CH}_{2} \mathrm{CH}_{3}\right) .{ }^{13} \mathrm{C}\left\{{ }^{1} \mathrm{H}\right.$ NMR $\left(\mathrm{CD}_{3} \mathrm{CN}, \delta\right): 150.97,147.44,146.43,142.97,138.76,136.22$ (each a s, pz 3 or 5 position), 135.83 (s, phenyl ipso), 129.94, 125.94, 121.99 (each a s, phenyl ortho, meta, 
and para), 112.59, 109.80, 109.31 (each a s, pz 4 position), $94.06\left(\mathrm{~s}, C(\mathrm{pz})_{4}\right), 75.60$ (s, $\left.\left(\mathrm{OCH}_{2}\right)_{3}\right), 35.55\left(\mathrm{~d},{ }^{3} \mathrm{~J}_{\mathrm{PC}}=32 \mathrm{~Hz},-\left(\mathrm{OCH}_{2}\right)_{3} \mathrm{C}-\right), 23.21\left(\mathrm{~s},-\mathrm{CH}_{2} \mathrm{CH}_{3}\right), 6.94\left(\mathrm{~s},-\mathrm{CH}_{2} \mathrm{CH}_{3}\right)$. ${ }^{31} \mathrm{P}\left\{{ }^{1} \mathrm{H}\right\}$ NMR $\left(\mathrm{CD}_{3} \mathrm{CN}, \delta\right): 133.04\left(\mathrm{~s}, P\left(\mathrm{OCH}_{2}\right){ }_{3} \mathrm{C}-\right) \cdot{ }^{19} \mathrm{~F}$ NMR $\left(\mathrm{CD}_{3} \mathrm{CN}, \delta\right):-80.57$ (s, OTf). Attempts to obtain elemental analysis were not successful.

\section{Attempts to synthesize anilido complexes $\left[\kappa^{3}-\mathrm{C}(\mathrm{pz})_{4}\right] \mathrm{Ru}\left[\mathrm{P}\left(\mathrm{OCH}_{2}\right)_{3} \mathrm{CEt}\right](\mathrm{Cl})(\mathrm{NHPh})$} (8) and $\left[\boldsymbol{\kappa}^{3}-\mathrm{C}(\mathbf{p z})_{4}\right] \mathrm{Ru}\left[\mathrm{P}\left(\mathrm{OCH}_{2}\right)_{3} \mathrm{CEt}\right](\mathrm{NHPh})_{2}$ (9). A screw-cap NMR tube was charged with $10 \mathrm{mg}$ of Ru-aniline complexes $(\mathbf{5}, \mathbf{6}$ or 7$)$ and $0.7 \mathrm{~mL}$ of THF- $d_{8}$. The solution was cooled to $-78{ }^{\circ} \mathrm{C}$ in dry ice/acetone. To this solution was added 1.1 equivalents of base (e.g., sodium bis(trimethylsilyl)amide) based on aniline ligand via a microsyringe. Upon addition of base, an instantaneous color change was observed, from pale yellow to maroon. The solution was allowed to warm to room temperature. The solution was concentrated to dryness under reduced pressure and dissolved in a minimum amount of tetrahydrofuran. Pentane was slowly added to induce precipitation. The resulting solid was collected on a fine porosity frit, washed with pentane and dried in vacuo to yield a dark brown solid. ${ }^{1} \mathrm{H}$ and ${ }^{31} \mathrm{P}$ NMR spectra of the solid in THF- $d_{8}$ indicated decomposition to multiple intractable products.

$\left\{\left[\boldsymbol{\kappa}^{3}-\mathrm{C}(\mathrm{pz})_{4}\right] \mathrm{Ru}\left[\mathrm{P}(\mathrm{OCH})_{3} \mathrm{CEt}\right]\left(\mathrm{CH}_{3} \mathrm{OH}\right)_{2}\right\}(\mathrm{OTf})_{2}(10)$. A screw-cap NMR tube was charged with $4(10 \mathrm{mg}, 0.007 \mathrm{mmol}), \operatorname{AgOTf}(5 \mathrm{mg}, 0.02 \mathrm{mmol})$ and $0.7 \mathrm{~mL}$ of $\mathrm{CH}_{3} \mathrm{OH}$. The solution was heated at $80{ }^{\circ} \mathrm{C}$. After $20 \mathrm{~h}$, a grey precipitate $(\mathrm{AgCl})$ was observed and the solution was filtered through Celite. The yellow filtrate was concentrated to dryness under reduced pressure. The residue was dissolved in $\mathrm{CD}_{3} \mathrm{OD}$. Attempts to obtain a solid were not successful. ${ }^{1} \mathrm{H}$ NMR $\left(\mathrm{CD}_{3} \mathrm{OD}, \delta\right)$ : 9.20, 8.49 (each $1 \mathrm{H}$, each a bs, pz 3 or 5 position), $8.84\left(1 \mathrm{H}, \mathrm{d},{ }^{3} J_{\mathrm{HH}}=3 \mathrm{~Hz}, \mathrm{pz} 3\right.$ or 5 position $), 8.35\left(1 \mathrm{H}, \mathrm{d},{ }^{3} J_{\mathrm{HH}}=2 \mathrm{~Hz}, \mathrm{pz} 3\right.$ or 5 
position), $8.10\left(2 \mathrm{H}, \mathrm{d},{ }^{3} J_{\mathrm{HH}}=2 \mathrm{~Hz}\right.$, coordinated pz 3 or 5 position $), 7.48\left(2 \mathrm{H}, \mathrm{d},{ }^{3} J_{\mathrm{HH}}=3\right.$ $\mathrm{Hz}$, coordinated pz 3 or 5 position), $7.09\left(1 \mathrm{H}, \mathrm{dd},{ }^{3} J_{\mathrm{HH}}=3 \mathrm{~Hz}, \mathrm{pz} 4\right.$ position), $6.96(1 \mathrm{H}$, m, 4 position $), 6.61\left(2 \mathrm{H}, \mathrm{dd},{ }^{3} J_{\mathrm{HH}}=3 \mathrm{~Hz}\right.$, coordinated pz 4 position $), 4.59\left(6 \mathrm{H}, \mathrm{d},{ }^{3} J_{\mathrm{HP}}=5\right.$ $\left.\mathrm{Hz},-\left(\mathrm{OCH}_{2}\right)_{3}\right), 3.47\left(3 \mathrm{H}, \mathrm{s}, \mathrm{CH}_{3} \mathrm{OH}\right), 3.34\left(1 \mathrm{H}, \mathrm{s}, \mathrm{CH}_{3} \mathrm{OH}\right), 1.41\left(2 \mathrm{H}, \mathrm{q},{ }^{3} J_{\mathrm{HH}}=8 \mathrm{~Hz},-\right.$ $\left.\mathrm{CH}_{2} \mathrm{CH}_{3}\right), 0.92\left(3 \mathrm{H}, \mathrm{t},{ }^{3} \mathrm{~J}_{\mathrm{HH}}=8 \mathrm{~Hz},-\mathrm{CH}_{2} \mathrm{CH}_{3}\right) .{ }^{31} \mathrm{P}\left\{{ }^{1} \mathrm{H}\right\} \mathrm{NMR}\left(\mathrm{CD}_{3} \mathrm{OD}, \delta\right): 131.2(\mathrm{~s}$, $\left.P\left(\mathrm{OCH}_{2}\right)_{3} \mathrm{C}-\right)$.

$\left\{\left[\boldsymbol{\kappa}^{3}-\mathbf{C}(\mathbf{p z})_{4}\right] \mathbf{R u}\left[\mathbf{P}(\mathbf{O C H})_{3} \mathbf{C E t}\right]\left(\mathrm{CD}_{3} \mathrm{OD}\right)_{2}\right\}\{\mathrm{OTf}\}_{2} \quad\left(\mathbf{1 0}-\boldsymbol{d}_{8}\right) . \quad 10-d_{8}$ was prepared following the procedure for complex $\mathbf{1 0}$ except that $\mathrm{CD}_{3} \mathrm{OD}$ was used. ${ }^{1} \mathrm{H} \mathrm{NMR}$ spectroscopy $\left(\mathrm{CD}_{3} \mathrm{OD}\right)$ confirmed the identity of the product with resonances identical to 10 except for the methanol ligand resonances, which were ${ }^{1} \mathrm{H}$ NMR silent.

\section{In situ generation of $\left\{\left[\kappa^{3}-\mathrm{C}(\mathrm{pz})_{4}\right] \mathrm{Ru}\left[\mathrm{P}\left(\mathrm{OCH}_{2}\right)_{3} \mathrm{CEt}\right](\mathrm{Cl})\left(\mathrm{H}_{2} \mathrm{O}\right)\right\}\{\mathrm{OTf}\}$ (11). A} screw-cap NMR tube was charged with 4 (10 mg, $0.007 \mathrm{mmol}), \mathrm{H}_{2} \mathrm{O}(50 \mu \mathrm{L})$ and $0.7 \mathrm{~mL}$ of THF- $d_{8}$. The resulting solution was heated at $80{ }^{\circ} \mathrm{C}$. After $20 \mathrm{~h}$, an unsymmetrical product was confirmed by ${ }^{1} \mathrm{H}$ NMR spectroscopy: 9.01, 8.40 (each $1 \mathrm{H}$, each a bs, pz 3 or 5 position), 8.80, 8.30, 8.14, 7.98, 7.35, 7.28 (each $1 \mathrm{H}$, each a d, ${ }^{3} J_{H H}=2 \sim 3 \mathrm{~Hz}, \mathrm{pz} 3$ or 5 position), 7.10, 6.76, 6.54, 6.41 (each $1 \mathrm{H}$, each a dd, ${ }^{3} J_{\mathrm{HH}}=3 \mathrm{~Hz}$, pz 4 position). $4.42(6 \mathrm{H}$, $\left.\mathrm{d},{ }^{3} J_{\mathrm{PH}}=5 \mathrm{~Hz},-\left(\mathrm{OCH}_{2}\right)_{3}\right), 1.32\left(2 \mathrm{H}, \mathrm{q},{ }^{3} \mathrm{~J}_{\mathrm{HH}}=8 \mathrm{~Hz},-\mathrm{CH}_{2} \mathrm{CH}_{3}\right), 0.85\left(3 \mathrm{H}, \mathrm{t},{ }^{3} \mathrm{~J}_{\mathrm{HH}}=8 \mathrm{~Hz}\right.$, $\left.-\mathrm{CH}_{2} \mathrm{CH}_{3}\right)$. 


\section{References}

(1)Lewis, N. S.; Nocera, D. G. Proc. Natl. Acad. Sci. 2006, 103, 15729.

(2)"The Future of Natural Gas: An Interdisciplinary MIT Study," M.I.T., 2011.

(3)Olah, G. A.; Molnar, A. Hydrocarbon Chemistry; John Wiley \& Sons, Inc.: New York, 1995.

(4)Lin, M.; Hogan, T.; Sen, A. J. Am. Chem. Soc. 1997, 119, 6048.

(5)Shilov, A. E.; Shul'pin, G. B. Chem. Rev. 1997, 97, 2879.

(6)Periana, R. A.; Bhalla, G.; Tenn III, W. J.; Young, K. J. H.; Liu, X. Y.; Mironov, O.; Jones, C. J.; Ziatdinov, V. R. J. Mol. Cat. A: Chem. 2004, $220,7$.

(7)Conley, B. L.; Tenn III, W. J.; Young, K. J. H.; Ganesh, S. K.; Meier, S. K.; Ziatdinov, V. R.; Mironov, O.; Oxgaard, J.; Gonzales, J.; Goddard III, W. A.; Periana, R. A. J. Mol. Cat. A: Chem. 2006, 251, 8 .

(8)Crabtree, R. H. J. Chem. Soc., Dalton Trans. 2001, 2437.

(9)Labinger, J. A.; Bercaw, J. E. Nature 2002, 417, 507.

(10) Blanksby, S. J.; Ellison, G. B. Acc. Chem. Res. 2003, 36, 255.

(11) Lin, M. R.; Sen, A. M. J. Chem. Soc., Chem. Commun. 1992, 892.

(12) Sironi, M.; Cooper, D. L.; Gerratt, J.; Raimondi, M. J. Am. Chem. Soc. 1990, $112,5054$.

(13) Basickes, N.; Hogan, T. E.; Sen, A. J. Am. Chem. Soc. 1996, 118, 13111.

(14) Mukhopadhyay, S.; Bell, A. T. Chem. Commun. 2003, 1590.

(15) Zerella, M.; Mukhopadhyay, S.; Bell, A. T. Org. Lett. 2003, 5, 3193.

(16) Mukhopadhyay, S.; Bell, A. T. J. Mol. Catal. A: Chem. 2004, 211, 59.

(17) Lin, M.; Sen, A. Nature 1994, 368, 613.

(18) Gesser, H. D.; Hunter, N. R. Catal. Today 1998, 42, 183.

(19) Lunsford, J. H. Catal. Today 2000, 63, 165.

(20) Periana, R. A.; Mirinov, O.; Taube, D. J.; Gamble, S. Chem. Commun. 2002, 2376.

(21) Mukhopadhyay, S.; Zerella, M.; Bell, A. T. Adv. Synth. Catal. 2005, 347, 1203.

(22) Colby, J.; Stirling, D. I.; Dalton, H. Biochem. J 1977, 165, 395.

(23) Kung, H. H. Transition Metal Oxides; Elsevier: Amsterdam, 1989.

(24) Palkovits, R.; Antonietti, M.; Kuhn, P.; Thomas, A.; Schuth, F. Angew. Chem. Int. Ed. 2009, 48, 6909.

(25) Wolf, D. Angew. Chem. Int. Ed. 1998, 24, 3351.

(26) Otsuka, K.; Wang, Y. Appl. Catal. A: Gen 2001, 222, 145.

(27) Walker, G. S.; Lapszewicz, J. A.; Foulds, G. A. Catal. Today 1994, 21, 519.

(28) Burch, R.; Squire, G. D.; Tsang, S. C. Journal of the Chemical Society, Faraday Transactions 1: Physical Chemistry in Condensed Phases 1989, 85, 3561.

(29) Lunsford, J. H. Angew. Chem. Int. Ed. Engl. 1995, 34, 970.

(30) Anderson, L. C.; Xu, M.; Mooney, C. E.; Rosynek, M. P.; Lunsford, J. H. J. Am. Chem. Soc. 1993, 115, 6322.

(31) Tong, Y.; Lunsford, J. H. J. Am. Chem. Soc. 1991, 113, 4741.

(32) Otsuka, K.; Wang, Y.; Yamanaka, I.; Morikawa, A. J. Chem. Soc., Faraday Trans. 1993, 89, 4225. 
(33) Mizuno, N.; Tateishi, M.; Iwamoto, M. Appl. Catal. A: Gen. 1995, 128, L165.

(34) Michalakos, P. M.; Birkeland, K.; Kung, H. H. J. Catal. 1996, 158, 349.

(35) Mizuno, N.; Ishige, H.; Seki, Y.; Misono, M.; Suh, D. J.; Han, W.; Kudo, T. Chem. Commun. 1997, 1295.

(36) Bar-Nahum, I.; Khenkin, A. M.; Neumann, R. J. Am. Chem. Soc. 2004, 126, 10236.

(37) Hammond, C.; Forde, M. M.; Ab Rahim, M. H.; Thetford, A.; He, Q.; Jenkins, R. L.; Dimitratos, N.; Lopez-Sanchez, J. A.; Dummer, N. F.; Murphy, D. M.; Carley, A. F.; Taylor, S. H.; Willock, D. J.; Stangland, E. E.; Kang, J.; Hagen, H.; Kiely, C. J.; Hutchings, G. J. Angew. Chem. Int. Ed. 2012, 51, 5129.

(38) Etard, A. Ann. Chim. Phys. 1881, 22, 218.

(39) Fenton, H. J. H. J. Chem. Soc. 1894, 65, 899.

(40) Fenton, H. J. H. Proc. Chem. Soc. 1899, 15, 224.

(41) Shilov, A. E.; Shulpin, G. B. Russ. Chem. Rev. 1987, 56, 442.

(42) Kao, L. C.; Hutson, A. C.; Sen, A. J. Am. Chem. Soc. 1991, 113, 700.

(43) Muehlhofer, M.; Strassner, T.; Herrmann, W. A. Angew. Chem. Int. Ed. 2002, 41,1745 .

(44) Periana, R. A.; Taube, D. J.; Evitt, E. R.; Loffler, D. G.; Wentrcek, P. R.; Voss, G.; Masuda, T. Science 1993, 259, 340.

(45) Periana, R. A.; Taube, D. J.; Gamble, S.; Taube, H.; Satoh, T.; Fuji, H. Science 1998, 280, 5650 .

(46) Jones, C. J.; Taube, D.; Ziatdinov, V. R.; Periana, R. A.; Nielson, R. J.; Oxgaard, J.; Goddard III, W. A. Angew. Chem. Int. Ed. 2004, 43, 4626.

(47) Nishiguchi, T.; Nakata, K.; Takaki, K.; Fujiwara, Y. Chem. Lett. 1992, 21, 1141.

(48) Asadullah, M.; Kitamura, T.; Fujiwara, Y. Angew. Chem. Int. Ed. 2000, 39, 2475.

(49) Lin, M. R.; Hogan, T. E.; Sen, A. J. Am. Chem. Soc. 1996, 118, 4574.

(50) Forster, D. Adv. Organomet. Chem. 1979, 17, 255.

(51) Fulton, J. R.; Sklenak, S.; Bouwkamp, M. W.; Bergman, R. G. J. Am. Chem. Soc. 2002, 124, 4722 .

(52) Fulton, J. R.; Bouwkamp, M. W.; Bergman, R. G. J. Am. Chem. Soc. 2000, 122, 8799.

(53) Holland, A. W.; Bergman, R. G. J. Am. Chem. Soc. 2002, 124, 14684.

(54) Fox, D. J.; Bergman, R. G. Organometallics 2004, 23, 1656.

(55) Conner, D.; Jayaprakash, K. N.; Gunnoe, T. B.; Boyle, P. D. Inorg. Chem. 2002, 41,3042 .

(56) Conner, D.; Jayaprakash, K. N.; Wells, M. B.; Manzer, S.; Gunnoe, T. B.; Boyle, P. D. Inorg. Chem. 2003, 42, 4759.

(57) Jayaprakash, K. N.; Conner, D.; Gunnoe, T. B. Organometallics 2001, 20, 5254.

(58) Gunnoe, T. B. Eur. J. Inorg. Chem. 2007, 1185.

(59) Jonas, R. T.; Stack, T. D. P. J. Am. Chem. Soc. 1997, 119, 8566.

(60) Mayer, J. M. Acc. Chem. Res. 1998, 31, 441.

(61) Bryant, J. R.; Taves, J. E.; Mayer, J. M. Inorg. Chem. 2002, 41, 2769.

(62) Larsen, A. S.; Wang, K.; Lockwood, M. A.; Rice, G. L.; Won, T.-J.; Lovell, S.; Sadílek, M.; Turecek, F.; Mayer, J. M. J. Am. Chem. Soc. 2002, 124, 10112. 
(63) Feng, Y.; Gunnoe, T. B.; Grimes, T. V.; Cundari, T. R. Organometallics 2006, $25,5456$.

(64) Goldsmith, C. R.; Jonas, R. T.; Stack, T. D. P. J. Am. Chem. Soc. 2002, 124, 83.

(65) Chen, M. S.; White, M. C. Science 2007, 318, 783.

(66) Theopold, K. H.; Gunay, A. Chem. Rev. 2010, 110, 1060.

(67) Feng, Y.; Lail, M.; Barakat, K. A.; Cundari, T. R.; Gunnoe, T. B.; Petersen, J. L. J. Am. Chem. Soc. 2005, 127, 14174.

(68) Feng, Y.; Lail, M.; Foley, N. A.; Gunnoe, T. B.; Barakat, K. A.; Cundari, T. R.; Petersen, J. L. J. Am. Chem. Soc. 2006, 128, 7982.

(69) Tenn III, W. J.; Young, K. J. H.; Bhalla, G.; Oxgaard, J.; Goddard III, W. A.; Periana, R. A. J. Am. Chem. Soc. 2005, 127, 14172.

(70) Tenn III, W. J.; Young, K. J. H.; Oxgaard, J.; Nielson, R. J.; Goddard III, W. A.; Periana, R. A. Organometallics 2006, 25, 5173.

(71) Oxgaard, J.; Tenn III, W. J.; Nielson, R. J.; Periana, R. A.; Goddard III, W. A. Organometallics 2007, 26, 1565.

(72) Kloek, S. M.; Heinekey, D. M.; Goldberg, K. I. Angew. Chem. Int. Ed. 2007, 46, 4736.

(73) Conner, D.; Jayaprakash, K. N.; Cundari, T. R.; Gunnoe, T. B. Organometallics 2004, 23, 2724.

(74) Cundari, T. R.; Grimes, T. V.; Gunnoe, T. B. J. Am. Chem. Soc. 2007, 129, 13172.

(75) Lersch, M.; Tilset, M. Chem. Rev. 2005, 105, 2471.

(76) Stahl, S. S.; Labinger, J. A.; Bercaw, J. E. Angew. Chem. Int. Ed. 1998, 37, 2180.

(77) Kreutz, J. E.; Shukhaev, A.; Du, W. B.; Druskin, S.; Daugulis, O.; Ismagilov, R. F. J. Am. Chem. Soc. 2010, 132, 3128.

(78) Cummins, C. C.; Baxter, S. M.; Wolczanski, P. T. J. Am. Chem. Soc. 1988, 110, 8731.

(79) Walsh, P. J.; Hollander, F. J.; Bergman, R. G. J. Am. Chem. Soc. 1988, 110, 8729.

(80) de With, J. D.; Horton, A. D. Angew. Chem. Int. Ed. Engl. 1993, 32, 903.

(81) Schaller, C. P.; Wolczanski, P. T. Inorg. Chem. 1993, 32, 131.

(82) Nugent, W. A.; Haymore, B. L. Coord. Chem. Rev. 1980, 31, 123.

(83) Cundari, T. R. J. Am. Chem. Soc. 1992, 114, 10557.

(84) Slaughter, L. M.; Wolczanski, P. T.; Klinckman, T. R.; Cundari, T. R. J. Am. Chem. Soc. 2000, 122, 7953.

(85) Cundari, T. R.; Klinckman, T. R.; Wolczanski, P. T. J. Am. Chem. Soc. 2002, 124,1481 .

(86) Hartwig, J. F. Angew. Chem. Int. Ed. 1998, 37, 2046.

(87) Wolfe, J. P.; Wagaw, S.; Marcoux, J.-F.; Buchwald, S. L. Acc. Chem. Res. 1998, 31,805 .

(88) Hartwig, J. F. In Modern Amination Methods; Ricci, A., Ed.; Wiley-VCH: Weinheim, 2000; pp 195.

(89) Mayer, J. M. Comments Inorg. Chem. 1988, 8, 125.

(90) Caulton, K. G. New J. Chem. 1994, 18, 25. 
(91) Fulton, J. R.; Holland, A. W.; Fox, D. J.; Bergman, R. G. Acc. Chem. Res. 2002, $35,44$.

(92) Kaplan, A. W.; Ritter, J. C. M.; Bergman, R. G. J. Am. Chem. Soc. 1998, 120, 6828.

(93) Fryzuk, M. D.; Montgomery, C. D.; Rettig, S. J. Organometallics 1991, 10, 467.

(94) Abdur-Rashid, K.; Faatz, M.; Lough, A. J.; Morris, R. H. J. Am. Chem. Soc. 2001, 123, 7473 .

(95) Hanson, S. K.; Heinekey, D. M.; Goldberg, K. I. Organometallics 2008, 27, 1454.

(96) Webb, J. R.; Pierpont, A. W.; Munro-Leighton, C.; Gunnoe, T. B.; Cundari, T. R.; Boyle, P. D. J. Am. Chem. Soc. 2010, 132, 4520.

(97) Fulmer, G. R.; Muller, R. P.; Kemp, R. A.; Goldberg, K. I. J. Am. Chem. Soc. 2009, 131, 1346.

(98) Lail, M.; Bell, C. M.; Conner, D.; Cundari, T. R.; Gunnoe, T. B.; Petersen, J. L. Organometallics 2004, 23, 5007.

(99) Foley, N. A.; Lail, M.; Lee, J. P.; Gunnoe, T. B.; Cundari, T. R.; Petersen, J. L. J. Am. Chem. Soc. 2007, 129, 6765.

(100) Ess, D. H.; Gunnoe, T. B.; Cundari, T. R.; Goddard III, W. A.; Periana, R. A. Organometallics 2010, 29, 6801.

(101) Rachidi, I. E.-I.; Eisenstein, O.; Jean, Y. New J. Chem. 1990, 14, 671.

(102) Riehl, J. F.; Jean, Y.; Eisenstein, O.; Pelissier, M. Organometallics 1992, 11, 729.

(103) Davy, R. D.; Hall, M. B. Inorg. Chem. 1989, 28, 3524.

(104) Julia, S.; Del, M. J. M.; Avila, L.; Elguero, J. Org. Prep. Proced. Int. 1984, 16, 299.

(105) Bordwell, F. G.; Algrim, D.; Vanier, N. R. J. Org. Chem. 1977, 42, 1817.

(106) Rappoport, Z. CRC Handbook of Tables for Organic Compound Identification; 3rd ed.; CRC Press: Boca Raton, FL, 1984.

(107) Ballinger, P.; Long, F. A. J. Am. Chem. Soc. 1960, 82, 795.

(108) Bercaw, J. E.; Hazari, N.; Labinger, J. A. Organometallics 2009, 28, 5489.

(109) Williams, T. J.; Caffyn, A. J. M.; Hazari, N.; Oblad, P. F.; Labinger, J. A.; Bercaw, J. E. J. Am. Chem. Soc. 2008, 130, 2418.

(110) Bercaw, J. E.; Hazari, N.; Labinger, J. A.; Oblad, P. E. Angew. Chem. Int. Ed. 2008, 47, 9941.

(111) Woerpel, K. A.; Bergman, R. G. J. Am. Chem. Soc. 1993, 115, 7888.

(112) Hartwig, J. F.; Bergman, R. G.; Andersen, R. A. J. Am. Chem. Soc. 1991, 113, 6499.

(113) Burn, M. J.; Fickes, M. G.; Hartwig, J. F.; Hollander, F. J.; Bergman, R. G. J. Am. Chem. Soc. 1993, 115, 5875.

(114) Burn, M. J.; Fickes, M. G.; Hollander, F. J.; Bergman, R. G. Organometallics 1995, 14, 137.

(115) Evans, I. P.; Spencer, A.; Wilkinson, G. J. Chem. Soc., Dalton Trans. 1973, 204.

(116) Yakelis, N. A.; Bergman, R. G. Organometallics 2005, 24, 3579.

(117) Hallman, P. S. Inorg. Synth. 1970, 12, 237. 